\title{
2 The Sermones (Satires): Preparing for the Future as a Political Commentator
}

\subsection{Introduction to the Chapter}

Horace wrote two collections of Sermones, the name he gave his poems which are generally known as Satires. ${ }^{51}$ Book 1 of the Sermones is his debut. It is generally held that he began writing the book in 42 or 41 B.C. (although I will argue below that 38 B.C. is more likely), and that this was probably released in 36 or 35 B.C. Book 2 appeared five years later..$^{52}$ He wrote the Epodi, and some of the Carmina and Epistulae, in the same period. In this monograph I will focus on the first book of Sermones (S.1). However, I will briefly consider in section 3.3 the political issues he raised in the second book of Sermones (S.2) and in two other genres he wrote in the period of 38 B.C until 30 B.C., the Epodi and a number of Carmina.

The name of Sermones is a more appropriate representation of Horace's intentions than the name of Satires. I suggest that Horace wrote in $S .1$ a lot about satire, but that it is not satiric blame poetry levelled directly at an audience: adapting the words of Schlegel $(2005,6)$ "he presents the bite [in S.1], but does not do the biting." The view that Horace in S.1 didn't write much satiric poetry is contrary to that of Freudenburg in 1993, where he presents Horace as “the satirist," but conforms Freudenburg's view in 2001. For example, he $(2001,7)$ makes the point that S.1.1-1.3 fail to bear evidence of satiric poetry: "But neither is he [Horace] much of a satirist." 53

I will interpret $S .1$ from a functional point of view, and I intend to show that Horace's main purpose in writing $S .1$ is to show that he is and intends to remain a trustworthy member of the circle of Maecenas. Hence, the title of this monograph: Horace's Sermones Book 1: Credentials for Maecenas. Thus, when Horace explored, particularly in S.1.1-1.4, in S.1.6 and in S.1.10, the most effective way of presenting his message, he also depicted, both openly and by allusion, a well-considered view on

51 For Horace's poetry in general, see: Von Albrecht (1997, 565-587); Fraenkel (2002); Rudd (1993b). For his Sermones, see: Brown (2007); Freudenburg (2001, 15-124; 2010); Gowers (2003; 2005; 2012); Griffin (1993); Kiessling (1886/1959); Lefèvre (1993, 37-60; 85-111); Lyne (1995, 21-26); Muecke (1993; 2007); Oliensis (1998, 17-63); Rudd (2007). For the different literary influences on Horace's Sermones, see: Barchiesi (2001); Ferriss-Hill (2015); Freudenburg (1993, 103-108); Harrison (2015); Muecke (2005); West (1974, 22); Zetzel (2006, 38-52). For the names Sermones/Satires, see Freudenburg (2001, 2); Gowers (2005, 48-49; 2012, 12-15).

52 For the dating of the Sermones, see Gowers (2003, 59; 2012, 1-5) (book 1); Freudenburg (2001, xii) and Muecke (1993, 1-2) (books 1 and 2).

53 The suggestion that Horace in $S .1$ is not much of a satirist is contrary to Oliensis $(1998,17-41)$, who $(1998,20)$ writes for example "that Horace's satiric eye, so sharp to see the failings of the man in the crowd, etc.."

O Open Access. () 2019 Leendert Weeda, published by Sciendo. (cc) Br-NC-ND This work is licensed under the Creative Commons Attribution-NonCommercial-NoDerivs 4.0 License.

https://doi.org/10.2478/9783110642636-003 
specific contemporary social and political evils which were in evidence in definite groups of Roman society. He identified those distinct social groups not only to determine the poetic genre he would use and the style that would be most suitable for his future role as political observer, but also to demonstrate to Maecenas that he did not adhere to the views or support the actions of a number of those groups, for example the Stoics or worse: the new rich. After all, he was himself a freedman's son who had achieved some financial independence, but who did not share their cultural views. His commentary on the conduct of those groups is often misinterpreted as satire. When he writes about the character of satire, for example about Lucilius' poetry, it is neither because he sees himself as a successor to Lucilius as a satirist nor because he explores whether satire is the right genre for his commentary. I interpret those lines as part of his main purpose, that is that he gives thought to the manner in which to deliver his message. Further, he prepares himself and his audience within the circle of Maecenas for his future role as political observer and commentator. In other words, his search for his poetic orientation was not the focus of S.1; the most important focus was his self-presentation. ${ }^{54}$ There is also a gradual shift in focus; in S.1.1-1.4 the emphasis is on self-presentation in order to become an acceptable member of the circle of Maecenas, in the later sermones (S.1.5 and S.1.7-1.9) the poet operates as one who sees the desired goal within reach. Lefèvre (1993, 85-111) gave his chapter on S.1 the appropriate name of Selbstfindung: Das erste Satiren-Buch (Finding himself: the first book of Satires). Both the discussion about his views on socio-political issues and his self-presentation are not public ones, as he regularly asserts, but it takes place with his associates of the circle of Maecenas. This also explains his choice of the name Sermones (Conversations or Discussions). Consequently, contrary to common practice I use the latter name in this book. I will also examine Horace's relationship with his associates not only in the present section below, but also in the analyses of many of the individual poems of S.1. As a result of my assumption of the purpose of writing S.1, I suggest that Horace started the writing of the majority of the sermones of the first book most likely from 38 B.C., the year that he was admitted to Maecenas' group. I will argue below that his membership of this group was not a matter of course. A few years before he was invited to join the group, he fought at Philippi on the losing side with Brutus. In addition, his social background was not impressive.

Horace does not only set out his theory and programme of writing in book 1 of the Sermones, but he also gives some initial political commentary. I will review Horace's views on the genre of satire - which in his case I rather call commentary writing with the aid of the extensive scholarly literature that considers Horace's poetry within the literary frame..$^{55} \mathrm{I}$ intend to add to the discussion about the poetic nature

54 For Horace's self-presentation in the Sermones, see also Harrison (2007c).

55 For Horace's views on the satiric genre and the influences of his predecessors, see Anderson (1982, 14-27); DuQuesnay (1984); Freudenburg (1993; 2001, 1-51; 2005b, 7-11; 2010, 273-276); Gowers 
an examination of his political objectives within the functional frame. His political views become apparent by examining the social and political issues he raises, often only briefly or by allusion. When Horace presents his critical commentary on political issues, I note that he makes a distinction between several social and political groups he describes. I will identify those by distinguishing four groups, that is Maecenas' circle and his friends, the political elite, the new classes of nouveau riche in Rome (like the pushy fellow of S.1.9), and the Roman populace.

The nature of Horace's poems in S.1, and his relationship to Ennius (239-169 B.C.) and Lucilius (180 - ab.102 B.C.), the first Roman poets to write satire, and other predecessors is much discussed. ${ }^{56}$ Originally, the genre that later developed into satire drew from a variety of, among others, Hellenistic genres with differing subject matters and meters. Quintilian saw the genre of satire as being typically Roman, so much so that he began his section on Satire in the Institutio Oratoria (10.1.93) with the famous lines Satura quidem tota nostra est (Satire, indeed, is entirely ours). ${ }^{57}$ Quintilian points out already that Horace is special in being less caustic and vindictive, and recognized the unsatirical character of the latter's Sermones. He places Horace firmly within the group of Latin satirists like Lucilius and Persius. He says in Inst.10.1.94: Nam et eruditio in eo mira et libertas atque inde acerbitas et abunde salis. Multum est tersior ac purus magis Horatius et, nisi labor eius amore, praecipuus (For he [Lucilius] has an extraordinary learning and candor, and hence satirical severity and an abundance of wit. Horace is much more correct and purer of style, and he is special, unless I am mistaken by my love for him). Much later, the nineteenth century scholar Kiessling wrote in his commentary:

Der Satiriker Horaz ist kein ergrimmter Kämpfer wie Lucilius, der in heiligem Eifer mit den Waffen verletzenden Spottes oder beißenden Witzes seinen Gegner zu vernichten trachtet: er [Horace] ist kein strafender Richter der einen Delinquenten vor sein Tribunal zieht und unbarmherzig züchtigt, kein Prediger, der dem Sünder zu Herzen und ins Gewissen redet: er ist vielmehr der menschenkundige philosophische Beobachter (The satirist Horace is not an angry fighter as Lucilius was, who in holy fire using the weapon of hurting derision or caustic mockery tries to demolish his opponent: he [Horace] is not a punishing judge, who drags a culprit before his court and merciless chastises him, not a preacher, who appeals to a sinner's heart and conscience; he [Horace] is much more the philosophical observer with insight into human character). ${ }^{58}$

I mention above that my working assumption is that Horace's S.1 displays some of his views on contemporary political issues, but that the focus is on self-presentation and marking out his role as a political observer and commentator. Yet, at this point, I

(2005; 2012, 6-14); Muecke (2005); Oliensis (1998, 17-63); Rudd (2007, 86-131); Schlegel (2010).

56 For Roman satire before Horace, see Muecke (2005); see also my discussion at S.1.4.1-2 in section 2.2.2, and that of S.1.10 in section 2.2.5. For general scholarly literature, see note 51.

57 Winterbottom $(1970,586)$.

58 See Kiessling (1886/1959, xiii). Translation is mine. 
will review the opinions in the scholarly literature on the political context of Horace's "satirical" poetry. Within the context of this book the question whether he wrote about socio-political issues in $S .1$ is closely related to that whether he wrote political satire or not, as $S .1$ is considered satirical poetry by many. However, political satire is one of many appearances of political commentary. Horace also wrote political commentary in other genres such as the Carmina, Epodi, or Epistulae. The reverse is also possible, that is to write satiric poetry about issues that are not related to politics, such as loveaffairs or the literary qualities of comedy. Although Heinze recognised in the 1959 edition of the commentary (Kiessling/Heinze, 1959, xiv) to some extent the political content of the poems, he did not interpret the Sermones as political poems. Sallmann $(1974,186)$ argues that neither in the first nor in the second book of Sermones many examples "einer politischen Satire" can be found. He states that "Politik war ein Gebiet, das Horaz den Oden vorbehielt" (Politics was a domain that Horace reserved for the Carmina). According to Muecke, DuQuesnay (1984) was the first modern scholar to challenge the prevailing view that the Sermones were apolitical. ${ }^{59}$ I agree with Muecke's point that $S .1$ is without question a book with a political content, although in S.1 Horace's direct censuring of political evil in Roman society is limited. Gowers $(2012,4)$ states about the latter point that "the part H.[orace] allows for contemporary politics in Satire I is ostensibly small." I will argue that the obvious political content of S.1 should not be read primarily as satire, but as his self-presentation. Poems in which he addresses directly political issues presenting his critical commentary also appear in the Epodi, and later in the Carmina and Epistulae. I postulated already in section 1.1 that $S .1$ is Horace's way-maker for his future role as political commentator, as his objective in writing $S .1$ is to establish his reliability as a member of Maecenas' circle. Harrison (2015) demonstrates in his essay about "Horace's poetic career" that from S.1 up to and including the Epistulae "we find the Horatian literary career paralleling his socio-political positioning” (Harrison, 2015, 44). He $(2015,45)$ states about the first and formative phase of Horace's poetic career, that is roughly the period until Actium in which he wrote S.1, S.2, Epod. and some Carmina, that this phase

is marked by a rhetoric of literary and socio-political ascent. Horace rises from the humble exponent of rough Lucilian satire, refining it in Callimachean terms, through Archilochean iambus [Epod], tempered for new times, to the brink of lyric operations, matching the movement from Republican defeat at Philippi and loss of property to the generous patronage of Maecenas and political engagement with the interests of the young Caesar.

Harrison writes here about $S .1$ on which I focus in this chapter, and about the Epodes which I briefly discuss in section 3.3. I will also discuss in section 3.3 the political content of some poems of Carm.1 which Horace wrote before 30 B.C. Harrison

59 Muecke (2007, 115-120). She discusses the views of DuQuesnay (1984) and of Freudenburg (2001, 71-124). See also Bond (2009, 138-142). 
(2015, 46-52) also considers the match of Horace's poetic ascent and his sociopolitical stance in Carm.1-3 and Ep.1. For example, he $(2015,48)$ mentions the poet's "quieter approach to both metre and subject matter: a set of poems in which moral philosophy is prominent" in Carm.2, and as the latter "comes to a close, it shows some anticipation of the national and grave themes of the Roman Odes at the beginning of [Carm.] Book 3: in particular 2.18, with its criticism of luxury.” Next, Harrison (2015, 52-58) discusses the political meaning of Horace's later work written in the last ten years of his life, between 17 and 8 B.C., the celebratory Carmen Saeculare and Carm. 4 with its nationalistic themes of Roman military achievements. Concerning the poet's career, Harrison $(2015,55)$ sees that in Carm.4 "the main emphasis [...] is undoubtedly that on the mature poet at the zenith of his career who has established himself in a public and national role." Finally, Horace in his last three poems, Ep.2.1, Ep.2.2, and Ars Poetica, looks back on a distinguished career "who combines proud self-elevation [...] with a beguiling touch of self-deprecation" (Harrison, 2015, 58).

It is apparent from what I wrote in section 1.4 that I differ from Harrison's view on the relationship between Horace and Maecenas, which I see as one of amicitia and not one of "generous patronage," and that I recognize the poet's independent and critical posture with respect to the interests of Octavian. Nevertheless, I regard Harrison's views about Horace's poetic career and his socio-political positioning as consistent with my working assumption that he wrote $S .1$ as credentials for Maecenas: a preparatory step in his career as a future political commentator establishing himself in a national role. He bore out the latter role in his poems in different genres beginning with the Epodi and maintaining the role until the end of his life. Horace emphasizes in both S.1 and the Epodi that he writes for an audience of friends: Maecenas and his associates. This is apparent from the opening lines of Sermones book 1 and the Epodi when he addresses Maecenas in both cases by name. We will also see that he speaks warmly about his associates and about being accepted by Maecenas and the members of his circle in quite a few of the individual sermones (in S.1.3-1.7, S.1.9 and S.1.10). In this book, I will not discuss in detail Horace's poetic development and choices; this has been done amply in the scholarly literature, for example by Freudenburg (1993) and Harrison (2015). I present briefly some aspects of Horace's poetic choices when relevant for the purpose of this study, for instance when I discuss S.1.3.29-34 and the opening of S.1.4. Yet, at this stage it is appropriate to say a few words about the place of Greek iambus in and its influence on Horace's books of Sermones and the book of Epodi. Freudenburg (1993, 103-104) states that "Horace is a writer of iambs, both in his Epodes, which fit the metrical qualification, and in the Satires [i.e. Sermones], which do not. As a satirist [i.e. the author of $S .1$ and $S .2$ ], he could quite reasonably consider himself as writing in the same tradition as the great writers of Greek iambic poetry." In my view, Horace recognized the qualities of the iambus for his own purposes, and thus he chose the iambic genre for his self presentation in S.1, and for the Epodi, his training in the role as a political commentator (for examples of political epodi, see section 3.3). The iambus was a good literary choice for delivering critical poetry about 
norms in society and socio-political issues in S.1 and the Epodi; this is in accordance with Heyworth $(2001,130)$, who points out that elements of archaic Greek iambus were among other things "the use of anecdote," "passion in friendship and enmity," and "frankness of expression (especially in sexual matters)." Horace himself addresses the nature of the iambus in Ars.79-82, and "clearly defines iamb" (Barchiesi, 2001, 143147). He refers undeniably in three places in his oeuvre to Archilochus and Hipponax as poets of invective iambic verse and as sources of inspiration. The reference to both Archilochus and Hipponax is found in Epod.6.11-14, and to Archilochus only in Ep.1.19.23-25 and Ars.79. Mankin $(2010,96)$ states that the ancient Greek iambus

was, in essence, "blame poetry" that in various ways and with varying degrees of hos-tility found fault with conduct that was considered inappropriate or dangerous. The sense of what merited blame was determined not so much by the individual iambist's personal experience and sensibilities as by the norms of his society or social group.

However, Horace's inspiration by Archilochus, Hipponax and successors like Callimachus was not only a literary preference to the iambic, but this also represents two functional choices meant to achieve what he considered the right manner of addressing an audience of friends. The first functional choice lies in the nature of the genre iambus in ancient Greek poetry. The Greek iambus of the seventh and sixth centuries B.C. as practised by Archilochus, Hipponax and others goes back to old Greek cult songs. Mankin points out that iambus in archaic Greece was written among

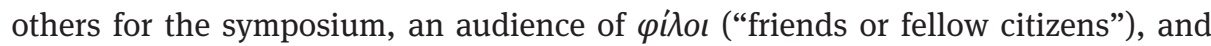

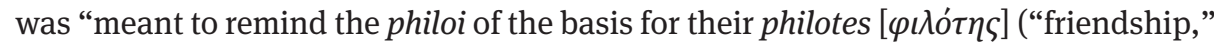
"fellowship") by calling attention to and blaming what might be perceived as threats to the customs, institutions, and modes of conduct that united them as an audience" (Mankin, 2010, 96). For Horace, his amicus Maecenas and the latter's circle of $\varphi$ íloı, many of whom he mentions in the closing lines of S.1.10, were his audience for both S.1 and the Epodi.

Horace had a second reason to choose the iambic genre; this choice is related to what Watson (2003, 18-19) describes as "the manifest sympathy of Maecenas for the novi poetae. The fragments which survive of his [Maecenas'] poetry, albeit scanty, give clear evidence of this.” Hierche (1974, 155; note 41) already recorded Maecenas' sympathy for Catullus. He states "dans le premier groupe [i.e. les épodes qui s'adressent à Mécène 1, 9, 14], les réminiscences de Catulle sont certainement provoquées par le goût que Mécène manifestait pour sa poésie [i.e. de Catulle]” ("In the first group [i.e. the epodi 1, 9, and 14 addressing Maecenas], the allusions to Catullus have certainly been brought about by the predilection that Maecenas showed for his (Catullus') poetry"). In order to understand Maecenas' sympathy, we must consider at this stage the iambic poems of Catullus. Heyworth (2001, 130135) analyses the above-mentioned elements from archaic Greek iambus in Catullian poems. These elements can also be found in S.1 and the Epodi. I single out one of 
the elements, namely "the use of anecdotes," that Heyworth (2001, 131) instances in Horatian poems "as teasing identification of the poet and his target," such as in Epod.4, where "he attacks the freedman who has risen to the rank of tribunus militum and now parades along the Via Sacra," the opening of S.1.9, where Horace himself strolls along the same way when he comes across the "bore," and Canidia and her witchcraft in S.1.8, Epod.5 and 17. Watson (2003, 17-19), writing about the Epodi, also addresses the convergence of Catullus' and Horace's work by evaluating the influence of Neotericism and the poetae novi in the Epodi: in my view his conclusions also hold for S.1. Watson quotes several scholars, of whom the first one is Gagliardi $(1971,61)$ who argues "that Neotericism is the key to reading the Epodes." Watson $(2003,17)$ continues by paraphrasing Gagliardi that "it is unthinkable, he [Gagliardi] insisted, that Horace, in taking over as he did the poetic ideals of Callimachus, should have bypassed the poetae novi," and in particular Catullus whom he "adapted" (quoting Watson) and adopted extensively in the Epodi. Watson $(2003,17)$ also considers Heyworth's (2001,117-119) views stating that he

has rightly insisted that there is much that is demonstrably Archilochean and iambic in the Catullan corpus: [...] it is thus possible to argue that Horace drew inspiration from the twin conduits of Archilochus and 'Archilochean' Catullus, even if the latter debt went unacknowledged.

Watson $(2003,19)$ quotes two of the poems by Maecenas (fragments 2 and 3, Courtney, 2003) addressed to Horace with "explicit echoes of Catullus.” Thus, we find in Horace's Sermones and Epodi, which were written in 30s B.C., and also in Maecenas' poetry echoes of Catullus. It is very plausible that Horace knew of Maecenas' sympathy for the poetae novi and Catullus and that he saw the potential of Maecenas' preference for his own purpose. Hence, he interlaced both S.1 and the Epodi with Neoteric and Catullian elements to please Maecenas in order to enhance the chance of success of his self-presentation: in other words, the Catullian allusions are subtleties within the iambic genre for the connoisseur Maecenas.

I examined Horace's political engagement in my thesis entitled The Augustan Poets: Their Master's Voices? (Weeda, 2010, 238-243). Although I would not now agree with some of the approach in the latter study, I regard my conclusions about Horace's role of political commentator as still valid. I (2010, 239) argued that Horace "maintained his output of engaged political poetry at a constant level during his life." About a quarter (44 poems) of his total output has a topical political content; half of those are concerned with the civil war and his expectations of better times under Augustus' leadership. Fifteen poems are supportive, twelve are critical of Octavian or of the regime in general. However, there is a significant difference. The supportive poems are almost absent before Actium and nearly all are written after 27 B.C. The critical poems are evenly distributed between 42 and 11 B.C., indicating the poet's independence: Horace was not Augustus' voice in a putative propaganda programme. Up to the present, the view that the Sermones contain political messages has not 
been generally held. For example, Lowrie $(2007,80)$ argues that Horace's political involvement starts with the Epodi and reads the Sermones as showing “[Horace's] private stance in satire, and the consistent depiction of his participation in Maecenas' circle as non-political." However, I agree with DuQuesnay $(1984,57)$ who argues that Horace expressed in a number of Sermones his views on contemporary social and political developments, but that at the time he did not yet write "as a detached observer, but as the friend of Maecenas.” He $(1984,57)$ regards the poems as an expression of the poet's genuine belief that Octavian was the best hope of "achieving peace, prosperity and freedom."

A colleague observed in a private communication that Horace himself "constantly refers to Lucilius as his predecessor." He mentions S.1.1, S.1.4, S.1.10 and Ep.2.2 as evidence, which I will examine in section 2.2. He states that Horace "plays with the word satis and its connection with satura (S.1.1.120: iam satis est)." In my analysis of S.1.1 in section 2.2.1, I consider S.1.1.119 (satur) and S.1.1.120. I will argue that these lines do not refer to satire, as attributing satiric characteristics to the Sermones is presumably post-Horatian, perhaps even post-Quintilian. These lines are primarily an intertextual allusion to the last lines of Virgil's Ecl.10 thus delivering the message of the latter, that is a critical commentary on contemporary politics. Discussing S.1.4 in section 2.2.2, I note that unlike Lucilius (and Juvenal) Horace never addresses in S.1 wrong-doers directly. In the same sermo, he doesn't wish to imitate Lucilius, but he does not say either that he wants to be a satiric poet. The colleague refers also specifically to S.1.4.78-80 of which he claims that Horace "notes that his [Horace's] criticism has ruffled feathers (S.1.4.78-80)" meaning that in those lines he is accused of malicious backbiting, in other words writing sharp satire. I will present below in section 2.2.2 a very different reading of these two lines, namely that this passage relates to the poet's view on behaviour among friends. ${ }^{60}$ They should certainly censure each other if necessary, but this should be done in a civilized manner, and the passage is just the opposite of a case for satire. In my view, S.1.10 is least of all an example of Horace referring to Lucilius as his predecessor. I will argue in section 2.2.5 that he in S.1.10.48-49 states that he does not presume to take the crown of satirical poetry from Lucilius. Those two lines are not "a mock-deferential bow from the inheritor to the inventor of satire" (Gowers, 2012, 328), but they tell us that he does not want to be the inheritor and that he does not intend to write satiric poetry. Finally, the colleague cites Ep.2.2.60 as evidence that Horace himself sees some of his work as satire. This line is part of a passage (Ep.2.2.55-65) about old age: tendunt extorquere poemata ([the years] tend to take away from my poems). He asks what to do knowing that not everyone has the same taste (denique non omnes eadem mirantur amantque).

60 With thanks to an anonymous reviewer of this book. For the significance of Horace using three times the word niger (or word-forms) in the passage S.1.4.78-103 for my interpretation, see my discussion in section 2.2.2 and note 167 . 
Then, he mentions in lines 59-60 three of the genres he engaged in and which have different followers: you like the carmen (carmine tu gaudes), the one takes pleasure in iambics (Horace's Epodi) (hic delectatur iambis), and the other delights in sermones like those of Bion with their wicked wit (ille [delectatur] Bioneis sermonibus et sale nigro). Horace makes two intertextual allusions to S.1 in Ep.2.2.60: the first one to his title of S.1, Sermones, and the second to the word niger in S.1.4.85. One should note that Horace used again the word Sermones and not Saturae. The second allusion (niger) is to $S .1 .4 .85$, a line that closely follows the very same lines which the scholar quoted earlier as referring to satire, which I discussed above. I will also argue in section 2.2.2 below that Horace gives in S.1.4.78-85 a catalogue of malice that in his view cannot be tolerated among friends. Line 85 closes this passage with the warning that one should stay clear of the man who is malicious to his friends: hic niger est, hunc tu, Romane, caveto (he is the wicked, of him, true Roman, take heed). Taking the two allusions in Ep.2.2.60 together, I suggest that Horace indicates that he prefers that one reads $S .1$ as conversation pieces (Sermones), and that some men may like Bionian satires, but that he does not share their liking and would not wish to produce poetry "with wicked wit (sale nigro)." I will present my interpretation of Horace's attitude towards Bionian satires in section 2.2.3 when I discuss his libertino patre natum (a freedman's son) in S.1.6.45-52. As an aside, we will see in the discussion of S.1.4.85 that I also interpret the words "hunc tu, Romane, caveto" as Horace's functional reference to his belief in the old Roman values, mos maiorum, which are for him an inspiration for his moral guidance.

Muecke (2007, 117), among others, poses the question "why, in a specific political and cultural context, Horace turned satire away from political invective towards quietism and witty, but unthreatening, moral criticism." Gowers $(2012,11)$ also remarks that Horace turned satire "from a bursting, angry genre into a slim and contented one." Horace wrote indeed a less biting and more friendly form of poetry because he had a specific objective in mind. ${ }^{61}$ This was not a literary objective, but a functional one. He wanted to write his political commentary for Maecenas and his new circle of friends in recognisable literary forms. It is likely that Horace felt that his contribution to the debate about political issues should not be delivered in the manner of Lucilius, as he may have been of opinion that the traditional invective style used in satires at the time was counter-productive in getting his political views across. Freudenburg (2001, 20-21) explains the less invective nature of Horace's Sermones by pointing out that the latter above all seems to be motivated by his own social career. He states that Horace's self-interest is apparent from the dedication of the first book of Sermones to Maecenas: QVI fit, Maecenas, ut nemo (how can it be, Maecenas, that nobody). He (2001, 21) refers to Oliensis $(1998,17-18)$ by stating "recently, Ellen Oliensis has remarked on the obvious irony that inheres in naming Maecenas so prominently in the first half-line

61 Anderson (1982, 13-28); Freudenburg (2001, 4-9; 15-23); Gowers (2012, 6-12). 
of a poem [S.1.1] where social climbers are freely abused: the act of naming Maecenas lets us see the social climber in Horace himself." Oliensis $(1998,18)$ says indeed that "it was presumably by means of poems such as Satires 1.1 that Horace courted and won the favor of Maecenas. The satirist climbs the social ladder by poking fun at social climbers." However, on the same page she states that "it is impossible either to convict or to acquit Horace of the charges - unscrupulous ambition, opportunism, materialism, parasitism - to which his autobiography made him vulnerable.” By this last statement, she leaves the question whether Horace should be seen as a social climber open. Although Horace made indeed a dazzling career from a loser at Philippi to a member of Maecenas' circle of friends, I will present my arguments that he should not be seen as a social climber in my discussion of S.1.6.111-128, a typical day in the poet's life. Freudenburg $(2001,21)$ also states:

His book's dedication to Maecenas, while blunt and minimal, the least elaborate dedication in all Latin literature (a single word), carries powerful implications for the speaker's self, and the way his lessons will be received: it puts him squarely inside a world of Roman social relations where promising young poets look to men of means to provide them access to books, learned audiences, and facilities, as well as abundant political and financial rewards.

As mentioned above, Horace's Sermones are less abusive than for example those of Lucilius. Nisbet $(2007,9)$ states that "his ambiguous origin and new-found caution [after his involvement with Brutus' party] kept him from attacking important people in either genre [Satires and Epodes].” I concluded in Weeda (2010, 240-241; 340; 396) that the poet was critical of the leadership and the policies of Octavian in a number of the Sermones and Epodi, and that he did not trade away his independence for his admission as a member of Maecenas' circle or for the gift of the Sabine estate, nor that the nature of his relationship with Maecenas was such that he felt obliged to hold back in his critical commentary (see the closure of section 1.4). Gowers $(2012,1)$ states in the opening sentence of her commentary that "Satires I, published around 36/5 BC, is Horace's debut, a point of departure, in which he explains how he arrived where he is and where he might be going in the future." Gowers' statement can be read as an interpretation of $S .1$ that comes pretty close to mine.

Schlegel (2005, 3-18) suggests a different incitement for Horace's style of poetry. She $(2005,6)$ also raises the question of which "authority inheres in the satirist that justifies his hearers' attention.” She argues that

The listener looks to the source of the speech, the speaker of blame, to justify his attention to such speech; and the result is that the satirist himself is as much the object of attention as his speech.

I [Schlegel] argue that Horace creates a persona for himself, as the satiric speaker in book 1 of the Satires, which can be understood as a response to the tensions inherent in the operation of hostile speech. Readers of Horace's Satires have often seen his poems as anomalous to the genre of satire. Horace's satire is mild, not harsh, and presents none of the risky sting that we expect from satiric speech; Juvenal, far better than Horace, conveys the tone we associate with satire. 
Yet the poems of Satires I delve more deeply into the crucial issues inherent in the genre than do those of any other Roman satirist.

What type of persona does Horace create? Although he identifies audiences as targets for blame poetry, he does not censure those in a direct confrontation. Schlegel (2005, 7) recognizes that Horace intends to avoid conflict when she observes "what the poems of book 1 do, rather than enacting conflict - that is, speaking invective against an audience - is to present the issue of powerful speech and domination that inhere in satire." In her view, Horace's "satiric" persona reveals the unequal power between speaker and hearer, that is "the power of speech to menace, control and overpower the hearer." Horace mitigates this burden of inequality by not addressing his targets by himself, but by different speakers. I suggest that the appearance of those different speakers is not the result of a psychological need of Horace's "satiric" persona to invalidate the threat of satiric speech, but of the poet's symbolizing the different contributors to a conversation. ${ }^{62}$ Schegel $(2005,10)$ also suggests that the attributes Horace grants to his "satiric" persona "from his tiny verbal output to his low social status, act as a counterweight to the expectation of a satiric speaker who exercises clout, auctoritas of an overweening kind, over his listener." I read, however, in the poems many clear and critical expressions of ethical and political points of view.

Although the form and content of $S .1$ was determined in the first place by Horace's objective to present himself as a reliable member of Maecenas circle, he nevertheless already gives in S.1 some of his first commentary on contemporary Roman social and political life to Maecenas. In addition, he recognizes that he should give his commentary without antagonizing his listeners by the traditional style of the satiric genre. Horace did not choose his style on literary grounds, or to achieve psychological effects, or to further his social career, but to further his professional career. We will see in the course of analysing the poems that he adopts the style of the gentleman commentator with some characteristics of a jester. In this way, he keeps the communication with his associates open, and their attention remains focused on the subject matter and not on the way of presentation. In addition he chose for book 1 of the Sermones the form of a sermo because he believed that this form was the most appropriate one to meet his functional objective: to make a contribution to a civilized discussion among friends about socio-political issues. The Sermones are a form of poetic conversation, a sermo, as Anderson $(1982,13-49)$ convincingly argues. ${ }^{63}$ Sermo also has the connotation of a philosophical conversation. But, in my opinion, this should not be taken literally in the case of S.1. Horace writes indeed about matters

62 Schlegel (2005, 8-9) points out that Horace intends his satiric persona to take full account of his "principle of balance," that is "the idea of limitation that must be embraced if one is to be content with merely enough.” However, I see this as one of the poet's philosophical convictions, and not as one of his ideas for the style of his satiric genre.

63 For the Sermones as a form of poetic conversation, see also Gowers (2005, 48-50). 
of moral virtue - like avarice, unbridled ambition, lack of restraint - or writes about frank criticism (parrhesia), which are firmly rooted in Hellenistic philosophy. Further, he adhered to the Epicurean circle of Philodemus and he identifies what he considers the failings of Stoic teachings. Apart from engaging Maecenas and his associates in a philosophical discourse, he also raises or alludes to those issues in S.1 in order to demonstrate that his socio-political views have a firm basis in contemporary moral philosophy acceptable to Maecenas. This raises the question of the audience or audiences of $S .1$, and it is useful to discuss this issue at this stage with the help of the classification of Gold (1992, 161-175). ${ }^{64}$ She distinguishes in $S .1$ four audiences. The first one is the primary audience, that is the dedicatee of S.1.1, and also according to Gold $(1992,163)$ "probably of the book as a whole once it was put together.” The addressee is Maecenas, who is present one way or another in virtually each poem of S.1, and is a "prominent theme" who also happens to lend "dignity and authority to the poem by his name and presence.” However, I differ from Gold’s $(1992,164)$ view that Maecenas is presented in S.1.1 "as a friend who is interested in philosophical disquisitions on contentment and greed and is the suitable recipient of a diatribe on these subjects.” The same can also be argued for a number of the following individual sermones like S.1.2-1.4 and S.1.6, although those poems have different subject matters than S.1.1. I will argue in this book that Maecenas is indeed present as a (potential) amicus: however, not one for philosophical conversations, but one who must get acquainted with Horace and be convinced of the latter's worth as a companion of the other members of Maecenas' circle. The second audience, which Gold (1992, 164165) calls the internal audience, is "the vague second-person addressee, recipient of Horace's constant questions and exhortations. [...] It is also the group that displays the very set of qualities that Horace has set out to admonish and correct [... and] which we, the actual audience, and Horace's authorial audience can scorn and mock.” The latter statement by Gold, namely that the actual and authorial audiences of the sermo can scorn and mock the set of qualities that Horace has identified for his commentary and criticism, supports my view that he wrote the Sermones as "papers" for discussion with Maecenas and his associates. The first question is: who are the members of these two audiences? The second is: what are the qualities that are criticized? First, the authorial audience is Gold's third layer audience consisting according to her (1992, 163) of "the first-century B.C. Roman upper-class writers and politicians to whose experience and values Horace appeals and who could be counted on to understand the full effect of Horace's mixed signals and ironic tone." I see the description of the group of men as applicable to Maecenas' circle of associated writers like Fundanius, Melissus, Plotius Tucca, Propertius, L. Varius Rufus, and Virgil (see also note 45), the philosopher Philodemus and politicians like Cocceius Nerva, Fonteius Capito, and Lucius Licinius Varro Murena, Maecenas' brother-in-law. Gold's actual audience is

64 I am indebted to an anonymous reviewer to bring her (1992, 161-185) work on S.1 to my notice. 
the person who is reading or hearing a text at any given moment: in our case the contemporary readers of or listeners to a sermo of Horace. Second, concerning the question about the qualities to be criticized, Gold $(1992,165)$ gives us examples of those from S.1.1: "lines 4-8, 15-19, 43, 51, 64-67, 80-83, 95-100," representing the vices of envy, discontent, greed, lack of restraint and ambition. Thus, I understand Gold to say that she reads S.1.1 as Horace's account of the vices of the internal audience presented to Maecenas and members of his circle to be scorned and mocked by them. I broaden her interpretation - if I understand her correctly - and I will argue in section 2.2.2 (at the closure of S.1.3) that in S.1.1-1.3 the members of the elite, the new rich and the extreme Stoics constitute the internal audience. The sermo is Horace's account of the vices of this internal audience presented to Maecenas and members of his circle in order for them to learn about Horace's social status and political views. Horace's purpose is not to admonish those groups as satiric poet. ${ }^{65}$ When Horace mentions individuals or groups in a sermo, he does not intend to address them, but to consider with Maecenas and his associates the views, behaviour or actions of these individuals or groups. Interpreting the outcome of Anderson's (1982) work in a functional frame, I identify four attributes of the Sermones which support this view. First, an indication that Horace intended his Sermones as a form of poetic discourse emerges from his choice of style having characteristics of the conversational mode. For example, Horace used simple language as this encourages the conversational style. In S.1.4.41-42 he wrote: si qui scribat uti nos/ sermoni propiora (if one writes more like conversational prose, as I do). That is not to say that Horace intended to write in a style similar to prose, as we will see below, when I discuss S.1.4.38-62 in more detail (see section 2.2.2). Horace shows there that his sermones - the word he used three times in the passage - can match the best of poetic standards. ${ }^{66}$ He proves in the passage, especially in lines 39-44 and 56-62, his talent (ingenium) and skill of composition (ars), and especially his mastery in word-order. Oberhelman and Armstrong $(1995,244)$ discussing the comparison with Ennius made by Horace himself in lines S.1.4.53-62 say about the latter

that Horace has managed to prove [...] two points: that metathesis [changing the word-order] will destroy good poetry (and so Horace's satires [in my view sermones] are good poetry), and that Ennius' verse, while poetry, is not good poetry because the effects of metathesis are minimal.

65 Contrary to Rudd $(2007,35)$, who argues that Horace speaks directly to his audiences. See also Gold (1992, 166-169), who $(1992,168)$ hints at my interpretation referring to S.1.1.19 where nolint "objectifies the people addressed here and makes them into a part of the story rather than direct addressees." See also the discussion of line 19 in section 2.2.1.

66 For Horace and the poetic qualities of his Sermones, see Anderson (1982); Freudenburg (1993, 145 150); Oberhelman \& Armstrong (1995). 
Thus, Horace's poetry matches that of the best of poets from the past. In addition, he uses simple conversational words, as Anderson (1982, 25) notes about S.1.4.39-44:

Now, looked at from a different side, these lines exhibit the special poetic possibilities of satire. Although the writer deals with a subtle argument, he explains his thoughts in simple language. [...] Horace makes sure that important words are assigned to the key structural points of the hexameter. [...] Thus, we might say that Horace here proves how different sermo is from epic, but he also subtly shows that his own sermo, because it does so much more than imitate conversation, deserves the title of poetry.

This passage in the fourth sermo suggests that Horace had carefully considered his approach. By writing down these lines in a very early stage of his poetic career, he defines his position with Maecenas and his confidants as a poet. A second indication is Horace's use of the first-person persona (see section 1.3.1). In the Sermones, he often refers to autobiographical events, but it is likely that many of the described events never actually took place. In the case of $S .1$ these "autobiographical" contexts may also have a specific purpose. Horace, a newcomer in the circle of Maecenas' confidants, may pretend that his socio-political commentary is based on "real" experience. In other words, stories about journeys to Brundisium, meetings with important people, or his youth in Venusia, are his credentials with which he supported his reliability and experience as an observer of political and social trends. Third, as we saw above, Horace dedicates the whole first book of Sermones to Maecenas by the address to him in S.1.1.1, and he addresses Maecenas again in S.1.6.1. ${ }^{67}$ This also indicates that the poems were intended as conversation pieces for Maecenas. ${ }^{68}$ The Sermones were not written for general distribution, but specifically for Maecenas, and through the latter for Octavian, and perhaps delivered to the addressee and a small group of trusted men in the latter's immediate circle. ${ }^{69}$ According to Gowers (2012, 11): "H.[orace] writes for exclusive Roman coteries and shuns the crowd.” Gowers' $(2012,19)$ conjecture that Horace's “"private' dialogues are broadcast well beyond his circle of chosen readers" may be right to some extent, but this was not the poet's intention writing these poems. This is also borne out by Horace himself who in S.1.4.22-23 says cum mea nemo/ scripta legat vulgo recitare timentis (while nobody reads my writings, and I fear to recite them in public). Fourth, comparing the programme proposed by Freudenburg (1993) with mine, I register that Freudenburg recognizes that the Sermones are not only poems

67 The "address" in S.1.10.1fr. to Lucilius is most likely spurious as it is part of the first eight interpolated lines; see also Gowers (2012, 309). Further, Maecenas is mentioned in S.1.3.64; S.1.5.27, 31, 48; S.1.6.47; S.1.9.43; S.1.10.81. None of the poems of $S .1$ is dedicated to Octavian, although he is mentioned by name in S.1.3.4.

68 See also Freudenburg (1993, 22; 2001, 20); Zetzel (1980, 62-64). For the question whether the Sermones were intended by Horace as teaching conversations, see Freudenburg (1993, 12-19); Gowers (2012, 12-15).

69 Conform DuQuesnay $(1984,57)$. 
with moral lessons, but also have much to say about aesthetics. ${ }^{70}$ In his own words (1993, 185):

Yet even the diatribes, which seem, at times, half-witted, the most unsophisticated of all the poems of Horace, conceal a second side, a metaphorical dialogue exposing the aesthetic values of the poet and his commitment to writing elegant, highly allusive poems in the Callimachean tradition.

Freudenburg gives many examples of this second side. I suggest that in addition to the two sides that he proposes, the moralizing and the aesthetical, Horace's Sermones have a third side, that is the political, on which I focus.

\subsection{Sermones, Book 1: Conversation Pieces}

I mentioned that Horace wrote a less biting and more friendly form of poetry with a socio-political purport than for instance Lucilius as he had a specific objective in mind, that is that he wanted to raise political questions for debate with Maecenas and the circle of his newly found friends. It is likely that Horace felt that his opinion should not be delivered in the aggressive manner of Lucilius. However, Horace may have had primarily a different, special, reason to write a somewhat subdued first book of poetry. He was probably admitted to the group connected with Maecenas in 39/38 B.C., which was only four years after his ignominious role at the battle of Philippi. ${ }^{71}$ Only three to four years later, he released book 1 of the Sermones in 36/35 B.C. When Horace started writing his first Sermones in the late forties or early thirties B.C., he, at the relatively young age of twenty-seven, was launched into Maecenas' group presumably without much experience in writing poetry with a socio-political content. I intend therefore to explore whether the first book can be read as a collection of poems in which he not only offers his credentials as a loyal member of the group, but also practices the art of writing poetry with a critical political content, that is acceptable for Maecenas and his entourage. Therefore, he may have considered the genre of the Sermones suitable for using the instrument of what I call the functional reference. I have discussed the notion of the functional reference above in section 1.2. I will identify many examples of Horace using those references when he makes a political point.

The first three Sermones, also called Horace's diatribes, are according to Rudd $(2007,1)$ "sermons of a rather special kind. They do not call for allegiance to any divine

70 For "Morals and Aesthetics in the Satires," see Freudenburg (1993, 185-198).

71 For Horace's involvement in the battle of Philippi at Brutus' side, see Carm.2.7.9, Carm.3.4.26, and Ep.2.2.49. See also section 1.3.2. 
power or any sacred writings, nor do they urge us to repent and seek salvation. Their only appeal is to common sense. What is it, they ask, that makes man unhappy?"72 In the diatribes the place of individuals in society and their behaviour in a moral sense are at issue, not that of the institutions. In these three poems, the poet directs his criticism at different people and he is concerned with ethical lessons of all kinds. In what follows, however, I do not use the traditional classification of the poems, such as S.1.1-1.3 constitute the group of the "diatribe satires." I propose an arrangement of the poems that follows Horace's efforts to secure his newly found position as a candidate member of Maecenas' circle. Horace presents his developing views on socio-political themes in the individual poems, thus enabling him to introduce himself to Maecenas through a range of subjects which the poet chooses himself for discussion. The individual sermones are very much related to each other; I concur very much with Oberhelman and Armstrong (1995, 237-239), who state that S.1 "should be read and considered as a whole" $(1995,237)$. In my opinion, this relationship is a result not only of Horace's main objective, that is his self-presentation which shows in S.1.5-1.9 an increasing confidence that he will be accepted by Maecenas. It is also a result of his developing views on his place in Maecenas' circle and his role as a future political commentator; it should be noted, that he often refers back, for example in S.1.4 back to S.1.1-1.3 and in S.1.10 to S.1.4. I arranged the poems in the following groups of two: Sermones 1.1 and 1.2: The cynical ways of the aristocracy and the nouveau riche (section 2.2.1). Sermones 1.3 and 1.4: From censuring the elite and the nouveau riche to a serious conversation with friends (section 2.2.2). Sermones 1.5 and 1.6: Horace's credentials for Maecenas continued: a journey to Brundisium; youth and education in Venusia and Rome (section 2.2.3). Sermones 1.7 and 1.8: Threats from the East: Parthia and Egypt (section 2.2.4). Sermones 1.9 and 1.10: Maecenas' circle: no place for nouveau riche. Horace's literary programme for several genres, the literary schools revisited (section 2.2.5).

\subsubsection{Sermones 1.1 and 1.2: The Cynical Ways of the Aristocracy and the Nouveau Riche}

Horace, after dedicating in the first Sermo his book to Maecenas with only three opening words QVI fit, Maecenas (how can it be, Maecenas), directs our attention to the discontent of many who envy other people. They complain as they believe that

72 For S.1, see Anderson (1982, 13-41); Ferriss-Hill (2015); Freudenburg (1993); Gowers (2005, 4857; 2012, 1-28); Lefèvre (1993, 85-111); Oliensis (1998, 17-40); Schlegel (2005); Shackleton Bailey (1982, 10-31). For Sermones 1.1-1.3, see Freudenburg (2001, 15-27); Turpin (2009). For individual sermones, see Ferriss-Hill (2015); Freudenburg (1993); Rudd (2007) and the commentaries of Brown (2007) and Gowers (2012). 
other men do always better than they and that they stand a poor chance in life. Lines 1-3 read:

QVI fit, Maecenas, ut nemo, quam sibi sortem seu ratio dederit seu fors obiecerit, illa contentus vivat, laudet diversa sequentis? (how can it be, Maecenas, that nobody lives content with the lot that he either chose himself, or chance threw his way, but has praise for those who pursue other courses?)

In lines 4-12, he gives us examples: the soldier envies the trader and the reverse, the jurist the farmer, and the countryman the city dweller. Horace claims in S.1.1.13-14 that he can give many more examples: cetera de genere hoc, adeo sunt multa, loquacem/ delassare valent Fabium (other examples of this type [of men], so many are they, could even wear out loquacious Fabius), who according to Gowers $(2012,66)$ "may be Fabius Maximus (according to the scholiasts a Pompeian and a Stoic - allowing H.[orace] to kill two birds with one stone), the Theophrastus of his day." Similarly to Horace in the opening of S.1, Fabius also recounted in his writings the conduct of different types of men (genere hoc). Fabius, however wrote from a Stoic point of view, and Horace makes through the functional reference to Fabius immediately clear at the start of his book that he does not wish to be associated with the latter's Stoic views. He will reiterate this point in S.1.3.96-98 where he criticizes the Stoic view that all sins are equal and in S.1.3.124-128 where he ridicules the Stoic paradox (see section 2.2.2). We saw in section 1.1 that Horace's objective in writing $S .1$ was to convince Maecenas that he was the right man to be associated with the latter's circle and that he held the right political views, which were not those held by the Stoics. Horace wants to assure his readers that his association with the Republicans belongs to the past after Philippi. The Stoics were generally found within the camp of the Republicans and Pompeians. In addition, Horace describes Fabius as long-winded, as he presumably tired out his audience with his Stoic views. Horace, however, intends to write in a much more sophisticated and subtle manner, as he will appeal to his readers' education and sophistication. This is apparent from lines 14-15, in which he used the word deducam in line 15. Freudenburg $(1993,111)$ called attention to the use of deducam; in my opinion it indicates both the poet's intentions concerning style and those concerning his political posture. Freudenburg observes that Horace will present against Fabius' garrulity and unbridled free speech - both attributes for which the Stoics were known - "his own refined practices (1.1.14-15): Ne te morer, audi/ quo rem deducam ('lest I detain you, hear how I reduce the matter at hand')." He suggests that the word deducam may allude to a carmen deductum. ${ }^{73}$ We will see in the discussion

73 For carmen deductum, see Deremetz (1995, 287-314); Freudenburg (2001, 36-38); Keith (2002, 246). For the meaning of carmen deductum in ancient historiography, see Rosati (1999, 246-247; 2002, 276); 
of the final lines of this sermo that Freudenburg (2001,37), comparing iam satis est (now, it is enough) in S.1.1.120 with Virgil's haec sat erit (it will be enough) in Ecl.10.70, and saturae capellae in Ecl.10.77, points out that in the final lines of Virgil's book of Eclogae the images of substance and fullness of the capellae saturae go together with "something delicate" and thin of the "just 'sufficient' muse." The metaphor, when applied to the closure of Ecl.10, is "about thickness just as much as it is about thinness." Freudenburg concluded from this concomitance of the two poetic voices that Virgil used the carmen deductum to refer to the rich intertextual memories of Virgil's contemporary readers. Deremetz $(1995,299)$ suggests something similar: "pourrait donc bien symboliser la tradition poétique antérieure" (could therefore indeed symbolize earlier poetic tradition). I argue in Weeda and van der Poel (2016), that the rich intertextual memories which Virgil prompts consist of allusions to the contemporary political situation. It is feasible that Horace, by using the carmen deductum in the early lines of his work (S.1.1.15), also refers to the rich intertextual memories of his readers. Further, an anonymous reviewer of this book brought to my notice that there is still another facet of the closure of Ecl.10 to consider. He states that "the Vergilian ending is part of a larger pattern of explicit linguistic allusions to closure." When I discuss S.1.1.119-120 below I will examine in more detail the likely meaning of Horace's closure of S.1.1 in the light of Virgil's closure of Ecl.10. ${ }^{74}$

Returning to the carmen deductum, Horace achieves two objectives. Firstly, the poet makes a statement about his style as a politically engaged poet, "that is, the poet [Horace] resembles the spinner who carefully twists and spins a large tuft of carded wool into a fine, narrow thread. The satirist, unwilling to harangue his audience at length, 'reduces' his theme to the simple stage metaphor of lines 15-22" (Freudenburg, 1993, 111). Secondly, he confronts through Fabius a whole group of contemporary poets, Stoics, republicans and generally men of a very different political leaning than Horace. $^{75}$

Wheeler (2002, 170n23). For VERG.Ecl.10.70-77, see Weeda \& van der Poel (2016), where this passage about the carmen deductum was discussed before.

74 We suggest in Weeda \& van der Poel (2016, 204-205), that Virgil alludes in Ecl.10.70-77 to the following: the image of the sated goats being taken home to rest when evening falls suggests that Virgil encourages the reader to take time to reflect on the grave matters which he broaches in this ecloga and indeed in the whole of the book by means of indirect or allusive references. Similarly, when I discuss below the closing lines of S.1.1, I will propose that Horace does not need to spell out his political views in the last two lines of S.1.1, but that he shows those by a functional reference to the final bucolic lines of Ecl.10 and through this to the whole of the tenth Ecloga, and indeed to the whole of the book of Eclogae. For the larger pattern of linguistic allusions, see Fowler (2000, 245-249); Hardie (1997, 142 -151); Schrijvers (1973); Smith (1968).

75 We will meet windbag Fabius again in the last line of S.1.2. Not counting his poet friends in S.1.5, Fabius is only the first of six contemporary poets mentioned by Horace in the first book of Sermones; the other five are Crispinus (in S.1.1.120; 1.3.139; 1.4.14), Fannius (in S.1.4.21; 1.10.80), Caprius and Sulcius (in S.1.4.65-66, 70). I do not count in these six his poet friends, Virgil, Plotius and Varius. For 
Next, Horace shows in S.1.1.15-22 not only that his style will not be as bombastic and unrestrained as that of Fabius and others, but also that contemporary philosophies such as Stoicism, are not necessarily the only guides to responsible behaviour. The passage begins with si quis deus 'en ego' dicat/ 'iam faciam, quod vultis' (if some god should say "hello there, I will do what you want at once"). Horace forsakes the philosophers invoking in S.1.1.15 and in S.1.1.20 Jupiter. However, he does not expect much of such a course as he demonstrates in the simple stage metaphor of lines 16-22: even if a god were to offer the moaners of lines 1-12 to change places, there would be no takers. Lines 17-19, put in the simple language of a stage director, read: "hinc vos,/ vos hinc mutatis discedite partibus: eia!/ quid statis?" nolint. atqui licet esse beatis (you here, you there, move and change parts: get a move on! why standing there?" they will not do it. And yet, they could be happy). In lines 20-22, he describes the failure of the god's involvement. The lines read:

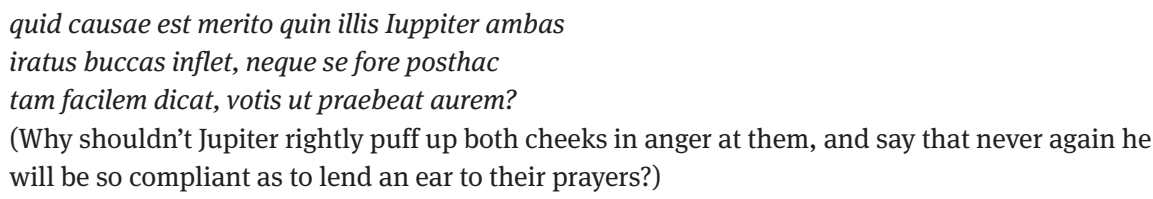

Horace says in S.1.1.15-22 that there is nothing that brings those discontented to reason, not even a god who listens to their prayers and Jupiter's anger. I interpret Horace's metaphorical use of the god's anger that he is convinced that the people who feel wronged refuse to act according to either philosophical tenets or to the old veracities of the traditional Roman values, as they follow their own course any way. He is not surprised that those people do not follow the Stoic doctrines, which indeed he also rejects. But, those people are to blame for rejecting the old Roman values, as a return to those values might contribute to greater political and social stability and coherence. Thus, summarising S.1.1.1-22, the opening of Horace's first book of Sermones, I conclude that the passage contains a very important statement about the first book. When I discussed lines 13-14, I argued that those were written to convince Maecenas that he held the right political views, which were not those held by the extreme Stoics, of whom many were Octavian's opponents (see also my discussion of S.1.3.124-142). By referring to the gods in lines 15-22, he adds to this the positive statement that the old Roman values are the foundation of his outlook upon life.

A brief interlude (lines 23-27) follows, in which the poet "apologizes” for his lack of serious talk when dealing with weighty issues. The interlude functions perhaps also as a form of literary "stage management." Contrary to Gowers (2012, 68-70), who interprets this short passage in a literary frame, namely that "Horace continues to

the contemporary poets mentioned in the books of Sermones, see Freudenburg (1993, 109-119). For Fabius in S.1.1, see Freudenburg (1993, 110-111), and see also note 100. For Fannius, see note 141. 
experiment with generic influences," I interpret these lines as Horace wanting to recover his breath after he closed in line 22 his reflections on essential choices for his future. In the course of discussing the ten sermones of the book, we will see that Horace knows as to how the philosophical connects with the practical. Therefore, he may have considered presenting his views on the everyday ethical issues in the first poem of the book of vital importance.

I argued in section 2.1 that Horace identified in S.1.1-1.6 distinct social groups not only to determine the poetic genre and the style he would use as political observer, but also to demonstrate to Maecenas that he did not adhere to the views or supported the actions of a number of those groups. He depicts in detail in the greater part that follows, S.1.1.28-107, the characteristics of distinct groups enabling Maecenas to judge the poet's convictions. I will analyze the poet's views and relate those to the characteristics of the groups by determining who speaks about a certain issue. He returns in line 28 to the subject with which he opened the satire: the discontent of many people, envying others. S.1.1.28-32 tells us why they are so restless:

\begin{abstract}
ille gravem duro terram qui vertit aratro, perfidus hic caupo, miles nautaeque per omne audaces mare qui currunt, hac mente laborem sese ferre, senes ut in otia tuta recedant, aiunt, cum sibi sint congesta cibaria

(he, who with the strong plough turns over the heavy soil, and also the dishonest innkeeper, the soldier and the sailors, who rashly sail every sea, they say that they bear their labour with this in mind, that when old they may retire into secure comfort, when they have their provisions heaped up)
\end{abstract}

The discontented farmer, innkeeper, soldier or sailor have one thing in common, that is their desire to get rich and enjoy a comfortable retirement when old. Horace constructs in the following lines his own fable of the ant hoarding her wintersupplies by hauling all she can to the heap that she is piling up (trahit quodcumque potest atque addit acervo/ quem struit) (lines 34-35). However, in the end the greedy men differ considerably from the prudent ants, as they do not stop amassing riches. S.1.1.40 reads: nil obstet tibi dum ne sit te ditior alter (nothing can stop you, so long as you can prevent someone else from becoming richer than you).

From line 41, Horace censures greed for the next sixty-six lines, which according to Gowers $(2012,72)$ "comes to form the main body of the poem until the recapitulation at 107." The poet asks in lines 41-43 the miser quid iuvat immensum te argenti pondus et auri/ furtim defossa timidum deponere terra? (What is a huge weight of silver and gold of use to you, if like a thief you get rid of it buried in the ground in fear?). The miser answers that his wealth will disappear, if he were to divide his hoard into small parts (quod si comminuas). Then, the poet asks in line 44 what is the beauty of such a pile, if the heap (acervus) remains intact. He explains in lines 45-60 that man ought not to cross natural borderlines, and that man does not need more food and drink than his 
body can cope with. Even if the greedy man's wealth could give him a gigantic crop of grain, the man's stomach will not take more bread than the poet's (non tuus hoc capiet venter plus ac meus). And, even if the miser were to be the young slave (venalis) who had to carry the heavy bread-bag (reticulum panis) for the whole gang, he would not get an extra ration.

Next, the poet accentuates his arguments for restraint in satisfying natural desires by advocating to stay within nature's bounds. In lines 49-53 he suggests that when a man lives in harmony with nature it does not matter whether he ploughs a hundred or a thousand acres (iugera centum an/mille aret), as long as he can take all he needs from the smaller piece of land: dum ex parvo nobis tantundem haurire relinquas,/ cur tua plus laudes cumeris granaria nostris? (as long as you allow us to take just as much from our little heap, why should you praise your granaries more than our baskets?). In lines 54-58 he gives a forceful impression of man's greed and the consequences of stepping outside nature's bounds in the allegory of the man who needs a cup of water, but takes the cup from a wild river rather than from a tiny brook. Their greed makes them blind for the burden of amassing more riches than one needs. ${ }^{76}$

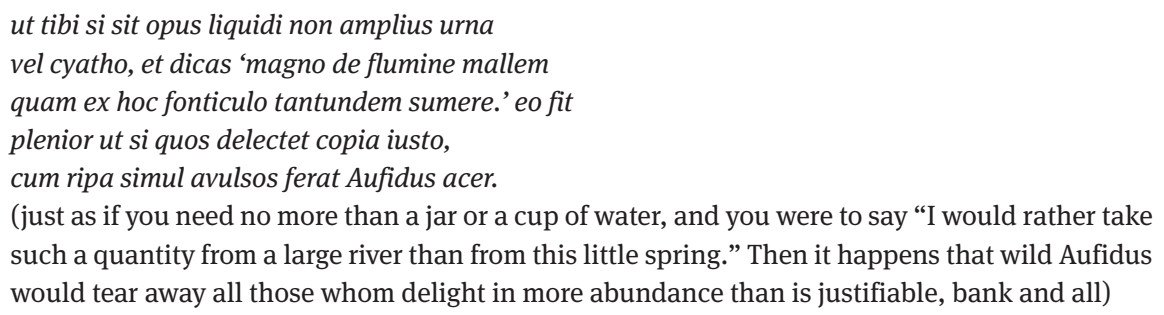

Gowers $(2012,74)$ remarks that "specifying the river's [Aufidus'] name makes this a cautionary tale such as H.[orace] might have heard at his father's knee.” Horace's reference to the Aufidus (now Ofanto) has a special meaning indeed, although this is not just "the cautionary tale," which undoubtedly also is a message of the poem. The more important point of the allusion is that Horace takes us back to his youth in Venusia by mentioning the river. Gowers hints at this when she sees the child "at his father's knee." Apart from S.1.1.58, the poet mentions the river only three times. The most notable mention is in Carm.3.30.10, in the exegi monumentum (I completed a monument) carmen, the famous last one of the third book, when he remembers his childhood and his rural background. In the second mention, in Carm.4.9.2, he also refers to his origins, and he expects his poetry to remain just as the wide-echoing river will always be there. The last reference, in Carm.4.14.25 is a political allusion

76 For the other frame in which this passage can be read, see Freudenburg (1993, 187-190). Freudenburg $(1993,189)$ interprets this as: "Horace buries other clues in the illustration to suggest that he intends the image metaphorically, as a jibe against the wild, unrestrained verbiage of his poetic rivals." 
to Tiberius' military action in Gallia, devastating like the Aufidus. ${ }^{77}$ Horace uses the functional reference to the river Aufidus to locate the allegory of the greedy man having a drink in the river in his native town. It is feasible that Horace refers here to what he experienced in his youth, when the greed and arrogant conduct of the new class of rulers, the military, called the shots in Venusia (also mentioned in S.1.6.72-75), and consequent destruction of the traditional social structure of his home town. I will further consider the significance of Horace's reference to the Aufidus at the end of the discussion of S.1.1.

In lines 61-63 Horace gives us one of his beliefs that for many people enough is not enough:

at bona pars hominum decepta cupidine falso

'nil satis est' inquit, 'quia tanti quantum habeas sis.'

quid facias illi? iubeas miserum esse

(and a good many men, deceived by false desire, says "one cannot have enough, for you are worth as much as you have." What to do to one who talks thus? Do not grudge him being miserable).

Who does the poet think is miserable? A subtle move in the targets of Horace's censure becomes visible. The poem started in lines 1-40 with the poet criticizing average citizens, like traders, sailors, soldiers, farmers, lawyers, innkeepers, but moves away from those in line 41 towards misers, who, obsessed by their fear of losing their money, can belong either to old families with large fortunes or to the increasing group of new rich. Apart from the reference to Fabius in line 14, Horace refers in lines 64-65 to an unnamed Athenian misanthrope, to Ummidius (line 95) and to Naevius and Nomentanus (lines 101 and 102); the passage S.1.1.41-107 does not give much certainty who the four men could be. However, some names certainly indicate that in the words of Rudd $(2007,138)$ "some of these characters may be classified by their attitude to money," referring specifically to Ummidius and characterizing him as the Roman counterpart of an unnamed Athenian miser (Rudd, 2007, 22). ${ }^{78}$

Yet, I infer that Horace refers in lines 61-62 to the new rich in Rome on grounds of the specific choice of words. Using the words bona pars hominum (a good many men), Horace indicates that rather many people think that one cannot have enough, for one is worth as much as one owns (nil satis est, quia tanti quantum habeas sis). He wrote bona pars because he observed that this thinking was particular manifest within the large emerging group of the new rich, rather than in the circumscribed group of the old rich. In addition, Horace's rejection of the ways of the new rich is also

77 For Carm.3.30.10, see also Nisbet \& Rudd (2007, 374). For Carm.4.9.2, see also Putnam (1986, 160161). For Carm. 4.14.25, see also DuQuesnay (2009, 272), and Putnam (1986, 245).

78 For the unnamed Athenian misanthrope, see Gowers (2012, 75), who mentions that Timon of Athens was suggested by Ps.-Acro. For Ummidius, see Gowers (2012, 79); Rudd (2007, 22; 138). In Rudd $(2007,138)$ we read about Ummidius that he was "known to have been dead." 
a theme in S.1.2, 1,3, 1.5, and 1.9, and indeed later in for example Carm.2.18 and 3.1. ${ }^{79}$ Further, I will argue below that Naevius and Nomentanus - and also the anonymous fellow ("the pest") of S.1.9 (see the discussion of S.1.9) - refer to the spendthrift types belonging to the group of the new rich. In the next lines 63-91, Horace suggests that avarice is the cause of much misery for a rich man, who cannot enjoy the pleasure of having money, but worries about losing it. In S.1.1.69-75, Horace depicts with humour the miser gloating over his riches, who does not use his money providing for himself and his family buying only the daily necessities.

fabula narratur; congestis undique saccis

mutato nomine de te

indormis inhians et tamquam parcere sacris

cogeris aut pictis tamquam gaudere tabellis.

nescis quo valeat nummus, quem praebeat usum?

panis ematur, holus, vini sextarius, adde

quis humana sibi doleat natura negatis.

(if you change the name, it is your story; you go to sleep gaping at a pile of bags [of money] on all sides, and you must protect them as if they were sacred or delight in them as if they were pictures. Don't you know what cash is good for, or for what it should be used? For buying bread, vegetables, a pitcher of wine, together with other things that cause suffering for human nature if denied)

In the following lines, S.1.1.76-78, Horace tells us what befalls such a man: he is half dead with fear (metu exanimem) that he will be robbed.

an vigilare metu exanimem, noctesque diesque

formidare malos fures, incendia, servos

ne te compilent fugientes, hoc iuvat?

(Or to be awake half dead with fear, and to dread night and day nasty thieves, fires or slaves, lest they rob you and disappear, does this please you?)

The poet points out that wealth cannot buy health, happiness or love; the miser is left to his own devices in times of sickness, even by his wife and children. In lines 86-87 he tells us why, when with much irony he puts the rhetorical question: miraris, cum tu argento post omnia ponas,/ si nemo praestet quem non merearis amorem? (are you surprised, if nobody shows you the love which you do not deserve, when you place money above all?).

In S.1.1.92-94 he summarizes the poem this far (lines 4-91):

79 For a discussion of the nouveau riche constituting Gold's internal audience, see section 2.1. For a further discussion of the position of nouveau riche in Roman society at the time, see the summary of S.1.1. For Horace's rejection of the nouveau riche in Carm.2.18 and 3.1, see my discussion of S.1.2. 
denique sit finis quaerendi, cumque habeas plus

pauperiem metuas minus et finire laborem

incipias, parto quod avebas

(briefly, let there be a limit to the search [for wealth], and now that you have more let your fear of poverty abate, and begin to finish your work, when you acquired what you wished)

His message in the next passage of this early poem (lines 95-107) is that one should not run to the other extreme, that is behaving in the same way as spendthrifts Naevius and Nomentanus (lines 101 and 102). According to Rudd (2007, 141-143; 147; 221-223) Naevius and Nomentanus cannot be identified positively. Nomentanus is perhaps a typefigure, but in $S .1$ and $S .2$ much evidence exists that Nomentanus anyhow was known as a spendthrift. ${ }^{80} \mathrm{~A}$ Nomentanus also features prominently as a gastronomic connoisseur in the last sermo, S.2.8, the story of the dinner party with some dramatic effects, such as the awning which comes crashing down halfway during the meal and the departure of the guests before the meal had ended. The dinner was hosted by the unknown Nasidienus Rufus with Maecenas as guest of honour. The ostentatious display of wealth, however, is typical for a meeting of the new rich, which brings Horace in S.2.8.18 to a short, but sharp commentary: divitias miseras! (the misery of wealth). In S.1.1.95-107, Horace describes a certain Ummidius, an unknown wealthy miser, who for fear of poverty continued amassing wealth, which is often a typical characteristic of the new rich. Horace contrasts the wealthy miser with the spendthrift Nomentanus telling Ummidius that he should keep a middle course. However, in my view, there is another point that Horace makes. Nomentanus is someone who functions well in the milieu of the new rich, as his role as connoisseur in S.2.8 shows. It is noteworthy that Nomentanus features in both the very first and the very last sermo in contexts of great wealth, and therefore it is feasible that he is besides being the typefigure of a spendthrift he is also that of a nouveau riche, or a new rich himself, who continued to show his wealth in Rome during the period of writing S.1 and S.2. Horace makes a point of presenting those types as representatives of the new class of the rich, who could afford the most extreme opulence and indulge in excesses.

Line 106 gives us one of Horace's most fundamental beliefs: est modus in rebus (there is measure in things). In the final passage from line 108, he returns to his starting point and repeats that avarice makes a man unhappy and envious of his neighbour. Some scholars argue that lines 117-120, near the finale of the poem, are an

80 For Nomentanus as a spendthrift, see Gowers (2012, 80): "Elsewhere in H.[orace], Nomentanus is usually a spendthrift.” Muecke $(1993,156)$ : “Nomentanus is the standing example of the spendthrift.” He features in S.1.8.11: Nomentanoque nepoti (spendthrift Nomentanus), in S.2.1.22: Nomentanumque nepotem, in S.2.3.174-175: extimui [...]/ tu Nomentanum, tu ne sequerere Cicutam (I feared greatly, that you [the one] might follow [spendthrift] Nomentanus, and you [the other] the [money-lender] Cicuta), and in S.2.3.224-225: luxuriam et Nomentanum arripe mecum;/ vincet enim stultos ratio insanire nepotes (arraign with me extravagance and Nomentanus; for Reason will demonstrate conclusively that spendthrifts rage like fools). 
allusion to the end of Virgil's Ecl.10. ${ }^{81}$ I will discuss this allusion in more detail below. S.1.1.117-120 reads:

inde fit ut raro qui se vixisse beatum dicat, et exacto contentus tempore vita cedat uti conviva satur, reperire queamus. iam satis est.

(thus, it happens that seldom we can find someone who says that he lived happily, and who, once his time is fulfilled, will die in contentment like a guest who has eaten enough. Now, it is enough)

Horace shows with iam satis est that he knows when to stop. The poem ends with a dig at Crispinus, an endless Stoic babbler suffering from an affection of the eye, who very likely belonged to the Pompeian party. Horace says in lines 120-121 that one should not think that he pillaged the book-boxes of bleary-eyed Crispinus: he will not add a word more (ne me Crispini scrinia lippi/ compilasse putes, verbum non amplius addam). Knowing when to stop is something that the greedy and ambitious men, for whom enough is not enough, never do. Horace admonishes them of the limits in their search for power and wealth suggesting that they should follow the example of the well satisfied dinner guest, who does not stuff himself. ${ }^{82}$ We will meet the Stoic Crispinus again in S.1.3.139 and S.1.4.14 - and indeed many other Stoics at different places in the whole of $S .1{ }^{83}$ Horace brings them on the stage in a similar role as Crispinus in the present line, that is the role as a Stoic adherent of Sextus Pompey linked with the wrongdoings of certain groups. DuQuesnay $(1984,54)$ points out already that "the scraps of information [concerning the names in $S .1$ and the possibilities of links with for example the proscribed] tend to support the earlier speculation that Stoicism had a special connection with the Pompeian-Republican cause." I intend to carry DuQuesnay's "earlier speculation" a step farther by demonstrating that Horace indeed used the Stoic connection with the Pompeian cause to the full in S.1. I mentioned already in section 1.1 that Horace's objective was to convince Maecenas of his trustworthiness by showing him that he was an Epicurean and that therefore his social background and political views were acceptable for joining the circle of Maecenas' associates.

Summarizing S.1.1, I suggest that Horace's mention of firstly avarice and ambition throughout the poem, secondly the allusion of the final lines of S.1.1 to those of

81 Freudenburg (2001, 27; 35-40); Putnam (1995, 314-315); although van Rooy (1973) shows that Horace alludes in most sermones of book 1 to Virgil's Eclogae, he does not discuss this particular intertextuality.

82 For the image of the satisfied guest see, Freudenburg (1993, 112, 192-193; 2001, 36-37); Gowers (2012, 82).

83 For Horace's targets (including Crispinus) in S.1, see DuQuesnay (1984, 53-56). For Crispinus, see Freudenburg (1993, 112-113); Gowers (2012, 84-85); Rudd (2007, 133). 
Ecl.10, and, thirdly, the reference to the river Aufidus in line 58 are significant for understanding the functional meaning of the poem.

Firstly, Horace's focus on avaritia, ambitio and luxuria is often seen as commonplace simple philosophy, but as DuQuesnay (1984, 32) already argues, "the themes themselves are the commonplace of Hellenistic philosophy, what is striking and novel is that these poems treat moral issues seriously and at length." Gowers (2012, 59) recalls DuQuesnay's work when she states: "though the wider historical context is largely written out of the diatribe satires, the disruptive activities they catalogue, like debt, greed, adultery and vindictiveness, happen to recall the charges of anti-social behaviour hurled about between the different sides in the civil wars (Duquesnay 1984)." DuQuesnay (1984, 34-35) makes the point that Horace attacking the vices of avaritia, ambitio and luxuria echoes the contemporary hostile propaganda against the Triumvirs. He $(1984,34)$ states that "it may also be assumed that the Pompeians alleged that the Triumvirs (principally, of course, Octavian who was in Rome) were motivated by avaritia, ambitio and luxuria since these were the conventional and established characteristics of those who waged civil war.” Horace depicts himself and Maecenas as very concerned about the erosion of moral standards, and its impact on the political situation. According to DuQuesnay it is likely, that this was a popular feeling at the time, and in attacking greed and ambition he recalls for instance Sallust, who in Bellum Catilinae 10-11 writes that Rome has achieved his power through hard work and justice, but that this will collapse if the present erosion of the traditional standards goes on. ${ }^{84}$ SAL.Cat.10.2-5 says:

Qui labores, pericula, dubias, atque asperas res facile toleraverant, eis otium, divitiae, optanda alias, oneri miseriaeque fuere. Igitur primo pecuniae, deinde imperi cupido crevit; ea quasi materies omnium malorum fuere. Namque avaritia fidem, probitatem ceterasque artis bonas subvortit; [...]. Ambitio multos mortalis falsos fieri subegit,

(those who had found it easy to endure suffering, danger, uncertainty, and adversity, considered leisure and prosperity, desirable under other circumstances, a burden and a misery. Hence, first the greed for money, followed by that for power, grew; these had been, as it were, the source of all evils. For greed destroyed trustworthiness, honesty, and all other worthy qualities; [...] Ambition incited many men to become false)

Next, in chapter 11, Sallust instances and explains in greater detail the vice of avaritia. Although these kinds of complaints may seem worn out feelings, Sallust (and indeed Horace) most likely express a widespread view in Rome that the greed of the powerful has led to the contemporary problems of civil war and political and social strife. In Horace's opinion, however, it is the greed of the powerful in general from different layers of society (aristocrats, the new rich, freedmen and the military) that caused the

84 For additional relevant sources by Sallust in Bellum Iugurthinum 3, and later testimonies by Plutarch and Cassius Dio, see DuQuesnay (1984, 34-35). For the text of Sallust, see Reynolds (1991). 
contemporary problems, and not the actions of only the Triumvirs or Octavian. Sallust wrote these lines most likely at some time between 44 and 40 B.C., only a few years before Horace began writing the first book of the Sermones.

Secondly, Horace accentuates his words about the social and political risk of unrestrained greed and ambition of the elite by alluding through satur in line 119 and iam satis est in line 120 to Virgil's Ecl.10.70-77, that reads: ${ }^{85}$

Haec sat erit, diuae, uestrum cecinisse poetam,

dum sedet et gracili fiscellam texit hibisco,

Pierides: uos haec facietis maxima Gallo,

Gallo, cuius amor tantum mihi crescit in horas

quantum uere nouo uiridis se subicit alnus.

surgamus: solet esse grauis cantantibus umbra,

iuniperi grauis umbra; nocent et frugibus umbrae.

ite domum saturae, uenit Hesperus, ite capellae.

(divine Muses, it will be enough for your poet to have sung, as he sits and weaves a basket of slender marsh-mallow: you shall make these verses for Gallus beautiful - Gallus, for whom my love grows hour by hour, as much as the green alder shoots up in a new spring. Let us get up. The shade is usually unpleasant for singers, the shade of the juniper tree is harsh, and shades also hurt the crops. Get home, my sated goats, get home; the Evening Star comes)

When I discussed above S.1.1.14-15, I mentioned that iam satis est (now, it is enough) in S.1.1.120 shows that Horace knows when to stop. But we also saw that there is more to that as Freudenburg $(2001,37)$ argues, namely the poet's appeal to the rich intertextual memories of Virgil's contemporary readers. The question is who refers in those lines to whom; does Horace refer to Virgil, or does Virgil perhaps refer to Horace? The latter wrote S.1.1 between 38 and 36/35 B.C., while Virgil most likely wrote Ecl.10 in 41/40 B.C. (see Weeda, 2015, 79). Thus, if Horace wrote (or adapted) S.1.1 after 38 B.C. the reference can be an allusion to a text by Virgil. If Horace wrote the first sermo earlier than 41/40 B.C., which is unlikely, Virgil may not have yet produced Ecl.10. It seems to me that the most convincing argument that the allusion was inspired by Virgil comes from the bucolic nature of Horace's lines. This is in line with Freudenburg's $(2001,38)$ argument, that the allusion to Ecl.10 makes us realize "that Horace can be just as subtle and allusive in his Sermones as he is elsewhere.” But allusive to what? To pre-existing texts or to a common source, or to a discussion between the two poets? Freudenburg $(2001,38)$ questions the scholarly image of Horace, that as a poet of the Sermones "he leaves a lot to be desired," and the view that only "with the help of Virgil and friends, he transforms himself into that learned, densely allusive scholar-artist we know so well from the Odes." Freudenburg states that this view needs to be corrected, and that the significance of Horace's intertextual allusion to Virgil shows that he knows how

85 For Virgil's Ecl.10, see also note 74, Weeda (2015, 76-83), and Weeda \& van der Poel (2016, 204-205). 
to use the dialogue with pre-existing texts. $\mathrm{He}(2001,39)$ asserts that with the allusion Horace challenges our views of genre and that our "generic expectations [...] are given a thorough shake, and notions of genre are then necessarily reconfigured." Yet, there is an additional aspect to Horace's allusion to Virgil, that may be as important or perhaps more so than challenging our views of genre. My point is indeed that when the poet works within the functional frame, the instrument of a functional reference enables him to express the message of a text through an allusion to another text. Thus, Horace does not need to spell out his political views in the last two lines of S.1.1, but he shows those by a functional reference to the final bucolic lines of Ecl.10 and by means of this to the whole of the tenth ecloga, and indeed to the whole of the book of Eclogae. I argued before that for Virgil's Ecl.10.70-77 "two functional interpretations may be appropriate: Vergil invites us to read his last Eclogue with both sympathy for Gallus' tortured love that cannot be healed and with an awareness of the contemporary political situation. Firstly, the fellow-feeling is evident in the poem as a whole, as he implies, by mentioning Gallus' name seven times, that he wants us to give thought to the fate of Gallus, and is also visible in lines 73-74, where he says that his love for Gallus grows hour by hour. Secondly, the image of the sated goats being taken home to rest when evening falls may suggest that Vergil encourages the reader to take time to reflect on the grave external matters which he broaches in this eclogue and indeed in the whole of the book by means of indirect or allusive references. In the Eclogues, Vergil offers a plate stuffed full (satura) of those references to the personal suffering and destruction caused by the civil war and the land expropriations, and to the general disruption of the economic and social structures, elegantly served in pastoral poetry." ${ }^{\text {I }}$ I mentioned above at the discussion of the carmen deductum that a reviewer pointed out that the Vergilian ending of Ecl.10 may have broader significance (see also note 74$)$. Fowler $(2000,246)$ describes "the phenomenon of supertextual closure" and gives as an example Horace's Carm.3.30 which "clearly closes the whole collection of the first three books of Odes." If one applies the phenomenon to Virgil's closure in Ecl.10.70-77, Virgil can be seen as closing not just the tenth ecloga, but the whole book. Following on from this, Horace may have recognised Virgil's supertextual closure and refers to the whole book of Eclogae by means of his reference to Ecl.10 in S.1.1.119-120. Therefore, Horace achieves two objectives by these final lines: firstly, a statement about his approach to writing poetry, namely that he does not carry on endlessly, but knows when to stop, and secondly the delivery of the message which the book of Eclogae expresses, that is a critical commentary on contemporary state of affairs. As it were, Horace associates himself with the political views of Virgil, who introduced him to Maecenas, and demonstrates thus that he is one of them.

Thirdly, I stated above that Horace's reference to the river Aufidus also has a special meaning. Why did he choose the Aufidus, the river which flows near

86 See Weeda \& Van der Poel $(2016,205)$. 
Venusia? This is similar to Virgil's reference in Ecl.10.47 to the river Rhenus, which flows near Virgil's hometown Mantua. I conjecture that Horace made indeed in S.1.1.54-58 a similar functional reference as Virgil did. I argued earlier (Weeda, 2015, 79-80; see also Weeda \& van der Poel, 2016, 196-200) that Virgil's functional objective was to locate $E c l .10$ in his native area. Therefore, he located the fictive absconding of Lycoris in his home region by referring to the river Rhenus. Ecl.10 is a poem about the destruction of the economic and social structures in Northern Italy caused by the civil war and the ongoing struggle for power. I suggest above that Horace uses the same instrument of a functional reference to the river Aufidus in order to locate the allegory of the greedy man having a drink in the river in his native town. Horace refers here to the greed and ambition of the new class of men in power, the centurions who in his young days called the shots in Venusia (also mentioned in S.1.6.72-75), and who lined their pockets through the expropriation of the assets of the indigenous population, whom they often also reduced to slavery, like perhaps Horace's father, making the poet technically a freedman's son (see also section 1.3.2 and note 25).

Thus, at the close of S.1.1 two lines come together. Firstly, Horace's criticism of greed and ambition and his concern about the impact of the loss of moral standards of both common people and the new rich on the political stability in Rome and Italy, implying that his worst expectations have come true. The poet's fascination with and rejection of the many nouveau riche, who say "one cannot have enough, for you are worth as much as you have" (line 62), suggest that these men were very visible in Rome gaining much influence and being accepted by many of the social and political elite. The appellation "nouveau riche" or "new rich," who were either the wealthy free-born (ingenui) upstarts or the new rich freedmen (libertini) and their sons, needs some elucidation. I use the term for those upstarts and military men, who often got rich by means of dubious commercial interests and of profiting by the land redistributions. Horace showed his concern about the threat of their materialistic attitude, their hunting for status, and lack of restraint to the stability in Italy combined with the effects of the ongoing power struggle after the end of the civil war. These effects were very visible in the land expropriations. Many of the new rich used their wealth unashamedly either for exorbitant private expenditure or for attempts to buy political office. In the time of the Late Republic, the number of new rich swelled considerably by the increase of the number of freedmen (libertini). They or their sons often won their wealth in an acceptable manner or otherwise either by their success in commerce and agriculture or by exploiting their position with a patron who held a high status. The wealth of these freedmen or their descendants could match that of the rich ingenui. ${ }^{87}$ Obviously, the majority of the freedmen and their sons lived

87 For the general position of freedmen, see Treggiari (1969). For rich freedmen, see Treggiari (1969, 239-240). 
in moderate circumstances and were occupied in activities such as teaching, small trades, or managing their former master's estates.

Secondly, Horace alludes twice to Ecl.10; the one at the end of the poem, and the allusion to the Aufidus. I stated above that I interpret these allusions as Horace associating himself with Virgil's condemnation in each ecloga of the expropriations and the expulsions in Italy and of the destruction and social upheaval caused by the civil war and its aftermath. ${ }^{88}$ One may wonder why Horace joins Virgil through those hidden allusions, and why he does not speak more openly. I suggest that at the time of writing S.1.1 Horace did not want to bring to light too openly a critical view of Octavian's involvement in the struggle for power. The outcome of the civil war was still undecided: Sextus was defeated at Naulochus in 36 B.C. and Actium still had to come in 31 B.C. Horace wrote S.1.1 before both events, between 38 and 36/35 B.C. Horace may have felt that as a new man in Maecenas' circle, blemished by his former allegiance to Brutus, he did better not to speak too openly in his first poem about delicate major political subjects in Maecenas' presence.

Sermo.1.2 begins with the funeral of the singer Tigellius, of whom Horace in line 4 says quippe benignus erat (seeing that he was generous). ${ }^{89}$ The funeral procession consists of flute-girls, quacks, priests of Cybele, mime actresses, jesters, and all that kind of folk (hoc genus omne). Gowers $(2012,92)$ says of Tigellius, that he "throughout epitomizes the tasteless, ostentatious prima donna (against the reticent H.[orace]); he is also a model of inconsistency ([S.1]3.9) and adaptability ([S.1]3.130 optimus... modulator)." I do not concur with the second half of Gowers' statement that the Tigellius of S.1.2 was "a model of adaptability." In my view, the qualification of inconsistency applies indeed to the Sardinian Tigellius of S.1.3.1-19, who is the same man as the one described in lines $1-4$ of the present sermo. I will discuss this more fully when I analyse S.1.3 in the next section 2.2.2. The qualification of adaptability, however, applies to a second man, namely Hermogenes. I will explain this in more detail when I discuss S.1.3.128-133. The Tigellius (of S.1.2), who is praised by his entourage for his generosity, is indeed a playboy in Rome of the first-century B.C., and symbolizes in S.1.2 the faults of the Roman patronage system which buys second-rate loyalty. Porphyrio (at S.1.2.1-3) wrote about him that "the talented musician Marcus Tigellius Hermogenes belonged to the household of Gaius Caesar, the dictator, and

88 For political commentary in Virgil's Eclogae, see note 4, Weeda (2015, 54-84), and Weeda \& van der Poel (2016). For the dating of the book of Eclogae, see Weeda (2015, 60). For the dating of Ecl.10, see Weeda $(2015,79)$.

89 For S.1.2, see Freudenburg (1993, 40-46; 193-198); Freudenburg discusses S.1.2 from a literary perspective. He $(1993,193)$ states: “Trained in rhetorical theory, Horace knows the metaphorical terms whereby sex becomes a symbol for style, and he freely avails himself of these to set off his aesthetic values against those of his rivals." In section 2.1, I explained that my research is based on a functional perspective. For S.1.2, see also Gowers (2012, 86-118); Kemp (2016); Shackleton Bailey (1982, 10-14). 
later to that of Cleopatra, because he sang pleasantly and jested wittily. Augustus liked him as well." Nevertheless, the identity of Tigellius poses a problem. ${ }^{90} \mathrm{~A}$ Tigellius also features in a number of other sermones, in S.1.3.4, S.1.4.72 (Hermogenes Tigellius), S.1.10.80 (Hermogenes Tigellius) and S.1.10.90. One of the reasons for the uncertainty of Tigellius' identity is his funeral as reported in S.1.2.1-4, while in S.1.10 he appears to be alive. On grounds of S.1.10.17-19, scholars argued that Horace writes in S.1 about two different men..$^{91}$ I will explain in my discussion of S.1.10.17-19 (in section 2.2.5) that I concur with DuQuesnay's $(1984,56)$ view that it is likely that two men are involved. However, DuQuesnay is not clear whether he suggests that Horace writes about a dead Tigellius and a living Hermogenes at different places in S.1. I will argue at S.1.10.17-19 that Horace writes about the dead Tigellius only in S.1.2 and S.1.3.4, and about Hermogenes at other places (S.1.3.129, S.1.4.72, S.1.9.25, S.1.10.18, 80 and 90).

Horace accentuates the "generosity" of Tigellius by contrasting him in lines 4-5 with a man who does not give a penny to his needy friend fearing to be seen as spendthrift (contra hic, ne prodigus esse/ dicatur metuens, inopi dare nolit amico). Next, Horace describes the opposite, that is the extravagant man in lines 7-11:
hunc si perconteris, avi cur atque parentis
praeclaram ingrata stringat malus ingluvie rem,
omnia conductis coemens obsonia nummis,
sordidus atque animi quod parvi nolit haberi
respondet. laudatur ab his, culpatur ab illis.
(if you were to ask someone else why he wickedly through his insatiable gullet strips the ancestral estate of his grandfather and father, buying up brought-in provisions of every kind on borrowed money, he answers that he does so because he does not want to be seen as a cheapskate and mean. He is praised by some, reproved by others)

Rich Fufidius, a miserly moneylender, is his next target. He charged an extravagant interest on loans (five per cent a month), and he took the interest in advance. In lines 14-15 Horace writes: quinas hic capiti mercedes exsecat, atque/ quanto perditior quisque est tanto acrius urget (he deducts five times the [normal rate of] interest off the principal, and the more desperate someone is, the harder he presses). Even more reprehensible was that he ensnared vulnerable youths having strict fathers into borrowing money. One would think that Fufidius would spend a fair share of his income on his own pleasure and comfort, but in reality the miser is a not a friend to himself (line 20: sibi non sit amicus). Horace gives in lines 23-28 some more examples

90 Porphyrio's text (Meyer, 1874, 190) is: Marcus Tigellius Hermogenes musicae artis scientia praeditus Gaio Caesari dictatori fuit familiaris, postea Cleopatrae, quia dulciter cantabat et iocabatur urbane. Augusto quoque ita placuit.

91 For Tigellius and Hermogenes, see DuQuesnay (1984, 56); Freudenburg (1993, 114-117; 168-170); Rudd (2007, 139); Ullman (1915). See also my discussions of S.1.3.1-13, S.1.3.128-133, S.1.4.65-78, S.1.9.2125 and S.1.10.17-19. 
of people not knowing their borderline and searching for the extreme. For example, the street scene of unknown Maltinus and his opposite (line 25), who according to Rudd $(2007,143)$ represent respectively "an effeminate fop," and the "extreme [...] of virile exhibitionism.” According to Rudd $(2007,143)$ and Gowers $(2012,95)$ the name Maltinus denotes apparently effeminacy and could be derived from maltha (tabletwax). Warmington (1967, 240-241) gives the ancient commentary on Lucilius.744 by Nonius Marcellus (37.6) (after second, before fifth century A.D.): “Nonius,37,6: 'Maltas'

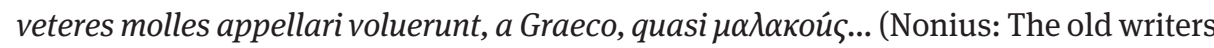
by using of men the term 'maltae' meant 'soft,' from the Greek, as it were $\mu \alpha \lambda \alpha \kappa o i$ (or $\mu \alpha \lambda \theta \alpha \kappa o i ~ ?) . ..) . ” ~ L u c i l i u s .744$ reads: "insanum vocant quem maltam ac feminam dici vident (they call him a madman whom they see to be known as 'mollycoddle' and 'feminine.')."92 Unmanly Maltinus walks with trailing robes (Maltinus tunicis demissis ambulat), and his unnamed macho opposite (est qui) in line 25 wears them raised as far as his obscene groin (inguen ad obscenum subductis usque). Horace closes the passage about objectionable manners in public with one line in which he contrasts Rufillus, smelling of lozenges (pastillos) used to give an agreeable smell to one's breath, with Gargonius stinking of a goatish smell (hircum). The latter two names are most likely type-names, although they may have been two well-known characters walking the streets of Rome. ${ }^{93}$ Rudd $(2007,137-138)$ remarks that the two men are depicted as contemporaries, and that the poet repeating the line with exactly the same words in S.1.4.92 "implies that it had given offence" in reality. In this passage Horace makes the point that those people run into opposite extremes, and do not follow a middle course: nil medium est (line 28).

The lack of a middle course is also very apparent from the ways of men who do not know how to choose wisely their preferred ways of sexual gratification, being the subject of the remainder of the poem. They go for either the extreme of adultery with a married woman (matrona), who wears "a gown fringed at the bottom with a flounce" or for that of a prostitute (meretrix) in a stinking brothel (line 30: olenti in fornice). Horace writes in lines 28-30:

nil medium est. sunt qui nolint tetigisse nisi illas

92 A reviewer points out that $\mu \alpha \lambda \alpha \kappa \circ \varsigma$ is Attic and $\mu \alpha \lambda \theta \alpha \kappa o \varsigma$ Aeolic. The renderings into English of the texts of Nonius and Lucilius are by Warmington. For Nonius Marcellus, see Lindsay (1903). Gowers and Rudd refer to ancient rumours that Maltinus alludes to Maecenas. Rudd $(2007,148)$ states: "the latter certainly dressed in an effeminate style, and the satire in question was written before Horace met him. But if this was a genuine allusion it is hard to explain how Horace could have published the poem unchanged after enjoying Maecenas' patronage for over three years.” (italics are mine) Gowers (2012, 95) concludes that if Maltinus were to allude to Maecenas "his opposite, the priapic flasher, is a caricature of H.[orace] the satirist.” In my opinion, all rather unlikely.

93 For Rufillus and Gargonius as type-names, see Gowers $(2012,96)$. For the two men, see also my discussion of S.1.4.92 below. 
quarum subsuta talos tegat instita veste; contra alius nullam nisi olenti in fornice stantem.

(there is no middle course. There are those, who would not want to have touched women unless she hides her ankles with a gown fringed at the bottom with a flounce; another on the contrary none unless posing in a stinking brothel)

Horace "quotes" in lines 31-36 Cato the Censor, who according to Gowers $(2012,99)$ "justifies brothels as a more straightforward outlet for natural lust than adultery, in rousing man-to-man language - unlikely endorsement by the tight-lipped censor." Although Cato is known to have advocated moderation in visiting prostitutes, his approval may be the result of his strong opposition to extra-marital affairs. An unknown Cupiennius holds the opposite view; S.1.2.35-36 reads: 'nolim laudarier' inquit/ 'sic me' mirator cunni Cupiennius albi ("I would not want to be commended for that," says Cupiennius, "an admirer of licentious matrons”). ${ }^{94}$ The middle course, however, is also problematical. $\operatorname{Kemp}(2016,134)$ states that "the fact that adultery is considered out-and-out wrong, and the seedy prostitute is, as Rudd (1966 [= 2007], 11) notes, 'half condoned', already suggests an unevenness in Horace's use of the mean as a model for his argument which some have thought problematic.” Kemp $(2016,137)$ remarks that adultery is "practically forbidden" as it "is regarded as a non-virtuous, morally wrong choice" contravening the generally accepted "social and moral code of the time." Horace recommends the freedwoman (libertina) as the favourable choice of middle course in lines 47-48: tutior at quanto merx est in classe secunda,/libertinarum dico (but how much safer are the wares in the second class - of freedwomen, I mean), but according to Kemp $(2016,137)$ the poet finds the "mean difficult to attain there too."

In the passage of lines 47-110, Horace introduces the subject of sexual scandals in Roman high society. We will see that the women and men who are depicted are members of the elite, and also that the context of their standard of life is that of the upper class: buying horses in line 86, domestic staff in line 98. The first one is Sallust, probably the historian, whom the poet makes a lover of freedwomen, although he is also known for his affair with Fausta, the daughter of Sulla, of whom we will hear more later. Next, in lines 55-63 the unknown Marsaeus - the lover of Origo (amator Originis ille), "Miss Newcome," and according to Gowers $(2012,103)$ "an upwardly mobile mime actress" - appears. The reference to a mima (mime actress) is especially of interest, as

94 The literal translation of mirator cunni albi is "the connoisseur of a white-robed pussy." For the name Cupiennius, see Rudd (2007, 143; 145). Although Porphyrio (see Meyer, 1874,192) identifies Cupiennius as Gaius Cupiennius Libo Cumanus, whom he describes as Augusti familiaritate clarus corporis sui diligentissimus fuit sectator matronarum concubitus (famous for his friendship with Augustus; as he was very cautious with his body he chased married women to sleep with). I follow Rudd $(2007,145)$ who doesn’t find this identification credible: acc. to Gowers (2012, 99-100), Cupiennius is most likely a type-name "blending cupere ‘to desire' with Ennius, anticipating the direct Ennian quotation in 37-8." 
at the time mime actresses were favourite girl friends of upper class men: I will discuss one special mime actress, Cytheris, below. ${ }^{95}$ Marsaeus says in lines 55-57 that an affair with a mima is preferable to that with somebody's wife. S.1.2.55-63 reads:

\begin{abstract}
ut quondam Marsaeus, amator Originis ille, qui patrium mimae donat fundumque laremque, 'nil fuerit mi' inquit 'cum uxoribus umquam alienis.' verum est cum mimis, est cum meretricibus, unde fama malum gravius quam res trahit. an tibi abunde personam satis est, non illud quidquid ubique officit evitare? bonam deperdere famam, rem patris oblimare, malum est ubicumque. quid inter est in matrona, ancilla, peccesne togata?

(just as once Marsaeus, that lover of Origo, who gave his father's estate and home to an actress, said: "I will never get involved with the wives of other men." But [you do] it with actresses, with prostitutes, and as a result your reputation suffers more than your property. Or is it good enough for you to avoid the part [of adulterer], and not that what in any case stands in your way? To lose your reputation, to squander your father's estate is bad anywhere. What matters it whether you consort with a lady or with a whore?)
\end{abstract}

Horace explains in this passage that mime actresses are not a good middle course either: they tend to be expensive, destroy one's reputation, and squander one's money. Horace refers in lines 55-63 to Marsaeus' irresponsible and extravagant conduct squandering his father's inheritance on his mistress or mistresses: line 56 qui patrium mimae donat fundumque laremque (who gave his father's estate and home to an actress). He also says in line 58 briefly and to the point: verum est cum mimis (but you do it with actresses). Brown $(2007,107)$ remarks on the possibility of an allusion to Marc Antony's well-known affair from 49-45 B.C. with Cytheris, a famous mime actress, also known as Volumnia as she was bought out of slavery by Volumnius Eutrapelus. However, Brown does not further discuss the possible allusion. ${ }^{96}$ A colleague made the point that "given that their [Antony's and Cytheris'] relationship had ended in

95 For the affairs mentioned in S.1.2.47-110, see Gowers (2012, 102-113). Two names in this passage cannot be identified, i.e. Cerinthus in line 81 and Catia in line 95. However, acc. to Gowers (2012, 108; 110) both are described as members of the elite.

96 Acc. to Gowers $(2012,103)$ Marsaeus is unknown, but "perhaps there is a link with the satyriasis of satyrs, a taste for libertas matched by a taste for libertinae," or the name of Origo "may also be a specific allusion here to Cato's Origines, Sallust's pet text [...]: Marsaeus' favourite book will have been Orig.2, where the origins of the Marsi are discussed.” The Marsi were a people in Latium, known as wizards and snake-charmers. If Gowers' conjecture is developed further, one speculation could be that if Cytheris (her name refers to Cythera, famous for the worship of Venus) is seen as having strong seductive powers, Marsaeus may well allude to Antony’s powers of enchanting women. Gowers $(2012,103)$ in her commentary on the next line 56 hints at Cytheris: "mime actresses (cf. 2) were often libertinae: e.g. Antony's friend Cytheris (Cic. Fam. 9.26.2).” 
45 [B.C.], its topicality ten years later seems dubious.” I consider Brown's suggestion very credible as Antony's affair (est cum mimis) had been very much in the spotlight and was at the time of writing of the satire still fresh in the collective memory. Several ancient testimonies relating to the affair survive, by Plinius the Elder (Nat.8.55) and by Cicero (Att.10.10.5, Phil.2.24.58; 2.25.61; 2.25.62; 2.26-27; 2.28.69). Plinius' lines, in his chapter on lions in the book about zoology, provide a powerful argument that the relationship between Antony and Cytheris was still very topical in AD. 76/77, when he wrote iugo subdidit eos primusque Romae ad currum iunxit M. Antonius, et quidem civili bello [...], non sine ostento quodam temporum, generosos spiritus iugum subire illo prodigio significante, nam quod ita vectus est cum mima Cytheride, super monstra etiam illarum calamitatium fuit (Marc Antony brought lions under a yoke and he was the first in Rome to put them to a chariot, during the civil war indeed [...]. This was not without a certain sign of those times, as this spectacle indicated that noble spirits would be brought under the yoke: riding around like that with the actress Cytheris beat even the calamities of that time). If Plinius could write this some 120 years after Antony and Cytheris went apart, it is likely that it was still a topical issue in 37 B.C.

I see in the functional reference by Horace to Marc Antony's affair with Cytheris a parallel with his criticism of Octavian in S.1.1 by means of his allusions to Virgil's Ecl.10 (see the discussion at the end of the section on S.1.1). This is an example of the use of a functional reference: triggering by a hidden allusion the contemporary reader's association with topical issues. This kind of criticism of Marc Antony was not uncommon, and I refer to Cicero's Epistulae ad Atticum and to his second book of the Philippicae. In Att.10.10.5, written in May 49 B.C., he mentions Cytheris only briefly: hic tamen Cytherida secum lectica aperta portat, alteram uxorem; septem praeterea coniunctae lecticae amicarum [eae sunt amicorum] (but meanwhile this man [Marc Antony] is carrying along with him in an open litter Cytheris, a second wife; they are joined by seven more litters with the girls of his friends). In the later book, the Philippicae, written in 44 B.C., the story about the litter returns and Cicero gives an extensive account of Antony's infatuation with Cytheris/Volumnia. As one would expect, his picture of the relationship between Antony and Cytheris in the Philippicae, written for an address to the Senate (although not delivered) criticizing his rather common habits, is rather subjective and not very positive, but the passage contains much biographical information. Cicero mentions the affair in Cic. Phil.2.24.58: inter quos aperta lectica mima portabatur [...], sed Volumniam consalutabant (amongst them a pantomime actress was carried in an open litter [...], but they greeted her as Volumnia). In Phil. 2.25.61 we read about Antony's journey to Brundisium: Venisti Brundisium, in sinum quidem et in complexum tuae mimulae (You went to Brundisium, indeed into the lap and the loving embrace of your little actress). He criticized Antony's shameful passion for Cytheris again in Phil. 2.25.62: Italiae rursus percursatio eadem comite mima (again a travelling through Italy with the same actress as companion). The latter line, however, continues with a reference to Antony's scandalous behaviour in a disgraceful orgy of pillaging of gold, silver 
and particularly of wine (in urbe auri, argenti maximeque vini foeda direptio). After his criticism of Antony's common conduct in his affair with Cytheris, Cicero refers extensively in the next paragraphs (Phil. 2.26-27) to Antony's shameful involvement in 46 B.C. at a public auction of the property of Gnaeus Pompey (Magnus) after his death in 48 B.C. In Phil.2.27.66 Cicero writes:

Incredibile ac simile portenti est, quonam modo illa tam multa quam paucis non dico mensibus, sed diebus effuderit. Maximus uini numerus fuit, permagnum optimi pondus argenti, pretiosa uestis [...]. horum paucis diebus nihil erat. (incredible and almost monstrous how much of that he squandered, not - I say - in a few months, but in days. A very large quantity of wine, a very great weight of the best silver, valuable clothes [...]. In a few days nothing of these remained).

The mimae were also present as Cicero testifies in Phil.2.27.67: alia mimi rapiebant, alia mimae; domus erat aleatoribus referta, plena ebriorum (actors carried some things off, actresses other; the house was crammed with dice players, full of drunkards). Antony's relationship with Cytheris did not finish when he married Fulvia in 47 B.C. Phil. 2.28.69, illam (mimam) suam suas res sibi habere iussit, ex duodecim tabulis clauis ademit, exegit (that actress of his he [Antony] "divorced," under the Law of the Twelve Tables he took away her keys, and drove her out) refers to Antony's repudiation of Cytheris in 45 B.C. ${ }^{97}$ I proposed above that Horace's unknown Marsaeus refers to Marc Antony. I also suggest that Horace did not express his disapproval of Antony's affair, but that Horace particularly blamed Antony's blatant and unabashed behaviour which was not fitting for a member of the Roman aristocracy. I mentioned above that Sallust in lines 47-49 pretends to be a lover of freedwomen, although he is known for his affair with Fausta, Milo's wife, who had several lovers. In lines 64-72, Horace refers to another scandal of Sulla's daughter Fausta. Two of her lovers, Villius, perhaps Milo's friend Sextus Villius, and the unknown Longaremus are mentioned. Horace saw this behaviour as typical for the degeneration of standards within the elite.

In S.1.2.73-78 one reads young Horace's words of advice:

at quanto meliora monet pugnantiaque istis

dives opis natura suae, tu si modo recte

dispensare velis ac non fugienda petendis

immiscere. tuo vitio rerumne labores

nil referre putas? quare, ne paeniteat te,

desine matronas sectarier,

97 The Latin texts are from the following sources: PLIN.Nat.8.55 is from Teubner, Mayhoff (1967, 96-97); CIC.Att.10.10.5 from Teubner, Shakleton Bailey (1987, 403), and CIC.Phil.2.24-28 from Budé, Boulanger \& Wuilleumier (1959, 120; 121; 124-125; 126). In CIC.Att.15.22, he refers to Cytheris by calling Antony noster Cytherius. Plutarch (Ant.9.4) mentions also Cytheris as Antony's mistress. For Cytheris, see also Blume (2015); Kierdorf \& Müller (2015); Schmidt (1969); Weeda (2015, 77-78); Weeda \& van der Poel (2016, 191-192). 
(but how much better is the course that contradicts this, but that nature - rich in her own way - teaches, provided that you will manage things in the right way, and not mix what must be avoided with what is to be desired. Do you think that it does not matter whether your troubles are due to your own fault or to circumstances? Therefore, stop pursuing married women, lest you will be sorry,)

Nature is rich in her resources, and thus there is more choice than affairs with married women. Kemp (2016, 139), referring to lines 73-76, remarks that "Epicurean sentiments first begin to surface," namely the poet's "recommendation to adhere to the dictates of nature." We will see below that Horace gives the Epicurean sentiments a follow-up in lines 111-116, 120-122, and 125-127. In my discussion of S.1.2.120-122, I will explain my view on Horace's motives for referring to Epicurean tenets.

In the next lines 78-105 the poet firstly summarizes his assurance that affairs with married women (matronae) only give trouble (laboris) and pain (mali), rather than enjoyment (fructus), followed by his exposition of the advantages of seeking sexual gratification with a girl in a toga (line 82 , togatae) - a prostitute or a woman, not a matrona who is available. A maid's femur aut crus (thigh or leg) are not less attractive than those of a lady. A prostitute shows openly what she has for sale (aperte/ quod venale habet ostendit, lines 83-84). Next, the poet draws an unsubtle parallel arguing that a maid can be inspected undressed whereas the matrona can show off her attractive bodily parts and hide the less attractive. Thus, seeking the pleasures of a matrona, who can seduce by only showing her attractions, is like the rich men's practice of buying horses that are covered up for inspection. Horace describes this in lines 87-89 as if he often had seen such inspections:

ne si facies ut saepe decora

molli fulta pede est emptorem inducat hiantem, quod pulchrae clunes, breve quod caput, ardua cervix.

(so that if an elegant form supported on a weak foot, as often is the case, may not lure the buyer as he gapes at how beautiful the haunches are, how small the head, and how long the neck)

In other words, the man in search of his sexual satisfaction must first see what he buys, and should better be careful. From line 94, Horace returns to the matrona and presents in lines 98-100 a catalogue of obstacles when seeking a lady of easy virtue:

custodes, lectica, ciniflones, parasitae,

ad talos stola demissa et circumdata palla,

plurima, quae invideant pure apparere tibi rem.

(bodyguards, sedan-chairs, hair-curlers, parasites, the ankle-length stola and the long wrap, very many things which deny you a clear sight of the goods) 
The next lines put it plainly: altera, nil obstat: Cois tibi paene videre est/ ut nudam (the other [togata = the prostitute], nothing stands in the way: in her Coan [see-through silk] you may see her almost as if naked). ${ }^{98}$ In S.1.2.105-110 Horace's passionate lover sings a paraphrase of an epigram of Callimachus telling that a genuine Roman lover does not want an easy lay, just as a genuine hunter follows the hare in deep snow; he does not want to touch ready game lying in his path ('leporem venator ut alta) in nive sectetur, positum sic tangere nolit'). However, the poet supposes that verses like these do not lift the torment from the lover's breast (curasque gravis e pectore pelli). One should be realistic about satisfying one's sexual desires. In line 111, Horace begins presenting his views on the best choice. He calls in nature's aid when he poses the question in S.1.2.111: cupidinibus statuat natura modum quem (what limit does nature put on desires), answering in S.1.2.113 that one should not inane abscindere soldo (separate the void from the solid). According to Gowers $(2012,113)$ "i.e. learn to distinguish illusory desires and pleasures from real ones. H.[orace]'s appeal to realism is couched in the language of Epicurean physical theory: atoms and void." The poet continues the Epicurean analogy in the next lines comparing the pains of sexual desire with hunger and thirst. When one is thirsty and hungry, a simple meal will do. Horace makes in line 113 also a significant political point referring to his Epicurean beliefs against the extreme Stoic views of Octavian's opponents.

Horace continues the discussion of the options for sexual gratification in line 116: tument tibi cum inguina (when one has a stiffy; lit. when your privates are swollen), one can satisfy the sexual hunger on the spot with a girl servant or a boy, rather than remain hungry for a lady. In S.1.2.119, Horace writes: not for me, because I like love that is readily available and an easy lay (non ego: namque parabilem amo venerem facilemque.). Venerem symbolizes that the poet expects her to be fair and beautiful. The woman who dodges him with all kinds of pretexts is not for him, but for the Galli, the castrated priests of Cybele, or for Cornelius Gallus, the elegiac poet. ${ }^{99}$

Horace quotes Philodemus approvingly in lines 120-122:

illam 'post paulo: sed pluris: si exierit vir'

Gallis, hanc Philodemus ait sibi quae neque magno

stet pretio neque cunctetur cum iussa venire.

("a little later," "it's not enough," "if my husband is not at home" - such a woman is for the Galli, says Philodemus; for himself he wants one who doesn't ask a high price, and does not hesitate to come when bidden)

Philodemus says that he wants for himself a woman who is available. He wants something between a prostitute and a married woman; is she the libertina of line 48? Horace states in the next lines some of the physical attributes he likes the woman

98 For prostitutes and their Coan dress, see Griffin $(2004,104 ; 123)$.

99 For the Gallus' suggestion, see Freudenburg $(1993,196)$. 
to have, and he closes the passage with the conclusion that when he makes love to such a woman, she changes into an Ilia or an Egeria, the arch-matrons of Rome. He says in lines 125-126 haec ubi supposuit dextro corpus mihi laevum/ Ilia et Egeria est (when she has arranged her left side under my right, she is an Ilia or an Egeria). Kemp $(2016,140)$ remarks that "these sentiments [...] may have come via Philodemus, to whom Horace has just referred."

According to Kemp (2016, 141), Horace offers these Epicurean views on sexual behaviour "in pursuance of the moderation argument." I concur with Kemp that Horace promotes the Epicurean principles because he has problems defining an acceptable mean of sexual behaviour and wants to give his appeal for moderation a philosophical foundation which he himself upholds. But, in my view, Horace has an additional reason. He shows in the present passage to Maecenas for the first time in S.1 his philosophical credentials, that is that his views on the right sexual behaviour are supported by the right philosophical conviction, Epicureanism. Maecenas was an adherent of Philodemus and Horace wanted him to know that he upheld the same philosophical ideas. I will return to this subject when I discuss S.1.3.124-142 and S.1.4, S.1.5 and S.1.6.

The lines 127-134 at the end of the poem, run like scenes of the comic theatre. The poet repeats his advice not to seek a matrona as there is always a chance of being caught out as we read in line 127: in the case of making love to an easy lay nec vereor ne dum futuo vir rure recurrat (I have no fear that, when I fuck her, a husband may run back from the country). To be caught having sex with a married woman can result in a hasty retreat, as Horace writes in lines 132-133: I must run with my tunic ungird and barefoot, for fear that I lose my money or my buttocks or at least my reputation (discincta tunica fugiendum est ac pede nudo,/ ne nummi pereant aut puga aut denique fama). The last line (134) runs deprendi miserum est; Fabio vel iudice vincam (it is terrible to be caught; however, I could prove it even with Fabius as a judge).$^{100}$ According to Gowers $(2012,117)$, Fabius, "a Stoic is presumably the chatterbox from [S.1.]1.14." Gowers poses the question whether "H.[orace] mean[s] that he has a strong enough case, enough examples (cf. [S.1.]1.13), to tire windbag Fabius out in any debate?" Her suggestion supports the view, which I mentioned above, that Horace criticizes in this poem the moral standards of Roman society, like he did in S.1.1. Fabius symbolizes the generally held view within the Roman elite that extra-marital affairs are acceptable, as "Porph.[yrio] speculates that H.[orace] cunningly shows Fabius as a supporter of the adulterer because he is one himself" (Gowers, 2012, 117-118).

Horace places the events of the second sermo clearly within the Roman upper class. He introduces many names in S.1.2. ${ }^{101}$ Although many are presumably type-

100 For Fabius, see at S.1.1.14. (see note 75). I used the rendering of Gowers $(2012,117)$.

101 Rudd (2007, 132-159) discusses many of the names in Horace's Sermones. Rudd (2007) mentions (in varying degrees of detail) Crispinus at 133; Cupiennius at 143, 145; Fufidius at 138; Galba at 143 note 
names (see Gowers, 2012 ad S.1.2), some can be identified. Horace introduces two groups of men. The first group belongs clearly to the aristocracy or at least to the political/social elite, for instance Galba (line 46), Sallust (line 48), Villius (line 64), or Longarenus (line 67) and indeed Fausta, Sulla's daughter. I incorporate also in this group Marsaeus (line 55), because I interpret him as a functional reference to Marc Antony. The second group is that of the wrong men within the retinue of Roman patrons, men like the playboy Tigellius (line 3), who was befriended to Julius Caesar, and probably fictitious Cupiennius (line 36), the mirator cunni albi (admirer of licentious matrons), or the nouveau riche like Fufidius (line 12), and the three fictitious men, effeminate Maltinus (line 25), scenting Rufillus and smelly Gargonius (line 27). The poet writes with disdain about these parvenus, which is very different from the note he strikes writing about the members of the aristocratic class, how much he may disapprove of their actions. A number of other allusions also supports the conclusion that we are seeing the upper classes in action. In lines 16-17 the moneylender Fufidius is censured for the way he treats the young sons who borrow of him; it is very likely that the vulnerable youths are sons of the elite. The second half of the poem, when Horace from line 73 depicts the risks of an affair with a married lady, does not have many names, but has a number of references to the lifestyle of the upper class. For example, in line 86 he refers to the buying of horses, in line 98 to the servants of the lady, in line 105 to the leisure pursuit of game, and finally at the end of the poem to the comic theatre, the supplier of girl friends for young gentlemen. The new rich - Maltinus, Rufillus and Gargonius - are not so much criticized for their sexual misconduct, but rather ridiculed for their common behaviour in public. Thus, although it appears that the poem concerns chiefly the pursuit of sexual extremes, I propose that Horace's commentary covers the broader field of the common and unmannerly conduct of an increasing number of members of the upper class, but particularly that of the urban nouveau riche with their materialistic attitude, their hunting for status, and lack of restraint. I quoted above Gowers (2012, 92), who hints at the theme of Horace criticizing the lifestyle of the elite when she says of Tigellius, that he "throughout epitomizes the tasteless, ostentatious prima donna (against the reticent $\mathrm{H}$.[orace]); he is also a model of inconsistency ([S.1.]3.9).” She adds in the same sentence that "the scenario [is] here, [that] international scum mourning a notorious playboy, defames the Roman patronage system.” At the time of Horace writing this sermo, a protracted development of the structure of the Roman and Italian social upper layer had materialized in new classes of rich people besides the traditional optimates, the old aristocratic families and landowners, from whom the members of the Senate and consuls were recruited. In the late second and first centuries B.C. the negotiatores - the bankers, moneylenders, merchants and manufacturers in the

29; Gargonius at 137-138; Longarenus at 137; Maltinus at 143, 148; Marsaeus at 138, 138 note 13; Rufillus at 137-138; Sallust at 135-136; Tigellius at 139, 139 note 15; Villius at 132, 136-137. 
provinces and in Italy - formed together with the aristocrats the economic mainstay of Roman and Italian society (see Brunt, 1971, 210-214; 221-222). But, "as a class the negotiatores were of little importance at Rome politically” (Brunt, 1971, 212). Further, in the first half of the first century B.C. two additional groups of men, who profited by the possibilities to make money through the expansion of the empire, emerged. These were the military men, who either managed to make their fortune in the areas where they settled after completing their time of service, or who enriched themselves by the sale of booty they stole in the wars overseas or confiscated in the proscriptions (see Brunt, 1971, 301-305; 322; Boatwright et al., 2004, 144-149). The second group was that of freedmen, who often acted as managers for the absentee landowners or as agents for the negotiatores, and of whom some gained considerable wealth. An appreciable number of negotiatores, military men, and freedmen belonged to the financial upper crust, but many of them behaved typically as upstarts, and differed from the aristocrats as they lacked their cultured upbringing and did not share the manners of the aristocracy. They were not "their sort of people," and this was very visible in their common preferences, such as a lavish, but yet "cheap" lifestyle, a lack of elegance, and an inordinate interest in matters financial.

Horace gives his view on the lifestyle of the new rich, who show their wealth in extravagant enterprises, not only in the Sermones, but also in a number of the Carmina. In the latter, he particularly criticizes the building of luxurious villas at the seaside. Carm.2.15 is the first carmen in which Horace is concerned with one of his favourite themes: a denunciation of extravagance, especially luxurious building, as the farmer is expelled and villas are erected on fertile land. The poem starts with the powerful lines: IAM pauca aratro iugera regiae/ moles relinquent (soon the hugh princely buildings will leave few acres for the plough). Carm.2.18 is again about opulent wealth, particularly in luxurious villae maritimae. Although the poem is not addressed to anybody in particular, Nisbet and Hubbard (2004, 287-290) suggest that Horace criticizes Maecenas' private wealth. The poet begins with a passage in which he describes his own modest villa and his contentment with his talents and his life on his Sabine estate. Next, Horace describes the lavish building of villae in Baiae where the houses of the rich partly extend into the sea at the cost of confiscating farmland. In Carm.2.18.20-26, the poet paints a moving picture of the evictions of the poor:

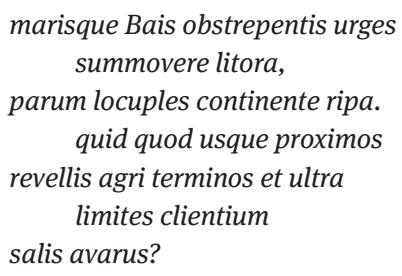

(and you push to extend the coastline of the sea at Baiae, which shouts in anger against it, because the piece of land is not sufficient as it is enclosed by the shore. How is it, that you 
continually remove the boundary stones of your neighbour's field, and that you in your greed leap over the boundaries of your tenants?)

In the fifth to eighth stanzas of Carm.3.1 Horace examines both the extravagant and greedy men who can not sleep because of their worries whereas in lines 21-22 the simple man enjoys a somnus lenis (gentle sleep), and the man who knows when he has had enough remains untroubled. We read in Carm.3.1.25-26: desiderantem quod satis est neque/ tumultuosum sollicitat mare (if one desires what is enough, the tumultuous sea does not disturb him). With these words the poet wants to tell us that "the man of limited desires is undisturbed by the bad weather that harasses the acquisitive merchant."102 The behaviour of the man who leads a simple life contrasts greatly with the arrogant man who builds his villa, not at the seaside, but in the sea. Finally, Carm.3.24, probably written in or around 27 B.C., deals with moral extravagance in different forms and the need for constraint. The carmen begins again with one of Horace's favourite subjects to which he took offence, namely the luxurious building of villae maritimae which will not take away the dread of death.

In summary, both S.1.1 and S.1.2 have a political theme besides the theme of his self-presentation. In the first sermo, Horace condemns the greed of the common people and in particular the new rich and the political instability this causes. S.1.2 has a similar theme: is not just a treatise on moderation in sexual relationships, but is much more than that. Its main theme is the poet's criticism of the vulgar conduct and materialistic attitude of the elite and nouveau riche alike, and the threat of their lack of restraint pursuing their own interests to political and economic stability. The political statements in S.1.1 and S.1.2 are part of Horace's design for the whole of book 1, which I interpret as his endeavour to show Maecenas his political reliability. S.1.1 and S.1.2 are the first examples in which he demonstrates what he stands for politically speaking.

\subsubsection{Sermones 1.3 and 1.4: From Censuring the Elite and the Nouveau Riche to a Serious Conversation with Friends}

The singer Tigellius is an obvious link between S.1.3 and S.1.2. Horace, referring to Tigellius in the opening lines of S.1.3, raises the subject of addressing an audience of friends. ${ }^{103}$ The first four lines of $S .1 .3$ read:

102 Nisbet \& Rudd (2007, 3). Nisbet \& Rudd (2007,4) argue that in Carm.3.1 "Horace rejects luxury because it does not lead to happiness, not because it is socially and politically unacceptable.” I concur with them as far as this carmen is concerned, but it does not enervate my point that Horace criticizes the elite for their pursuit of luxury and self interest.

103 For S.1.3, see Freudenburg (1993, 29-33; 39-40); Gowers (2003, 71-75; 2012, 118-147). 
OMNIBUS hoc vitium est cantoribus, inter amicos

ut numquam inducant animum cantare rogati,

iniussi numquam desistant. Sardus habebat

ille Tigellius hoc.

(this fault attaches to all singers, that when asked to sing among friends they can never be persuaded, but unbidden they never stop. That son of Sardinia, Tigellius, had this fault)

The words inter amicos in line 1 position this sermo within the protected entourage of a circle of friends, where singers or writers are more at liberty to stage when they feel like it and to say what they feel than when they have to perform in public. Tigellius is an example; Horace says in lines 4-7:

\section{Caesar, qui cogere posset,}

si peteret per amicitiam patris atque suam non

quicquam proficeret; si collibuisset, ab ovo

usque ad mala citaret, 'io Bacche!'

(Caesar [Octavian], who could have forced him [Tigellius], if he should ask him on grounds of his [Tigellius'] friendship with his father [Julius Caesar] and with himself, would get no results; but, if the fancy had seized him [Tigellius], he would not stop calling "hurra Bacchus!” from the first course to the dessert).

The reference to Tigellius' friendship with Julius Caesar and Octavian, which Porphyrio also mentions in his commentary on S.1.2.1-3, is a clear indication that Horace describes the singer Tigellius of S.1.2. Horace says in these lines that even when Octavian should have asked Tigellius to perform among friends, Octavian would not have achieved anything, if the singer did not feel like it. However, if Tigellius fancied singing, all one got was "hurra Bacchus." The implicit message of this probably fictitious story situated within the private bounds of a circle of friends is that Tigellius was a very obstinate man, and that Octavian restrained himself and did not force the singer, who was not worth listening to anyway. Gowers $(2012,122)$ remarks that this is "the only direct reference to Octavian in the book, flattering his restraint, but still a sinister hint at his [Octavian's] powers of control and censorship. Octavian took the cognomen Caesar when adopted in Julius Caesar's will in 44 BC; when H.[orace] was writing Satires I [42/41 B.C. - 36/35 B.C.], he did not yet have supreme power." ${ }^{104}$ I concur with Gowers' statement that Horace "flatters Octavian's restraint," but I differ from her point about Octavian's "powers of control and censorship" and about Octavian "not yet having supreme power." The story is set in the private domain, where powers of control and censorship can be exercised indeed. However, I understand Gowers' words "sinister hint" and those about Octavian's "supreme power" to mean that she refers to the public domain. I contend that at the time of writing S.1.3 (38/37 B.C.), Octavian did have powers of control in the public domain within the Triumvirate until 33 B.C., but

104 For Caesar, qui cogere posset, see also Griffin (1984). 
that exercising censorship was a different matter; a similar situation prevailed after 33 B.C. until 23 B.C., when under the so called "Second Settlement" his superior power was recognised and all men in office had to obey his commands. However, Octavian/ Augustus could not yet establish supreme and absolute power as he could not rely on the army, the senate and the aristocracy, whom he did not want to alienate. Thus, when Octavian gained supreme power he used that power with restraint. ${ }^{105}$ It is not clear to me whether Gowers refers to Octavian forcing Horace in 38/37 B.C. to write propaganda for him. It seems to me highly unlikely, as he in all his other Sermones (and indeed in his other work) wrote both supportive and critical poems about Octavian. Octavian/Augustus clearly condoned his critical poetry. I also do not take for granted that supportive poems are propagandist, as I define propaganda as the systematic and managed propagation of information, images or ideas by an interested party in order to encourage or instil a particular attitude or response. Propaganda generally emanates from a central source, in our case Octavian, who would maintain control of the putative propaganda machine ordering Horace to write positively about him and his policies. ${ }^{106}$

The opening passage, S.1.3.1-19 shows Tigellius' inconsistency and hypocrisy. In lines 10-15 Horace describes him as at some occasions having two hundred slaves, at other times only ten (habebat saepe ducentos,/ saepe decem servos), and at one time talking about kings and tetrarchs and everything grand (reges atque tetrarchas,/ omnia magna loquens), and at another time about the instruments of simple life such as a mussel-shell holding salt and a coarse coat to keep away the cold ('concha salis puri et toga quae defendere frigus/ quamvis crassa queat'). Horace closes this passage in lines 18-19 with the lamentation nil fuit umquam/ sic impar sibi (never was someone so whimsical). Gowers $(2012,119)$ states that "the poem might well at this point have expanded into a wider discussion of human inconsistency, but instead it turns specifically towards judgements about one's friends," as lines 19-20 show: nunc aliquis dicat mihi: 'quid tu?/ nullane habes vitia?' immo alia et fortasse minora (now someone may say to me: "what about you? You have no faults?” Yes indeed, but different and perhaps lesser ones). With the words at the end of line 20, Horace gives a jocular and relativizing reply setting the drift of the rest of the poem. In the next line he introduces two prototypes of the wrong men, with whom he would rather not associate in his circle of friends: the improbus (shameless) parasite Maenius, of good parentage but a rather self-loving spendthrift who according to Gowers $(2012,125)$

105 For a brief outline of Octavian's route to supreme power, see Weeda (2010, 25-30).

106 For Horace and propaganda for Augustus, see also Galinsky (1996, 72-73). For my definition of propaganda, see Weeda (2010, 1-2); for propaganda for Octavian/Augustus in general, see Weeda (2010, 2-4; 15-23, esp. 17-18; 48-49; 2015, 13-21). For Horace writing propaganda for Octavian/Augustus, see Weeda (2010, esp. 334-343). 
"played surrogate satirist," and the unknown upstart Novius. ${ }^{107}$ Horace brings up a putative anecdote when Maenius was asked 'heus tu'/ quidam ait, 'ignoras te?' ("ho there, you," someone said, "do you not know yourself?") (lines 21-22) which is the same question that Horace posed in line 20 (You have no faults?). Maenius is censured by Horace for his arrogant answer in line 23 'egomet mi ignosco' ("I forgive myself").

From line 25, casuistry of conduct with friends follows. S.1.3.29-37 (the passage about the clumsy satirist) and S.1.3.63-66 (Horace bursting in on Maecenas in his study) are particularly important for understanding Horace's message. In the following discussion of the poem as a whole I will focus in more detail on those two passages, which in my interpretation contain functional references to the style and manner which Horace envisages delivering his political commentary in the future. The final lines (139-142) are also an important functional reference to his efforts establishing a future position as a commentator, as he expresses his gratitude being accepted in the circle of Maecenas. Contrary to S.1.3.29-37 and S.1.3.63-66, I interpret those final lines as genuinely autobiographical. I will discuss the meaning of those lines at the end of this discussion of S.1.3.

In lines 25-37 Horace continues developing the point that it is easier to see the faults of your friends than your own. People are blind when looking at their own faults: line 25 says that they are blear-eyed, besmeared with ointment (oculis [...] lippus inunctis). Lines 27-28 conclude this part of the poem with the words: at tibi contra/ evenit, inquirant vitia ut tua rursus et illi (the result is that your friends in turn search for your faults).

I suggested above that the next passage of lines 29-37 is very important for understanding Horace's functional reference. He relates in the following lines how he wants to position himself in the book of Sermones: in the role as a gentleman commentator with some attributes of a jester. S.1.3.29-34 reads as follows:

iracundior est paulo, minus aptus acutis

naribus horum hominum; rideri possit eo quod

rusticius tonso toga defluit et male laxus

in pede calceus haeret: at est bonus, ut melior vir

non alius quisquam, at tibi amicus, at ingenium ingens

inculto latet hoc sub corpore.

(he is somewhat easily provoked, less fitted to today's condescending people; he could be laughed at because his hair is cut like that of a farmer, his toga hangs carelessly, and his loose shoe hardly clings to his foot: but he is a good man, none other is better, and he is your friend, and a great talent is hidden in that clumsy body)

107 For Maenius, see Gowers (2012, 125); Rudd (2007, 140; 293 note 17). Maenius is probably the same man as mentioned in HOR.Ep.1.15.26-41, where he is described as a scurra vagus, a doubtful buffoon. Acc. to Lewis \& Short $(1955,1650)$ a scurra is "a city buffoon usually in the suite of wealthy persons, and accordingly a kind of parasite.” For Novius, see Gowers (2012, 125). 
Horace showed in S.1.1 and S.1.2 his critical view of the conduct of the members of the Roman elite and the nouveau riche, and the threat to the stability in Italy caused by the effects of the ongoing power struggle after the end of the civil war. The latter was very visible in the land expropriations. Whereas in the first two poems he expressed a political opinion, in S.1.3.29-34 he contemplates how he should deliver such a critical political message. Horace's lines are not written by a clumsy and inexperienced philosopher and moraliser, but they present a very clever strategy as to how to conduct himself in the highly politically charged environment of the post Republican era and emerging Principate. Horace is often seen as a writer of satire and S.1.3.29-34 is interpreted as a presentation of his future style as a satirist. I read these lines differently, namely that he considers how to deliver critical commentary in general, not exclusively in the role of satirist, but that of the commentator of political issues in several genres. These lines anticipate S.1.10.46-49 in which he says that he does not intend to become the successor to Lucilius. ${ }^{108}$ The lines are a poetic way of depicting the potentially most effective manner in which to convey his critical and potentially antagonistic commentary on contemporary social and political issues: the gentleman who adopts some of the manners of a jester. This makes the passage a functional reference to the manner of presenting his commentary. I owe the idea of a gentleman jester to Freudenburg's (1993, 27-51; 72-86) discussion about the influence of the comic stage on Horace's Sermones. The crux of the above passage is in lines 31-32, where a humorous description of the poet - in Freudenburg's opinion of the poet-satirist - is given: his haircut, his untidy clothes and his loose shoes. According to Freudenburg $(1993,32)$ this description

bears direct reference to the conventions of the comic stage, rendering the satirist a bumpkin or buffoon. As a moralist, then, we would expect some rather unbalanced, self-parodic sermonizing from this character, exactly as we have it in the diatribe satires of Book 1. [...] The idea of blending the characters of the Cynic moralizer and the bumpkin or buffoon was, in all likelihood, not original to Horace but was itself the legacy of popular comedy.

In his book, Freudenburg (1993) examines the iambographic tradition. Discussing in more detail the character and role of Cynic moralizer, he $(1993,80)$ states that "the Cynic, though he resembles the buffoon in his poverty, dress, and mordant wit, differs [from the buffoon] in the intent of his jest, which serves a larger, public censorial function." I intend to demonstrate that the poet does not wish to present himself as a buffoon, as he sees such a character as uneducated and vulgar, not the sort of person he wants to get acquainted with. Horace displays his theory of commentary poetry - a mixture of Aristotelean and Hellenistic influence - fully in S.1.4. Thus, I will consider the poet's views on his own poetic programme in more detail in my discussion of

108 See also my discussion of S.1.10 in section 2.2.5. 
the fourth satire. ${ }^{109}$ At this point, I focus on Horace as a humorist. My thesis is that Horace wants to position himself as a gentleman commentator who does not shy away on the one hand from the humour and on the other from a sense of perspective. His style is not that of the professional jester of the comic stage, the scurra. Horace is in the Sermones not just simply a mixture of the seriousness of his political commentary with humour, but a mixture with a special kind of humour. ${ }^{110}$ Horace as a Cynic jester is the gentleman who can raise the most touchy issues hiding himself behind a façade of naïvety and simpleness. By this he can also make opportunity to vent the opposite or controversial political opinion, without taking sides. However, he did not keep silence in what he considered matters of crucial importance, for example his stand against Antony (and Cleopatra), particularly in S.1.7 and S.1.8. I will return to this point when I discuss S.1.6.

Freudenburg $(1993,33)$ states that "Horace was well aware of the comic tradition linking Cynic philosophers to professional jesters.” Referring to S.1.1.23-27 Freudenburg goes a step further when he says

the speaker [satirist] implies that he has sunk nearly to the level of professional jesters, the scurrae of the comic stage who earned their bread by jests and were in possession of some of the world's earliest jokebooks. Rather than deny the comparison, the mock apology actually underscores the impression that the satirist is, in essence, a comic figure.

I differ from Freudenburg that Horace intends to say that "the satirist is, in essence, a comic figure." Of course, one finds humour in Horace's work, which is the result of the way he delivers his commentary by the persona of the comic jester. And there is certainly self-parody in the first book of Sermones - for example in this poem: S.1.3.29-37 (the passage about the clumsy satirist), S.1.3.63-66 (Horace bursting in on Maecenas in his study).

In lines 38-54, Horace returns to the subject of understanding one's friends. He refers to a lover's (Balbinus') blindness to the faults of his girl Hagna (S.1.3.38-42), and a father's tenderness about the disfigurements of his child (S.1.3.43-48). ${ }^{111}$ In the last six lines of this section (S.1.3.49-54), one reads examples as to how friends' faults can also be understood positively, and thus friendships can be strengthened. For example, lines 38-40 read: amatorem quod amicae/ turpia decipiunt caecum vitia, aut etiam ipsa haec/ delectant (that a lover, as he is blind, is deceived by the ugly defects of his girl, or is even pleased by them). In lines 43-44 Horace says at pater ut gnati sic nos debemus amici/ si quod sit vitium non fastidire (as a father [does not loathe the imperfections] of his son, so we ought not to be scornful of a friend's fault, if there is

109 For Horace's theory of censure poetry, see Freudenburg (1993, 96-108).

110 See also Freudenburg (1993, 81-82); Leach (1971, 623-624; 629). For a detailed discussion of the scurra in Latin literature, see Corbett (1986); see also note 107.

111 For Balbinus and Hagna, see Gowers (2012, 128-129). 
any). In S.1.3.44-48, the poet gives four examples of parents' tolerance of children's imperfections. This is followed in lines 49-54 by four examples of forbearance to faults of a friend, for example in line 53 caldior est: acris inter numeretur (is he a hothead? consider him energetic). Horace argues in lines 53-54 that by emphasizing the positive side one makes friends and keeps them: opinor,/ haec res et iungit iunctos et servat amicos (in my opinion, this is how one makes friends and when made keeps them).

From S.1.3.55, Horace approaches the theme of the human inclination to judge people negatively from the opposite angle, that is that virtues are also often seen as faults. He opens this section by saying: at nos virtutes ipsas invertimus atque/ sincerum cupimus vas incrustare (but we misrepresent virtues themselves, and we want to besmear a clean vessel); according to Gowers $(2012,131)$ the metaphor refers to the soiling of a clean winejar and means that "we 'upturn' [invertimus] merits to make them into faults;" in other words, that man readily sees positive characteristics as negative traits. In lines 56-58 he gives an example:

(there lives among us a honest man, a very unassuming man: him we give the nickname slow, stupid)
}

Next, in S.1.3.63-66, he presents a second self-parody, a "character sketch of a gauche intruder, which gradually comes into focus as another self-deprecating portrait of H.[orace] and his relationship with Maecenas.” (Gowers, 2003, 72-74; 2012, 132). Freudenburg $(1993,29)$ interprets the passage somewhat differently: he argues that "the suggestion [made by Armstrong $(1989,37-41)$ that in S.1.3 Horace describes himself] is attractive, for this is just the type of behaviour we have come to expect of the speaker, who is something of a social menace.” I concur with both Gowers and Freudenburg interpreting S.1.3 as a description of Horace himself, but I differ from them about Horace's self-portrait. Horace does not depict himself as either a clumsy provincial bumpkin or as a social menace. I suggest that this passage is a sequel to S.1.3.29-34, and a precursor to S.1.3.90-94; these are all passages in which he presents himself as a gentleman jester who takes the liberty to tell Maecenas whatever he thinks that the latter should hear, and that Maecenas knows how to handle those people. ${ }^{112}$ S.1.3.63-66 reads:

simplicior quis et est qualem me saepe libenter obtulerim tibi, Maecenas, ut forte legentem aut tacitum impellat quovis sermone molestus:

112 The theme of how Maecenas associates with the members of his circle also returns in Horace's reply in S.1.9.48-52 to the pest whom he meets in the Via Sacra. 
'communi sensu plane caret' inquimus.

(or there is one who is rather simple, the way I would often gladly show myself to you, Maecenas, as he breaks in upon you perhaps while you are reading or in thought and annoy you with one or other chat: we say "he is clearly without consideration.")

The words qualem me saepe libenter obtulerim tibi, Maecenas is a direct reference to Horace's conduct in the relationship with Maecenas. Horace concludes the scene, in which he bursts in on serene Maecenas reading and thinking, with the words "communi sensu plane caret" inquimus. These words are an ironical disapproval of the facetious conduct of the jester, who suggests that he can afford almost anything, knowing that Maecenas will accept such behaviour, as masters of jesters do. Like the earlier passage (S.1.3.29-34), this one is not autobiographical, but a further specifying of the way Horace intends to present his messages in the first book of Sermones, and thus provides again a functional reference to his future style.

From line 68, Horace continues the theme of the meaning of friendship and the conduct among friends. No man is born without faults (nam vitiis nemo sine nascitur), but there should be give and take. Lines 69-72 say:

amicus dulcis ut aequum est

cum mea compenset vitiis bona, pluribus hisce -

si modo plura mihi bona sunt - inclinet, amari

si volet

(a dear friend, if he is fair, should weigh my qualities against my faults, and be favourably disposed towards the more numerous - provided that my qualities are the more numerous - if he wants to remain friends)

When one looks for the balance (aequabilitas) both ways, friendship will continue. In the passage starting at line 76 , the argument moves away from the single theme of tolerance of the faults of one's friends. Horace introduces also the theme of balance (or the lack of it) in the execution of justice in society at large. The argument also moves gradually towards one with a philosophical and a historical angle (lines 99-124). Horace argues that the Stoic view that all sins are equal and deserve equal punishment is absurd. He gives examples of what he considers an excessive sanction for a minor misdemeanour. Horace appeals for reason (ratio) and balance (ponderibus modulisque) in lines 77-83:

curnon

ponderibus modulisque suis ratio utitur, ac res

ut quaeque est ita suppliciis delicta coercet?

si quis eum servum patinam qui tollere iussus

semesos piscis tepidumque ligurrierit ius

in cruce suffigat, Labeone insanior inter

sanos dicatur.

(why does reason not use her own weights and measures, and holds in check offences with punishments according to each case? If someone should crucify a slave who, when ordered to 
remove from the table a dish, feasted by stealth on the half-eaten fish and its cold juice, he would be called more insane than Labeo by sane men)

Horace displays in line 78 in a subtle way his Epicurean disposition with the choice of words ponderibus modulisque (weights and measures). Contemporary readers of these words would readily associate those with the Epicurean tendency to quantify and measure. The anti-Epicurean Cicero argued against this at many places, because he saw this tendency to measure everything as motivated by self-interest and as an inducement to avoid political involvement. ${ }^{113}$ I noted already in section 1.1 (General Introduction), that Horace in the last lines of this sermo expresses his gratitude being accepted in Maecenas' circle, and in S.1.5 and S.1.10 his appreciation of being admitted to an intellectual milieu of men with Epicurean leanings, of whom many did not shy away from political involvement. But, apart from showing his gratitude, Horace makes another point. By quoting the words ponderibus modulisque, he also shows Maecenas that he holds the right philosophical convictions. Horace's references to Stoic and Epicurean tenets in S.1.3 will be further considered below in my discussion of scholars' commentaries on S.1.3.76-124.

If someone were to crucify a slave for the minor misdemeanour of licking up the remains of a meal, he is worse than Labeo, who lost all sense of proportion trying to punish Metellus. Although the crucifixion of the slave is bad, Horace argues in lines 83-86 that rejecting a friend for a minor fault is even worse:

quanto hoc furiosius atque

maius peccatum est! paulum deliquit amicus,

quod nisi concedas habeare insuavis: acerbus

odisti et fugis ut Rusonem debitor aeris

(how much madder and worse a sin is this! A friend has committed a minor fault, which, if you do not pardon it, will make you to be seen disagreeable: you [start to] hate him bitterly and keep away from him like a debtor keeps away from Ruso)

Horace likens the intensity of someone's grievance over a friend's rejection for a minor fault to the feelings caused by the bitter hatred felt for Ruso by a poor debtor unable to raise the money to pay off his debts. ${ }^{114}$ The latter keeps away as much as possible from Ruso, an unknown moneylender with literary aspirations, who forced

113 For Cicero and Epicureanism, see Hanchey (2013). Cicero discusses the association between Epicureanism and the tendency to measure in amongst others Leg.1.39, de Orat.3.285, Fin.2.85, Fin.5.93. For Cicero's views on avoidance of political involvement, see my discussion of S.1.6.111-128, the passage about a typical day in Horace's life.

114 Acc. to Gowers (2012, 135-136) the Labeo referred to is most likely “C. Antinius Labeo, a Republican tribune of the plebs who tried to punish Metellus for rejecting him from the senate by ordering him to be thrown from the Tarpeian rock in 131 B.C.” For Labeo, see also Rudd (2007, 136-137; 137 note 11). For Ruso, see Gowers (2012, 136); Rudd (2007, 134). 
his victims to listen to his boring stories. Horace - like a true jester - exaggerates that such a rejection of a friend is worse than the fate of the crucified slave. Next, Horace mentions more examples of offences among friends in order of increasing gravity, from harmless infringements of table manners to more serious delicts by friends such as theft or reneging on a legal pledge. He poses the rhetorical question in lines 94-95 quid faciam si furtum fecerit, aut si/prodiderit commiss a fide sponsumve negarit? (what to do if he [a friend] commits a theft, or if he betrays perfidiously a trust, or reneges on a legal pledge?). In the lines that follow he says (line 96) that the answer of the Stoics that all sins are nearly equal (paria esse fere [...] peccata) does not work in reality. Emotions, the moral sense of people, and custom are opposed to it (sensus moresque repugnant) (line 97). He concludes with the statement that justice and fairness are sisters.

In the following passage of lines 99-124, Horace turns again to Epicureanism to expound his views on the history of civilization and the origin of justice and fairness in contemporary society. In primeval times humans and beasts were very much alike: in lines 100-102 Horace depicts the first living creatures as follows: mutum et turpe pecus, glandem atque cubilia propter/ unguibus et pugnis [...] pugnabant (dumb and ugly beasts, they fought for their acorns and dens with nails and fists). Then, technology advanced and man learned to speak; lines 103-105 read:

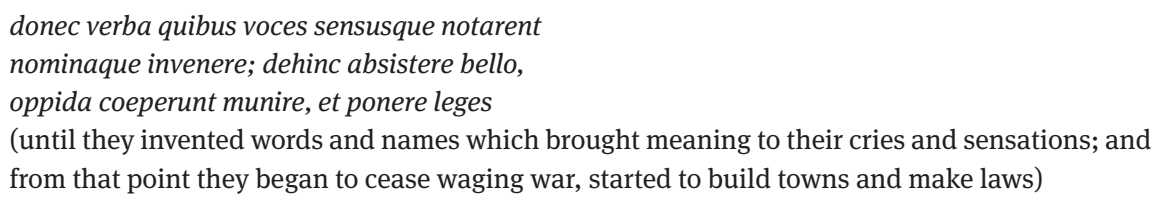

Horace considers the learning of speech a turning point in human development: man ceased acting according to the law of the jungle like the cave-men they were before, when fights over women were common, although not yet immortalized by Homer. In lines 107-108, he reminds us that the Trojan war was only recently fought by civilised men over Helen's adultery. Next (lines 111-117), Horace testifies his belief that the perception of right and wrong is not natural to man, and he states in line 111: iura inventa metu iniusti (justice was invented through fear of injustice). ${ }^{115}$ In line 115, Horace returns to the Stoic doctrine that all sins are nearly equal, to which he referred in line 96. In accordance with Philodemus' teaching in De ira, he suggests again that the severity of the penalty should correspond with the seriousness of the offence. He writes in lines 117-119 adsit/ regula, peccatis quae poenas irroget aequas,/ ne scutica dignum horribili sectere flagello (let there be a rule that imposes penalties which fit the crimes, so that you do not apply the terrible whip to what only deserves the strap).

115 See also Keane $(2006,87)$. 
Scholars' commentaries on the passage S.1.3.76-124 focus on several aspects. Gowers $(2012,120)$ argues firstly that in this passage "a plea for tolerance" is presented, and that "behind this plea for tolerance lies recognition of the threat being posed to individual autonomy in contemporary Rome." Her second argument concerns the view that "the social contract [law in society] is presented [by Horace] as an expedient devised for mutual benefit, rather than as an innate instinct." In addition, she states that "one way to explain the chosen priorities of this history [of civilization from cavemen to the modern day in lines 99-112] is to see it as a carefully contrived parallel to H.[orace]'s own evolution.” Keane (2006, 52-53; 86-87) emphasizes Horace's view (in lines 96-106) on the development of a system of justice "asserting that human culture (not nature, as the Stoics hold) has devised sensible laws for dealing with a range of offences" (Keane, 2006, 52). She (2006, 53) notes that "Horace's evolution narrative has implications for his self-presentation as satirist.” Keane $(2006,87)$ also argues that the poet in this passage, which she sees as a "climax to the first three poems of Sermones 1, [...] does begin to explain satire's status as a iustum poema." Kemp (2009) focusing on the philosophical foundation underlying this passage asserts that Horace links balance with moderation to promote his own view of friendship, rejecting the Stoic rigidity. Finally, Freudenburg (1993, 26-27) questions whether S.1.3.96-124 should be read as one of Horace's philosophical arguments. He $(1993,26)$ states that the passage "is intended as a parody of Epicurean doctrine, a 'mock history of the social contract,' not as an effective argument against the Stoics.” He (1993, 26 note 67) accentuates this when he says: "Noting the broad philosophical range of many such passages and the apparent irony of others, it is very difficult to make a case for Horace's Epicureanism on the basis of the diatribe satires."

In my view, Horace argues in lines 99-124 that the system of justice is the crown of the development of a civilized society and that tolerance, balance and wisdom should be essential elements of such a system. This leads him to the question of the choice of men who should be the leaders in society. Horace places in this passage acceptance of or intolerance to friends' faults and also extremism in the execution of justice within the context of Stoicism and Epicureanism. We will see below that he connects his commentary with the emergence of new men within the political elite, who are driven by personal gain. The references to Stoic and Epicurean tenets in S.1.3 are rather plain philosophy, and are not part of a philosophical discourse. ${ }^{116}$ My thesis is that these philosophical quotations are functional references. What matters are not just Horace's statements about friendship, tolerance, fairness, or balance, but more important are the men who make those statements or the men to whom Horace refers. Below, I will explore the social and intellectual standing of the men whom Horace quotes about both the issue of intolerance to friend's faults, and the issue of the absurd and severe punishments for small misdeeds. The wrong men, upstarts have gained too much

116 For Horace's handling of Epicurean and Stoic philosophy, see also Kemp (2010, 73 note 28). 
influence. I will analyse later the contribution of each individual mentioned in this sermo.

I will first discuss the final section of the poem, lines 124-142, in which Horace ridicules the Stoic paradox that only the wise man (sapiens) is perfect and thus rich, free, beautiful and talented. Horace plays a very clever game in this passage. He does not only hold up to ridicule the paradox, but also censures the Stoics for the results of the paradox in the choice of leaders and thirdly he can, as an extra benefit, demonstrate to Maecenas, that they share the same philosophical framework thus subscribing to the same views on political matters. Horace plays in S.1.3.124-142 three times upon a word to caricature the Stoic paradox. The first is sutor (cobbler) in lines 125 and 128, the second modulator in line 130, and the third is tonsor (barber) in line 132. ${ }^{117}$ S.1.3.124-133 reads:

\begin{abstract}
si dives, qui sapiens est,
et sutor bonus et solus formosus et est rex, cur optas quod habes? 'non nosti quid pater' inquit 'Chrysippus dicat: sapiens crepidas sibi numquam nec soleas fecit; sutor tamen est sapiens.' qui?

'ut quamvis tacet Hermogenes cantor tamen atque

optimus est modulator; ut Alfenus vafer, omni

abiecto instrumento artis clausaque taberna,

tonsor erat, sapiens operis sic optimus omnis

est opifex solus, sic rex.'

(if the wise man is rich, and a good cobbler, and only handsome and a king, why do you desire to possess what you have got already? He [the Stoic] answers "you do not understand what father Chrysippus means. The wise man has never made himself shoes or sandals. Yet, the wise man is a cobbler." How? [The Stoic says] "Just as Hermogenes, although he is silent, is is still the best singer and musician; and just as shrewd Alfenus, after throwing away all the tools of his trade and closing his shop, was still a barber. So only the wise man is the best artisan at every craft: he is king.")
\end{abstract}

The sapiens is caricatured by the poet in lines 124-128 as being an expert cobbler (sutor). The Stoic's response to Horace's quip in lines 127-128 is: 'sapiens crepidas sibi numquam/ nec soleas fecit; sutor tamen est sapiens' ("the wise man has never made himself shoes or sandals. Yet the wise man is a cobbler"). The Stoic suggests that the sapiens is potentially an expert in all things. ${ }^{118}$ One may wonder why Horace chose the humble trades of cobbler, and indeed in line 132 that of barber, for making his point; both trades were low in the social scale. In my view, Horace not only wanted to express the absurdity of the potential of the opportunities for the wise man in the Stoic paradox, but also wanted to play upon the words sutor and tonsor. That is why

117 Meyer (1874, 206 = Porphyrio) gives in line 132 sutor i.s.o. tonsor.

118 Conform Brown (2007, 125); Gowers (2012, 144). 
he says in line 128 with great emphasis sutor tamen est sapiens (Yet, the wise man is a cobbler) and in lines 132-133 'sapiens operis sic optimus omnis/ est opifex solus,' ("so only the wise man is the best artisan at every craft”). Firstly, I will discuss my views on Horace's use of sutor in lines 124-128, and next I will consider Freudenburg's (1993, 114-117) views on modulator and tonsor in lines 128-133; the idea that the poet's use of sutor was a similar case occurred to me by the latter's interpretation.

Horace plays upon the word sutor, that is generally translated as cobbler. Sutor is derived from suere, to stitch or cobble. The latter word suggests patching-up something, working hastily and delivering shoddy work. In other words, Horace says that the Stoic's claim is absurd and that they make a mess of things: the Stoic view leads to the selection of the wrong people for high positions in public life, as we will see in the discussion of lines 128-133 (Freudenburg's view). What else do the Stoics mess up? The extreme Stoics, anti-Caesarians and followers of the Pompeian cause, stood in Octavian's way and obstructed the latter's progress towards peace and stability. ${ }^{119}$ In particular, Horace has in mind the war waged at the time by Sextus Pompey, which stretched out the civil war.

In lines 129-130, Horace introduces Hermogenes, who is in S.1 the successor to Tigellius for Horace's wrath. We saw at our discussion of S.1.2.1-3 that he is "the second man," removing the dilemma of the Tigellius/Hermogenes identities. The fact that Horace presents him at this stage plainly as Hermogenes is an additional indication that he is somebody who is separate to Tigellius, whose funeral opens S.1.2. Freudenburg (1993, 114-117) examines Horace's references to Tigellius/Hermogenes in the Satires, and presents an interesting view on the poet's use of the word modulator. He remarks that the noun cannot only connote a songwriter, but he $(1993,115)$ also suggests "that the term carries the sense of an 'improviser,' that is, one who is able to measure quickly or 'adjust' his song." In the words of Freudenburg (1993, 116), Hermogenes of line 129 has a "remarkable ability to 'change keys' or 'adjust' himself to the changing political winds of the late Republic.” DuQuesnay $(1984,56)$ considers the possibility that Hermogenes defected to Sextus Pompey, which gives Horace's words a major contemporary political weight. ${ }^{120}$

I repeat lines 130-133 which I quoted before, where the Stoic presents a second person to prove his paradox, Alfenus. The lines read:

'ut Alfenus vafer, omni

abiecto instrumento artis clausaque taberna,

tonsor erat, sapiens operis sic optimus omnis

est opifex solus, sic rex.'

119 Conform DuQuesnay (1984).

120 For Hermogenes in S.1.3.129-130, see also Gowers (2012, 144), who interprets Tigellius in S.1.2.3 and Hermogenes as the same individual. 
("and just as shrewd Alfenus, after throwing away all the tools of his trade and closing his shop, was still a barber. So only the wise man is the best artisan at every craft: he is king.")

According to Freudenburg, the lines refer to P. Alfenus Varus, consul suffectus in 39 B.C. and jurisconsult. He argues that the lines should not be interpreted literally meaning that Alfenus Varus was indeed a barber before becoming a lawyer. Freudenburg (1993, 51) points out that at Plautus and Terence tondere also "connotes deceit and intrigue, in the sense of to fleece, or rip off." ${ }^{21}$ Thus, the lines can be read as "Alfenus, even though he has sold his shop to become a lawyer, is still the same old shearer [that is, crook] that he always was." I concur with Freudenburg's novel view on Horace's use of the word tonsor in the case of Alfenus. However, contrary to the use of the word modulator in the case of Hermogenes, he examines tonsor within the context of stylistic theory. I interpret the use of the word tonsor in the first place as a reference to political issues.

It is not possible to identify Alfenus with certainty. According to Gowers (2012, 144-146), the name possibly refers indeed to P. Alfenus Varus, but a second option is P. Alfenus, who was legatus pro praetore in Achaea in 39 B.C. In my opinion P. Alfenus Varus is the most likely candidate. Horace wrote the third satire between $38-36 / 35$ B.C., the same period in which Virgil wrote the Eclogae. Further, Horace and Virgil knew each other, and it is feasible that Horace knew Virgil's Ecl.9, written in 41-40 B.C. In Ecl.9.27-28 Virgil refers specifically to Alfenus Varus and the events in Mantua in 41-40 B.C.: 'Vare, tuum nomen, superet modo Mantua nobis,/ Mantua uae miserae nimium uicina Cremonae' ("Varus, your name, let but Mantua remain for us, Mantua, alas, too much in the vicinity of unfortunate Cremona [the birthplace of Alfenus Varus]"). In addition to Virgil, three ancient testimonies about Varus' involvement in the land expropriations in Northern Italy have come down to us: Donatus in his Commentarii Vergiliani (in Eclogas).13 (on Ecl.9), Servius in his commentary on VERG. Ecl.9.10 quoting “a passage from a speech by 'Cornelius' (presumably Gallus) against Varus” (Wilkinson 1997:31), and Suetonius in Vita Vergili.19. ${ }^{122}$ The latter testimonies

121 For the identification of Alfenus, see Freudenburg (1993, 50-51); Gowers (2012, 144-146); Rudd (2007, 136-137). Rudd (2007, 137 note 8) states that Alfenus being identical with Alfenus Varus "is the traditional view [...]. Such an eminent contemporary, however, seems rather out of place in this satire." I concur however with Freudenburg $(1993,51)$ who argues that "the Alfenus joke, like the reference to Balbinus at Satires 1.3.40, illustrates the working of the comic analogy at its very subtlest and best." For the use of tondere in Plautus, see also Fantham $(1972,103)$.

122 For the involvement of Alfenus Varus in the expropriations in Northern Italy, see also: Clausen (2003, 181); Jenkyns (1998, 170-171); Patterson (1987, 31-34); Wilkinson (1966, 320-324; 1997, 29-31); Hermes (1980, 212-257), who quotes the opinions of several scholars before 1977. For the involvement of high-ranking men in the expropriations, see Weeda, (2015, 56-57; 73-74); Weeda \& van der Poel (2016, 202-203). For the text of Donatus, see www.intratext.com: et per triumviros agris dividendis Varum, Pollionem et Cornelium Gallum (and the three joint commissioners for the land division Varus, Pollio and Cornelius Gallus). The passage by Servius on Ecl.9.10 (Thilo, 1887, 110) reads as follows: 
make it very likely that Alfenus was involved is some way or another, not necessarily in individual cases. For example, I argue in my book on Virgil's political commentary that it is doubtful whether Cornelius Gallus, Varus and Pollio were involved in the actual expropriations in the Mantua area and that Cornelius Gallus mediated between Virgil and Alfenus Varus, in an attempt to exempt the entire area of Mantua from confiscation. I quoted Bowersock $(1971,76)$ that "the scholia [Servius and Donatus] are worthless evidence for details of the land commission, and so is Virgil. That can only redound to the poet's credit. He has caught a mood, an atmosphere in his poems." Although the scholia may be unreliable with respect to the details of the land expropriations and although there is no independent confirmation of the precise involvement of the officials and the scholiast had presumably no other source than the poems, it does not necessarily imply that Varus was not involved in some way. Still, Virgil introduced certainly historical individuals, Alfenus Varus (Ecl.6.6-12 and Ecl.9.26-29) and Gallus (Ecl.6.64 and Ecl.10.1-10, Ecl.10.22-23 and Ecl.10.72-73) and indirectly even Octavian (Ecl.1.42-43). It is not clear whether Virgil (or his family) personally lost property in the expropriations, but it appears from a number of Eclogae (1, 6, 9 and indeed 10) that he was very well acquainted with what was going on. ${ }^{123}$ I (Weeda \& van der Poel, 2016, 203) suggest that Virgil used the names of Varus, Pollio and Gallus to symbolize the actual involvement of high-ranking officials, without specifying exactly who was involved where. Although Virgil's poetry contains references to real events, it does not offer historical precision. ${ }^{124}$

It is feasible that Horace in S.1.3 copies Virgil and that the references to Hermogenes and Alfenus symbolize the many who tried to force their way into the

per iniquitatem Alfeni Vari, qui agros divisit (because of the unreasonableness of Alfenus Varus, who divided the lands). For the text of Suetonius, see Rostagni (1944, 84). The passage by Suetonius is: maxime ut Asinium Pollionem, Alfenum Varum et Cornelium Gallum celebraret, quia in distributione agrorum, qui post Philippensem victoriam veteranis triumvirorum iussu trans Padum dividebantur indemnem se praestitissent (particularly to praise in song Asinius Pollio, Alfenus Varus, and Cornelius Gallus, because - at the time of the distribution of the land, which beyond the Po was divided by order of the triumvirs among the veterans after the victory at Philippi - these men had saved him from the loss of his land).

123 For Alfenus Varus in Ecl.6, see Weeda (2015, 56-57; 65), and in Ecl.9, see Weeda (2015, 55-57; 7374); see also Weeda \& van der Poel (2016, 203). Jenkyns (1998,169-172, at 171): "Certainly he [Virgil] is concerned for the distresses of his fellow countrymen, the Mantuans - so much is explicit - and to that extent personal experience enters into his allusions to the confiscations; and of course it remains possible that he himself lost some land, possible even that Caesar restored it, or compensated him in some other way. But that is pure speculation, nothing more; Virgil does not suggest this to us, either directly or by implication." (my emphasis).

124 Gold (2012b, 305) makes a similar point writing about patronage and the dramatis personae in a poem: "Is Propertius [for instance] describing an historical figure when he addresses Maecenas at some length in poems 2.1 and 3.9, [...], or is Maecenas transmuted into a symbol of important ideas in Propertius' poetry?" 
social and political elite. This theme returns in S.1.9, the story about the meeting with the nuisance when Horace strolled along the Via Sacra. The poet did not intend to make in S.1.3 a philosophical statement about the wrong of the Stoic ideal that the wise man (sapiens) is perfect and talented. The three keywords, sutor, modulator and tonsor, all point in the same direction: he had in mind to demonstrate by a functional reference that men like Hermogenes, who exemplifies unreliability, and Alfenus, who shows untrustworthiness and dishonesty, should not be welcome into the political and social elite, and are not deserving to hold office: Hermogenes who defected to Sextus, and Alfenus Varus who was "ripping off" the poor smallholders in Northern Italy. He emphasizes the moral and intellectual failure of the Stoic paradox once more by the pitiful picture in lines 133-139, when in the words of Gowers $(2012,145)$ : "grandiose theory becomes ragged reality." Horace depicts the Stoic philosopher on his way to have a bath on the cheap (quadrante is the customary price of a bath in a public place) mobbed (urgeris) by a hostile crowd of men (turba), with whom the poet does not wish to be associated. The escort of the wise man, alias king, is only Crispinus the babbler whom we met at the end of the first sermo.

We saw in the passage of lines 124-142 that Horace used his philosophical conviction to deliver his commentary on - what he sees as - social and political evil. In addition, the commentary enabled him to show Maecenas that he had the right political convictions to be a member of his circle of friends. The evidence of the interrelation between on the one hand Horace's philosophical and on the other his political views can be seen at several places in S.1.1-1.3. For example, right away from the start in the first part of S.1.1 he refers (S.1.1.13-14) critically to the Stoic Fabius, thus rejecting the favourite philosophy of the political opponents of Octavian, the Republicans and Pompeians. Horace demonstrates immediately in S.1 what he stands for, that is support for the cause of Octavian. Further, he infers in S.1.1.15-22 that Stoic philosophy is not the only guide to responsible behaviour, but that the old Roman traditional values can well be an alternative; in political terms this can be seen as an appeal for the preservation of the traditional social structures and for calling a halt to the progress of the greedy new rich. Next, we saw that in S.1.2.111-134 Horace's plea for realism in love affairs is couched in the language of Epicurean physical theory (e.g. in line 113 inane abscindere soldo, atoms and void). The political point is that he connects this Epicurean idea with what he sees as the degeneration of standards in Roman upper classes, that is the threat to political and economic stability by their lack of restraint pursuing their own interests. In S.1.3.96-98 Horace rejects the Stoic view that all sins are equal. He argues that this does not work in society. His Epicurean socio-political attitude causes him to state that justice should be organised in such a way that it goes together with fairness. We saw that Horace ridicules the Stoic paradox in S.1.3.124-142; politically speaking this means that he castigates the republicans who with their Stoic beliefs tend to despotism. One further example where Horace's Epicurean conviction lies at the root of his political view is in S.1.6.111128, the passage about a typical day in Horace's life. He seeks to participate in politics 
as a commentator. His Epicurean views make him aware that he needs the freedom to organize his life in his own way to be able to reflect and study.

Horace introduced many people in this poem, who can be divided into two groups. The first group is that of his friends, whom the poet quotes consistently in a positive manner in this sermo. For example, he refers to Octavian and Maecenas: in both cases he writes with appreciation. Horace compliments Octavian in line 4, and I do not read any criticism of putative supreme power exercised by him. The contexts of the passages where he refers to his relationship with Maecenas (S.1.3.29-37, S.1.3.4975), and with his friends (S.1.3.139-142) are all positive descriptions of the benefits of friendship. In other words, Horace's aristocratic friendships are models of amicitia. The second group shows the opposite image with the names of the inconsistent singer Tigellius (line 4) and unreliable Hermogenes (line 129), shameless Maenius (line 21), a spendthrift from the past, the upstart Novius (also line 21), deranged Labeo (line 82), a Republican tribune of the plebs, Ruso, a moneylender and aspiring author (line 86), and Alfenus (line 130), most likely corrupt P. Alfenus Varus. It is worth noting that everybody who discusses how to judge one's friends - apart from Alfenus Varus - fits the category of new rich or other upstarts. Further we meet the Stoic Chrysippus (line 127), who is gently mocked, and finally there is Crispinus (line 139), the Stoic babbler. They generally take the "wrong" view as to how to treat one's friends, support Stoic ideas about the execution of justice resulting in excessive punishments for minor offences. When Horace compares friendship with love (S.1.3.38-48) showing the affectionate attitude of the lover for his beloved or of the father for his child as paragons for real friendship, the names which are introduced are impossible to identify. Unknown Balbinus, presumably referring to a wheedler, and the only woman Hagna (a common freedwoman's name) in line 40 cannot be identified.

Horace closes S.1.3 with a few lines (139-140) about his own fortunate circumstances. DuQuesnay $(1984,36)$ also argues that Horace at the end of this poem refers to himself: et mihi dulces/ignoscent, si quid peccaro stultus, amici (and my dear friends will forgive me if I - fool I am - make a mistake). He was accepted within a circle of men of great charisma and importance, real friends. Gowers $(2012,147)$ mentions only in passing that "DuQuesnay 1984:36 reads a political appeal into these words.” DuQuesnay states that “among his [Horace's] amici were Caesar (Octavian) and Maecenas; among the faults which they pardoned, the reader will recall, Horace's adherence to the Republican cause at Philippi." I am much in sympathy with DuQuesnay's view; I read the poet's words as confirming that he felt accepted within Maecenas' circle of civilised men. We will see that Horace shows his positive feelings about his position in the circle of Maecenas again at a very symbolic place at the end of the first book, S.1.10.81-90. He acknowledges many of his learned and his poet-friends, as well as Octavian, Maecenas and Messala among other politician friends, whose praise of him and his poems he values most.

The manner in which Horace conducts this discussion, his choice of participants and subjects, suggests that there is an (anti-Stoic) philosophical side to the poem. 
Although at one level S.1.3 concerns indeed the conduct among friends - specifically the judgment about the inconsistency and hypocrisy of one's friends - I suggest that the poem also contains a second point, that is how a message can be presented within a circle of friends, while at the same time preserving tolerance and dignity among the participants. In the next sermo, the fourth, Horace develops his ideas on the standards required for his future commentary on political issues to three distinct groups: the political elite, the nouveau riche and his friends.

DuQuesnay also sees a philosophical/political content in S.1.1-1.3. The poems show the Epicurean foundation of Horace's philosophical conviction and a rejection of Stoicism, the popular philosophy of those who supported the Republican cause. In DuQuesnay's $(1984,33)$ opinion, Horace wants to show that "the Stoics and the Pompeians have no monopoly of concern with morality.” The Republicans and Pompeians adopted the widely held opinion at the time that the Triumvirs - and Octavian and his associates in particular - did not act from high moral principles at all but from avaritia, ambitio and luxuria, which were seen as the cause of Octavian's hunger for power resulting in the battle of Philippi, the Perusine War and the land expropriations. In the three sermones, Horace shows his concern about the growth of reprehensible urges like greed, unlimited ambition, pursuit of luxury and uncontrolled sex. He suggests that Octavian, Maecenas and his friends share his concern. S.1.1-1.3 also have an additional political aspect, namely that Horace divides the internal audiences (Gold's terminology, see discussion in section 2.1) of his sermones in three distinct groups, the elite, the nouveau riche and the extreme Stoics. He singles out some of the aristocrats and the nouveau riche and other upstarts as unfit for political office, and he condemns those followers of extreme Stoicism, who belong to the Republican and Pompeian camp. Thus, the three sermones are political poems as they are in support of Octavian and his policies against the Republican adversaries. His circle of friends ought to set a good example by living according to the high-minded principles of the past. ${ }^{125}$

Looking at S.1.1-1.3 from a different angle altogether, they divide into two groups: on the one hand S.1.1 and S.1.2, and on the other S.1.3. The two groups differ in the following way: Horace focuses in the first two poems especially on the impropriety and misbehaviour of the political elite and the new rich in matters of general conduct in society, such as greed, unlimited ambition, and uncontrolled sex, while he is less concerned with the method of his delivery of the poem. In the third sermo, however, his focus is much more on the conduct within a circle of friends, while the method of presenting the message gets more attention than in the first two poems.

125 For the political content in S.1.1 - 1.3, see DuQuesnay (1984, 27-36). 
In S.1.4, Horace continues the theme of the third sermo, namely how to conduct oneself in a civilized, but critical conversation about political issues. ${ }^{126}$ Horace presents in the first four sermones a well argued view as to how he intends to write politically oriented poetry, that is that he submits his ideas with respect to three fields of his intended authorship: the style, the subject matter, and the targets of his critical poetry. In this sermo, he defines first his style in lines 1-62. Thus to begin with, I will focus on his ideas about style. I will consider the subject matter and the targets in more detail at the end of my discussion of S.1.4 also taking full account of what we have seen in the first three sermones. Further, it should be noted that many of the issues dealt with in S.1.4 return in S.1.10. Therefore, in the discussion of the latter sermo I will frequently refer back to S.1.4.

Significantly, the opening lines of the poem refer to the tradition of the Old Attic Comedy. Lines 1-2 say: EVPOLIS atque Cratinus Aristophanesque poetae/ atque alii quorum comoedia prisca virorum est (Eupolis and Cratinus and Aristophanes, true poets and the other men of principle of Old Comedy). Freudenburg (1993, 27-51) stressed the link between comedy and satire, which I addressed before in my discussion of $S .1 .3$, where I mentioned that Horace postures himself as a gentleman commentator with the qualities of a jester. I stated there that in examining the fourth sermo I would further consider Horace's theory on critical political poetry, which is not necessarily satire. Freudenburg (1993, 52-108) discusses satiric poetry and its relationship with contemporary literary theory at the end of the Republican era, specifically the influence of Aristotelian theory (liberal jest) and Hellenistic theory resting on Old Comedy, New Comedy and Callimachus' Iambs. Freudenburg's (1993, 107) final conclusion is that Horace mixes several traditions. ${ }^{127}$ When I discussed S.1.3, I considered the influence of the theory of the liberal jest; in this section I will briefly go through the other traditions which may have exerted an influence on the poet.

Concerning Old Comedy, the opening of S.1.4 with its references to Old Comedy and (according to Quintilian Inst.10.1.65-66) to its chief authors Aristophanes, Eupolis and Cratinus should not be seen as an example of Horace's ironic ineptitude. According to Freudenburg $(1993,98)$, it speaks directly for the [Hellenistic] tradition "of the later practitioners of the iambic idea." Horace reminds us that the poets of Old Comedy admonished wrong-doers openly and we will see below that he expressed explicitly in S.1.4.6-7 that Lucilius wrote in the same tradition. Freudenburg $(1993,99)$

126 For S.1.4, see Ferriss-Hill (2015, 3-17; 103-104; 143-146); Freudenburg (1993, 33-39; 86-100; 119-128; 145-150; 156-162); Gowers (2012, 147-182); Leach (1971); Lefèvre (1993, 104-109); Schlegel (2000; 2010, 253-259).

127 For Horace and the tradition of Rome's first "satirists" Ennius and Lucilius, see Muecke (2005, 33-47). For Horace and the Old Comic tradition, see Cornford (1968); Ferriss-Hill (2015, 1-44; 195-203); Freudenburg (1993, 3-51); Gowers (2012, 148-149; 152-155; 316-318). For a detailed analysis of the Aristotelian theory and the iambographic tradition, and the position of Horace in S.1.4, see Freudenburg (1993, 52-108). See also Dickie (1981). 
quotes with approval Dickie’s (1981, 185-186) final assessment of Horace’s view of Old Comedy as "derived from Hellenistic literary theorizing, that makes Eupolis, Cratinus and Aristophanes the canonical poets of a genre whose defining characteristic was that of holding sinners up to opprobrium (reproach) and that it is in that literary and moral tradition that he [Horace] places himself." Further, the views of Ferriss-Hill (2015) are relevant. Examining Horace's place within the comic tradition, she (2015, 17-19; 217228) also stresses that one of the fundamental characteristics of Attic Comedy to be found again in Roman Satire are the komodoumenoi - people who can be mocked and pilloried. ${ }^{128}$ Contrary to Freudenburg, Dickie, and Ferriss-Hill, I do not interpret Horace's reference to Old Comedy in the opening lines of S.1.4 as placing himself in "that literary and moral tradition," if that place means mocking and pillorying individuals and "holding sinners up to reproach." Firstly, when Horace wrote S.1.4, he had not yet written any censure poetry in what has come down to us as S.1.1-1.3, and I intend to show that neither any satiric poetry bearing his name was going to appear in the rest of S.1. Secondly, although Horace accepted that the genre of satire should hold wrong-doers freely and openly to reproach, I do not find that Horace follows the tradition of the Old Comedy and Lucilius: he never addresses in S.1 wrongdoers directly, either in a mild or an agonistic Lucilian fashion. ${ }^{129}$ Horace had a very different reason for quoting the poets of Old Comedy. He discloses the reason in the next three lines: the reason is the libertas (freedom of speech) with which the poets of Old Comedy wrote. I will explain below that Horace intends to speak and write with equal freedom both in his first book of Sermones - his credentials for Maecenas - and in his poetry in other genres. He sees libertas as an essential quality for good poetry. S.1.4.3-5 says:

si quis erat dignus describi quod malus ac fur, quod moechus foret aut sicarius aut alioqui famosus, multa cum libertate notabant.

(if there was anyone deserving to be described as a ruffian and a thief, as an adulterer or murderer, or as otherwise notorious, they censured him with great freedom of speech)

Scholars argue that Horace in S.1.4.3-5 singled out criminals as being severely censured by the poets of Old Comedy. For example, Gowers (2012, 153) states: "H.[orace] attributes republican-style powers of moral censorship to the Old Comedians, somewhat inaccurately, as they tended to pillory individuals - politicians and sophists, for example - rather than criminals." Horace brought up the poets of

128 The other two characteristics which Ferriss-Hill discusses are the parabasis - the stepping forward of the chorus in Attic Comedy with the direct address of the listeners for conveying a message of the poet - , and the agonistic style. The italics in the quote of Freudenburg are mine. For parabasis, see also Dover (1972, 49-53).

129 For the significance of Old Comedy, see also my discussion of S.1.10. 
Old Comedy for the reason that Gowers suggests. I share her doubt whether lines 3-5 should be interpreted as Horace denouncing ordinary ruffians, thieves and murderers. These lines following immediately those referring to Old Comedy are meant to direct us to the same sort of people as censured by Aristophanes, Eupolis and Cratinus: the lines are a functional reference to individual politicians. In Horace's view, the behaviour of some members of the aristocracy, of many individuals of the political and social elite and the new rich does not contrast with that of criminals. The context of S.1.1-1.3 also points to this conclusion. We saw that in S.1.1 Horace is concerned not only about the loss of moral standards by both the common people and the elite, and the impact on the political stability in Rome and Italy, but also about the social destruction caused by the civil war and its aftermath. The main theme of S.1.2 is the poet's criticism of the immoderate behaviour in sexual relationships and the vulgar conduct and materialistic attitude of the elite and parvenus alike, and the threat of their lack of restraint pursuing their own interests. In S.1.3, he refers to Hermogenes, who exemplifies adaptability and unreliability, and Alfenus, who shows untrustworthiness and dishonesty symbolizing the many who try to force themselves into holding high office and are not deserving such. He continues this line of thought in the opening lines of S.1.4, when he mentions in S.1.4.3-5 "anyone deserving to be described as a ruffian and a thief, as an adulterer or murderer." Horace was not thinking of ordinary criminals, but of individuals in high office murdering opponents, appropriating property, and carrying out other criminal action. It was the time of the expropriations and confiscations when the most fertile land was given to the veterans and the resulting loss of continuity contributed greatly to the famines in Italy during the thirties B.C. Added to this, groups of desperadoes roamed the countryside, and smallholders were particularly exposed to land-grabbing. Last but not least, there were structural changes in the agricultural sector, where the farming estates, the latifundia, were established at the cost of the traditional farmers with the help of capital of the nouveau riche and old elite. Horace did not censure those corrupt politicians as a satirist, but intended to demonstrate to Maecenas that his political opinions were correct. He used in S.1 the instrument of the sermo to present in a civilized manner the reprehensible actions and ideas of several groups of wrongdoers in order to discover in discussion with Maecenas and his circle of friends the common political ground.

The poet makes a second noteworthy point in line 5 . Horace says that the poets of Old Comedy censured criminals with great libertas, freedom of speech. When he wrote this in the 40s and 30s B.C., the issue of libertas was hotly contested. The concept of $\pi \alpha \rho \rho \eta \sigma i \alpha$ (later libertas in Rome) originated in the political sphere of classical Athens expressing the right of freedom of speech for those who enjoyed full civic status. Later in Hellenistic times, parrhesia was not considered any longer a political right, but rather a private virtue, where rank and station became important and the term shifted from freedom of speech to personal candor. According to Konstan et al. $(2007,4)$ 
The shift in the meaning is coordinate with the change from the egalitarian city-state to a regime of powerful rulers in a position to dispense patronage. With these changes, the figure of the flatterer became a key subject of ideological attention.

This shift is very relevant for understanding Horace's inference that the poets of Old Comedy censured with great freedom of speech (multa cum libertate notabant). Several different levels come together in those few words. ${ }^{130}$

Firstly, within the political context, Horace entered a political battleground. He wrote those words at a time of great political changes in Rome, with the risk that the ruling classes discontinued the right of free speech. These changes were similar to those that had occurred in the Greek world with the rise of the Hellenistic kingdoms, and which was at the roots of the shift in meaning of the notion of parrhesia in the Hellenistic world. I refer here to the change in Rome from Republic to Principate with on the one hand its attempts to curtail free speech and on the other hand the arrogation of it by both Octavian and his party and the Pompeians. According to DuQuesnay (1984, 29-32), it may be assumed that Lucilius was used by the Republicans, who had adopted the position of being the defenders of free speech together with the hardline Stoics and the Pompeians who promoted him as their man. The Pompeians set great store by the fact that Lucilius was a great-uncle to Pompey the Great. Lucilius was fostered as the defender of Republican libertas. Thus, Horace, the associate of Maecenas and Octavian, and a follower of Philodemus and the Epicurean school, touches with a discussion of freedom of speech upon a very sensitive political issue. If Horace's words about freedom were perceived as an attack on the traditional republican value, coming from someone near Octavian, this could well be taken as a further example of Octavian's attempts to establish a form of kingship by Republicanminded adversaries, of whom many were members of the Senate and other prominent political bodies. I concur with Anderson's (1982, 16) description of Horace's understanding of libertas as "ideally, the basis of freedom is a sense of responsibility, self-discipline which prevents one from interfering with the liberty of others.”

130 Horace writes about friendship in Ep.1.18.1-9; see also my discussion of S.1.4.81-85. For Horace and libertas, see Anderson (1982, 15-17; 27-28); DuQuesnay (1984, 29-32); Freudenburg (1993, 79): "by Horace's day, the Cynics, iambic poets, and the writers of Old Comedy had been reduced to a single class, noted for their shared commitment to $\pi \alpha \rho \rho \eta \sigma i \alpha$, Latin libertas, the free citizen's right to open abuse without fear of reprisal.” See also Freudenburg (1993, 86-92; 96-97; 2001, 15-23); Konstan et al. (2007) gives the texts of Philodemus "On Frank Criticism," and a detailed exposition on parrhesia. Gowers $(2012,150)$ summarizes the political environment in which Horace finds himself as follows: "H.[orace] also enters a still-vigorous Hellenistic debate about the proper limits of humour: Aristotelian supporters of the so-called 'liberal jest', gentle or gentlemanly laughter, versus Cynics or iambographers who justified frank and aggressive abuse as a moral duty. This debate had acquired a topical edge in the late republic, when libertas was brandished as a slogan by both factions in the civil war, but was increasingly difficult to uphold in a climate of tight state control." See also Gowers (2012, 149; 154-155). 
Secondly, at a personal level, Horace, adhering to the Epicurean view, wanted to distance himself from Lucilius. We will see in the discussion of S.1.4.6-13, and later in that of S.1.10, that Horace judges the work of Lucilius positively with respect to its critical spirit, but rejects the invective manner of Lucilius; he prefers a more restrained way of expressing himself. He recorded in S.1.4.5 with approval that the poets of Old Comedy censured with great freedom of speech, and thus Horace stood up to Lucilius and the Stoics in an indirect manner. He claimed that he, like his associates, was also fully committed to support parrhesia.

DuQuesnay (1984, 30-32) makes an intriguing point suggesting that, although Horace distanced himself from Lucilian invective, it is feasible that he followed the same Lucilius as a model upholding the values of libertas (see also the discussion of S.1.10.67-71). Lucilius was a member of the circle around Scipio Africanus, who was among other things an important patron of the arts. DuQuesnay argues that Horace's claim to be the successor of Lucilius as the new defender of libertas prompts the reader to conclude that Maecenas' circle was the successor to the highly regarded Scipionic circle of the past. I add a further point to DuQuesnay's conclusion, that is that Horace means to say that not only the two circles match, but also that Maecenas therefore is the new Scipio.

Libertas reappears in lines 103 and 132, where Horace uses the word liber in passages concerning freedom of speech. ${ }^{131} \mathrm{I}$ intend to demonstrate later in the discussion of S.1.4 that Horace recognizes two sources of inspiration for his moral guidance in matters of censuring: the first one is the notion of parrhesia and the second one the traditional Roman moral values as handed down by previous generations: mos maiorum, a token of Latin ethnicity. ${ }^{132}$ In his opinion, parrhesia is relevant both in the public and in the private domain. The public domain is obviously the one discussed above in connection with S.1.4.1-5, the censuring of public officials. When I discuss S.1.4.103-105 and S.1.4.132-133, we will see that Horace reflects on frank criticism among friends; he follows the teaching by Philodemus in his treatise

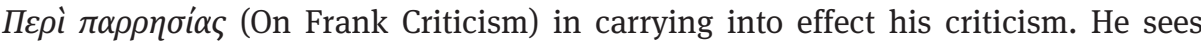
mos maiorum as his moral guide of conduct among friends. The two go together. He touched already briefly upon his inspiration for moral guidance, mos maiorum, in S.1.1.15-22, and we will see that the inspiration by mos maiorum returns in S.1.4.81-85, S.1.4.93-103 and S.1.4.115-119.

Next, in lines 6-21, Horace considers the work of Lucilius in more detail. He places Lucilius squarely in the tradition of Old Attic Comedy. Firstly, in lines 6-7 he writes: hinc omnis pendet Lucilius, hosce secutus/ mutatis tantum pedibus numerisque (Lucilius wholly depends on them, and them he followed changing only metre and

131 Liber in S.1.4.89 refers to Bacchus, and liber in S.1.4.90 to a dinner guest who talks too freely when drunk.

132 Conform DuQuesnay (1984, 32). 
rhythm). In lines 7-13, he gives his detailed commentary on Lucilius' work, who wrote some thirty books of satires. Horace will return to S.1.4.7-13 in the opening lines of the tenth sermo, and in S.1.10.56-71 (see section 2.2.5) he will tone down some of his criticism of Lucilius. S.1.4.7-13 reads:

emunctae naris, durus componere versus:

nam fuit hoc vitiosus: in hora saepe ducentos,

ut magnum, versus dictabat stans pede in uno:

cum flueret lutulentus, erat quod tollere velles:

garrulus atque piger scribendi ferre laborem,

scribendi recte: nam ut multum, nil moror.

(Lucilius was witty, keen, but rugged in the composition of verses: in fact in this [ruggedness] he was faulty: in an hour he would often dictate two hundred lines standing on his head [lit. standing on one foot = with great ease], as though it were a big deal: when he flowed in his muddy stream, there was much you would like to remove: he was garrulous, and too lazy for the toil of writing - I mean of writing properly. For I am not interested in quantity)

In S.1.4.7-8, Horace judges the work of Lucilius positively, whom he describes as witty, keen and rugged in the composition of verses, "implying that in his rugged word arrangement, just as in his clever, stinging wit, Lucilius consciously imitated the Attic masters of Old Comedy mentioned at Satires 1.4.1, showing all the traits of a good Atticist" (Freudenburg, 1993, 157). Rudd (2007, 91) states: "another point often overlooked is that 1.4 carries no condemnation of Lucilius' spirit," and that although Horace is positive about the manner in which Lucilius succeeded as a Roman successor to the best of the Old Comedy, he did not write his Sermones after the manner of Lucilius. ${ }^{133}$ According to Freudenburg $(2001,19)$, the latter's satires "were famous not for their ironic undercurrents, but for their searing abuse of Rome's most prominent writers, political figures and men of high social standing, both living and dead."

In the next line 9, Horace uses the word vitiosus (faulty), which is often understood to mean that the poet criticizes Lucilius for his ruggedness. I agree with Rackham, also mentioned by Freudenburg, that the poet did not mean a "straightforward negative assessment” (Freudenburg, 1993, 157) at all. Rackham (1916, 224) remarks about this: "In 1. 9 I take 'hoc' to look backward, not forward: 'In fact in the last of these three characteristics [durus] Lucilius was faulty' - he carried roughness of versification to excess. This is developed in the loosely connected sentences [S.1.4.9-13] that follow: the fault was due to Lucilius's rapid work." ${ }^{34}$ The rejection of refinement in the

133 For Horace and Lucilius in general, see Fiske (1966). For Horace and Lucilius in S.1.4, see also Fiske (1966, 277-306); Hendrickson (1900); Leach (1971, 623-624); Rudd (2007, 86-92). Schegel (2000, 93-107; 2010). See also the discussion of the opening of S.1.10.

134 For Lucilius' style, see Freudenburg (1993, 150-162). For the translation of line 9 I follow Rackham 
rugged style advocated by the Atticists stems from the Stoic views of a "rugged" word order. What did the Atticists' rugged style stand for? According to Freudenburg (1993, 152), the Atticists stood for "a conscious effort to dissolvere orationem, that is to break apart the smooth collocation of words [...]. They wanted their every word to appear 'tossed off' (abiectum), that is, rugged and unstudied." Atticists in particular held anticompositional theories as they rejected artificiality, although their ruggedness was anything but unstudied. ${ }^{135}$ Freudenburg's observations relate to what in essence is not only a matter of literary style, but also a matter of politics. Horace's verdict alludes also to one of the many political confrontations between Republicans and Caesarians. It is feasible that Horace raised these points of style in S.1.4.7-10 not only as part of his argument with Lucilius about satiric style, but also as part of his dispute with the Stoics about their philosophical views. Thus, he continued his rejection of Stoic doctrines such as of those we saw in S.1.3 - that all sins are equal and the Stoic paradox that only the wise man (sapiens) was perfect - by also pouring scorn over their literary views.

Horace's use of the flooded-river analogy is not by chance, as this analogy was often used in the debates on word arrangement; an issue on which he and his critics had such different opinions. ${ }^{136}$ Freudenburg analyses extensively this stylistic element in S.1.4. He $(1993,160)$ refers to "Quintilian's lengthy study of word arrangement in Book 9 of the Institutes which contains numerous references to the river analogy within a technical analysis of arrangement, and thus it serves to demonstrate the untold variety and serviceability of the metaphor in ancient compositional theory." Freudenburg concludes that Horace's criticism of Lucilius in lines S.1.4.6-13 fits the criticism coming from ancient compositional theory, and he $(1993,162)$ interprets the river analogy as that "much as a learned allusion to Callimachus, it is a well-worn, even trite illustration of ancient compositional theory, designed to make a technical point about the way in which Lucilius set his words side by side.” Horace also makes a different point criticizing in S.1.4.11-12 a second stylistic imperfection of Lucilius. The combination of cum flueret lutulentus (when he flowed in his muddy stream) in line 11 and garrulus (he was garrulous) in line 12 implies that in Horace's view Lucilius lacks terseness (brevitas). Lucilius cannot write sharply worded thoughts. Horace will return to this point in S.1.10.9-10 when he reviews S.1.4 and gives his view on standards of good poetry, of which brevitas is one: est brevitate opus, ut currat

(1916, 224). In line 10, I follow the suggestions of Gowers $(2012,136)$ for "ut magnum" and for "stans pede in uno."

135 Conform Freudenburg (1993, 150): “anticompositional theories, [...], gained increasing support in the early 40s B.C., especially among the Stoics, who somehow identified a rugged, natural style of arrangement, such as that which they knew from Lucilius, with Stoic virtue and the bygone values of the old Republic."

136 For a summary of the use of the swollen-river analogy by Horace, see Freudenburg (1993, 158 note 86). 
sententia neu se/ impediat verbis lassas onerantibus auris (one needs brevity, in order for the train of thought to run on, and not to get entangled with words that overwhelm exhausted ears).

Horace's criticism of Lucilius in S.1.4.1-13 concerns Lucilius' skill (ars), and is not about the content (res) of the latter's satires (see also the discussion of S.1.4.38-62). Schlegel $(2010,258)$ draws the same conclusion when she relates her discussion of the opening of the fourth satire (lines 1-26) to the passage at the end of the poem where "Horace's father" gives his moral teaching to "his son" (S.1.4.105-143). ${ }^{137}$ She writes: "Just as notabant (5) is redeployed in Horace Sr.'s notando [(106)], other words too from the beginning of the poem are borrowed to do new work at the end of the poem. Lucilius was poetically vitiosus [(9)], but it is examples of ethical failings (vitiorum, 106) that Horace's father now [S.1.4.105-143] marks." I will consider "Horace's father's" supposed advice with respect to these ethical failings in more detail below when I discuss the final passage of the poem, that from line $103 .{ }^{138} \mathrm{I}$ will argue that his aim is to demonstrate that his opinions accord with the traditions of the old Roman values.

Horace asserts in lines 5-7 with approval that Lucilius wholly stood in the tradition of the poets of the Old Comedy (hinc omnis pendet Lucilius, hosce secutus), who freely chose their targets and censured with great freedom of speech (multa cum libertate notabant). Horace will preserve his right to do the same and express himself freely, but in a very different style than that of Lucilius. In addition, he will adjust his style to his audiences. According to Freudenburg (2005b, 7): "Horace projects a far different sense of himself in his 'Conversations' than Lucilius did in his searingly nasty satires. He speaks in softer, more cautious tones, telling us that he means well by his criticisms, that he intends only to tell the truth, and that no one need take offense." ${ }^{139}$ Horace says indeed in these lines, that he doesn't wish to imitate Lucilius, but he did not say either that he wants to be a satiric poet, not even one with a milder style. He says that Lucilius wrote in an invective style, but that such a style doesn't fit the purpose for which Horace writes his poetry.

In the second half of this passage, S.1.4.13-21, Horace gives a cheerful sketch ridiculing the verbosity of some authors. He depicts a challenge by Crispinus, presumably the same long-winded Stoic babbler we met in S.1.1.120 and S.1.3.139, to see who can write most ('videamus uter plus scribere possit') (S.1.4.16), a contest of who can write with the greatest speed and thus recalling Lucilius' achievements of lines 9-10. ${ }^{140}$ I interpret Horace's tongue-in-cheek words of S.1.4.17-18 di bene fecerunt

137 Schlegel (2000) also observes in her paper several times that Horace criticized Lucilius on style. Examples are: (2000, 94) "distinguishing himself from Lucilius stylistically"; (2000, 102) "Lucilius, lazy with words, is ultimately no model for Horace"; $(2000,106)$ "In Satire 1.4 Horace creates a distance between himself and Lucilius, his literary father."

138 Italics in the quote of Schlegel are mine.

139 For the comparison between Horace and Lucilius, see also Gowers (2005, 54-55).

140 For Crispinus, see also note 75. 
inopis me quodque pusilli/ finxerunt animi, raro et perpauca loquentis (the gods be praised for creating me with a weak intellect and petty spirit, one that speaks rarely and scantily), that he intends to write with restraint and in simple language, thus "depreciating his talents in language that Crispinus would approve" (Oliensis, 1998, 22). In addition, that he will not write hastily, but in a polished and attractive style in which he considers his words carefully. Nothing certain is known of Fannius in S.1.4.2122, of whom several scholars conjecture that he was a follower of Sextus Pompey. He was obviously an author of sorts, who perhaps either presented his works to private libraries or tried to market them through book dealers. ${ }^{141}$ This is not Horace's way of doing things. He pretends that no one reads his writings (mea nemo/ scripta legat), and that he is afraid of reciting them in public, because some if not most do not like critical censure poetry, as they themselves ought to be censured. Horace states that there is not much benefit in writing such poetry for a large audience, as the crowd would not pay attention and thus would not get the message anyway. Further, his credentials, his Sermones, were aimed particularly at a select and small group of people. At other places Horace has testified which kind of audiences he preferred. ${ }^{142}$ For example, Horace writes later in this poem, in S.1.4.71-74: I want no bookshop to have my little books or column to advertise them, [...]. I do not recite to anybody save friends, unless I am forced, not anywhere or before whoever it may be (nulla taberna meos habeat neque pila libellos,/[...] nec recito cuiquam nisi amicis, idque coactus,/ non ubivis coramve quibuslibet). Further, in S.1.10.73-74, which he probably wrote in the year 35 B.C., he also says that he does not attempt to reach large audiences: neque te ut miretur turba labores,/ contentus paucis lectoribus (and that you should not strive to get the admiration of the crowd, but that you be content with the select few as your readers). Horace made the same point in S.1.10.39; nec redeant iterum atque iterum spectanda theatris (these [his poems] should not come back again and again to be seen in the theatres). About twenty five years later he still held the same

141 For Fannius, see DuQuesnay (1984, 56): "if the Fannius of 1.10 .80 is related to or even identical with C. Fannius, the adherent of Sextus;” Freudenburg $(1993,117)$ conjectures that Fannius of S.1.10.80 is the same man as the one in S.1.4.21: "In this [S.1.4.21] he [Horace] associates Fannius with Crispinus, suggesting that he [Fannius] too wrote in verse, perhaps on the themes of Stoic ethics. We know from Satires 1.10.80 that Fannius was, by reputation, a constant dinner companion [...] of Hermogenes." The context of S.1.10.80 supports Freudenburg's view that Fannius was an author. See also Rudd (2007, 101; 119-120; 132). Syme (2002, 228; 333-334) suggests a different option for the identity of Fannius. He could be one of the historical Fannii. One of them was a follower of Sextus Pompey, the other was of the anti-Caesarian party. For Fannius, see also the discussion of S.1.10.78-80. For the marketing of books in general, see Weeda (2015, 38-39). For Fannius and his desire to have his work published, see Rudd (1956).

142 See my discussion of Horace's preference of audiences in section 2.1 w.r.t. his inspiration by Archilochus et al. and the role of iambus in archaic Greece that was written for the symposium, an audience of philoi. See also Weeda (2015, 41-42). 
opinion. ${ }^{143}$ In 12 or 11 B.C. he wrote a lengthy passage about three forms of poetry in his Epistula ad Augustum (Ep.2.1.156-218), in which he (2.1.214) asks Augustus to look favourably on his art, which is poetry for private reading (lectori credere; to entrust themselves to a reader). In his earlier Ep.1.19, written between 23 and 19 B.C., Horace expressed similar feelings. In the lines 41-44 he says: 'spissis indigna theatris/scripta pudet recitare [...]'/ si dixi, 'rides,' ait, 'et Iovis auribus ista/ servas' (If I said, "I feel ashamed to recite my unworthy work in your crowded theatres," says he "you are merry, and preserve your work for the ears of Jove [Augustus]"). In his Ars Poetica written either between 22-18 B.C. or towards the end of his life - Horace poured scorn again on the writing for large audiences and showed himself dismissive of the taste of large crowds either in the theatre or in someone's townhouse. In Ars.212-213 he wrote: indoctus quid enim saperet liberque laborum/ rusticus urbano confusus, turpis honesto? (What taste indeed would the man, ignorant and just finished with his hard work, have, a peasant mixed up with a man from town, the man without breeding with the respectable?). Lowrie (2009a, 11) takes a similar line when she argues on the ground of the opening line of the first Roman Ode: "When Horace sets a premium on poetry's aesthetic quality, he makes a similar gesture against entertainment in favour of a higher standard that separates him from popular culture ('odi profanum uulgus' (I despise the vulgar throng), Odes 3.1.1)."

As a result of the political situation in the 30s B.C. and after the composition of the Senate changed considerably and the traditional political rhetoric disappeared gradually. Rhetoricians had developed the practice of declamation and when the opportunity for political oratory dried up, declamation became a successful form of entertainment. The result was that the public that attended poetry grew fast. Poets followed the example of rhetoricians and sought large live audiences. Seneca (Maior) in his Controversiae (Con.4.2) testifies that Pollio in the 30s or 20s "became "the first of the Romans to recite his works to an invited general audience”" (White, 1993, 59-63, esp. at 60; 2005, 322-323). The passages from Horace's poems tell us firstly, that largescale recitations (spissis theatris) of poetry took place and that Horace detested these. Secondly, that he did not have much regard for the typical theatre crowds and did not want to cater for their tastes (Ep.1.19 and 2.1). Thirdly, that he was a lucky fellow as he could read his poetry to auribus Iovis, Augustus' ears.

Although I mentioned at the opening of my discussion of S.1.4 that I will focus in my examination of lines 1- 62 primarily on Horace's style, being an important topic of what is something approaching the first half of the poem, I cannot avoid considering occasionally his ideas with respect to the other two fields of his intended authorship,

143 Quinn (1982, 146, note 232) argues that Horace may have used the words contentus paucis lectoribus in S.1.10.74 as an argument answering public criticism of his fourth Sermo and that the words do not represent his preferred kind of audience. This is unlikely, as Horace repeats his preference several times during a period of 25 years or more. For the dating of Ars Poetica, see Nisbet (2007, 20). 
that is the subject matter, and the targets of his sermones. I will consider those in more detail when I discuss lines 105-115. Horace continues to follow in the fourth sermo the path of the previous three sermones, that is defining the different groups of individuals who ought to be critically judged. In S.1.4.22-27, he introduces yet another class of wrong-doers who are to be considered:

cum mea nemo

scripta legat vulgo recitare timentis ob hanc rem, quod sunt quos genus hoc minime iuvat, utpote pluris culpari dignos. quemvis media elige turba: aut ob avaritiam aut misera ambitione laborat: hic nuptarum insanit amoribus, hic puerorum; (while nobody reads my writings, I fear reciting them in public, because this genre [censure poetry] pleases least, since most people deserve censure. Choose anyone from a crowd: either he suffers from avarice, or from a miserable ambition; one is madly in love with married women, the other with boys)

In this passage, Horace not only introduces a different class of people, but also a new form of criticism; it is the censure of social control and street gossip. Freudenburg $(1993,100)$ points out that in those lines Horace not only makes a significant shift in the sections of society to which he pays attention, but also that he introduces traits of "Cynic diatribe, where, from the street corner or market stall, the [Cynic] moralizer harangues and lampoons those given over to avarice, ambition, greed, and lust, which are hardly equivalent to murder, theft, and adultery.” Hunter (1985, 486-487) adds to this that Horace also brings in characteristics of New Comedy: "the verses [S.1.4.3-5 and S.1.4. 26-31] take us into the world of New Comedy and of Horace's own satires, without actually abandoning Old Comedy entirely." 144 He describes in lines 22-27 the behaviour of common people that appears to be the same as that which he saw in the upper layers of society in S.1.1 and S.1.2. For example, he depicted in S.1.1 the avaritia, ambitio and luxuria, and the social and political risk of unrestrained greed and ambition of the elite. In S.1.2 he continued this approach blaming the unabashed behaviour by members of the Roman aristocracy, which he saw as typical for the degeneration of standards within the elite caused by the growing influence of the urban nouveau riche with their materialistic attitude, their hunting for status, and lack of restraint. In S.1.4, he extends the class of people deserving censure from the elite to Roman society in general (turba): in S.1.4.24-25 he is very specific about this when he says utpote pluris/ culpari dignos (since most people deserve censure). Hunter and Freudenburg interpret this as the poet's shift in his view, that is the recognition that

144 For S.1.4 and New Comedy, see also Gowers (2012, 159-162). Freudenburg and other scholars generally call Horace "satirist," and use the term "satire” for his poetry in Sermones 1. For the sake of clearness, I recall that I chose the term sermo, in accordance with what I regard the poet's intention. 
not only the severe public invective against the political elite and against criminal behaviour, but also the "softer" censure of the relatively minor misdemeanours of the people at large are part of censure poetry. The latter was a result of the practices of New Comedy. Freudenburg $(1993,100)$ summarizes this as follows: "This last point [by Hunter (1985, 487), namely taking us into the world of New Comedy, without actually abandoning Old Comedy entirely] is extremely important, for it suggests that Horace, as a theorist and practitioner of satire, does not simply dismiss one tradition in favor of another." Freudenburg and Hunter interpret this passage in the literary frame, while I read Horace's reference to the people at large in the functional frame. His approach in the above passage S.1.4.22-27 is similar to that in lines S.1.4.3-5. He continues his search for the behaviour of people deserving censure, because he seeks to convince Maecenas that he recognizes the social evil with which he does not want to be associated in all classes of society. Thus, I see the reference as his intimation to Maecenas that he does not exclude any section of Roman society from his scrutiny.

After criticizing people's obsession with silver and bronze in line 28 hunc capit argenti splendor; stupet Albius aere (one is obsessed by the splendour of silver; Albius is stunned by bronze), Horace returns to the first sermo of the book in the following lines, censuring the avarice of traders. ${ }^{145}$ S.1.4.29-30 reads: hic mutat merces surgente a sole ad eum quo/vespertina tepet regio (another sells his goods from where the sun rises to where the western region is warmed [by the sun]). The trader works day and night, because he fears that his wealth will not grow (metuens aut ampliet ut rem) (line 32).

The lines that follow touch on the subject of defensive poetics. ${ }^{146}$ S.1.4.33-35 reads:

omnes hi metuunt versus, odere poetas.

'faenum habet in cornu; longe fuge: dummodo risum

excutiat, sibi non, non cuiquam parcet amico'

(Those people fear verses and hate poets. "He has hay on his horns. Don't go near him! As long as he can extract a laugh, he will not spare himself or any friend”).

145 The unknown Albius returns as faring poorly (male vivat) in line 109.

146 For S.1.4.35 there are two readings in the original manuscripts: either excutiat sibi, non hic cuiquam or excutiat, sibi non, non cuiquam. I choose the latter option conform OCT (Wickham, 1957) and Gowers (2012,161): "with sibi (MSS), the sense and even phrasing have a close precedent in Arist.

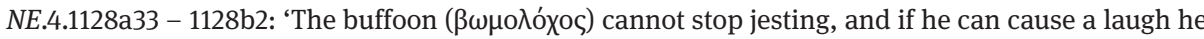
doesn't spare himself or anyone else. And he says the sort of things the polite gentleman never says,

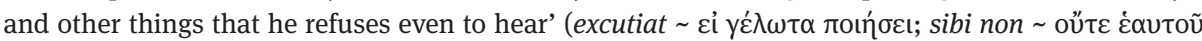

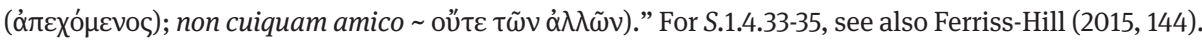
Gowers does not interpret lines 33-35 as defensive poetics. 
Dangerous animals, like mad bulls, were given hay on their horns to mark them out in the field. The satirist is like a mad bull. Scholars have remarked that satirical poets are often loathed by their targets, and that is what caused the satirists to write defensive poetry. ${ }^{147}$ For example, Ferriss-Hill referring, among other poems, to S.1.4 concludes that Horace took up defensive poetics already in $S .1 .4$ because he felt wronged by real or imagined criticism of his poetry. S.1.4 has indeed several references to people who are not pleased by the satiric genre. The first one is S.1.4.22-27 (see above), when he says in lines 24-25 quod sunt quos genus hoc minime iuvat, utpote pluris/ culpari dignos (because this genre [censure poetry] pleases least, since most people deserve censure). Then follows line 33, and later in the sermo S.1.4.91-93, what is seen as a form of defensive poetry when he says lividus et mordax videor tibi? (do you find me malicious and snarling?) (see below). Ferriss-Hill (2015, 144-156) gives more examples in S.1.10, S.2 and the Epistulae. However, I propose the following counterarguments against her interpretation. My arguments stem from the contexts, not only that of Horace's objective of writing S.1 - his credentials for Maecenas - but also the context of the quoted passages within S.1.4. Concerning his objective for the book as a whole, I argue that Horace's reflections on the style and content are not the result of his search for his poetic orientation, but are part of his discussion about his political orientation with Maecenas and his circle. His pronouncements about the satiric genre are markers for his political and social views intended to convince Maecenas that he holds the right political opinions and that he has the right social background. In addition, he writes those for discussion within a limited circle. Looking at the passages in S.1.4, which are interpreted as supporting the view that Horace writes defensive poetry, I argue that the context of the poem does not lead to this conclusion. The context of lines 22-27 is the discussion with Maecenas about the moral standards of common people. The words in lines 24-25 "because this genre [censure poetry] pleases least, since most people deserve censure" (quod sunt quos genus hoc minime iuvat, utpote pluris/ culpari dignos) mean that common people would not like to hear what Horace thinks of those standards, but that he does not intend to make his views known publicly. Equally, the words in lines 33-35 "those people fear verses and hate poets" (omnes hi metuunt versus, odere poetas) and a poet "will not spare himself or any friend, as long as he can extract a laugh" (dummodo risum/ excutiat, sibi non, non cuiquam parcet amico) are a general statement about common people’s perceptions

147 For the writing of defensive poetry, see Feeney (2009b, 20); Ferriss-Hill (2015, 121-143); Freudenburg (1993, 119-150); Gowers (2012, 162-163); For Horace and defensive poetry, see Ferriss-Hill (2015, 143-156). For S.1.4 and defensive poetry, see Oberhelman \& Armstrong (1995, 237), who refer to a.o. Freudenburg (1993, 52-53); Kiessling (1959, xxi); Wili (1965, 71; 71 note 2); Rudd (1955a; 1955b; 2007, 88-89). Hendrickson $(1900,124)$ was the first to suggest that Horace did not write defensive poetics in S.1.4: "I do not believe that Horace is here justifying himself before the harsh criticisms of a public which felt aggrieved and injured by his attacks, nor do I believe that the contents of the satire and the criticisms of himself which it presents are drawn from life." 
of poetry. I consider S.1.4.24-25 and S.1.4.33-35 statements of facts in a discussion, not defensive poetry. We will see below in my discussion of S.1.4.91-93 that lines 91-93 are also statements of fact in a discussion, similar to lines 24-25 and 33-35. He puts in S.1.4.91-93 a rhetorical question within the context of a discussion about acceptable censure of the urban nouveau riche with their materialistic attitude, their hunting for status, and lack of restraint. His answer to the rhetorical question "do you find me malicious and snarling?" (lividus et mordax videor tibi?) is that he writes openly without malice. This is not a defensive reaction against criticism from people who felt wronged by him, as he had not written anything addressing them.

Next, Horace gives in reply to his critics in a long passage (S.1.4.38-62) his views on the writing of poetry considering the unity of natural talent (ingenium), and therefore skill (or the lack) of composition (ars), content (res), and style (verba). Horace also deals with matters of content (res) in the remainder of S.1.4. ${ }^{148}$ The first eleven lines (S.1.4.38-48) of this important passage read:

agedum, pauca accipe contra.

primum ego me illorum dederim quibus esse poetas

excerpam numero: neque enim concludere versum

dixeris esse satis; neque si qui scribat uti nos

sermoni propiora, putes hunc esse poetam.

ingenium cui sit, cui mens divinior atque os

magna sonaturum, des nominis huius honorem.

idcirco quidam comoedia necne poema

esset quaesivere, quod acer spiritus ac vis

nec verbis nec rebus inest, nisi quod pede certo

differt sermoni, sermo merus.

(come now, listen to a few words to the contrary. First, I might strike out myself from the number of those I would grant to be poets, for you might not say it is enough to round off a metrical line, and if one writes more like conversational prose, as I do, you might not hold him to be a poet. Someone with natural talent, or an almost divine intelligence and a grand voice, you might give that man the honour of that name [poet]. For that reason some have asked whether comedy would or would not be poetry, because [in their opinion] it lacks an ardent spirit and energy both in style and content, and except for the fact that it differs from conversational prose in having a rigid metre, it is pure prose)

In lines 39-42, Horace makes twice a statement in which he seems to strike himself out as a poet: concludere versum, that is being able to write metrically, or writing poetry like prose (sermoni propiora) is not enough to qualify. These lines, however, are not

148 See also my discussion of S.1.4.38-62 in section 2.1. For a comprehensive analysis of the poetic structure of this passage in which the ideas of metathesis, ars/ingenium and res/verba are discussed and also the poetic skill of Horace, see Oberhelman \& Armstrong (1995). See also Freudenburg (1993, 150); Gowers (2012, 163). Marouzeau (1936) discusses word arrangement in Horace's poetry in general. He does not mention S.1.4. 
meant as a qualification of his own poetry, but as an introduction to the passage as a whole and should be read as: "I could not be considered a poet, if I were not to meet the following standards." Hence, Horace recapitulates in lines 43-44 two of the requirements for true poetry, that is that somebody who lacks ingenium and ars cannot be a true poet. Next, in lines $45-48$ he continues by extending the required qualities of poetry with those of content (res) and style (verba). ${ }^{149} \mathrm{He}$ does this in his answer to those who question whether comedy should be considered poetry. Horace gave his answer that comedy is poetry already in the opening lines of the poem where he says that Eupolis, Cratinus and Aristophanes are true poets (Evpolis atque Cratinus Aristophanesque poetae). Here, he specifies his previous answer by saying that poetry also needs spirit and energy in style and content and in the comic scene of the angry father in lines 48-52 he demonstrates that good comedy possesses both spirit and energy. Horace gives a gripping description of the father (pater ardens), fuming because his playboy son (nepos filius) madly in love with a courtesan girlfriend (meretrice insanus amica) spends his money on her and drink (ebrius) while he could marry a woman with a large dowry (uxorem grandi cum dote recuset). ${ }^{150}$ Spirit and energy, passion galore making this short piece of comedy good poetry.

In addition, Horace adds in S.1.4.53-62 a fifth requirement for good poetry: wordorder. The mastery with which he presents the word-order shows him to possess both ingenium and ars in abundance to make him a true poet. Horace demonstrates in this passage that the simple language of comedy and sermo can also make true poetry, but that words cannot be disarranged without damaging the poem. ${ }^{151}$ In S.1.4.53-56, the opening lines of the passage, he says:

ergo

non satis est puris versum perscribere verbis,

quem si dissolvas, quivis stomachetur eodem

quo personatus pacto pater.

(therefore, it is not enough to write at length in simple language such that, if you rearrange, any father you please could rage in the same way as the father in the play does)

I interpret these lines as: simple language (puris verbis) should be used in the writing of poetry, like that which is used by the personatus (the actor who wears a mask) in comedy: the pater ardens of line 48. In addition word arrangement should

149 Conform Oberhelman \& Armstrong (1995, 249-252).

150 I owe the translations of "playboy" for nepos, and "madly in love with" for insanus to Gowers (2012, 166).

151 For Sermones in the context of Late Republican stylistic theory, see Freudenburg (1993, 109-184). For Horace and word arrangement in S.1.4, see Freudenburg (1993, 132-150); Oberhelman \& Armstrong (1995). For Philodemus and metathesis, see Armstrong (1995). Brown (2007, 131) recognizes that Horace is "not seeking to elevate the style of satire into something more grand." However, Brown does not discuss the issue of word arrangement. 
be natural, so that meaning and structure of a verse match and are in harmony, as he demonstrates with lines 58-59 et quod prius ordine verbum est/ posterius facias, praeponens ultima primis (and you place the word that is earlier later, placing last things before first). Horace maintained at the beginning of lines 58-59 the natural arrangement (prius before posterius), but closed line 59 with ultima (last things) before primis (first), making structure a "mirror image of meaning" (Freudenburg, 1993, 147). Horace quotes at the close of this passage (S.1.4.59-62) a famous line from the Annals of Ennius. ${ }^{152}$ The four lines read:

praeponens ultima primis,

non, ut si solvas 'postquam Discordia taetra

Belli ferratos postis portasque refregit,'

invenias etiam disiecti membra poetae.

(placing last things before first, you would not find the limbs even of a dismembered poet as you would when you take apart "When disgusting Discord had broken up War's iron posts and gates.”)

Horace says that rearranging verses is like murdering the poet. I interpret this as follows: by using metathesis - which he indicates by si dissolvas (if you rearrange) in line 55 and by si solvas (when you take apart) in line 60 - the meaning of Ennius' lines can change. Horace expresses here Philodemus' view (see my citation of Oberhelman and Armstrong, 1995, 244-245, given below). According to Freudenburg (1993, 149), Horace used an Aristotelian metaphor where

metathesis is described as a 'butchering' or 'dismembering' of a living whole. [...] Thus, only superficially do word choice and theme win out over the claims of arrangement, for what, at one level speaks in defense of anticompositional theory, at another level proves its own ineptitude; the claims of arrangement are, in the end, ironically vindicated.

Horace probably knew his Aristotle well enough and "Horace, time and again in his works, proves himself a consummate stylist, trained in the technical refinements of arrangement so important to ancient theory" (Freudenburg, 1993, 149). ${ }^{153}$

Summarizing the first sixty two lines of S.1.4, we note that those exhibit again Horace's faithfulness to the Epicurean maxims for poetry as put into words by Philodemus of Gadara, who had assembled in his Neapolitan circle amongst others Virgil, Plotius Tucca, Varius Rufus and Quintilius Varus, to whom Horace refers as a group in S.1.5 and S.1.10. The Epicurean maxims stem from their conviction that

152 The quote is from ENN.Ann.225-226 (Skutsch).

153 Acc. to Freudenburg $(1993,150)$ "it was, in all likelihood, the Satires that earned Horace a place among the friends of Maecenas, marking him as one of the finest theorists and poets of his day." See also Oliensis $(1998,23)$. 
harmony, balance and unity are essential values. ${ }^{154}$ The maxims are in short the unity of ingenium and ars as mentioned by Horace in lines 43-44, res and verba (the subject of lines 45-48), and the issue of the impossibility of metathesis in good poetry, as expressed in lines 53-62. The relationship of ingenium and ars had been a favourite subject of literary debate for a long time when Horace wrote the Sermones. However, from the doctrine of the Stoic paradox, that is that only the wise man (sapiens) was perfect and thus talented (see my discussion of S.1.3.124-133) followed that the Stoics saw ingenium (natural talent) as the main attribute for writing good poetry. During the first century B.C., this resulted that the Stoics favoured natural talent (ingenium) over skill (ars) contrary to the Epicureans who looked at the matter as a whole and stressed the unity of the two. ${ }^{155}$ Concerning res/verba Oberhelman and Armstrong $(1995,249)$ state that

Res/verba as an organic whole was part of Horace's poetic creed throughout his career. [...] Res/verba, too, is at the root of Horace's attack on Lucilius. In Horace's opinion, res and verba are so linked to the creative and conscious artistic processes of the poet [...] as to render them inseparable from these processes and from each other. Poetry, in other words, is ars and ingenium and res and verba interwoven into a unity.

Horace will return to res/verba in S.1.10. Further, we saw earlier in the discussion of S.1.4.7-13, that the rugged word arrangement favoured by the Stoics was set against the compositional theory to which the Epicureans adhered, amongst them Horace and his associates in Maecenas' circle (see also note 135). Finally, the Epicureans and Stoics held very different views on metathesis. According to Oberhelman and Armstrong (1995, 244-245) .

\begin{abstract}
Horace's views on metathesis are directly related to Philodemus', which were set forth elsewhere [by Armstrong (1995)]. To restate in simple terms, Philodemus objected to the tactic of metathesis because any change in style, any change in expression, results in a change in thought: [...] Metathesis with its rearrangement, therefore, is impossible in the case of good poetry.
\end{abstract}

The Stoics, on the other hand, held, on grounds of their anticompositional sentiments and their dedication to the natural poetic talent, that metathesis with its rearrangement is a powerful and relevant tool. We saw above that Horace demonstrated in lines 53-62 the destruction of good poetry by applying metathesis.

Horace's criticism of the Stoic theories regarding poetry is visible not only through his poetic analyses in S.1.4.1-62, but also through the men he mentions in these lines, and indeed also in the section that follows, S.1.4.63-78. Referring to a number of

154 For the unity of ingenium/ars and res/verba in the Epicurean theory of Philodemus of Gadara and in Lucretius, see Oberhelman \& Armstrong (1995, 249-252).

155 For the Stoic elevation of ingenium over ars, see Freudenburg (1993, 145-147). For the balance of ingenium/ars and res/verba, see Oberhelman \& Armstrong (1995, 240; 247). 
Stoics, Horace focuses Maecenas' attention not only on his technical understanding of poetic theory, but he also places himself clearly within Maecenas' Epicurean camp. In other words, his poetic principles form the literary part of his credentials. Who are those men? The first one is Crispinus of line 14 and we saw earlier that he was a writer on Stoic ethics (see notes 75, 141). Fannius of line 21 was most likely an adherent of Sextus Pompey, who also wrote on the themes of Stoic ethics (see also notes 75, 141). It is likely that Pomponius of line 52 was a victim of prosecutions and sympathizer with Sextus, although he is not positively identified. Further, I will suggest below that the satirists Sulcius and Caprius of lines 65-66 and 70 had Stoic leanings and I note that according to DuQuesnay it is possible indeed that the bandits Caelius and Birrus of line 69 were supporters of Sextus. ${ }^{156}$ Albius of line 28, a man of expensive taste (see S.1.4.109), cannot be identified.

Line 63 contains an explicit message: hactenus haec (enough of this), no more writing about style. In what follows Horace will discuss matters of content, such as the moral objectives of his genre. S.1.4.64-65 reads nunc illud tantum quaeram, meritone tibi sit/ suspectum genus hoc scribendi (now I will ask nothing more than this: does this genre of writing deserve your suspicion?). His poems are not like those of Sulcius and Caprius. Radermacher $(1935,81)$ suggests that the two names taken together

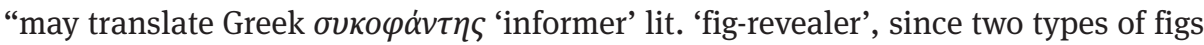
were known as ficus sulca and caprificus." Hence, Sulcius and Caprius should refer to informers. I concur with Rudd (2007, 144 note 31) that "it is ingenious but somewhat far-fetched. [...] on the whole it is probably best to take the names as referring to contemporary lampoonists." 157 Ullman (1917, 117-119), who argues convincingly that Sulcius and Caprius refer to contemporary satirists, discusses the two names within the context of the whole passage S.1.4.65-78, in which Horace brings together several characteristics of how he sees his future work as a political commentator. The libellis in line 66 do not refer to writs, accusations or notebooks of informers, but look forward to the libellos of line 71 . Lines $65-78$ read:

Sulcius acer

ambulat et Caprius, rauci male cumque libellis, magnus uterque timor latronibus; at bene si quis et vivat puris manibus contemnat utrumque. ut sis tu similis Caeli Birrique latronum, non ego sim Capri neque Sulci; cur metuas me? nulla taberna meos habeat neque pila libellos,

156 For Pomponius, see DuQuesnay (1984, 53-54; 54 note 163), "it is natural to link them [a Pomponius and a Balbinus in 1.3.40] with their notorious homonyms [as described by Appian in App. BC.4.45, 50];" Freudenburg (1993, 124); Gowers (2012,166). For Caelius and Birrus, see also DuQuesnay (1984, 54, note 163).

157 Conform Freudenburg (1993, 109; 118). See also Gowers (2012, 169). 
quis manus insudet vulgi Hermogenisque Tigelli.

nec recito cuiquam nisi amicis, idque coactus, non ubivis coramve quibuslibet. in medio qui scripta foro recitent sunt multi quique lavantes: suave locus voci resonat conclusus. inanis hoc iuvat, haud illud quaerentis, num sine sensu, tempore num faciant alieno.

(angry Sulcius and Caprius walk about [full of their own importance], horribly hoarse and armed with their little books, both [striking] great fear into bandits; but if someone is honest and keeps his hands clean in life, he could see both as unimportant. Even if you were like [= as bad as] the bandits Caelius and Birrus, I am not like Caprius or Sulcius; why should you fear me? I want no bookshop to have my little books or column to advertise them, for the hands of vulgar men and those of Tigellius Hermogenes would sweat over them. I do not recite to anybody save friends, unless I am forced, not anywhere or before whoever it may be. There are many who recite their writings in the middle of the Forum, or at the baths: an enclosed area echoes the voice pleasantly. This delights the worthless, who not at all ask themselves the question, whether they act without taste or whether the timing is wrong)

It should be noted that the whole passage concerns the activities of the satirists Sulcius and Caprius, with whom Horace compares himself. They are depicted as hoarse (rauci male) from reciting their works in public and trying to sell their books (line 71) in shops, where they are being soiled by the unreliable Hermogenes of S.1.3.129, whom he mentions in the same breath with the vulgar crowd. Horace does not want to see his writings in the bookshops, and he recites only within his circle of friends, and not in public places like the Forum and bathhouses. Worthless people without taste or tact give these kinds of performances.

In my view, Horace gives in S.1.4.65-78 another glimpse of his future programme, in addition to his short-term objective convincing Maecenas. His references to Sulcius and Caprius, and indeed to Caelius and Birrus, are written within the functional frame and show us not only his allegiance to Octavian's cause, but also reveal his intentions with respect to his style of writing poetry embodying political commentary. In lines 65-67 he portrays Sulcius and Caprius as "both striking great fear into bandits." I propose that latronibus in these lines is a functional reference to the criminal actions of the political elite and new rich. ${ }^{158}$ We have seen above that Horace criticized avaritia, ambitio and luxuria, and the social and political risk of unrestrained greed and ambition of the elite in S.1.1. He continued this course in the second sermo criticizing the vulgar conduct and materialistic attitude of the elite and new rich alike, and the threat of their lack of restraint pursuing their own interests. In S.1.3, he referred also to Hermogenes, who exemplifies adaptability and unreliability,

158 I suggest that Horace refers to a specific sort of criminals; hence I do not translate latro as robber, but as bandit. This choice is also consistent with my interpretation of S.1.4.3-5, where the poet refers to ruffians, thief, adulterers, murderers, or otherwise notorious, not describing ordinary criminals or robbers in particular, but individuals in high office, political bandits. 
and to Alfenus, who shows untrustworthiness and dishonesty symbolizing the many who try to force themselves into holding high office and are not deserving such. I mention above that he maintained this position in the opening of S.1.4. Speaking approvingly in S.1.4.3-5 of the poets of Old Comedy who censured "anyone deserving to be described as a ruffian and a thief, as an adulterer or murderer, or as otherwise notorious," he was not thinking of ordinary criminals, but of individuals in high office who were profiteering by criminal action. Thus, it is likely that, although none of their work has come down to us, Sulcius and Caprius were indeed satirists, who in lines 65-67 are depicted censuring rightly the political elite and the new rich acting like criminals. ${ }^{159}$ Horace's next line is a matter of course: if one lives a honest life, there is no need fearing the poems of the two satirists.

In lines 69-70, Horace kills three birds with one stone. Firstly, it is feasible that the two satirists Sulcius and Caprius belonged to the Pompeian party, and also adhered to the Stoics. Ullman $(1917,119)$ observes already that "Horace turns in that passage [S.1.4.14-21] from Lucilius to two contemporary poets, Crispinus and Fannius, with their love for notoriety, so here he turns to the two poets, Sulcius and Caprius, who are addicted to the same weakness.” Thus, Horace connects the four men, and it is interesting to note that Crispinus was a Stoic and that, although Fannius' identity in Horace's work cannot be established, one of the two historical Fannii was a follower of Sextus Pompey, the other was of the anti-Caesarian party (see note 141). It is therefore feasible that Horace lumped together all Pompeian authors, who wrote against Octavian. With respect to the identities of Sulcius and Caprius, I recall the fact that in the treaty of Misenum of the summer of 39 B.C., Sextus Pompey retained control over Corsica, Sardinia and Sicily. My conjecture is that either Sulcius was a native of Sulci, a Sardinian harbour town, and Caprius of the island of Capreae, or that Horace used these two sobriquets to place the men in the Pompeian camp, as the islands between Sardinia and Sicily were well-known as recruiting areas for Sextus. ${ }^{160}$ Further, I conjecture that Sulcius and Caprius were known for publicly lampooning the profiteering conduct of men in the Octavian camp, and keeping the followers of Sextus out of harm's way. Secondly, by introducing the two criminals Caelius and Birrus Horace reinforced his view that some actions of some of the elite and new rich were very reprehensible indeed. Caelius and Birrus are not identified, but according to DuQuesnay (1984, 54 note 163) it is possible that they were also Pompeian supporters referring to Sextus' policy to recruit many bandits and runaway slaves into his navy. According to Gowers $(2012,170)$ "Birrus is possibly from Birra, a gladiator employed

159 For Sulcius and Caprius as satirists, see also Rudd (1956, 49, note 1).

160 DuQuesnay $(1984,56)$ makes a similar point for Tigellius Hermogenes. He conjectures that the latter had defected to Sextus Pompey and says: "What makes this a possibility is that Tigellius was a Sardinian and in 39 Sardinia had been granted to Sex. Pompeius." See also my discussion of S.1.3.124133. 
by Milo," and about Caelius nothing can be found. However, from the context it is feasible that line 69 should be interpreted as "even if you were as bad as the bandits [latronum] Caelius and Birrus" meaning that these two names refer to notorious politicians or their accomplices in Octavian's camp, who carried out the large scale murdering and stealing and consequently were targeted by Sulcius or Caprius. ${ }^{161}$ Thirdly, Horace lifts the veil of his modus operandi censuring political criminals. He says in line 70: when someone carries out those crimes, I will censure him, but not in the way of Caprius or Sulcius, satirists who seek publicity. Horace explains why his targets should not fear him. He asserts in lines 71-78 that, contrary to Caprius, Sulcius, and many other poets, he is not out to sell his poems through the booktrade, or to perform in public or at the baths. His says about his mode in lines 73-74 that he does not recite to anybody save friends, unless he is forced, not anywhere or before whoever it may be. Leach $(1971,627)$, with feeling for Horace's practical approach, notes with dry humour that the poet assures "those whose follies make them liable to satire may be grateful for a satirist of retiring ways who does not bellow his verses publicly (75-6), but saves them for the company of his friends." He will indeed criticize those criminals in a sermo to his friends, men with influence like Maecenas, as he needs to get their approval. But his poems for his friends will be written with the right taste and when the timing is right (line 78). ${ }^{162}$

In the mock conversation of the next passage (lines 78-103), Horace is more specific about the mode of delivering critical poetry, firstly to his friends (lines 78-85), secondly to a group of men who are within the retinue of a patron (lines 86-93), and thirdly to some members of the political elite (lines 93-103). ${ }^{163}$ At first, he recalls the blame which is often put on a censuring poet by quoting a mock person saying: 'laedere gaudes'/ inquit, 'et hoc studio pravus facis.' ("you love to cause pain," some person says, "and you do so on purpose, out of spite.”). Then, Horace puts two rhetorical questions in lines 79-80, which refer back to lines $73-74$ about reciting his poetry only to friends. The questions are unde petitum/ hoc in me iacis? est auctor quis denique eorum/ vixi cum quibus? (where did you find this charge to fire at me? Finally, is the informant someone with whom I was close?). The answer is no, as Horace's friends do not fire charges at each other, and is no again as Horace himself is concerned. He gives a catalogue of malice that in his view cannot be tolerated among friends (line 85). I will quote some examples from the catalogue. First, S.1.4.81-85 reads:

161 Contrary to Gowers (2012, 170), who identifies Caelius and Birrus as armed robbers.

162 For Horace's preference of reading to his friends, see also S.1.6.122-123 and S.1.10.81-88.

163 Leach $(1971,627-630)$ discusses S.1.4.81-103 from the point of view that the "three examples of injurious criticism by ordinary men show what malicious pleasure really is. The persons described might be called non-artistic satirists; although they have a superficial resemblance to Lucilius, they abuse libertas.” (Leach, 1971, 627). 


\begin{abstract}
absentem qui rodit amicum,
qui non defendit alio culpante, solutos

qui captat risus hominum famamque dicacis,

fingere qui non visa potest, commissa tacere

qui nequit: hic niger est, hunc tu, Romane, caveto

(he who slanders an absent friend, who doesn't defend him when someone else finds fault with him, who seeks to obtain the boisterous laughter of men and the fame of a man talking sharply, who can invent things he has not seen, who cannot keep a secret: he is the wicked, of him, true Roman, take heed)
\end{abstract}

This malicious backbiting is the opposite of what one expects from friends: the true Roman of line 85, Horace himself, does not work that way and keeps clear of such a man. Gowers $(2012,171-172)$ states about the first part of the catalogue of malicious behaviour in S.1.4.81-85

if the thoughts [in these lines] belong to H.[orace], which seems more likely [than belonging to his imaginary opponent], given the vehemence of the definition (Kiessling, A. rev. by R. Heinze 1957/1959; Brown 1993/2007), they represent a paranoid delusion that he has been betrayed by one of his own circle, as well as a vehement disavowal of genuine malice.

I agree with Gowers that lines 81-85 are Horace's own thoughts indeed and that the poet disavows genuine malice. In my opinion however, it is certainly not a "paranoid delusion that he has been betrayed by one of his own circle." In S.1.4.81-85, the poet states his views on the correct behaviour among friends in reply to the imaginary rhetorical questions of lines 79-80. Friends should certainly frankly criticize each other if necessary, but this should not be done in a malicious manner, but in a civilized style with concern for one's friends' feelings, as he already argued in S.1.3.25-75. Further, his friends do not tell tales out of school. ${ }^{164}$ I have already mentioned at the end of the discussion of S.1.4.5 that in the case of S.1.4.81-85 Horace's belief in the old Roman values, mos maiorum, is the inspiration for his moral guidance. The passage concerned is about malicious behaviour among friends against which Horace makes his stand. I see the words "hunc tu, Romane, caveto (of him, true Roman, take heed)" in line 85 as a functional reference to the guidance by the old Roman values. Horace addresses all true Romans, including himself, and tells them that such conduct doesn't befit their values, and his. By alluding to the old values and including all true Romans in the group, he enlists them, as it were, as supporters of Octavian, who proclaimed himself as the defender of mos maiorum. This goes with parrhesia as a guide of frank criticism among real friends, who treat each other kindly and thoughtfully.

164 Feeney (2009b, 20) suggests that part of a sermo has "been leaked to a larger public.” It is likely that this happened occasionally, but the gist of the passage is the opposite: friends can be trusted. 
Next, Horace describes events at a crowded dinner party. He replaces in lines 86-93 the friends in the previous passage with dinner guests, not necessarily friends. One of the guests is severely censured in lines 87-91:

e quibus unus amet quavis aspergere cunctos

praeter eum qui praebet aquam; post hunc quoque potus,

condita cum verax aperit praecordia Liber.

hic tibi comis et urbanus liberque videtur,

infesto nigris.

(among whom one likes to asperse everyone in every possible way except him who provides the water, the host; later when he is drunk, he bespatters him as well, when truthful Liber [=Bacchus] reveals the secrets of his heart. Such a man seems to you agreeable, witty and forthright, you enemy of the black-hearted)

Clearly liber in line 90 in conjunction with Liber (= Bacchus) in line 89 do not refer to libertas, freedom of speech, as in line 5 . Here Horace describes the common behaviour of a dinner guest who had too much to drink and who blurts the most unbecoming rigmarole (see also note 131). Horace, who in line 85 condemned scandalmongering among friends saying that someone behaving like that is wicked (niger est), uses the same qualification for the wrong man within the retinue of a Roman patron present at the dinner party in lines 90-91. He asks ironically whether the latter should be considered agreeable, witty and forthright, when the malicious backbiting "friend" is seen as wicked. Freudenburg $(1993,95)$ shows that "the adjectives dicax ('malicious,' [perhaps better: 'talking sharply'] 83), and urbanus ('witty,' 90) are terms commonly ascribed to the scurra mimicus [buffoon in the mimes]. Corbett [1986, 38], [...], concludes: 'The professional scurra's role in mime must then be that of a malicious, witty, gossiping, interfering, arrogant nuisance." We have seen in the discussion of S.1.3.29-34 that Horace rejects this role as his: he chooses that of the gentleman commentator/jester, who speaks freely. Horace underlines his choice in S.1.4.91-93 referring to his views of censurable behaviour when he quotes in line 92 exactly his words of S.1.2.27. Lines 91-93 read:

ego si risi, quod ineptus

pastillos Rufillus olet, Gargonius hircum,

lividus et mordax videor tibi?

(As far as I am concerned, if I laughed because absurd "Rufillus smells of lozenges, Gargonius stinks like a goat," do you find me malicious and snarling?)

We saw when I discussed S.1.2 that the poet writes with disdain about the nouveau riche: Rufillus and Gargonius were ridiculed for their common behaviour in public. Horace's commentary in S.1.2 concerns among other matters the common and unmannerly conduct of an increasing number of members of the elite, but particularly that of the urban upstarts with their materialistic attitude, their hunting for status, and lack of restraint. By quoting exactly the same line of S.1.2.27, the poet asserts in 
S.1.4.91-93 that he will stand by his earlier statement (in S.1.2) about the way he will write his critical commentary: openly without malice. His style will be very different from that of the scurrae who belong to the retinue of the Roman patron, and who inveigh against their host.

The poet discusses the backbiting in the third group, that of the members of the elite, by a mock address in lines 93-103, in which Petillius Capitolinus has the major part. Lines 93-95 read:

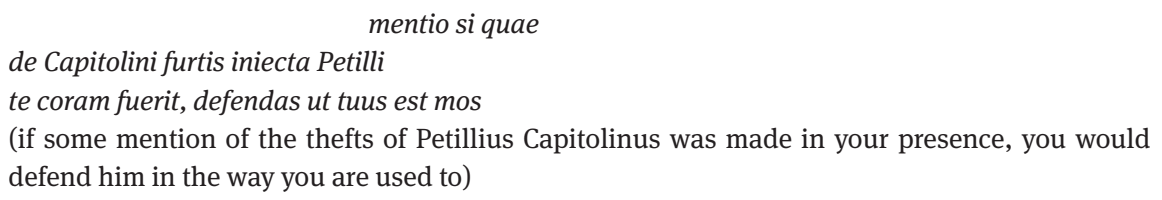

Not much is known about Petillius Capitolinus, who returns in S.1.10.26. There is a story in Porphyrio that he stole the gold crown of Jupiter Capitolinus, when he was in charge of the temple, but was acquitted by Julius Caesar; the story is probably an invention. According to Brown $(2007,135)$ it is more likely that he was accused of embezzlement, as “the charge of stealing Jupiter's crown was a proverbial one," like the charge of stealing the Crown Jewels in England. However, Petillius was well-born, a family that supplied in the Republican era a quaestor and praetor; he himself was a mint-master from 37 B.C. ${ }^{165}$ In short, although Petillius was not a member of the leading aristocracy, he belonged to the political elite.

Horace continues in lines 96-101 the mock example of extreme disloyalty by a member of the elite pretending to defend his mock life-long friend Petillius after the fashion of his class. His plea begins with pretend fine words about their friendship, which one often hears at their gatherings in Roman society salons, but ends with a vitriolic remark. S.1.4.96-103 reads:

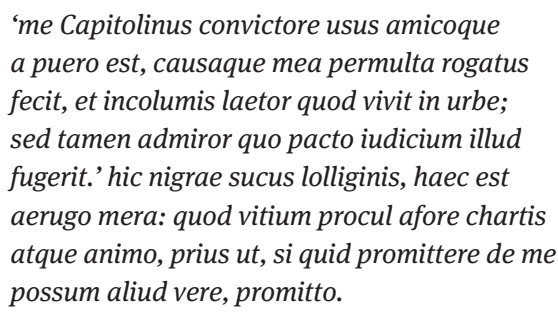

165 For Petillius Capitolinus, see also Gowers (2012, 174); Gundel (1972a). Porphyrio’s text (Meyer, 1874, 212) reads: Petillius autem Capitolinus cum Capitoli curam ageret, coronae subreptae de Capitolio causam dixit absolutusque a Caesare est (but Petillius Capitolinus, when in charge of the temple of Jupiter on the Capitol, is accused of stealing the crown of Jupiter and acquitted by Caesar). 
("Capitolinus has been my companion and friend from boyhood, and he has rendered me very many services when asked; I am glad that he is safe and sound and lives here in Rome, but still I am astonished as to how he escaped at that trial." This is the ink of the black squid, this is pure verdigris. That this fault will be far from my pages and from my mind, as it has been in the past; if I can make any true promise about myself, this I promise)

Aerugo is literally verdigris or copper-rust; in a figurative sense it means: envy, illwill. ${ }^{166}$ Horace says in lines 101-103 about the sting, which is literally in the tail, that he does not intend to apply such malice. Inspired by his understanding of the moral principles embodied in the mos maiorum, he condemns the hypocritical malice of the would-be friend of Capitolinus in lines 96-97. Horace's reaction in S.1.4.93-103 is similar to that in S.1.4.81-85, at the end of his comments on the wrong behaviour among friends, and the ironical questions he asked in S.1.4.90-93, at the end of the section about the objectionable scandalmongering by the wrong type at the dinner party of the Roman patron. The keywords chosen by Horace fit the parties which he speaks about very well. I mentioned above that in lines 81-84 he chose for the party of friends words which express malicious backbiting, the opposite of what one expects from friends. In line 85, he used niger (wicked) condemning this malice. In the case of the man at the dinner party, who asperses everyone in the most insulting manner possible, the poet characterized in line 90 the other guests' reception of his words in typically nouveau riche fashion. They consider him (in line 90) agreeable (comis), witty (urbanus), and forthright (liber). In this way, Horace made a reference to the silly habit of parroting the social standards of the upper classes by the men at the dinner party. The mention of liber in line 90 may even have a double function. It can be interpreted that Horace alludes not only to frank criticism among friends (parrhesia), caricaturing their real relationship, but also to the opinion that freedom of speech was a prerogative earned by the elite in the Republican era. The new rich felt that they also deserved this privilege.

It is noteworthy that Horace uses the word niger (or word-forms) for wicked behaviour in censuring others at three places in S.1.4: S.1.4.85 (among friends, niger), S.1.4.91 (nouveau riche at patron's dinner party, nigris), and in S.1.4.100 (elite dinner, nigrae). ${ }^{167}$ In this passage, Horace has no good word to say for the stealthy manner in

166 For aerugo, see Lewis \& Short (1955, 60): “Envy, jealousy, ill-will (which seek to consume the posssessions of a neighbor, as rust corrodes metals)."

167 The word nigro is used in Ep.2.2.60 with a similar meaning (see also my discussion in section 2.1). With the aid of Brepols' Library of Latin Texts - Series A, 2016 (http:/www.brepolis.net), I found that Horace used the word niger (or word-forms) fourteen times: in the Sermones (10), Epodi (2) and Epistles (2). In nine cases the word relates to matters which have no bearing on the present discussion, such as nigra collyria (black ointment) in S.1.5.30, nigra palla (black robe of Canidia) in S.1.8.23, nigris oleis (black olives) in S.2.2.46, or nigris moris (blackberries) in S.2.4.22. The word nigrum in Huncine solem/ tam nigrum surrexe mihi ! (now, that such a black day occurred to me !) in S.1.9.72-73 is remotely relevant because of the context of the pest who attempts to force his way into the circle of Maecenas. 
which the elite censures their people; on the surface it seems to be civilized, but in reality it is as malicious as it is often the case among friends (line 85) or among the new rich (line 91). He promises that such style will be far from him.

In lines 103-105, Horace apologizes in advance if he were to be seen as too outspoken (liberius) or too jesting (iocosius). Gowers $(2012,175)$ observes that in these two lines "black humour is presented [by the poet] as something on the margins of social acceptability, mildly risky, life-and-soul-of-the-party-ish. Liberius pleads for the same kind of indulgent interpretation as 90 liber did." It should be noted, however, that the contexts of liber in line 90 and of liberius in line 103 differ significantly; "90 liber" describes the wrong kind of talk coming from a drunk (Liber in line 89, see above) who can not control himself, while liberius in line 103 is part of Horace's parrhesia. The scene has changed. Horace observes and describes in lines 93-103 the ignominious behaviour of the elite, and he has thus come near to his own circle of elite friends. Therefore, I interpret lines 103-105 that Horace does not observe and describe others any longer, but has turned round and directly addresses himself to Maecenas and his friends, because he is worried that he overstepped the limits of frank speech. But, I should first explain the poet's views on frank criticism among friends. Michels $(1944,173)$ states that one finds in much of Horace's work a "concern for the welfare of his friends," inspired by his "sympathy with Epicurean doctrine," that is the teaching

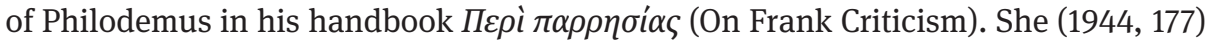
closes her paper with the words that Horace "saw how through the use of Epicurean $\pi \alpha \rho \rho \eta \sigma i \alpha$ Lucilian satire could be used in Epicurean fashion for the instruction of a group of friends. This is the new idea which he is explaining in Serm.1.4, having already demonstrated it in the three preceding satires." Konstan et al. $(2007,8)$ concentrate on the notion that Philodemus' treatise "discloses a form of psychagogy that depends upon the active participation of all members of the community in the correction of one another."168 We saw above that Horace mentions libertas - the contemporary Roman interpretation of parrhesia by Philodemus - indeed as one of the sources in executing his concern for his friends and their moral development, the other being the mos maiorum like in S.1.4.81-85 and S.1.4.93-103. In my opinion, mos maiorum is not at issue in lines 103-105, but frank criticism among friends is (see also the introduction of the discussion on moral guidance at S.1.4.5). In lines 103-105, Horace is worried that he is seen as rising above his station, either as too outspoken and as gone too far in his frank criticism, or as frivolous, while the correction of friends is a serious business. In his apology in lines 103-105, Horace says cum venia dabis which I translate as "when you grant me a favour." He presents himself as a modest and civilized man compared with the nouveau riche and the members of the elite dinner party.

168 For Philodemus and criticism, see Hunter (1985); Konstan et al. (2007, 3-24); Michels (1944). For friendship in the classical world, see Konstan (1997). 
From line 105, a passage follows in which Horace claims that his father taught him the moral lessons which laid the foundation of his outlook upon life. Before considering in more detail his father's role, I will briefly consider S.1.4.105-115, when he summarizes, as it were, the moral vices which he mentioned thus far in the previous sermones. One should note that he presents those in the same sequence as that of S.1.1-1.2. He says in lines 105-106 insuevit pater optimus hoc me,/ ut fugerem exemplis vitiorum quaeque notando (my father, the best of all fathers, accustomed me to that by censuring several vices by his examples, so that I should steer clear of them). ${ }^{169}$

The first vices, which Horace addresses in lines (107-111) refer to those from the first sermo. His pater optimus taught him that he should not become discontented with his lot envying others and grow overambitious like the men of the opening lines of S.1.1: if I live thriftily and frugally, content with what he himself (his father) had provided for me (parce, frugaliter, atque/ viverem uti contentus eo, quod mi ipse parasset). The father recalls both how badly the son of extravagant Albius of S.1.4.28 fares ('Albi ut male vivat filius'; see also note 145), and the poverty of Baius ('Baius inops'). Horace claims in lines 110-111 that this story by his pater optimus about the lots of Albius' son and of Baius taught him an important lesson (magnum documentum), namely not to squander the patrimony ('ne patriam rem/ perdere'). Albius and Baius are unknown to us. Thus, it is not clear whether Albius or his prodigal son, or a Baius or his son lost the family fortune by their immoderation. But Horace makes it very clear what he thinks of the vulgar ways of the new rich. According to Gowers $(2012,177)$ Baius is "perhaps suggesting a connection with Baiae, sybaritic seaside town." Her proposal is feasible indeed, as we have noted earlier that Horace describes in Carm.2.18 the lavish building of villae in Baiae where the houses of the rich partly extend into the sea the cost of confiscating farmland. In Carm.2.18.20-26, the poet paints a moving picture of the evictions of the poor.

In lines 111-115, Horace repeats the second group of vices, which he considered in the second sermo, that is a shameful love for a prostitute (turpi meretricis amore) or chasing adulterous married women (sequerer moechas). He introduces again two men who were possibly known to indulge in these passions, Scetanus who visits prostitutes and Trebonius who makes love to a married woman and is caught in the act (deprensi). Although Scetanus and Trebonius are also unknown, the latter may give a clue to the social class that Horace addresses in those lines. The family did not belong to the top of the Roman elite, but members of the family held political office. C.Trebonius was in Republican times a supporter of Pompey and a tribune of the plebs in 43 B.C., who wrote a letter to Cicero in 44 B.C. (see CIC.Fam.12.16.3). DuQuesnay $(1984,30)$ observes $^{170}$ :

169 For “Horace’s father's” role, see Freudenburg (1993, 33-39); Leach (1971); Schlegel (2000, 93-107 = 2005, 38-51); Yona (2015). See also my discussion of S.1.6.71-82.

170 For Trebonius, see DuQuesnay (1984, 29-31); Gowers (2012, 177). The Latin citations are from CIC. 
Here we find Trebonius celebrating his first taste of that libertas, which he evidently hoped that the murder of Caesar had restored [ut aliquando otiosa libertate fruamur], by composing an invective in the manner of Lucilius [deinde, qui magis hoc Lucilio licuerit adsumere libertatis quam nobis?] as a concrete demonstration of his new-found libertas. The target of his invective was probably M. Antonius, his former friend and the future Triumvir.

It is feasible that Horace, who most likely knew of Trebonius' political activities at the time of Julius Caesar's murder or immediately after, also knew of Trebonius' opinion of Marc Antony when he wrote the fourth sermo between the years 38 and 35 B.C. Marc Antony broke with Octavia in 37 B.C., and he passed his time alternately between military campaigns in the East and Cleopatra's palace in Alexandria, culminating in the Donations of Alexandria in 34 B.C. At the time of writing S.1.4 the tensions between Octavian and Marc Antony were increasing. In addition, men writing in the manner of Lucilius, like Trebonius, were connected with the faction of the Pompeians and were seen as the defenders of traditional libertas. I concur with DuQuesnay $(1984,31)$, who argues that Horace, contrary to the general opinion, says that Octavian, Maecenas and "his friends [are] the true champions of libertas," that is they are traditional and responsible. They are opposed to "licence, the irresponsible, malicious and divisive exercise of freedom with which true libertas is wrongly confused" (DuQuesnay,1984, 30). I propose that Horace by the functional reference to Trebonius in S.1.4.114 kills three birds with one stone. Firstly, by referring in line 114 to Trebonius, the man who wrote an invective against Marc Antony, Horace alludes to the latter reminding readers that Antony is overstepping the mark of true libertas again in his affair with Cleopatra. He also criticizes Antony's affair with Cleopatra sharply in S.1.8 in connection with the threat of Eastern magical practices, in which the Egyptian queen was involved. The allusion to Antony in line 114 is the second occasion that he criticizes Antony; the first time was in S.1.2.55-59, when he censured the sexual escapades of men like Marsaeus which, as I mentioned above, may allude to Antony's adventures with the actress Cytheris. Secondly, Horace makes a statement about his views on true responsible libertas, which is very different from licentious behaviour. Thirdly, the possible link of Trebonius with Marc Antony also substantiates that the poet's criticism of the sexual affairs in S.1.4.111-115 was directed at the political and social elite, the same targets as that of the second sermo.

After the poet's summary of the principal vices and examples of the perpetrators in lines 105-115, Horace quotes in lines 115-126 his mock father's words focusing on "the father's" role in the poet's upbringing. Lines 115-119 are crucial for understanding the role of "the father," or rather quasi-father. He mentions the role of "the father" not only in this passage, but also in the sixth sermo. S.1.4.115-119 reads: 


\author{
'sapiens, vitatu quidque petitu \\ sit melius, causas reddet tibi: mi satis est si \\ traditum ab antiquis morem servare tuamque, \\ dum custodis eges, vitam famamque tueri \\ incolumem possum;' \\ ("a philosopher will explain to you the dos and don'ts: I am satisfied, if I can preserve the way of \\ life handed down by our ancestors, and can keep your life and reputation unimpaired, so long \\ as you need a guardian”)
}

I will argue below that Horace's quote of his “father's" words does not necessarily mean that the father actually spoke those. It is also possible that the poet again makes here two points through the medium of "his father." Even so, the first point is that he does not want to be guided in moral matters only by the teachings of philosophers, but also by following the traditional Roman moral teachings handed down to him. We saw already at several places in S.1.4 that the mos maiorum was of great importance to him. He was an adherent of Epicureanism, and he used Philodemus treatise "On Frank Criticism" as a guide. Yet, he also knew the Stoic dogmas, as he showed for example in S.1.3.99-124, when he used both Stoic and Epicurean tenets to deliver his commentary on social and political evil. He also demonstrated at many other occasions in S.1 that he knew Stoicism well enough to understand the thinking of the Stoic opponents. The second point is that "the father's" words traditum ab antiquis morem servare (preserve the way of life handed down by our ancestors) can hardly be interpreted as referring to - paraphrasing Gowers $(2012,178)$ - "notable ancestors of H.[orace]'s father, an ex-slave."

We saw that Horace writes in S.1.4.105-108 that his father taught him the moral lessons which laid the foundation of his outlook upon life. I do not interpret these lines as his father actually sitting with Horace teaching him moral philosophy, but that Horace says that the way of life is handed down to him by the Roman forefathers in general. The role of "the father" in the narrative is being a link between the generations symbolizing the continuity of the traditions. I do not interpret the passage S.1.4.103133 as autobiographical, but as Horace expressing that he grew up in a milieu having respect for the old Roman values. He confirms this again in a later sermo, S.1.6.76-78, when he narrates that his father took him to Rome for his education. He writes: sed puerum est ausus Romam portare, docendum/ artis, quas doceat quivis eques atque senator/ semet prognatos (but he dared to take his boy off to Rome, to be taught those studies which any knight or senator would have his own children taught) (see also section 1.3.2, and discussion of S.1.6). Horace was to be educated within a milieu of the social elite (eques atque senator) in Rome, which likely meant that he would move within circles where the old values were still upheld. 
When Horace says in lines 120-121 sic me/ formabat puerum dictis, I read this as: it formed my character as a boy with sayings like these. ${ }^{171}$ Thus, my interpretation of the passage differs much from that of Leach $(1971)$. She $(1971,618)$ observes that "so specific and well drawn is Horace's picture of his father and himself, that it has had unquestioning acceptance as pure autobiography." Next she explores Horace's account of "his father's" teaching and proposes that it "is closely analogous to a scene in that play [i.e. Terence's Adelphi].” Leach suggests that Horace's father has been modelled after Terence's Demea, as both share the same moral convictions and didactic methods, relying on traditional values. ${ }^{172}$ In addition, Freudenburg $(1993,37)$ points out that a literary resemblance exists between Terence's and Horace's texts as follows. In TER.Ad.417-419, Demea rehearses his teaching with the slave Syrus in "repeated short bursts of thought, each introduced by hoc [4 times]." This is mirrored by Horace in lines 134-137: ${ }^{173}$

'rectius hoc est:

hoc faciens vivam melius: sic dulcis amicis

occurram: hoc quidam non belle; numquid ego illi

imprudens olim faciam simile?'

("this is better: doing this, I shall live more happily: this is how to make a good impression on my friends: that wasn't nice of so and so: might I one day unintentionally do a similar thing?”)

While this literary resemblance looks very convincing indeed, some important differences in content exist between the two texts. Leach $(1971,619)$ identified already that the seeming obedient son of Demea who lived with his father on the farm "breaks free from the harsh discipline of his father and enlists his city brother's aid in the abduction of a courtesan," and Freudenburg $(1993,38)$ concludes that "as the plot unfolds, it becomes apparent that Demea's methods have been entirely unsuccessful," while Horace is portrayed as a perfect and obedient son.

Studying the fourth sermo for the political content from a functional point of view, I postulate that the significance of the poet's many lines about the moral vices and their perpetrators is overlooked. The first four sermones are closely connected, and S.1.4 is, metaphorically speaking, the head on top of the body of S.1.1-1.3. The fourth sermo draws together the views which the poet expressed in the first three poems. In lines 107-115 he gives his final summaries of respectively S.1.1 and S.1.2. When, from line 115 until the end of the poem "the father's" moral teaching is compared to that of philosophers, the tone becomes more personal and intimate. I propose that lines $115-143$ pertain to $S .1 .3$, which is - as we have seen above - the

171 I owe the rendering of $m e$ as "my character" to Brown $(2007,51)$.

172 For the supposed model of Terence's Adelphi, and the autobiographical nature of S.1.4, see also Freudenburg (1993, 33-39); Leach (1971); Oliensis (1998, 18-26).

173 For the translation of S.1.4.134-137, I have followed some of the suggestions by Gowers $(2012,180)$. 
sermo that concerns his position among friends. I suggest that S.1.4 does not only concern Horace's relationship with his supposed literary "father” Lucilius (I borrow this expression from Schlegel, 2000, 106), but also - and indeed primarily - shows Horace's conviction that his role as an author of poetry with political commentary is to expose the many social and political evils and shows his search for an effective way of expressing. This is what a critical poet is for, as he says in lines 120-122:

\footnotetext{
sic me

formabat puerum dictis; et sive iubebat

ut facerem quid, 'habes auctorem quo facias hoc';

(it formed my character as a boy with sayings like these, and if it [my character] was telling me to do something, it would say "you have one on whose authority you can do this")
}

I interpret the latter lines as saying that he learned how to follow his own counsel. The last bit of paternal advice is given in lines 124-129 beginning with the rhetorical question 'an hoc inhonestum et inutile factu/ necne sit addubites, flagret rumore malo cum/ hic atque ille?' ("are you in doubt whether or not this is dishonourable and useless, when so and so is grilled by bad repute?"). The answer, given in lines 128129 , is that young people are often restrained from vice by the example of scandal experienced by someone (sic teneros animos aliena opprobria saepe/ absterrent vitiis). Next, Horace reflects on the moral lessons learned in his youth in lines 129-131:

ex hoc ego sanus ab illis,

perniciem quaecumque ferunt, mediocribus et quis

ignoscas vitiis teneor.

(Thanks to this method [of giving examples to the young], I am free from those faults, which bring ruin, although I am in the power of minor, innocent ones)

“Instilling morals by example to the young” (Gowers, 2012, 179) keeps young people from serious moral faults, as Horace, generously admitting his own minor defects, testifies in lines 129-131. He expects, however, that these minor failings will mend with time, a frank friend, or reflection (abstulerit longa aetas, liber amicus,/ consilium proprium, lines 132-133). Liber in line S.1.4.132 refers to the concept of parrhesia as meant by Philodemus in his treatise. At this stage, it is useful to briefly recapitulate Horace's use of the notion of parrhesia in S.1.4. The word libertas (parrhesia) appears for the first time in the poem at S.1.4.5 praising the poets of Old Comedy, who censured men holding high public office with great freedom of speech (multa cum libertate notabant). There is, however, an essential difference between S.1.4.1-5 and S.1.4.132. In the former passage, he describes censure of thirds which should be frank and free. In the latter, he is concerned with the issue of behaviour among friends, a discussion with equals. Horace touches in S.1.4.132 upon the true meaning of Philodemus' views in his treatise "On Frank Criticism." Konstan (2007, 5-6) puts this as follows: "It is abundantly clear in Philodemus' treatise On Frank Criticism that the topic of frank 
criticism in moral reform is part of the topic of friendship. Members of the group admonish and censure each other in friendship." Horace counts on his friends to correct his minor faults.

Thus, the passage of lines 103-143 concerns firstly his priorities for his programme of writing politically oriented commentary (to be content and avoid avarice in lines 107-111, and to shun vulgar passion in lines 111-115), and secondly his "father's" education as the foundation for the position within his circle of friends (lines 115-143). That is what "his father" taught him in the first place. But why does Horace quote "his father" in such detail? Why does he not simply state that he is much in sympathy with the old Roman values, and why does he need "his father's" authority? I intend to show that the passage about the role of "his father" relates directly to S.1.3, and particularly to the last but two lines 139-140. When I discussed S.1.3, I mentioned that Horace closes the poem with a few lines about his own fortunate circumstances. I concur with DuQuesnay $(1984,36)$, who also argues that Horace at the end of the third sermo (in S.1.3.139-140) refers to himself: et mihi dulces/ ignoscent, si quid peccaro stultus, amici (and my dear friends will forgive me if I - fool I am - make a mistake). He was accepted within a circle of men of great charisma and importance, real friends. The words dulces amici are repeated in S.1.4.134-136 when the son says: "rectius hoc est;/ hoc faciens vivam melius; sic dulcis amicis/ occurram ("this is better: doing this, I shall live more happily: this is how to make a good impression on my friends). Both at the end of $S .1 .3$ and that of S.1.4, Horace expresses his contentment with the way his career advances. Oliensis $(1998,18-26)$ also recognizes that he wrote these lines with the progress of his position within the circle of Maecenas in mind. She $(1998,26)$ argues that S.1.4.133-137 means that the socially inferior self-made man Horace will enter a

self-improvement program. It is this self-improvement program, Horace claims, that makes him dulcis amicis, 'dear to his friends' - a fine candidate for the friendship of the judicious Maecenas, among others. Only in this indirect and laudable fashion can Horace's satiric art be said to have won him his new position in society.

However, she and I differ on the points Horace makes concerning his programme of action. She $(1998,20)$ also maintains that "if Horace focuses attention on the proper selection of satiric targets, one reason is his desire to reassure Maecenas that he will not level his satire against him.” I propose a different interpretation to that of Oliensis, namely that Horace's wish was to write critical commentary on contemporary political issues, and that he did not intend to exclude the political leadership, that is Octavian and Maecenas among others. The second book of Sermones, written between 33 B.C. and 30 B.C., contains two poems (out of eight) with critical commentary on contemporary social and political issues, S.2.2 and S.2.8. The book of Epodi, written 
in the same period, has seven (out of seventeen) such poems. ${ }^{174}$ Horace, an unknown man from provincial Venusia, must first demonstrate that he is a reliable member of the circle of Maecenas, but one with an independent mind who will speak freely. That is what he does at the closure of S.1.4, and indeed in S.1.3 and S.1.5, written between 38 B.C. and 36 or 35 B.C. DuQuesnay states that "among his [Horace's] amici were Caesar (Octavian) and Maecenas; among the faults which they pardoned, the reader will recall, [was] Horace's adherence to the Republican cause at Philippi.” Horace is stigmatized firstly by his Venusian origin: we have seen in section 1.3.2 that Venusia was punished, as the town had not remained loyal to Rome in the Social War, while the majority of Latin towns maintained their support for Rome. Thus, it is likely that Venusians were considered unreliable by leading Romans. He makes this point again in S.1.5. Secondly, Horace joined Brutus' party and fought at the wrong side at Philippi. Thus, he has to demonstrate that he is of good political stock, who upholds the traditional Roman values, and that he shook off the last vestiges of Republican leanings.

Leach (1971) does not recognize that Horace's representation of "his father" is not autobiographical, but I concur with Schlegel $(2000,93)$ that it is poetic fiction, who argues "that Horace tells us [in S.1.4] very little about his life.” However, I differ from Schlegel when she states "that furthermore the 'information' he supplies is motivated by its poetic context." She continues with the words that Horace is not "confessing his life to his books. Satires 1.4 and 1.6 are the well-known loci of Horace's upbringing by his father, told in the context of Horace's relation to Lucilius, his satiric forebear, and to Maecenas, [...]. All four figures - father, son, satiric predecessor, and patron - are artifacts of the poet's generic construction, dramatis personae structured to provide a definition to Horace's satiric art." I have explained above and I will explain in the discussion of S.1.6, that I agree with the opinion that Horace, among other matters, indeed writes in S.1.1 - 1.4 about his views on censure poetry. However, I do not support the view, that Horace explores and defines his satiric art by means of the figures of

174 For the date of writing of Epod., see note 7. In S.2.2, Horace criticizes the social consequences of the land confiscations by, amongst others, Octavian (see Weeda, 2010, 141-142; 340). In S.2.8, where Maecenas is the guest of honour at a dinner party arranged by a nouveau riche, Horace shows that mixing the old elite and the new rich is a danger to a healthy society (see Weeda, 2010, 146-148; 340). In Epod.2, Horace condemns the cynical attitude of Rome's leading circles towards the situation after the land expropriations (see Weeda, 2010, 153-154; 340). In Epod.4, the poet criticizes the rise to powerful positions of too many new men, who are incompetent and not to be trusted (see Weeda, 2010, 155; 340). In Epodi 5 and 17, Horaces expresses his concern about the dangers of black magic, the growing Eastern influence, and the alliance of Marc Antony and Cleopatra (see my discussion of S.1.8). Epodi 7, 9 and 16 pertain to the civil war. In Epod.7, he censures Antony, Sextus Pompey and particularly Octavian for the ongoing war and power struggle (see Weeda, 2010, 157-159; 340). In Epod.9, Horace focuses on the battle at Actium; he is critical of Octavian's military qualities (see Weeda, 2010, 160-163; 340). In Epod.16 he also criticizes the renewal of the war, but he expresses his expectation of better times (see Weeda, 2010, 166-169; 340). 
"his father" and Maecenas. Firstly, I use the words "censure poetry" advisedly as he did not write much satire; the greater part of his social and political criticism can be found in other genres. Thus, Lucilius was not Horace's satiric predecessor, although he learned from Lucilius that frank and free criticism had its place and deserved to be listened to (see also my observations on this subject in the discussion of S.1.10). Secondly, in my view, "his father" in this passage is not Horace's biological father, but symbolizes the sound ethical and political priorities of his background, and Maecenas' role is that of the man who needs to be convinced that Horace will be a worthwhile associate (see also the discussion of S.1.6.78-80, and note 223).

I mentioned above that the passage from line 115 concerns his position within his circle of friends. First, in lines 115-131 he explained that his political background was sound. Next, from line 131 he looks forward to the pleasure of the company of his friends: the word amicus appears twice, in lines 131 and 135. However, there are other pleasures. There will be time for reflection (consilium proprium), relaxing on a couch (lectulus) or strolling in the colonnade (porticus). He will take to self-examination, as he says in lines 134-140, which I partly quoted above. Some thoughts he will keep to himself, but others he will commit to paper. In S.1.4.137-140 he says:

\author{
haec ego mecum \\ compressis agito labris; ubi quid datur oti \\ illudo chartis. hoc est mediocribus illis \\ ex vitiis unum; \\ (these [thoughts] I consider with myself, lips sealed; when I have some spare time, I waste paper. \\ This is one of those minor failings)
}

Gowers $(2012,181)$ sees in lines 137-138 a reference to, "the scurra of [S.1.4.]86-89, who blabs about his friends behind their backs" at a dinner party. In my view, S.1.4.115-143 refers to his position within his circle of friends. Consequently, I read S.1.4.131-140 to echo S.1.4.17-18 and partly S.1.4.81-85. Horace is not going to give in to malicious backbiting like the untrustworthy friend in S.1.4.81-85, he keeps his lips shut tight. He will conduct himself in such a manner, that he can achieve what he intended and partly wrote down tongue-in-cheek in S.1.4.17-18 di bene fecerunt inopis me quodque pusilli/ finxerunt animi, raro et perpauca loquentis (the gods be praised for creating me with a weak intellect and petty spirit, one that speaks rarely and scantily). His programme is to write down for his friends his thoughts when he can, with restraint and in simple language, not hasty, but in a polished and attractive style considering his words carefully. In the words of Anderson $(1982,16)$ "In his [a Roman citizen's] social intercourse he might be 'free' among friends of the same station. A true friend would express himself frankly and honestly, even when such freedom meant that he had to criticize a close companion."

Finally, the sensible Horace surprises us in the last four lines of the poem. Any of his friends who refuse to listen to his poetry will face a group of his colleague poets coming to his aid (multa poetarum veniat manus auxilio quae/ sit mihi). Earlier in the 
same poem, in lines 41-42, he wrote that one would not consider anyone like him, who writes something resembling the language of conversation, a poet (neque si qui scribat uti nos/ sermoni propiora, putes hunc esse poetam), but at this stage he considers himself a poet and implicitly elevates sermo to true poetry. ${ }^{175}$ I suggest that Horace's statement in line 142 nam multo plures sumus (for we are much in the majority) is not a "comic hyperbole" (Brown, 2007, 138), but a confident statement that he and a number of his poet-friends within the circle of Maecenas have an important contribution to make to the debate about the major contemporary political and social issues. He warns his readers in the last line of the poem that they will do their utmost to convert them to their points of view, like the Jews do, known for their zeal and tenacity. The group of poets around Maecenas was clearly not the majority of the whole circle. As far as we know, nine other poets, apart from Horace, belonged to the group around Maecenas, of whom Horace mentions in S.1.5 Virgil, Varius Rufus, and Plotius Tucca as his intimates (see also note 45). In addition, he will also say in S.1.10.81-90 that he has a warm place in his heart for the elegist Valgius Rufus, the poet Octavius Musa, the tragedian Asinius Pollio, and the dramatic writer Aristius Fuscus, who was a special friend. White $(1993,40)$ states "that the people who gathered around men like Maecenas and Messalla did not form closely knit groups pursuing distinctive ideologies.” I (2015, 54-84) argue that Virgil's Caesarean sympathies and distinct political views are already visible in the Eclogae, of which most (7 out of 10) the politically most outspoken poems - were written between 42 B.C. and at the latest 40 B.C. ${ }^{176}$ This was before Virgil's relationship with Maecenas. White $(1993,40)$ asserts that "Varius also was writing poetry with political overtones in the latter 40s. We do not know that it was pro-Caesarean, but we do know that it was anti-Antonian.” Thus, when Horace was invited to join the circle, he came into the company of at least two poets - and perhaps more if some of the poets mentioned in S.1.10 belonged already to the circle - whose poetry also held political commentary, although we do not know the details of that in the case of Varius. This may have been the reason for Horace asserting in these last lines that they, although not great in number, but not the least of poets, would be a force to be reckoned with in the discussions of political issues: he would strengthen that force by the power of speech in his sermones.

175 For the question whether satire was seen as true poetry, see Freudenburg (1993, 119-128; 145-150) and Gowers (2012, ad loc.). I discuss these issues above w.r.t. S.1.4; detailed discussions of the general issues are given in Freudenburg (1993).

176 For the likely dating of Ecl.1 in 41/40 B.C., see Weeda (2015, 59, 79); Weeda \& van der Poel (2016, 196); of Ecl.2 in 42 B.C., see Weeda (2015, 60, note 76); of Ecl.3 in 42/41 B.C., see Weeda (2015, 61); of Ecl.4 in most likely 40 B.C., see Weeda (2015, 61); of Ecl.5 in about 40 B.C., see Weeda (2015, 65); of Ecl.6 is not discussed explicitly, but most likely shortly after 40 B.C., see Weeda (2015, 65); of Ecl.7 most likely after 40 B.C., see Weeda (2015, 69); of Ecl.8 in likely 35 B.C., see Weeda (2015, 60 note 76; 70); Weeda \& van der Poel (2016, 196); of Ecl.9 in 40 B.C., see Weeda (2015, 74, 79); Weeda \& van der Poel (2016, 196); of Ecl.10 in 41/40 B.C., see Weeda $(2015,79)$; Weeda \& van der Poel $(2016,196)$. 


\subsubsection{Sermones 1.5 and 1.6: Horace's Credentials for Maecenas Continued: A Journey to Brundisium; Youth and Education in Venusia and Rome}

Sermones 1.5 and 1.6 are often read as autobiographical poetry. S.1.5 is supposed to record a historical journey from Rome to Brundisium that Horace made in the company of Maecenas, and S.1.6 is seen as a true report of the young poet's days in Venusia and his first experiences in the company of Maecenas. We have seen in section 2.2.2 that Horace narrated for the first time some "personal experience" in S.1.4, when he wrote about his own education by his "father." I suggest that he wanted to show that he was of good political stock, which upholds the traditional Roman values, and thus a worthy member of the circle of Maecenas. I intend to demonstrate that he continued to take this line in the fifth and sixth sermones.

In Sermo 1.5, Horace relates his (supposed) taking part in a journey from Rome to Brundisium. He describes travelling in the company of amongst others Maecenas, Virgil, Varius and Tucca. ${ }^{177}$ It is generally held among scholars that Horace modelled S.1.5 on Lucilius' Iter Siculum. ${ }^{178}$ I note that I do not interpret S.1.5 as a poem in which Horace intended to emulate Lucilius. I intend to demonstrate that the fifth sermo is the poet's next step in presenting himself as a worthy member of the group of men around Maecenas - a leading theme of the previous sermones. Further, I mentioned in section 1.4, that the historicity of the journey is very doubtful, and that the latter is most likely Horace's poetic fiction (see Musurillo, 1955). I concur with Musurillo $(1955,162)$, who argues that "in view of the meagerness of our historical sources, and considering what seem to be in Horace conflicting details, can we be sure that the satire is not simply a poetic fiction, a composite picture perhaps of journeys made at different times and bound together as a jeu d'esprit in imitation of Lucilius?" Contrary to this view, Campbell (1970, 82-83; 92-93; 166-167) firmly reads $S .1 .5$ as an account of a real journey which Horace made in Maecenas' company. He (1970, 92-93) states that "between 40 B.C. and the spring of 37 inclusive, he [Maecenas] made no less than four separate journeys to Brundisium [...]. It is now generally agreed that the journey

177 For S.1.5, see Anderson (2010, 37-38); Brown (2007, 138-150); Connors (2005, 131-135); Cucchiarelli (2002); DuQuesnay (1984, 39-43); Freudenburg (1993, 201-205; 2001, 51-58); Gowers (2003, 76-78; 2005, 48-57; 1993/2009; 2012, xi, 182-214); Mayer (1989, 10-11); Meijer (2017); Musurillo (1955); Oliensis (1998, 26-30); Rudd (2007, 54-64); Sallmann (1974), who also gives a review of the scholarship. For the friendship of Horace and his companions of the trip, see Mayer (1989, 10-11).

178 Porphyrio (Meyer, 1874, 213) stated already that Lucilius' Iter Siculum was the model for S.1.5: Lucilio hac satura aemulatur Horatius iter suum a Roma Brundesium usque describens, quod et ille in tertio libro fecit (Horace, who describes his journey from Rome to Brundisium, emulates in this satire Lucilius what he also described in his third book). For a summary of Lucilius as a model for S.1.5, see DuQuesnay (1984, 40-43); Freudenburg (1993, 201 note 51; 2001, 51-52); Gowers (2012, 10; 184); Sallmann (1974, 182-184); Williams (1968, 569-570). A detailed discussion of the issue in Barchiesi \& Cucchiarelli (2005, 213-215); Fiske (1966, 306-316); Fraenkel (2002, 105-112); Rudd (2007, 54-64). 
described in Satires, I.V [...] took place in the Spring of 37.” DuQuesnay $(1984,40)$ agreeing that "of all the satires, this is the one most obviously modelled on a famous poem by Lucilius" takes the same stand when he states that "the journey, then, which Horace is describing certainly took place, as his contemporaries would be only too well aware." According to Oliensis $(1998,27)$, Horace went on this journey as "the naming of so many potential witnesses suggests that he did." ${ }^{179}$ We saw in section 1.3.1 (Autobiography in Horace's poetry) that Gowers (2003) offers a very useful model to understand the historicity of Horatian poetry. In addition, an anonymous reviewer pointed out that "Gowers' very broad interpretation of the word 'autobiographical' clearly encompasses poetic fiction." Yet, as I stated in my discussion in section 1.3.1, I will continue to apply both the concepts of poetic fiction and autobiography knowing that those two are interwoven and serve for depicting Horace's life-story. In the case of S.1.5, Gowers $(2009,159)$ sees the "autobiographical" elements and the fictitious details of the journey as "a simulation of a real adventure." Gowers $(2009,160)$ states that

it would be a mistake to read the poem in the context of works like the itineraries or Julius Caesar's lost Iter, which sounds like a logbook of a Roman route. Horace has something else on his mind. This is in quite another sense a poetic fiction: not so much a conflation of journeys as an exercise in writing Horatian satire.

I concur with Gowers that S.1.5 "is in quite another sense poetic fiction," and that Horace "had something else on his mind." I suggest, however, that the poem is neither a description of a real journey nor "an exercise in writing satire.” In my view, Horace had something very different on his mind, that is a description of fictitious events because his objective for S.1.5 (and indeed the other poems in S.1) was to present to Maecenas his views on their relationship. We also saw in section 1.3.1 that it is likely that Horace considered that this was best done by using the form of the first-person persona (Horace) who presents himself as engaged in fictitious events. This enabled Horace to give his commentary on those events or on the individuals involved, while Maecenas received the poet's opinion and could recognise those as fiction but still

179 For the historicity of S.1.5, see also Anderson (1955/1956); Barchiesi \& Cucchiarelli (2005, 213215), and Cucchiarelli (2001, 15-70), both authors are not explicit, but I understand them to say that the journey took place in reality; see also DuQuesnay (1984, 40); Gowers (2009, 157-160; 2012, 183 184); Fraenkel (2002, 105); Meijer (2017) in his engaging and instructive book about the Via Appia (published in Dutch) takes the historicity of S.1.5 for granted. He $(2017,14)$ states: "Only few wrote about their experience travelling the road. The poet Horace is the only one who gives a full account. He travelled in 37 B.C from Rome to Brundisium and described his experiences in a long satire [S.1.5]." (the translation from the Dutch is mine); Musurillo (1955); Rudd (2007, 54), who states: "We do not know for certain which [conference Maecenas' party travelled to], but that does not oblige us to accept the view held by Musurillo and others;" Williams (1968, 569-570). For S.1.5 as a form of travel-writing, see Gowers (2012, 183-184). 
consider the factual points that Horace made. This way Horace could arrange an informal setting for the interchange of views and Maecenas could choose whether to react or to listen.

I will commence by briefly recalling the narrative of S.1.5 including the different views on some aspects of the context of the poem, such as the purpose and the dating of the "journey." Next, I will analyse the poem in detail. Then, I consider the authenticity of the "journey" and I will especially examine two aspects of the text, that is firstly the route of the journey, and secondly the differences in content and detail of Horace's description of several parts of the voyage. Finally, I will present my view on the theme of the sermo.

At this stage, I will relate Horace's narrative as given in S.1.5 irrespective of my views that the account is not grounded on a historic journey. I divide the "journey to Brundisium" into three parts: (1) Rome to Trivicum (some 30 miles Northwest of his hometown Venusia), (2) the route between Trivicum and Rubi, and (3) from Rubi to Brundisium.

After leaving Rome by the Via Appia, Horace spends the night at a modest inn at Aricia. It is not clear from the text whether he stayed there on his own, or with some fellow voyagers. Although he tells us in lines 2-3 that his companion is Heliodorus, by far the most learned of all Greeks (rhetor comes Heliodorus,/ Graecorum longe doctissimus), this Heliodorus cannot be identified. Gowers $(2009,166)$ suggests that the comes "might be the Heliodorus who wrote a poem called Theamata Italica, 'Sights of Italy' (or Thaumata Italica, 'Miracles of Italy') [of which 12 lines survive]. It is even more probable that Horace means that he did not take a man at all, but a book, a kind of 'Companion Guide to Southern Italy'." ${ }^{180}$ If $S .1 .5$ were a form of travel-writing, Horace would presumably have told us something about Aricia, the hometown of Octavian's family the Atti, or about the villa which Julius Caesar built in the town. Perhaps Horace alluded to the Theamata Italica because Heliodorus' book contained such information. In lines 3-23 the Forum Appi gets a brief mention, followed by an account of the boat trip through the canal in the Pomptine marshes. In the Forum Appi Horace experiences his first physical trouble of the journey, a stomach upset caused by the water, that was very bad (hic ego propter aquam, quod erat deterrima, ventri/indico bellum) (lines 7-8). He watches his companions eat their dinner.

Some form of travel-writing starts in line 9. After dinner, at nightfall, they board a canal boat, which is packed full: lines 12-13 say: 'trecentos inseris: ohe/ iam satis est!' ("you packed in three hundred [passengers]: ho there, that's quite enough!"). In the boat, Horace experiences the second trouble within a day. Lines 14-18 say:

180 See also Kiessling (1959, 91); Gowers (2012, 187-188). 
mali culices ranaeque palustres

avertunt somnos, absentem ut cantat amicam

multa prolutus vappa nauta atque viator

certatim: tandem fessus dormire viator

incipit

(bad midges and frogs from the marshes drive the sleep away, while the boatman, sozzled with much vapid wine, sings of the girl he misses and a passenger vies with him. At last, the tired passenger falls asleep)

After describing a night without sleep, caused by midges, frogs and a drunken boatman, Horace touches in lines 18-22 upon a further frustration created by personal discomfort: the delay of the barge caused by the lazy boatman who lets the mule graze on the bank and snores away lying on his back (stertitque supinus) (line 19). ${ }^{181}$ The boat has come to a standstill, until a hot-headed (cerebrosus) passenger gives boatman and mule a thrashing and gets the barge going again. Line 23 says that eventually, at ten o'clock in the morning they disembark (quarta vix demum exponimur hora) and in lines 25-26 Horace reports that they had a late breakfast and crept for three miles going uphill to Anxur (modern Terracina), laying upon her dazzling white rocks, which can be seen from afar (milia tum pransi tria repimus atque subimus/ impositum saxis late candentibus Anxur). Here in Anxur, where the Via Appia hits the sea, Maecenas and Cocceius, who had obviously travelled by sea, were to meet the party. Lines $27-29$ say:

huc venturus erat Maecenas optimus atque

Cocceius, missi magnis de rebus uterque

legati, aversos soliti componere amicos.

(here noble Maecenas and Cocceius were to arrive, both sent as ambassadors on important business and experienced in bringing together friends who were opposed)

Before reporting their arrival, Horace informed us of another of his physical troubles in lines 30-31, that is the necessity to treat his inflamed eyes (conjunctivitis?) with a black ointment (hic oculis ego nigra meis collyria lippus/illinere). The manner in which Horace narrates the discomforts of the first two days, such as his stomach troubles and the boat journey with the crowded conditions, a sleepless night, the delay of the boat and his sore eyes are not only well-known elements of travel-writing, but serve also a very different purpose. Horace mentions the contrast of the comfortable arrival of Maecenas and company in Anxur in order to show that travellers like himself are willing to suffer hardship and discomfort in the service of Maecenas.

181 A side effect of the mention of frogs in line 14 is that the season in which the journey took place can be determined. The season is in turn significant for the dating of the poem. This has been studied by Gow (1901), who, after consulting some eminent authorities on frogs, concluded that Horace travelled in the spring. See also Campbell (1970, 93); Musurillo (1955, 161). 
He reports their arrival in lines 31-33:

interea Maecenas advenit atque

Cocceius Capitoque simul Fonteius, ad unguem

factus homo, Antoni non ut magis alter amicus.

(Meanwhile Maecenas arrives and Cocceius and with them Fonteius Capito, a gentleman to his fingertips, so much so that no one is a better friend of Antony) ${ }^{182}$

The passage of lines 27-33 tell us that two experienced (soliti) diplomats, Maecenas and Cocceius, joined the party in order to settle the problems between two friends, which is generally interpreted as a mission to repair the Triumvirate. Maecenas and Cocceius are soliti as they were both involved in the negotiations which resulted in the Treaty of Brundisium in 40 B.C., and the marriage of Antony to Octavia. ${ }^{183}$ Thus, the poem may refer to a diplomatic mission of Maecenas, but we cannot know which one. In the secondary literature, three possible reasons for Horace's journey in Maecenas' company to Brundisium are considered. These are either the diplomatic mission by Maecenas to Brundisium in 40 B.C., where Octavian and Antony signed the treaty, or Maecenas' journey to the town for a crossing to Athens where he was to meet Antony in 38 B.C., or the signing of what became the Treaty of Tarentum, when Antony could not enter Brundisium in 37 B.C. ${ }^{184}$ Musurillo $(1955,162)$ argues "that it is a useless task to attempt to assign any specific date to the events of the Journey to Brundisium, or to try to sort out details that might be (a) historically true, (b) pure fiction, (c) imitations of Lucilius, (d) plausible 'poetic coloring' (as, e.g., perhaps the gnats, the frogs, and the rain-washed roads)." The uncertainties about the actual journey causes Musurillo to propose that the journey is not historical but poetic fiction. ${ }^{185}$ Gowers $(2009,159)$ writes that "none of them (Treaty of Brundisium of 40 BCE; the Treaty of Tarentum

182 I owe the rendering of lines 32-33 to Gowers (2012, 194-195).

183 For the involvement of Maecenas and Cocceius in 40 B.C. in Brundisium, see Gowers (2012, 193); Pelling (1996, 17-19).

184 Anderson (2010, 36-38) states that the poem refers to a journey to Brundisium in 40 B.C. According to Bowditch $(2010,59)$ the poem refers to the trip to Brundisium in 38 B.C. Campbell (1970, 93 ) is certain that "it took place in the Spring of 37." Gowers $(2012,183)$ states that 37 B.C. is the most likely option. See also DuQuesnay (1984, 39-41); Gowers (2012, 212-214). According to Rudd (2007, 54) "we do not know for certain which conference."

185 For the uncertainties about the progress of the supposed journey, see Gowers $(2012,204 ; 205)$ re. line 71 and lines 77-93; Musurillo $(1955,159)$ writes: "there is the problem - admittedly not an important one - of determining the exact number of days Horace's party required for the journey." He found in the scholarly literature a range of twelve to seventeen days. Sallmann $(1974,187)$, referring to Musurillo, states: “daß die Zahl der Übernachtungen und damit die Gesamtzahl der Stationen durchaus nicht klar ist: die Gelehrten zählen zwischen elf und siebzehn Tagen” (that the number of overnight stays and thus the total number of stages is absolutely unclear: scholars count between eleven and seventeen days). 
of spring 37; and a meeting in Athens between Octavian and Antony in 38 BCE) is quite consistent with Horace's account.” I discussed above in the opening passage of the examination of the present poem her $(1993 / 2009,160)$ argumentation that it would be wrong to read S.1.5 as an itinerary, and that Horace had something else on his mind, namely an exercise in writing satire. In her paper she develops further the literary reading of S.1.5. She $(1993 / 2009,160)$ argues that the poem reflects "all the tangled ramblings, the stops and starts, asides, resumptions and suspended endings that make up Horatian satire." In addition, she (1993/2009, 164-165) interprets the fifth sermo as a prolongation of Horace's criticism of Lucilius. I read the poem with a different objective, that is not the literary one. I search for references that support the view that Horace had a functional objective in the first book of Sermones, namely to prove that he was a valuable and trustworthy member of the circle of Maecenas. Thus, I will propose below that the "uncertainties" of the journey presented by him are only one of the indications that the journey in the poem is fictitious. This poetic fiction caused his audience to focus on the hidden meaning of the poem, as they knew very well that Horace never took part in such a voyage. I will discuss all the evidence of the fictional nature of $S .1 .5$ later after completing my review of the narrative of the whole poem.

The next station of the journey, Fundi, gets only a short mention in lines 34-36. In these lines, we come across the first instance in this sermo of Horace's attempts of showing that he has left behind the habits and politics of small provincial towns. We will see this again in lines 51-69 by his treatment of Sarmentus, and in lines 97-103 by ridiculing the superstition of the inhabitants of Gnatia. ${ }^{186}$ He writes in lines 35-36 in a rather condescending manner about Aufidius Luscus, the chief official of the town: insani ridentes praemia scribae,/ praetextam et latum clavum prunaeque vatillum (laughing at the knick-knack of the deranged clerk, the bordered robe, the broad purple stripe and bucket of burning coal). Horace depicts Aufidius as a pompous local dignitary, who put on airs of a senator by wearing the regalia of the senatorial rank. Horace, who had been a scriba himself, reached a much grander position and wants to distance himself from these small-town men. It is quite feasible that Horace chose Aufidius as the name reminds us of the river Aufidus near his home town Venusia. Thus, he does not only distance himself from insignificant Fundi and his chief, but he refers also to his own past in Venusia. ${ }^{187}$

186 Conform Kemp (2010, 73 note 28): "Horace still wants to be seen to be above petty superstition in Satires 1.5, just as he still wants to oppose Stoic extremism with humane Epicurean anthropology in 1.3."

187 Horace's reference to the river Aufidus resembles Virgil's reference to the river Rhenus in Ecl.10, which does not represent the Rhine, but the river Reno in Nothern Italy. In both cases, the poet focuses the thoughts of the reader on the home region of the author. The poet transfers, as it were, some of the argument. For Virgil's use of this functional reference, see Weeda $(2015,79-82)$ and Weeda \& van der Poel (2016). 
After Fundi the party arrives at Formiae, the town of the Mamurra family (Mamurrarum urbe). One Mamurra, a well-known nouveau riche, was from 58 B.C. Julius Caesar's praefectus fabrum (chief engineer) in Gallia, and returned in 55 B.C. to Rome, where he built himself an expensive house on the Caelian Hill. He was notorious for his extravagance, ostentation and his sexual affairs. ${ }^{188}$ Horace returns in line 37 to one of his earlier subjects, that is his loathing of the new rich, presenting Mamurra in a similar way as he did Aufidius in line 34. In both cases, he connects the man with the town - Fundos Aufidio Lusco (line 34) and Mamurrarum urbe (line 37) - suggesting that the parvenus and pretentious dignitaries were not only to be found in Rome, but also in small towns. Fortunately, Horace does not have to suffer their company, as he enjoys the hospitality of people whom he considers his equals, L. Licinius Varro Murena and C. Fonteius Capito; the first a member of a family that brought forth many of the political and social elite, the second a consul in 33 B.C. and ambassador of Marc Antony. Line 38 reads: Murena praebente domum, Capitone culinam (Murena providing shelter and [Fonteius] Capito the catering).

A peak in the journey is the putative meeting with M. Plotius Tucca, L. Varius Rufus and Virgil the next day in Sinuessa, a place on the coast near Naples. Horace says in lines 39-44:
Plotius et Varius Sinuessae Vergiliusque
occurrunt, animae qualis neque candidiores
terra tulit neque quis me sit devinctior alter.
o qui complexus et gaudia quanta fuerunt!
nil ego contulerim iucundo sanus amico.
(for at Sinuessa Plotius, Varius and Virgil come to meet us, no brighter spirits earth bore and nobody is more attached to them than I. O the embracing and how great was our joy! So long as I am in my right mind, there is nothing I would compare with a pleasant friend).

According to Gowers $(2012,197)$, Horace chose cleverly for the Naples region for the supposed meeting with his three poet-friends in order to present his own associations with Philodemus, with whom according to Gowers (2012, 20) "Virgil, Varius and Maecenas were certainly associated." 189 I argue below that the journey, and

188 Catullus writes about Mamurra in CATUL.29.6-9: et ille nunc superbus et superfluens/ perambulabit omnium cubilia/ ut albulus columbus aut Adoneus? (and shall he now, arrogant and with money plentiful, make the rounds of everyone's marriage-bed, like a white cock-pigeon or an Adonis?).

189 Gowers (2012, 197: "they [Plotius, Varius and Virgil] cross his [Horace's] path later than his patron [Maecenas] does, aptly near Naples, centre of the Epicurean sect led by Philodemus (c.110 - c. 35 BC) and Siro with which Varius, Virgil and H.[orace] were associated.” For Horace and Philodemus, see Oberhelman \& Armstrong (1995, 235-236). For the association of Maecenas and Philodemus, see Gowers (2012, 20-21); Kemp (2010, 72-73); Moles (2007, 168). For the allusion to Epicurus in this passage, see Gowers (2012, 197-198). 
consequently the meeting, never took place. Yet, this allusion to his philosophical preference fits in with the general theme of this sermo (and others), that is an account of his views and his person, which demonstrate that he is an acceptable member of the circle of Maecenas, of which Varius and Virgil form also part; they introduced him to Maecenas in 38 B.C. Horace says in line 44 that the three poets are kindred spirits and very special friends.

After an overnight stop in a modest guest house close to Pons Campanus in the Capuan hinterland, the travellers head for Capua where they arrive in good time. Maecenas has the opportunity for a relaxing game, but both Horace and Virgil take to their beds: Horace still suffers from his conjunctivitis (lippis) and Virgil is suffering from indigestion (crudis) (lines 48-49). The next stage takes them not to common inns (cauponas), but to the well furnished villa of L. Cocceius Nerva in Caudium. Here, Horace imagines that a battle of wits (pugnam) between Sarmentus and Messius Cicirrus is staged, which he narrates in lines 51-70. He refers explicitly in lines 53-55 to both men's stock (et quo patre natus uterque). Sarmentus was most likely an Etruscan ex-slave of M. Flavonius, who in 42 B.C. was freed by Maecenas, and promoted to scriba quaestorius. Treggiari $(1969,272)$ mentions the option "that he was a Tuscan, [and that] it is possible that Sarmentus was freeborn and had been wrongfully enslaved. Maecenas may have established his client's right.” He was a comic scurra favoured by Marc Antony, Livia and Augustus, became an eques by purchase, but finished as a typical parasite. ${ }^{190}$ Sarmentus' lineage was similar to that of Horace. Horace will claim in S.1.6.45-46, either autobiographically correct or fabricated, that he was a son of a freedman from provincial Apulia, later a scriba - characteristics which Gowers $(2012,201)$ calls “H.[orace]'s Achilles' heels.” Sarmentus was most likely a freedman himself, became scriba quaestorius, and originated also from a provincial town. A point of particular interest is the difference between the two in the manner of practising their profession: Sarmentus is a scurra, whereas Horace rejects this role emphatically. He does not wish to present himself as a buffoon, as he sees such a character as uneducated and vulgar, not the sort of man he wants to be. Horace wants to position himself as a gentleman commentator. ${ }^{191}$ Thus, Horace, who had a similar social background as Sarmentus, had developed very differently being associated with Maecenas. Messius is unknown and was presumably a local of Oscan stock. The battle of words between Sarmentus and Messius is in keeping with the worst traditions of the comic stage. It does not rise above coarse remarks

190 JUV.5.3 refers to Sarmentus as a despicable parasite. For the passage S.1.5.51-70 and Sarmentus, see Corbett (1986, 66-68); Freudenburg (1993, 203-204; 2001, 55-56); Gowers (2012, 199-200); Oliensis (1998, 28-30). For Sarmentus, see also Gundel (1972b); Treggiari (1969, 271-272). Acc. to Gowers (2012, 200) M. Flavonius, a supporter of Pompey, was killed in the proscriptions after Philippi.

191 For Horace positioning as a gentleman commentator and his rejection of the role asa comic scurra, see my discussion of S.1.3.29-34. 
about physical disfigurements and comparisons to animals intended to insult. In the episode described in lines 51-70, Horace wants to show how well at ease he is within Maecenas' party. According to Oliensis $(1998,29)$ "Horace takes care to locate himself very definitely in the audience, far above the satiric boxing ring." Horace writes in lines 56-57 ridemus (we laugh) when Sarmentus compares Messius to a wild horse (equi te/ esse feri similem dico). This is not an audience's laugh at a funny joke, but a laugh of contempt at such baseness. He preferred to keep himself at a distance of this base humour of the common show demonstrating to Maecenas that such milieu was not his. Horace's final assessment of the evening is also somewhat reserved. He says with an ironical bias in S.1.5.70 prorsus iucunde cenam producimus illam (all in all, we prolonged that dinner pleasantly).

Next day, they travel straight to Beneventum, where the party has a very different experience: a kitchen fire caused by the nervous innkeeper preparing dinner for his distinguished guests. Horace describes in S.1.5.75-76 the confusion when greedy guests (convivas avidos) and frightened slaves (servos timentis) together try to snatch from the dinner what is left and extinguish the fire. The past potential subjunctive of videres in Horace's description suggests that he "again watches the chaos with detachment" (see Gowers, 2012, 205). The route of the party after Beneventum is not clear. Horace tells us that he approaches the Apulian border with relief and gratitude for seeing again his familiar hills and it is the first time in the poem that an appreciation of the landscape shows through his words. S.1.5.77-80 reads:

incipit ex illo montis Apulia notos

ostentare mihi, quos torret Atabulus et quos

numquam erepsemus, nisi nos vicina Trivici

villa recepisset,

(from that point Apulia begins to display to me her familiar hills, which are scorched by the sirocco, and which we would have never climbed had not a villa near Trivicum taken us in) ${ }^{192}$

Horace's extra enjoyment that the villa near to his home region was expected to bring him, the assignation with a local girl, turned out to be a disappointment; the girl did not show up. It may have helped that the next twenty-four miles were done by coach.

It is likely that the party remained on the Via Appia at least as far as Trivicum, if the latter town corresponds correctly to modern Trevico. ${ }^{193}$ If Horace's cryptic mention in lines 86-87 of a small town (oppidulo) where the party was delivered by carriages is taken to refer to Venusia, one last day of travelling by the route of the Via Appia

192 The Atabulus is a burning wind in Apulia, a sirocco.

193 For a detailed discussion of the route at this stage, see Gowers (2003, 76-78; 2012, 205-207), who (Gowers, 2012, 205) states that "it becomes half-clear (at 79 Triuici uilla) that H.[orace] and his companions have continued on the Via Appia at least to that point (if the villa at Trivicum is correctly placed by the Barrington Atlas (p. 45), a few miles off the Via Appia).” For the Barrington Atlas, see Talbert (2000). 
followed. S.1.5.86-87 reads quattuor hinc rapimur viginti et milia raedis,/ mansuri oppidulo quod versu dicere non est (from here, we are hurried away in carriages for twenty-four miles, to stay in a little town which cannot be named in verse). I agree with Gowers (2012, 209), who states that "oppidulo is an underestimate if the town is Venusia," but the latter cannot be fitted into the metre indeed. It could be a bit of Horace's poetic teasing, at which Gowers $(2012,209)$ presumably hints when she says "if $\mathrm{H}$.[orace] is indeed hinting at the prospect of a return to his birthplace, the equally unmetrical Vĕnŭsǐa (see 77-8 nn), a special kind of mock-modesty is in play." Gowers (2012, 208), however, offers also a perhaps rather far-fetched, but still very attractive conjecture that Venusia is meant indeed. In line 84, when Horace falls asleep still longing for the girl who never turned up, he says that he (in the rendering of Gowers) is "keyed up for Venus, bent on sex" (intentum Veneri). This may be an allusion to "heading for Venusia" through what Gowers calls "the provocative echoing of 'Venus'/ 'Venusia' in uestem, uentrem [in 85]; cf. 84 uisu, 86 uiginti, 87 uersu, 88 uenit uilissima, 90 uiator." Gowers' suggestion supports my view that $S .1 .5$ is very well constructed poetic fiction with not only functional references, but also very imaginative literary references. Arguments that Horace praises specifically Venusia may be found in a functional reference in S.1.5.89-91, where he commends the little town for the quality of the bread. Arguments that he also praises the Apulian region in general may be furnished by S.1.9.29-34; the latter passage can be read that Horace was not from Venusia itself, but from somewhere in the region (see the discussion of S.1.9.29-34 in section 2.2.5). S.1.5.89-91 reads:

\footnotetext{
sed panis longe pulcherrimus, ultra

callidus ut soleat umeris portare viator;

nam Canusi lapidosus,

(but the bread [in the little town] is by far the best, so that an experienced traveller is wont to take a load on his shoulders for later; because at Canusium the bread is as hard as stone)
}

If it is accepted that Venusia and the region distinguished themselves selling "by far the best bread," the lines may suggest that he recalls a fond memory from his youth; remembering food that tasted good when young later evokes often warm feelings. But, the mention of panis (bread) can also indicate a functional reference. Horace uses in the whole of his work six times (apart from this one in S.1.5) word-forms of panis, typically in the Sermones and in the Epistulae. In addition to S.1.5.89-91, in five out of the six cases the context, within which he uses the word, is either a description of the bare necessities of food and drink as in S.1.1.47 (see also Gowers, 2012, 73, who refers to S.1.5.90) and in S.1.1.74, or a description of simple living as in S.2.2.17, and in Ep.1.10.11 and Ep.2.1.123. ${ }^{194}$ Thus, I propose that Horace refers in lines 86-90 to

194 For the search of the total number of places where Horace used word-forms of panis, I used Brepols' Library of Latin Texts - Series A, 2016 (http:/www.brepolis.net). S.2.8.68 is the only place 
Venusia and the region, and that he particularly calls attention to his uncomplicated milieu and the naturalness of his upbringing, although he also relates in S.1.6.71-78 that Venusia and environs was totally controlled after the Social War by veterans, whose views and lifestyle were very much in contrast with those of his family (see also section 1.3.2 on Horace's "biography"). This was also the cause of his leaving the town for Rome. Thus, he did not emerge a provincial bumpkin, and he does his utmost to convince Maecenas and his friends that this Venusian background taught him the traditional Roman values

Horace imagines that the supposed party does not continue on the Via Appia arriving the following day in Canusium (modern Canosa) on the Via Minucia. The latter road branched away from the Via Appia at Beneventum an ended by way of Barium (modern Bari) in Brundisium hugging the Adriatic coast. We saw that the text is not clear about the route between Beneventum and Canusium; either via TrivicumAquilonia-Herdoniae, or via Trivicum-Venusia. I prefer to think that Horace described the fictitious latter route, as this gave him the opportunity in his story to dwell on the significance of his Venusia for his education. He may have been deliberately vague about the putative route through his native area. Thus, Venusia was not meant specifically but rather the Apulian region (see above) in order to make the point about the values in the region: in that case S.1.5.77-90 can be paraphrased as that in the Apulian/Lucanian region the traditional Roman values can still be found and that he respects those. But, we will also see that he shows at different places in $S .1 .5$ (in lines 34-36, 51-70, and 97-103) that he has left behind the little-minded habits and politics of small provincial towns.

Horace pictures with regret in line 93 that L.Varius Rufus leaves the putative party in Canusium (flentibus hinc Varius discedit maestus amicis) without telling us the reason of his (unexpected?) departure. In my opinion, both the arrival and the departure of Varius are obviously part of the fictitious nature of the poem. Line 93 should be read in conjunction with lines 39-44 symbolizing the cohesion and devotion to each other of the friends/poets: excessive joy in S.1.5.39-44, when the friends arrived, and deep distress when Varius leaves in S.1.5. 93.

Next, the group travels in poor weather by way of Rubi, and the following day to Barium in good weather. Horace has nothing else to report about the two days than the condition of the road, the weather and that Barium is a fishing town (piscosi). He gives Gnatia (modern Torre Egnázia) more lines, S.1.5.97-103, as the town and her inhabitants present him a good opportunity to show his well-considered philosophical views, which he expects Maecenas may value. Lines 97-103 read:

where the context is not about either basic necessities or simple living, but about the concerns of a host at his dinner party. 


\begin{abstract}
dein Gnatia Lymphis
iratis exstructa dedit risusque iocosque,

dum flamma sine tura liquescere limine sacro

persuadere cupit. credat Iudaeus Apella,

non ego: namque deos didici securum agere aevum,

nec si quid miri faciat natura, deos id

tristis ex alto caeli demittere tecto.

(then Gnatia, which was built when the water-nymphs were angry, made us laugh and gave us merriment when it would have us believe that incense melts on the threshold of the temple without fire. Apella, the Jew, may believe it, not I: for I learned that the gods have a carefree life, and that, if nature accomplishes any marvel, the gods do not send it down from their heavenly home because they are miserable)
\end{abstract}

This story relates to the miracle of Gnatia, the spontaneous blazing of wood on a sacred stone, which causes amusement and hilarity for the sophisticated members of the party. It is the third example in this poem where people in provincial towns are being ridiculed. Horace offers his credentials showing his own "erudition" in lines 101-103 by quoting from de Rerum Natura (LUCR. 5. 82-83). A superstitious Jew and the people of Gnadia may believe in marvels, but Horace "interprets natural phenomena like thunder and lightning in terms of scientific law rather than divine vengeance" (Gowers, 2012, 212). Horace shows again that he does not want to be associated with provincial superstition.

The final line 104 Brundisium longae finis chartaeque viaeque est (Brundisium is both the end of a long story and a long journey) is an abrupt end to the poem. Horace tells us that they arrived in Brundisium indeed, but still does not give us any information about the purpose of the journey. We must do with the cryptic reference in lines 27-33 when Maecenas, Cocceius and Fonteius Capito joined the party in Anxur on the third day. I discussed above the scholarly interpretations of the putative mission of S.1.5, that is that the aim was to repair the Triumvirate. The poem may refer to a diplomatic mission of Maecenas, but we cannot know which one. Horace also studiously avoids to broach the political context of the mission. Nisbet (2007, 10) states that "Horace artfully conceals any political involvement." ${ }^{195}$ If he were in the company of Maecenas, Cocceius and Capito on a major diplomatic mission, he could well have picked up some of its political background, which would have been valuable material for alluding to the importance of his journey, and hence enhance

195 Contrary to DuQuesnay $(1984,40)$, who writes that "Horace is notoriously reticent about the political context and his account is noticeably free of all tensions. That is surely deliberate. [...] The journey, then, which Horace is describing certainly took place, as his contemporaries would be only too well aware.” For Horace's political involvement, see also Lyne (1995, 12-20). I would propose a nuance to Lyne's $(1995,18)$ point, who argues that S.1.5 (and S.2.6) "have a common emphasis, astutely contrived, and they have, I [Lyne] think, a common aim: to advertise a non-politicallyinvolved Horace." I argue that Horace in S.1.5 is not yet politically involved, but is preparing himself actively for such involvement as a political commentator. 
his own prestige. It is obviously possible that he avoided the subject for reasons of confidentiality, but he could have alluded in covert terms to the political importance of this specific mission, that is to say if he had ever been a member of such a mission in reality.

I will now present my suggestions with respect to the historicity of the journey and the function of S.1.5, which I will ground on firstly Horace's description of the route, secondly on the absence of any information about the purpose of the mission, thirdly on the function that he gives to Venusia and the Apulian region, and fourthly on the manner in which he presents himself in the text.

Concerning his description of the route, I divide the route to three parts. I define as the first part the stretch from Rome to Trivicum (approximately 186 miles), reported in lines 1-85. The second part is the voyage of approximately 89 miles in Apulia from Trivicum to Rubi, described in lines 86-95. The third part, the 104-miles stretch from Rubi to Brundisium, is covered in lines 96-104. ${ }^{196}$ Horace takes eighty-five lines recording the first part of the journey, only ten lines on the second part, and nine lines on the third part. We saw that Horace records in the first part of the route in all but one cases (Beneventum) the six stations of an overnight stay and the overnight boat trip through the Pomptine marshes. In addition, he reports episodes of a personal character and provides - in some cases - detailed descriptions of events during the day and evening. For example, he sketches personal experiences such as his stomach trouble due to the poor water quality in lines 7-9, the arrival of Plotius, Varius and Virgil in lines 39-44, the fiasco of his rendezvous with a girl in Trivicum in lines 82-85. Instances of general impressions during the journey are presented, that is the boat journey through the Pomptine marshes in lines 9-23, the arrival of Maecenas, Cocceius and Fonteius Capito in lines 31-32, the battle of words between Sarmentus and Messius Cicirrus in lines 51-70, and the kitchen fire in Beneventum in lines 71-76. In the account of the second part of the journey in Apulia from Trivicum to Rubi, Horace's recording of the overnight stays is scarce. In line 87 he mentions only that the party stayed in a small town (mansuri oppidulo), which he does not identify. I proposed above that it is feasible that the unknown oppidulum is Venusia if they are supposed to have stayed on the Via Appia and turned north beyond Venusia to Canusium. If the town described is indeed Venusia, Horace gives in lines 89-90 the only, though important, personal impression in his report of the second part: his functional reference to the quality of the bread, an allusion to his cultural and social background. There are two more descriptions of interesting personal experiences, that is that apart from the metaphor of the good quality of the bread in Venusia the poet only mentions Varius leaving the party in Canusium, and the problem of the availability of water in Canusium. Although he tells us in line 91 that the party came to Canusium, we are not told whether they spend the night there; however, it is likely they did as they were

196 For a schematic summary of the journey, see Appendix I. 
supposed to have travelled that day some 35 miles. Then, they "travelled to Rubi" (line 94) where they spent the night which can be gathered from line 96: postera tempestas melior (next day's weather was better). The coverage of the last part of the journey, the 104-mile stretch from Rubi to Brundisium is incredibly short. The overnight stays in Barium and Gnatia are not mentioned. The most memorable matters seem to be the weather, the road, and the lack of water from springs in Gnatia in lines 95-98. Horace narrates in lines 98-103 the miracle of the spontaneous blazing of wood on a sacred stone in Gnatia, which prompts a Lucretian reflection. In S.1.5.104, he mentions the supposed arrival at Brundisium in one line.

I conclude that the composition of the narrative shows a remarkable difference in detail and in extent of information about the places visited between on the one hand the first part of the journey and on the other the second and the third. If one were to use S.1.5 as travel-writing, one should not have to travel beyond Trivicum, and even then the information is minimal. For example, one would have expected some information about Aricia in the first part. The description of Apulia in part two is with respect to both the route and the places visited unclear; one town is even indicated only as oppidulum. The report of the third part is a brief list of four towns on the Via Minucia, of which one, Gnatia, attracts a few lines for a derision of her provincialism. I conclude from Horace's description of the journey that the Iter Brundisium in Maecenas' company never took place. Maecenas travelled indeed at several occasions together with other political leaders to Brundisium, but the journey described in S.1.5 is Horace's poetic fiction. Horace obviously knew of previous trips by Maecenas and he used this knowledge as a framework for the present sermo. Further, he knew most likely the part of the Via Appia between Rome and Beneventum reasonably well from his own experience travelling between his home region and Rome. This explains the comparative detail of the description in S.1.5.1-85. The special attention for Venusia in his description of the second part I will discuss below. Further, I suggest that, when he wrote the poem, he had never travelled the stretch from Rubi to Brundisium.

With reference to the second point, that is the absence of any information about the goal of the mission, I argued above that if he had been in the company of Maecenas on a major diplomatic mission, he could well have taken advantage of alluding in covert terms to the political importance of this specific mission, enhancing his own prestige. I conclude from the lack of any information about the context of the mission - apart from the reference to Maecenas and Cocceius in S.1.5.27-29, who were both sent as ambassadors on important business and experienced in bringing together friends who were opposed (missi magnis de rebus uterque/ legati, aversos soliti componere amicos) - that Horace was never a member of such a mission in reality.

Thirdly, Horace pays special attention to Venusia and the Apulian region, although briefly. I also propose that he kept his description of the route of the Apulian part of the "journey" in S.1.5.86-95 deliberately unclear, as he wanted to focus on the quality of his upbringing in Venusia through his metaphor of the quality of the bread. He refers to his milieu in the present sermo as he did in S.1.4 and will do so again in S.1.6, 1.7, 1.9 
and 1.10. The milieu to which he referred in the fourth sermo is his own ancestry: "the father" represents the link between the generations symbolizing the continuity of the traditions. Horace expressed in S.1.4 that he grew up in a family having respect for the old Roman values. In S.1.5, he testifies that he - notwithstanding his allusion to his own estrangement from his past in Venusia in S.1.5.34-36 - recognizes that his family was not the only Venusian or Apulian one holding this respect, the veterans excluded.

The fourth subject, that emerges in the present sermo is the manner in which he presents himself. His aversion of new rich and other upstarts is very evident in lines 34-36 (Fundi, Aufidius Luscus), line 37 (Formiae, Mamurra) and lines 51-70 (Caudium, Sarmentus). This is in great contrast with the appreciation he has of the leaders of the supposed party (lines 27-33) Maecenas, Cocceius and Capito, whom he considers his equals, and the joy of being with his friends (lines 39-44, 93), Plotius, Varius and Virgil. At three occasions, he distances himself from provincial attitudes, in lines 34-36 (Fundi, Aufidius the "praetor"), lines 51-70 (Caudium, base humour of the show of Sarmentus and Cicirrus), and lines 97-103 (Gnatia, the miracle). He intends to be a worthy member of the circle of Maecenas assuring him that he does not want to associate with the nouveau riche and that he also left the provincial milieu behind. He upholds the traditional Roman values handed down to him. Like the closure of S.1.3, this poem also illustrates his contentment with the reception by Maecenas and the members of his circle. This theme returns in S.1.10 and in S.1.9, and I intend to demonstrate in my analysis of the latter poem in section 2.2.5 that $S .1 .5$ and S.1.9 have much in common in structure and theme.

In summary, I interpret S.1.5 as a poem about a fictitious journey. Horace's objective in producing this sermo was, like S.1.1-1.4, to let Maecenas know that he, on grounds of his descent, education and personal development, was well qualified to become a worthwhile and reliable member of Maecenas' circle. In other words, another of his credentials.

Horace continues in Sermo $\mathbf{1 . 6}$ his credentials for Maecenas with a presentation of his views on the significance of one's social background for a political career: low birth should not be an obstacle, and high birth no guarantee, although being wellborn is a recommendation for high office. He also relates more details of his personal background and history and his views about his own future, which he does not envisage as one in politics. S.1.6 contains several themes that are also present in previous sermones, for example his disapproval of the new rich in S.1.1, S.1.2, and S.1.5, the role of Horace's "father" in his education in S.1.4, and his youth in Venusia, his disengagement from provincialism, and the journey from Rome to Venusia in S.1.5, although in the present poem the journey is in the reverse direction. I agree with DuQuesnay's (1984) division of S.1.6 into three main sections: the first section S.1.6.144 on the issue of social mobility and eligibility for high office, the second S.1.6.45-84 (contrary to DuQuesnay's S.1.6.45-88) on his moral credentials and the teaching by 
his milieu and his father, and the third section S.1.6.85-131 with his views on his own future.

Horace raises in S.1.6.1-44 the subject of mobility between social classes, or as Gowers $(2012,215)$ formulates it "he contributes to an age-old debate over the merits of individual worth as opposed to noble pedigree." He broaches in the first forty-five lines of the poem the subject as this issue was particularly pointed in the Late Republic when new classes, who aspired to political influence, came up. ${ }^{197}$ Horace mentions in the opening lines, S.1.6.1-6, Maecenas' ancestry. We saw that he in previous poems, for example in S.1.1 and S.1.5, pointed at the risks of the unbridled ambitions of the new classes, and he will examine in the first section of the sixth sermo Maecenas' views on social mobility against the latter's social background. In S.1.6.1-6 Horace writes:

NON quia, Maecenas, Lydorum quidquid Etruscos

incoluit finis nemo generosior est te,

nec quod avus tibi maternus fuit atque paternus

olim qui magnis legionibus imperitarent,

ut plerique solent, naso suspendis adunco

ignotos, ut me libertino patre natum.

(Although, Maecenas, no one of all the Lydians that have settled in Etruscan lands is of nobler birth than you, and though you had ancestors on your mother's and father's side who once commanded mighty legions, you do not look down your hooked nose, like most men do, at those born of an unknown father, or at me born of a freedman)

The three opening words of S.1.6 non quia, Maecenas recall the first three words of S.1.1 qui fit, Maecenas. The poet refers in the present sermo in a special, almost disrespectful way to Maecenas' ancestry. Although the word generosior in line 2 indicates that Maecenas was of noble birth, the qualification Lydorum quidquid Etruscos/ incoluit finis (of all the Lydians that have settled in Etruscan lands) suggests that the present-day "Etruscan prince" Maecenas originated from a Lydian family that once was new to Italy. I note Gowers' suggestion that Horace did this perhaps tonguein-cheek: she $(2012,219)$ states that he “between the lines pokes fun at Maecenas' pet hobby, genealogy, and his pretensions to royal ancestry, pointing out that his patron, like himself, is technically an outsider in Rome.” The fact that Asian immigrants were often seen as equivalent to imported slaves and that Maecenas himself came from provincial Italy implied that his background was not very distinguished. DuQuesnay $(1984,44)$ observes "that he was not a Roman nobilis. In view both of this and of the current political climate it is worth stressing that his ancestors are for once not called

197 For general commentary on S.1.6, see Anderson (1982, 120-123); Brown (2007,150-165); DuQuesnay (1984, 43-52); Gowers (2012, 214-250); Rudd (2007, 36-53); Shackleton Bailey (1982, 14-20). For Horace and social mobility, see Armstrong (1986); Gowers (2012, 215); Lefèvre (1993, 98-99). For the position of freedmen and their sons in general, see Treggiari (1969); Wiseman (1971, 110-116). For Horace and the role of his father in S.1.6, see Harrison (1965); Lefèvre (1993, 98-100); Schlegel (2000, 108-117). 
reges [kings] but olim qui magnis legionibus imperitarent (who once commanded mighty legions) ([line] 4). This description matches the claims of the Roman nobilitas precisely in the terms of their own aristocratic code of values.” Thus, Maecenas fitted well in the top of Roman society. ${ }^{198}$ MacKay $(1942,80)$ was unable to find in ancient testimonies any conclusive evidence about Maecenas' distinguished descent. He concluded "that Maecenas' family was socially little if at all above the families of other upstarts who, as Syme [2002, 129] points out in his Roman Revolution, formed the bulk of Octavian's supporters." Wiseman $(1971,52)$ observes that the contemporary leaders of Roman society grew up in the provinces, and that Roman society was dominated by "Maecenas of Arretium, the obscurely born Vipsanius Agrippa, and the princeps himself from a small town in Latium." Although Horace mentions in lines 3-4 that Maecenas' ancestors on his mother's and father's side once commanded mighty legions, this may refer to nothing more elevated than their equestrian status. Syme $(2002,129)$ states as a fact that Maecenas "was of regal stock, deriving his descent on the maternal side from the Cilnii, a house that held dynastic power in the city of Arretium from the beginning." Simpson (1996), however, concludes that the contemporary sources do not confirm that Maecenas' mother was a member of the Cilnius family. Maecenas' claim to regal descent remains a matter of speculation: it is presumably the result of his father's marriage above his station to a Cilnius girl. ${ }^{199}$ Maecenas may have overstated his social position by posing of nobler birth than he was. This was perhaps the real cause of his genealogical interest. Although there is a difference in the social background of Maecenas' family and that of Horace's family, the first being of equestrian status and the second the son of a freedman, the latter saw his own social position as equivalent to that of Maecenas. ${ }^{200}$ Horace claims in S.1.6.48 that he also commanded a Roman legion (quod mihi pareret legio Romana tribuno). Further, it is held that Brutus elevated Horace to the rank of eques. ${ }^{201} \mathrm{I}$ suggest that what Horace says in lines 5-6 to Maecenas is a compliment, when he declares that the latter does not look down upon him, the son of a freedman. Horace sees himself indeed socially equal to Maecenas, but he also recognizes that Maecenas has an advantage over him. It is likely that the man from Arretium was born into a family that one or two generations before Horace's attained some form of elevated social standing. Yet, Maecenas did not forget his roots and reveals an enlightened view on social mobility. It is likely that Horace would not have made the point that Maecenas and he are both upstarts if he did not have irrefutable evidence concerning

198 For Maecenas' supposed Lydian origin and descent from Etruscan kings, see Gowers (2003, 7980; 2012, 216; 219-220); MacKay (1942, 80); Shackleton Bailey (1982, 17); Simpson (1996). For Lydian immigration to Etruria, see Scullard (1967, 34-57).

199 For the Cilnii, see Scullard $(1967,167)$.

200 Conform Shackleton Bailey (1982, 17). See also Gowers (2012, 219). For Horace the son of a freedman, see my discussion of S.1.6.71-75 in section 1.3.2; Gowers (2012, 222; 236-237).

201 Armstrong (2010, 17-18); Gowers (2012, 219; 232); Ross Taylor (1925). 
Maecenas' past. He makes his point in the style of a gentleman jester, the man who knows when to make a sensitive point. He returns to this style later in the poem in lines 97-111 when he compares in a critical tone his own ambition and his preferred future lifestyle with the present one of Maecenas.

S.1.6 is the next instalment in Horace's series of credentials, in which he presents himself as a reliable member of Maecenas circle sharing the latter's political convictions. Having concluded that Maecenas and he are social equals, Horace recognizes that Maecenas shoulders greater political responsibility than he. In lines 7-8 Horace observes approvingly that Maecenas is generous in his judgement of peoples' worth. S.1.6.7-8 reads: cum referre negas quali sit quisque parente/ natus, dum ingenuus, persuades hoc tibi vere (when you [Maecenas] say it does not matter what sort of parent everyone has, as long as he is free-born, you'd be right in this conviction). The poet repeats the compliment in S.1.6.51-52 and S.1.6.63-64. I propose that these two lines ought to be read in conjunction with the previous two, particularly with the words ut plerique solent in line 5. If these words are also seen as relevant to S.1.6.7-8, Horace states that most members of Maecenas' social rank have a prejudiced, if not hostile, view of social mobility. Many members of the elite saw the new men as a threat to their own traditional place in society arguing that for example freedmen's sons were not capable of holding high office because they lacked either the proper education, or didn't have the right experience or financial means. Horace resented indeed the new rich who exhibited an unrelenting ambition for office with the rewards belonging to it, but he accepted that men who aspired for office should be judged on their individual merits. ${ }^{202}$ Social mobility and its pros and cons is the theme of the next section.

Horace is in the first main section, S.1.6.7-44, concerned with social mobility, both in the distant past and in his own days. In S.1.6.9-17, he presents instances of social mobility going back to the days of Servius Tullius, king of Rome from 578-535 B.C., who is "said to have been born of a slave mother and an unknown father" (see Gowers, 2012, 223). Lines 9-11 describe that before Servius became king many men with insignificant ancestry lived often honourable lives and were enriched with high office (ante potestatem Tulli atque ignobile regnum/ multos saepe viros nullis maioribus ortos/ et vixisse probos, amplis et honoribus auctos). But after times of opportunities for many, Servius is known to have curtailed voting rights by granting those according to wealth. Next, Horace describes "the black sheep" Laevinus, a member of the old aristocratic gens Valeria, of whom we only know from S.1.6.12-13 that he descended from that Valerius unde superbus/ Tarquinius regno pulsus fugit (through whom Tarquin the Proud was driven from his tyranny and went into exile) in

202 Contra the Loeb edition, where lines 1-6 are separated from lines 7-44 by a new paragraph. For persuades hoc tibi vere I follow the rendering of Gowers (2012, 223). For the criteria for eligibility, see DuQuesnay (1984, 45-49), and my discussion of S.1.6.41-42. 
509 B.C. ${ }^{203}$ Contrary to Servius Tullius, Laevinus "is of high birth failing to guarantee merit" (Brown, 2007, 153), who would still turn out to be a loser, if he were to be judged by people known for their regard for aristocracy. In lines 12-17, Horace records the miserable quality of the process of determining the eligibility for political functions.
contra Laevinum, Valeri genus, unde superbus
Tarquinius regno pulsus fugit, unius assis
non umquam pretio pluris licuisse, notante
iudice quo nosti populo, qui stultus honores
saepe dat indignis et famae servit ineptus,
qui stupet in titulis et imaginibus.
(that Laevinus, on the other hand, who descended from that Valerius through whom Tarquin the Proud was driven from his tyranny and went into exile, was never thought worth tuppence, given a black mark by the judge you know: by the people, which often as a fool give office to the undeserving and are stupidly enslaved to fame and dazzled by titles of honor and ancestral images) $)^{204}$

Horace had no good word to say for the process, which he described as fickle and unreliable. His final conclusion will be that the process is so poor that he does not want to be part of it.

The climax of this short historical excursion is in lines 17-18, when he poses the rhetoric question quid oportet/ nos facere a vulgo longe longeque remotos? (what ought we to do, we who are far, far disconnected from the crowd?). I interpret these words as Horace saying: we, Maecenas and I, intelligent and reasonable men, should certainly continue judging people on their own merits. In addition, S.1.6.17-18 looks forward to S.1.6.19-22, and the six lines should be read as one statement by Horace, that is that Horace wants to stay out of practical politics. Gowers $(2012,225)$ states that lines 17-18 can also be interpreted as "what am I H.[orace] to do, who am so far removed from the common people?” a rare use of the "royal we” by Horace. ${ }^{205}$ She $(2012,225-226)$ argues that

203 For Laevinus, see Deißmann - Merten (1975): "P.V.[alerius] Laevinus, bei Hor.s.1,6,12 erwähnter Senator, der es auf grund der Abneigung des Volkes gegen ihn trotz vornehmer Herkunft und wiederholter Bewerbung nur bis zur Quaestur brachte” (P. Valerius Laevinus, mentioned as senator at HOR.S.1.6.12, who, because of the aversion to him by the people, only succeeded in becoming quaestor, in spite of his distinguished descent and repeatedly standing for a [more prestigious] office). Brown (2007, 153): "about the degenerate descendant [Laevinus] nothing else is known; Porphyrio's allusion to a P. Valerius Laevinus who failed because of his dissolute character to rise above the quaestorship may be sheer guess-work.” Gowers (2012, 224-225); Rudd (2007, 49; 138). All that Rudd (2007, 138) says about Laevinus in the category Dead people to whom Horace refers is: "passing quickly over [...] the black sheep Laevinus (1.6.12)."

204 The rendering of unius assis non umquam pretio pluris licuisse is by Brown $(2007,63)$.

205 For the discussion of lines 17-18, see Gowers (2012, 225-227). 
the implied answer [to the question] 'Stay out of politics altogether', now leads easily to the next section, but the link with the opening passage on Maecenas' liberality is consequently weaker (H.[orace']s response would now arise solely from the attitude of the people). In either interpretation, the logic is stained.

When we read lines 17-18 in context with lines 20-22, Horace's intention becomes clear. S.1.6.20-22 reads:

\author{
censorque moveret \\ Appius, ingenuo si non essem patre natus: \\ vel merito, quoniam in propria non pelle quiessem \\ (and an Appius as a censor would strike me off the senatorial roll, unless I were the son of a free- \\ born father: deservedly indeed, as it would not make me feel good) ${ }^{206}$
}

Firstly, he would not qualify to become a senator anyway on grounds of Appius' action as recorded in S.1.6.20-21. The censor Appius Claudius Pulcher removed all sons of freedmen from the Senate in 50 B.C., after many of them had been admitted to the Senate in the previous decenniads. ${ }^{207}$ Horace, the son of a freedman, refers in these lines to the impossibility of him being a member of the Senate, as the rule was still put into practice when he wrote S.1.6, ten to fifteen years later on. Secondly, he makes in line 22 a personal point, that is that he would not wish to aspire to a political career, as he would not feel good being a politician. He would not want to be involved in a selection process that befell Laevinus as recorded in S.1.6.12-17. ${ }^{208}$

Thus, S.1.6.20-22 contains a very significant message from Horace to Maecenas, namely that his interest in political issues is not caused by political ambition. My interpretation differs essentially from that of Gowers (2012, 227). She argues that S.1.6.22 "produces a sudden and unexpected twist. H.[orace] concludes that he would be deservedly punished for political ambition, since Epicurean quietism is the best policy for those, like himself, of humble birth."209 Quietism may play a part, but I do not see "the sudden and unexpected twist." Horace has no ambition to become a politician, but he prepares himself in the first book of Sermones for his future role of

206 Acc. to Lewis \& Short $(1955,1326)$ in propria pelle quiescere is a phrase meaning "to be content with one's own state or condition.” Thus, I translate here the rather pompous "I would not be content with my own state" as "it would not make me feel good." The expression is an allusion to a wellknown fable by Aesop of the ass in a lion's skin. See also Gowers (2012, 227).

207 For the history of selection for the Senate, see Armstrong (1986, 267-277); Gowers (2012, 215; 224); Rudd (2007, 36-40); Treggiari (1969, 229-236); Wiseman (1971). For the action of Appius, see Gowers (2012, 215; 226); Treggiari (1969, 60-61); Williams (1995, 310; 2009, 152-153).

208 Contrary to Treggiari $(1969,61)$, who states that Horace did not want to go into politics because "he would be going out of his proper metier. The feeling that politics were the rightful business of the rich and leisured nobiles was as strong in Rome as most of the laws."

209 Italics in the quote are mine. 
political commentator: the statement in line 22 is in entire agreement with the attitude he reveals already in for example S.1.3.29-34 and in the final lines of S.1.6.

Next, Horace pays in S.1.6.23-44 attention to the endeavours of men of his own days to gain office. We saw above in the case of Laevinus (lines 12-14) that both Maecenas and Horace endorsed the view that the nobiles on grounds of inherited worth (virtus) through birth have a valid claim to be selected for high public office, provided that they are not disqualified by lack of individual worth. If this were the case, it would be preferable to elect worthy free-born homines novi (new men) instead of unworthy aristocrats. ${ }^{210}$ In lines $23-24$, he gives his view on what often motivates both the unknown (ignotos) and the well-born (generosis), namely not the desire to serve the welfare of the state but to serve Gloria: passion for glory, ambition. He imagines ambition on her chariot dragging her victims. S.1.6.23-24 reads: sed fulgente trahit constrictos Gloria curru/ non minus ignotos generosis (but Gloria drags along chained to her glittering chariot the unknown no less than the well-born). Horace rejects emphatically in lines 23-24 the pursuit of ambition often seen with men who strive to gain high office and who seek to further their own, financial, interests.

Horace then gives some examples as to how people can go wrong when they yield to the temptations of ambition introducing in the same line (24) his first example of the ignotos, a man called Tillius, whom he condemns in lines 24-25 for his political ambition: quo tibi, Tilli,/ sumere depositum clavum fierique tribuno? (what good would it bring you, Tillius, to assume the broad stripe that you had to give up and become a tribune?). I interpret depositum clavum as meaning that the unknown Tillius was one of the freedmen's sons who were admitted to the senate. These men, however, were for reasons of political expediency expelled again, either by Appius or later in the early 30s B.C. Gowers $(2012,228)$ offers the same interpretation of line 25 when she says "next to sumere, depositum suggests disquieting flux in the senate's constitution." Gowers' and my reading of depositum clavum are important for establishing the likely identity of Tillius. For example, according to Toher (2005, 186-189) Tillius is modelled after L. Tillius Cimber, who in his view put aside as a young man voluntarily the senatorial tunic.

Horace mentions in S.1.6.26 the result of Tillius' ambition: invidia (envy), which he would not have suffered if he had stayed privato (without office). The poet depicts in the following lines 27-29 the resentment that freedmen's sons have to suffer when they are successful in public office. He puts his condemnation quite plainly in those lines when he qualifies as crazy someone, who attires himself as a senator, but shows also his annoyance at the antagonistic approach towards low-born men who succeed in political office. S.1.6.27-29 reads:

210 For a comprehensive exposé of the socio-political context of the eligibility for high political office in the Late Republic/Early Empire, see DuQuesnay (1984, 44-48). 
nam ut quisque insanus nigris medium impediit crus

pellibus et latum demisit pectore clavum,

audit continuo 'quis homo hic est? quo patre natus?'

(for as soon as one is crazy enough to encircle his legs up to the middle with the black leather strings and let the broad stripe hang down his chest, he immediately hears "Who is this man? Who was his father?")

It should be noted that Horace makes pellibus in line 28 echo pelle in line 22: in both cases the high office causes an impediment for his preferred way of life.

Tillius' identity has given rise to much discussion in the scholarly literature. Firstly, some see the figure as poetic fiction, representing Horace himself. Secondly, others identify him either as Horace's contemporary L. Tillius Cimber, Julius Caesar's assassin, or (for example Porphyrio) as the latter's brother. A third option is, in the words of Gowers (2012, 228), that “Tillius might have been a freedman's son who incurred hostility when he attained senatorial rank."211

The poet gives some powerful clues for the identity of Tillius in the first main section (S.1.6.7-44), such as his functional reference in line 6 to his own background as a freedman's son, in lines 9-11 to men of humble origin who attained high office, and in lines 23-24 to Gloria who also has the unknown chained to her evil chariot. Within a context of the opportunities and risks for freedmen's sons, one would expect Tillius to be one. That is not to say that I read Tillius representing Horace, although S.1.6 is indeed also a poem in which Horace writes about himself denying any personal ambition for a political career. However, an interpretation of Tillius' identity as that of Horace does not agree with the broad context of the poem as a whole. He describes in S.1.6 the positions of several social classes in the political spectrum in general, and he presents the process of gaining political office by unknown men and the dangers of unfettered ambition, of whom Tillius is just one example of many. Concerning his own position, Horace gives in this section his arguments to stay away from the political business, as it would not make him feel good, as he said in line 22: quoniam in propria non pelle quiessem.

I also suggest that Horace did not intend to use the name of Tillius in order to refer to the hated L. Tillius Cimber or his brother. Toher (2005) argues that Julius Caesar's assassin is the Tillius of S.1.6. One of Toher's (2005, 186-187) main arguments is that "the phrase depositum clavum in Horace [S.1.6.25] could simply mean that at some

211 For Tillius, see Münzer (1942). For an overview of the different options of the identity of Tillius, see Toher (2005) and Gowers (2012, 227-228). For Tillius as a hypothetical version of Horace, see Armstrong (1986, 271-273): “Tillius is Horace” (Armstrong, 1986, 272). For the choice of L. Tillius Cimber, the assassin, see Toher (2005). For Tillius as the latter's brother, see Armstrong (1986, 271272), DuQuesnay (1984, 47), Ross Taylor (1925, 169), and Wiseman (1971, 266) who reject this option; Wiseman states "the scholiast's note looks like guesswork, and is rightly rejected by Kiessling-Heinze [1959, 112-113] (on 6.25) and Fraenkel (Horace [2002,] 102 n.6).” For the third option of Tillius as an unidentified freedman's son who became a senator, see Armstrong (1986, 272); DuQuesnay (1984, 47). 
point early on Tillius, like Ovid, had lost interest in a senatorial career and so as a young man put aside the tunic with the latus clavus." This habit was not uncommon among the sons of the senatorial class. He (2005, 188-189) also states that Tillius Cimber may have survived Philippi, was pardoned and "chose to take up again the latus clavus and the path of ambitio, gained high office, but found only defeat and infamy as the reward for his cupiditas gloriae." In my view, it is significant that no independent contemporary testimony of the assassin Tillius' second career as tribunus plebis and praetor exists (see also Toher, 2005, notes 17 and 19). The reference of Horace in line 25 to the clavus does not infer that he modelled the Tillius of S.1.6 after Tillius Cimber. Overt allusion to Julius Caesar's assassin does not fit comfortably in a sermo that is addressed to Maecenas, confidant of Octavian, Julius Caesar's adopted son.

The third option comes close to my view on the identity of Tillius. My reading of lines 24-25 fits much better within the context of the poem and of S.1, in which Horace offers his political credentials to Maecenas claiming that he will be a worthwhile member of Maecenas' circle. I concur with much of what DuQuesnay $(1984,47)$ writes:

The rest of this first main section [S.1.6.7-44] focuses on Tillius. His identity is unfortunately not certain. He is accused [by Horace] of being the son of a freedman (1.6.38-41). He had been expelled from the senate (1.6.25 with Porphyrio's comment: nam pulsus ante senatu fuerat [because he was previously expelled from the senate]. The context would naturally suggest that he had been expelled by Appius Claudius. He later re-entered the senate and became a tribune. It is subsequently revealed that he also became a praetor (1.6.108). Porphyrio says simply that he was readmitted to the senate post Caesarem occisum [after Julius Caesar's murder]).

I see Tillius in S.1.6.24 indeed as an ambitious freedman's son, who had an erratic political career, but remains otherwise unidentified. In other words, the Tillius of S.1.6 may well be Horace's fiction, who was not modelled after a historical person. Horace made him an embodiment of political ambition leading to his senatorial rank followed by his removal, with other attributes added, namely a man of humble descent or a freedman's son symbolizing in S.1.6.107 the bad habits of the ambitious new men. These characteristics match precisely the subjects on which Horace focuses in S.1.6.7-44.

One unidentified Barrus is introduced in lines 30-33, whom Horace describes as a vain man, perhaps a well-known society figure, a handsome boy type, who shows off his attractiveness to the girls in the hope that he can win them over. Horace describes this folly as an embarrassing form of exhibitionism. He calls it an illness (morbo), and regards it presumably as a disorder of the mind. He makes in lines 34-37 the point that he who puts himself up for a public function is prone to lose his dignity and privacy just like Barrus who throws away his honour. S.1.6.34-37 reads:

sic qui promittit civis, urbem sibi curae,

imperium fore et Italiam, delubra deorum, 
quo patre sit natus, num ignota matre inhonestus,

omnis mortalis curare et quaerere cogit.

(so he who assures to look after the citizens, the city, the empire, Italy and the sanctuaries of the gods forces the whole world to trouble themselves to ask who his father is or whether he is unrespectable through an unknown mother)

Horace declares again, this time implicitly, that he does not want to be part of the group of men holding public office losing his privacy and independence.

In the lines that follow, Horace stages a mock conversation about the political careers of three freedmen's sons. A free-born points out to them the grave responsibilities of Roman magistrates. ${ }^{212}$ The poet voices the prejudice of the established political elite that the new men are not qualified to carry out their duties properly. The free-born says in S.1.6.38-39 'tune, Syri, Damae, aut Dionysi filius, audes/ deicere de saxo civis aut tradere Cadmo?' ('Do you have the nerve, you the son of Syrus, Dama or Dionysius to throw citizens from the rock or to hand them over to Cadmus?"). Although the three names are common slave-names, I concur with Gowers $(2012,229)$ that freedmen's sons are meant. ${ }^{213}$ The poet describes the right to inflict the deathpenalty by public execution, that was reserved to the magistrate, in a very imaginative way: to have criminals flung off the Tarpeian rock or strangled in jail by Cadmus, the public executioner. Gowers $(2012,230)$ makes an interesting point on line 39, when she observes that

The two punishments are described in language that connects them with the ups and downs of the socio-political situation in general: deicere de saxo suggests the physical equivalent of political humiliation (cf. 18 remotos, 25 depositum, 28 demisit); tradere Cadmo (Cadmus, judging by his pretentious mythological name, is an ex-slave himself) offers a cruel parody of patronage and recommendation, tradere supplying the crudely operative verb missing from the account of Varius and Virgil's introduction of H.[orace] to Maecenas at 54-5 but uttered by the pest at 9.47 hunc hominem uelles si tradere.

The scene expresses the resentment of free-born men at the promotion of ex-slaves or of freedmen's sons to high public offices. This feeling is also apparent from the use of the word civis in S.1.6.39. In the words of Gowers (2012, 230): "ciues [= civis] expresses outrage; genuine citizens are in the power of upstarts."

Two upstarts, the son of a freedman and the freedman Novius, enter in S.1.6.40-41. Horace makes clear that the son of a freedman speaks disdainfully about the freedman Novius, as the former says about the latter in line 41: 'namque est ille, pater quod erat meus.' (for he [Novius] is only what my father was [freedman]). The social distinction between a freedman and the son of a freedman is obviously that the former was

212 For the opportunities of the sons of freedmen and of their fathers, see Treggiari (1969, 229-236). 213 Contrary to Brown (2007, 155), and Rudd (2007, 146; 191; 229; 234). Apart from this line, Rudd discusses the slave Dama in S.2.5.18, 101 and S.2.7.54, where he is depicted in very different contexts. 
once a slave and the latter is possibly "free-born." Treggiari (1969, 62-63) concludes that there is much evidence that sons of freedmen were admitted to the Senate or held magistracies: "Moreover, there is no conclusive proof that libertini [freedmen] themselves were debarred by law from holding office, but we find no mention of any certain freedmen holding office: the lowest legitimate magistrates mentioned are their sons. Mos [custom], which was strong against the sons of freedmen, was stronger still against freedmen themselves.” The obstacles to freedmen, and to a lesser degree their sons, were social, cultural, educational and a lack of financial means. Horace's son of a freedman achieved the desired public position, and readily assumed the airs of the free-born showing his resentment of Novius' position, one of the freedmen who were promoted to the Senate by Julius Caesar in 45 B.C. and by the Triumvirs in 39 B.C. ${ }^{214}$ He begrudges in line 40 his colleague Novius' seat in the theatre sitting only one row behind him: 'at Novius collega gradu post me sedet uno.' The new generation of freedmen has come too near to "the old," the sons of freedmen of the previous generation. Horace shows the relativity of this form of new class-consciousness through what the big-headed son adds to his outburst against the pretensions of the freedmen in S.1.6.41-44:

'hoc tibi Paulus

et Messalla videris? at hic, si plaustra ducenta

concurrantque foro tria funera, magna sonabit

cornua quod vincatque tubas: saltem tenet hoc nos.'

("do you therefore think that you are a Paullus or a Messalla? And he [Novius], if two hundred wagons and three great funerals clashed in the Forum, will make a noise enough to drown out the horns and trumpets: by this means at least he will have a hold on us") $)^{215}$

The poet states in S.1.6.41-42 that the freedman Novius will never match the social standing of the aristocracy. Paulus refers to Aemilius Paullus Lepidus and Messalla to Valerius Messalla Corvinus. I agree with DuQuesnay’s $(1984,45-46)$ point that the mention of the latter two aristocrats has a special significance. At the time, those men were two of the few supporters of Octavian to be found within the old aristocracy. Most of them supported Marc Antony, or even worse, Sextus Pompey. Octavian needed the support of the Senate which traditionally was dominated by the nobiles. Hence, Maecenas, and with him Horace, supported the claims of the old aristocracy that birth was an important qualification for high office, though the most important criterion for eligibility is that the men who aspired for office should be judged on

214 For the position of freedmen at the Late Republic/Early Empire, see Gowers (2012, 230); DuQuesnay (1984, 44); Treggiari (1969).

215 Although the OCT gives funera, magna sonabit, I follow Gowers (2012, 231) that magna agrees with funera. I have also followed her rendering of saltem tenet hoc nos. 
their individual worth, or lack of it, as we saw in S.1.6.7-8 and S.1.6.12-18 (the Laevinus story). DuQuesnay $(1984,46)$ summarizes Maecenas' views as follows:

The promotion to high office of noui homines [new men] is entirely justified by their uirtus [worth]. Yet birth also is important: to hold public office, a man should be at least ingenuus ingenuo patre natus [free-born with a free-born father], while the Laevinus story suggests that a nobilis [aristocrat] may be disqualified from taking up his birthright by lack of uirtus [worth]. This attitude must have given hope and encouragement to both noui and to those nobiles wanting to return to Italy after the war with Sextus or those who had returned after the treaty of Misenum in 39 .

It seems to me, however, that DuQuesnay undervalues the qualification on grounds of high birth as the reference to Paulus and Messalla in lines 41-42 suggests. A member of the aristocracy with the right virtus had a better chance of becoming a senator than a free-born son of a freedman. An ambitious freedman like Novius will never make it, and Horace demonstrates what remains for men like Novius by means of the comic scene of a traffic jam at the Forum. Novius' loud voice alludes to the likely occupation that is available for freedmen: a praeco, an auctioneer or a public crier. The latter occupation returns in S.1.6.86-87 as a possible career for Horace in his father's opinion.

In summary, Horace presents in the section S.1.6.1-44 his views on social mobility and eligibility for high office: give talent a fair chance, but the real work will go to the traditional upper class, as birth remains the determining factor. These views are according to DuQuesnay $(1984,44)$ "as least as much those of Maecenas as of Horace." I interpret the section as another part of his efforts to demonstrate to Maecenas that they think alike in political issues. Further, he gives in this section his arguments to stay away from the political business, as a career in politics would not make him feel good.

The next section, S.1.6.45-84, starts with the words nunc at me redeo (now to return to myself). $S \cdot 1 \cdot 6 \cdot 45-52$ reads:

nunc at me redeo libertino patre natum, quem rodunt omnes libertino patre natum, nunc quia sim tibi, Maecenas, convictor; at olim quod mihi pareret legio Romana tribuno. dissimile hoc illi est; quia non, ut forsit honorem iure mihi invideat quivis, ita te quoque amicum, praesertim cautum dignos adsumere, prava ambitione procul.

(now to return to myself, son of a freedman father, whom all backbite as son of a freedman father, nowadays because I am your companion, Maecenas; but in the past because as a tribune a Roman legion obeyed me. The two are different; because it would not be right that anyone envies 
me also your friendship, as it perhaps might be right to envy me the post [of tribune], especially when you are careful to adopt deserving men who shun improper ambition) $)^{216}$

Some of the important themes of the previous section S.1.6.1-44 come to light in a nutshell in these eight lines. In lines 45 and 46, he mentions his status of son of a freedman. The first point that he raises is perhaps the one that troubles him most, that is his own status as son of a freedman (libertino patre natum). The second point is his own social mobility which he describes in lines 47 and 50, his friendship with Maecenas. In lines 48 and 49 he mentions his serious miscalculation when he was a tribune in Brutus' army and fighting at the wrong side at Philippi. He also admits in lines 49 and 50 that people, who resent his post of tribune in the past in Brutus' army and who see the advancement of his career and social status after that, may have a point. Those people may not ignore his former choice for the anti-Caesarian party and may not accept Maecenas' generosity, although he was most likely elevated to the status of eques in 43 or 42 B.C., and he bought the position of scriba quaestorius probably in 41 B.C., both many years before he met Maecenas. ${ }^{217}$ Finally, Horace recounts in lines 51 and 52 Maecenas' good judgement accepting within the circle around him men who shun improper ambition, those who do not pursue high political office and are motivated by avaritia, ambitio and luxuria (greediness, ambition and extravagance), as he saw with many of the new rich. Many new men also succeeded to become new rich, of whom many used their wealth attempting to buy political office. This was a major issue for Horace, and he condemned in every sermo of the first book (except in S.1.8) those vices, which he observes in all layers of the population. He saw those vices as a threat to the traditional structure of Roman society. The number of new rich grew particularly amongst the bankers, moneylenders, merchants and manufacturers in the provinces and in Italy, and amongst the military and the freedmen. Military men made their fortune in the areas where they settled after completing their time of service, or enriched themselves by the sale of booty they stole in the wars overseas or confiscated in the proscriptions (S.1.2). Others extracted as tax officials large amounts of money from local businessmen in the provinces (S.1.7). Horace condemned the lifestyle of the nouveau riche, who showed his wealth in extravagant (particularly luxurious building) enterprises. For example, he relates the building of luxurious villas not only at the end of S.1.2 (section 2.2.1), but also in Carm.2.15 and Carm.2.18.

Next, Horace narrates his introduction to Maecenas stating in lines 54-55 nulla etenim mihi te fors obtulit: optimus olim/Vergilius, post hunc Varius, dixere quid essem. (since it was not chance that brought you [Maecenas] in my path; some time ago

216 The rendering of praesertim cautum dignos adsumere, prava/ ambitione procul is close to that of Gowers (2012, 232).

217 For Horace's social status in S.1.6, see Armstrong (1986, 267-277), and sections 1.1 and 1.3. For his equestrian career, see Armstrong (1986, 255-263); Ross Taylor (1925). For his career as scriba, see Armstrong (1986, 263-267). 
the excellent Virgil and after him Varius told you what I was). It is notable that in Horace's view of the meeting, Maecenas came in his path and not the reverse: another indication that he sees himself as socially equal to Maecenas. After the preparatory work by his two friends Horace was introduced to Maecenas in line 56. Horace depicts both Maecenas and himself as two reserved and uncommunicative men at their first meeting. Horace writes about himself in lines 56-57 that ut veni coram, singultim pauca locutus,/ infans namque pudor prohibebat plura profari (when I came face to face with you, I sobbingly spoke a few words, because speechless embarrassment prevented me saying more). After Horace has told Maecenas in lines 58-61 that he was not the son of a famous father (non ego me claro natum patre) and that he did not own country estates that needed a horse to get round (non ego circum/ me Satureiano vectari rura caballo), Maecenas reply was brief, as was his way (respondes, ut tuus est mos,/pauca). Whether this scene represents what actually happened at their first meeting is not particularly relevant. I do not interpret these lines - and indeed the whole of S.1 - as simply autobiographical, but as a combination of autobiography and poetic fiction. The point is that Horace does not present himself as one of the new rich aspiring for the friendship of Maecenas. Both are depicted as recognizing the cultivated manners of the other, and they would not need many words to understand each other. Contrary to the new rich, Horace is embarrassed: presumably not by his social status, but by his association with Brutus' party in the past. I differ from Armstrong (1986, 267), who argues "that the occasion of the poem is Maecenas' asking Horace whether he would like to leave his scribeship and be supported for the first rank of the senate, the quaestorship." ${ }^{218}$ I suggest that he wrote S.1.6 as one of his credentials in order to be accepted as an associate who is socially and politically acceptable for Maecenas.

In the poem we find three times the words libertino patre natum (a freedman's son): in the opening address to Maecenas (line 6), and in the passage about his first meeting with Maecenas (lines 45 and 46). Later in the same passage there is a slight modification of these words when he says in line 58: non ego me claro natum patre (that he was not the son of a famous father). I interpret the emphatic reiteration of this point that the poet tells us that he, a son of a freedman himself, endeavours to advance and to be found acceptable to Maecenas and the circle around him. That is the poet's way of social mobility. He exaggerates the point by making it three times, and in so doing hopes to give it more impact. I argued before in section 1.1 that my interpretation differs substantially from that of Freudenburg, who states that Horace's words about his putative humble origins mean that the poet tells Maecenas that the latter needed "a truth-telling philosopher" and that he, Horace, was such a man. Although Horace's occasional references to philosophical dogmas were basic

218 For Horace's first meeting with Maecenas, see Armstrong (1986, 259-262); Gowers (2003, 78), who sees $S$.1.6. as "the most obviously autobiographical poem in the book." 
to his ethical socio-political views, he did not promote himself as an adviser on philosophical doctrines. Freudenburg $(2010,281)$ holds the view

that Horace patterns his introduction to Maecenas after that of Bion of Borysthenes to Antigonus Gonatas. As Bion himself tells it in his famous letter to Antigonus, the first words out of his mouth when he came into the king's presence were "I am the son of a freed slave" [as described in Diogenes Laertius 4, 46 (Hicks (Loeb), 1959, 424-425)] [...], and that phrase is repeated as the mantra of his letter to Antigonus, just as it is for Horace in his address to Maecenas in Satires 1.6.

Thus, Freudenburg (2010, 281-282) sees the literary allusion to Bion as an expression

that helps us structure the speaker's [Horace's] relationship to Maecenas in a certain, known way: Horace speaks truth to power the way Bion the cynic spoke to Antigonus. And thus an entire, pre-existing theoretical apparatus that lionized such relationships between truth-telling philosophers and kings as both helpful and necessary (the "king's confidant") comes into play to help imagine the poet's outspokenness in the same terms: Maecenas needs a man of that kind in his house, and that's the kind of (royal) house he runs. ${ }^{219}$

It takes nine months before Maecenas makes contact again asking Horace to join his circle of friends. It is held that the invitation came at the end of 38 B.C. or early 37 B.C. The poet writes in lines 61-64:

\begin{abstract}
abeo; et revocas nono post mense iubesque
esse in amicorum numero. magnum hoc ego duco

quod placui tibi, qui turpi secernis honestum,

non patre praeclaro sed vita et pectore puro.
\end{abstract}

(I withdrew; and nine months later you called me back and asked me to join your circle of friends. I consider it a great honour that I found favour with you, who distinguishes between the unworthy and the worthy not because of a famous father but because of an undefiled life and integrity).

Horace recalls in S.1.6.63-64 Maecenas' powers of discernment, which he praised before in S.1.6.5-8 and S.1.6.51-52. The poet obviously sees himself as one worthy of Maecenas' friendship on grounds of his way of life and his integrity. He will continue offering the evidence of his worthiness in S.1.6, as he did in the previous poems of the first book of Sermones and will do in the following. A reference to Maecenas powers of discernment returns in S.1.9.44-45, where Horace replying to the pushy fellow says:

219 For my view on Bion as a model for Horace, see also my discussion of Horace as a political commentator in section 1.1. For Horace's style as to how to deliver critical commentary, see my discussion of S.1.3.29-37 and the opening of S.1.4. For Bion, see Kindstrand (1976, 14-17). Bion of Borysthenes (ab. 325 - ab. 250 B.C.) originated from Olbia a town by the mouth of the river Borysthenes (modern Dnieper). Bion describes his parentage to king Antigonus II Gonatas of Macedonia. His father was a freedman. In addition to the putative reference to Bion in S.1.6 suggested by Freudenburg, Horace once actually refers to Bion in Ep.2.2.60. 
Maecenas has few friends, but he is a man of good judgment and uses this most skillfully to choose those friends.

But, before presenting a brief account of his youth in Venusia and his years in Rome where he received his education, Horace humbly admits in lines 65-66 a few minor faults (vitiis mediocribus ac mea paucis), that spoil his otherwise sound nature (mendosa est natura, alioquin recta). These are presumably the same unspecified innocent ones he mentioned in S.1.3.19-20 ("what about you? You have no faults?” Yes indeed, but different and perhaps lesser ones) and in S.1.4.130-131 (although I am in the power of minor, innocent ones). In line 68, he calls himself a happy man that he is free from those faults that bring ruin, such as avaritia (greed) and sordes (meanness), the faults of S.1.1, or mala lustra (visiting brothels), the faults of S.1.2. For the good cause of his credentials, Horace adds in lines 69-71 to his self-praise:

\author{
purus et insons \\ (ut me collaudem) si et vivo carus amicis; \\ causa fuit pater his \\ (if, to blow my own trumpet, I live a pure and innocent life and if I am cherished by my friends, \\ this is because of my father) $)^{220}$
}

He claimed already in S.1.4.129 that his father taught him the moral lessons (described in S.1.4.103-128) that kept him free from those vices. He emphasises in line 71 his father's work, who took him to Rome for his education. I have discussed S.1.6.71-78 in detail in section 1.3.2. Horace mentions in line 71 that his father was poor owning a lean small piece of land (macro pauper agello) in or near Venusia. Gowers (2012, 237) observes that " $\mathrm{H}$.[orace] presumably exaggerates the poverty of a father who could evidently afford Roman schooling and, later, student life in Athens; the tiny plot contrasts with both Maecenas' and Lucilius' extensive estates.” However, I suggest that Horace makes not only the point that his father was not rich, but also that he did not belong to the emerging class of provincial nouveau riche. His father did not squander his money on fancy projects or extravagant displays of wealth, but used the necessary funds for a good education of his son. Thus, he enabled young Horace to move in the best milieu in Rome, that of an eques atque senator (knight and senator). Horace makes in S.1.6.7178 , as part of his credentials, functional references to several aspects of his social and cultural background which should build up Maecenas' regard for him. He refers in this short section to his father's parsimony, to his departure from provincial Venusia, to his good education in Rome living in a milieu where he encountered the old Roman values and the traditional way of life and probably picked up the right political ideas.

220 I owe the rendering of $u$ t me collaudem to Gowers $(2012,236) /$ Palmer $(1885,199)$. 
Lines 71-82 add to my reading of the role of Horace's father which I discussed at S.1.4.103-133 ${ }^{221}$. Horace writes in S.1.4.105-108 that his father taught him the moral lessons which laid the foundation of his outlook upon life. I do not read these lines to mean that his father actually sat with Horace teaching him moral philosophy. The latter point is reinforced by what he writes in S.1.6.81-82, namely that in Rome his father himself, a most uncorrupted guardian, was present with his support as I went round all my teachers (ipse mihi custos incorruptissimus omnis/ circum doctors aderat). The father was involved as he felt responsible for a good education, but did not want to be his son's one and only moral guardian..$^{222}$

We saw in S.1.4 that Horace says that the traditional way of life is handed down to him by his Roman forefathers in general. Thus, the role of "the father" in the narrative is that of a link between the generations symbolizing the continuity of the traditions. I do not interpret the passage S.1.4.103-133 as autobiographical, but as Horace expressing that he grew up in a milieu having respect for the old Roman values. He confirms this in S.1.6.76-78, when he narrates that his father took him to Rome for his education (see also section 1.3.2). He writes: sed puerum est ausus Romam portare, docendum/ artis, quas doceat quivis eques atque senator/ semet prognatos (but he dared to take his boy off to Rome, to be taught those studies which any knight or senator would have his own children taught). Oliensis $(1998,34)$ observes at S.1.6.76 (est ausus) that "this is, moreover, an admirable audacity, exercised not on his own but on his son's behalf, and for the most moral of reasons: the father takes his son to Rome because he believes in the intrinsic moral value of a good education - a belief confirmed by his son, who attributes to his education the good character he claimed in the immediately preceding lines.” This should convince Maecenas. Horace was to be educated within a milieu of the social elite (eques atque senator) in Rome, in which it was likely that he would move within circles where the old values were still upheld. The role of "the father" in the narrative is that of an enabler. Horace says both in S.1.4 and in the present lines of S.1.6 that the right way of life was handed down to him

221 For Horace's father's role in S.1.6, see Oliensis (1998, 33-34); Schlegel (2000, 108-119).

222 Contrary to Harrison (1965, 111-112): "that to do this [acquiring this basic decency through moral lessons] adequately being beyond his [father's] slender resources, kept me at home, and instructed me himself by dint of simple precept and example." See also Brown (2007, 159). Also contrary to Gowers $(2012,238)$, who states with reference to doceat (S.1.6.77): “doceat: generic subj. H.[orace] perpetuates the myth that aristocratic Roman fathers taught their own sons" and to Gowers (2012, 239), who with reference to S.1.6.81-82 gives Horace's father the role of paidagōgos: "H.[orace]'s father himself acted as his paidagōgos as he visited his teachers." I read the lines as a description of the father feeling responsible for a good education of his son, and not as "another case of displaced abjection: the freedman [the father], despising slaves' morals, refuses to trust one as his child's moral guardian” (Gowers, 2012, 239). I concur with Oliensis $(1998,33)$ at S.1.6.76-78: "In Satires 1.6, the educational mantle passes from the father to the schoolmaster. Horace's father's contribution was to ensure that his son got a proper schooling, not in backwoods Venusia but at Rome.” 
by good Romans in general, by his milieu in Venusia and that in Rome during his time with Orbilius, fond of flogging, who dictated to him as a boy the poems of Livius Andronicus, as he writes in Ep.2.1.69-71: carmina Livi/ [...], memini quae plagosum mihi parvo/ Orbilium dictare (the poems of Livius [Andronicus] [...], which I remember that Orbilius, who was fond of flogging, dictated to me as a boy). Contrary to the sons of the centurions whom he left behind in provincial Venusia, Horace claims that he belonged truly to the elite, when he was a schoolboy in Rome. He describes in lines 72-75 that the sons of important centurions in Venusia went to the local school (Flavi ludum), with their casket and writing tablet hanging from their left shoulder, bringing their eightpence school-fee on the Ides (laevo suspensi loculos tabulamque lacerto,/ ibant octonos referentes Idibus aeris). Their circumstances were much inferior to his in Rome amongst the sons of aristocrats. He relates in lines 78-80 his life in Rome as very much part of the aristocratic class with attending slaves, where money was no object: S.1.6.78-80 reads:
vestem servosque sequentis,
in magno ut populo, si qui vidisset, avita
ex re praeberi sumptus mihi crederet illos.
(if anyone had seen my clothes and the slaves who attended me - as is usual [for the rich] in a great city - he would have thought that those expenses were paid for me from an ancestral estate).

His life in Rome was so comfortable that one would have thought that he came from an old family with all the trappings that go with such a background.

Like in S.1.4, the father-son relationship in S.1.6 is a much debated issue. I read Horace's account of the relationship within the context of his presenting his credentials to Maecenas. That is to say that I consider parts of Horace's narrative about his father poetic fiction. I argue this at the appropriate places in S.1.4, where his "father" symbolizes the continuity of the good Roman traditions and the poet tells us how these were transferred to him, and in S.1.5 with respect to the passage that refers to Venusia and the naturalness of his upbringing. ${ }^{223}$ Schlegel gives a literary interpretation to the father-son relationship in S.1.6 stating at several places in Schlegel (2000, 93; 105-106; 114; 116) that

this father [in S.1.6] is also the cause of Horace's friendship with Maecenas. Just as the character that the father formed in Horace [by his education] makes the son's satire harmless (not deservingly suspectum) and adequate to the condition and status of poetry, so Horace's character allows for the relationship with Maecenas. The father is explicitly seen as the cause of the primary element in Horace's poetic life, his character. [...] In 1.4 and 1.6, then, his [Horace's] focus on his

223 For the "father"- role in S.1.4, see my discussion of S.1.4.115-143; for the "father"- role in S.1.5, see my discussion of S.1.5.86-90. 
father serves his poetic program and contributes importantly to the task of identifying his genre with this persona.

Schlegel recognizes that the "father's" role enables Horace to further his poetic programme, but she does not identify any other purpose, such as for example making clear to Maecenas that he is a worthy member of the latter's circle of friends. I have doubts about her linking up Horace's character exclusively with him writing satire. First, there is not much satire in S.1, which, in my opinion, was not written with the intention of producing censure poetry. Second, Horace stopped writing his Sermones after a few years and changed to a genre, that is very different, the Carmina, while the relationship with Maecenas remained. Did his "satire"- character fit the Carmina as well? He wrote most likely eleven carmina of the first book between 35 and 30 B.C. (see note 326). Thus, it is feasible that at the time when he still wrote $S .1$ he developed a "lyric programme," which he effectuated when he wrote S.2.

Horace continues his praise of his background and the values which he had been taught. He arrives in S.1.6.82-84 at the conclusion that so far he has managed to remain uncorrupted, which is virtue's first credential, as his father kept him free not only from shameful action but also from scandal (pudicum,/ qui primus virtutis honos, servavit ab omni/ non solum facto, verum opprobrio quoque turpi). Although Gowers (2012, 239) does not suggest that S.1.6.82-84 is part of Horace's expounding his credentials to Maecenas, she recognizes two aspects of the passage which indeed may hint at this conclusion. Firstly, she renders pudicum,/ qui primus virtutis honos, servavit in lines 82-83 as "he kept me uncorrupted, which is virtue's top credential," using the very word. Secondly, she states about this passage that "H.[orace] tends to stress his unblemished morals rather than his literary gifts." I note that "stressing his unblemished morals" agrees well with my interpretation of the context of the passage, that is that $S .1$ is a book with Horace's credentials for Maecenas. It should also be noted that Horace uses the word honos in line 83 meaning "repute/esteem," whereas the meaning of honor (= honos), used three times in the first main section S.1.6.7-44, is that of "high office." It is probable that honos in line 83 refers back to honor (high office) in the first section, which is concerned with social mobility and gaining office. ${ }^{224}$ Thus, Horace connects in this sermo on the one hand his moral credentials and the teaching by his milieu and his father, described by him in S.1.6.4584 , with on the other hand the issue of social mobility, described in the first section S.1.6.7-44. In the third section S.1.6.85-131, he will offer his views on his own future.

From line 85, Horace starts to think aloud about his own prospects; he involves both his father and Maecenas. It is about time that he lets Maecenas know what his

224 I owe the rendering of "credential” for honos to Gowers (2012, 239). Horace uses both the word (and word-forms of) honor and honos. In S.1 he uses these six times, of which five times in S.1.6 $(S .1 .6 .11,15,19,49,83)$. 
own image of his future is. He does this in a rather indirect manner focusing on his “father." He says in lines 85-88:

nec timuit sibi ne vitio quis verteret olim

si praeco parvas aut, ut fuit ipse, coactor

mercedes sequerer; neque ego essem questus: ad hoc nunc

laus illi debetur et a me gratia maior.

(and he was not afraid that someone might one day reckon it his fault, if I were to go after small rewards as an auctioneer or, like himself, as a collector of money; nor would I have complained: but, as things are, I owe him all the more praise and thanks)

I interpret these lines not only as words of gratitude to his father, who is not to blame if Horace does not make a career, but also as indicating to Maecenas that his political ambitions may be limited. He expounds his feelings of gratitude for his education in the following lines: he says in line 89 that as long as he is in his right mind he would not regret having him as his father (nil me paeniteat sanum patris huius). And, he writes in lines 90-92 that - if he cannot achieve his ambitions - he will not blame his parents, as many others do: non, ut magna dolo factum negat esse suo pars,/ quod non ingenuos habeat clarosque parentis,/ sic me defendam (I would not defend myself, as the majority does, who say it is no fault of theirs that they do not have free-born or distinguished parents). We read in lines 93-97 that Horace thinks differently:

\footnotetext{
nam si natura iuberet

a certis annis aevum remeare peractum

atque alios legere ad fastum quoscumque parentis,

optaret sibi quisque, meis contentus honestos

fascibus et sellis nollem mihi sumere,

(for if nature ordered us to repeat our past life, beginning at a certain age, and to choose any other parents each of us wished for himself to match his pride, I would be content with my own and I would not want to take those who were distinguished by the rods and chairs [marks of high office])
}

Horace would not want to replace the naturalness and cultivation of his milieu by the insincere distinctions of high office. He addresses in lines 98-99 directly Maecenas, when he says that he is certain that Maecenas, who was according to Gowers (2012, 241), quoting ps.-Acro, known for his "disdain for senatorial office," will understand that he declines the troublesome burden to which he was never accustomed: sanus fortasse tuo, quod/ nollem onus haud umquam solitus portare molestum (but perhaps sound to you, that I would not want to bear a troublesome burden to which I was never accustomed). He will make the same point in the last lines of the poem, S.1.6.128-131. In lines 100-110, he describes what he dislikes in the way of life of those who hold high office recalling Tillius of S.1.6.24, the ambitious freedman's son, who had an erratic political career, but remains otherwise unidentified. He was probably Horace's fiction, who was not modelled after a historical person. Horace made him an 
embodiment of political ambition leading to his ruination. The message to Maecenas is clear: it is the same as that in S.1.6.17-18 and S.1.6.20-22, when he decided that he wants to stay out of practical politics.

He gives his arguments for his rejection of high office from line 100, and he sounds determined not to seek the obligations which go with high office and a political career. He spells those out in lines 100-104:

nam mihi continuo maior quaerenda foret res,

atque salutandi plures, ducendus et unus

et comes alter uti ne solus rusve peregreve

exirem; plures calones atque caballi

pascendi, ducenda petorrita.

(for immediately I should have to seek extra financial resources and there would be more calls to exchange, to take one or two companions so as not to go alone either into the countryside or abroad; I should have to maintain more servants and feed more horses, and to have more carriages)

Horace does not specify in line 101 whether he imagines receiving callers or paying visits, but he most likely expects that he in the course of a political career must fulfil both disagreeable duties. ${ }^{225}$ His objections to being involved in the political business come down to losing control of his way of life and being forced to take account of the opinions and actions of other people: he is rather on his own, as we will read in the lines that follow. In S.1.6.100-104, he also exaggerates a little, which we see again in the following passage. Horace gives the passage from line 100 to the end a satiric trait, one of the few in S.1, depicting in lines 104-128 the attractions of simple life. I suggest that he writes tongue-in-cheek in the latter passage being his way of telling Maecenas that he is not aspiring to a traditional career in political business. Nisbet $(2007,10)$ recognizes the irony, and states: "In [S.]1.6, [...] he gives an attractive and no doubt exaggerated picture of his simple life (104-31) [...]; he thus tries to avert the malice that attended his new success." The whole picture of his youth, his education and his simple life is indeed rather exaggerated. I interpret this as a support of my view that much of $S .1$ is fiction, in which exaggeration has the function of illustrating that he is not connected in any way with the world of the nouveau riche and other upstarts. Horace will remain his simple self, who is not in competition with Maecenas or other politicians. I concur with Nisbet that he tries to avert the malice, but not that of "new success," as it still has to materialise. He tries to avert future involvement in politics.

Horace refers overtly to his personal freedom in lines 104-106:

$$
\text { nunc mihi curto }
$$

ire licet mulo vel si libet usque Tarentum,

mantica cui lumbos onere ulceret atque eques armos:

225 The rendering of salutandi plures in line 101 is conform Gowers (2012, 241-242). 
(as it is, I am free, if it pleases me, to go all the way to Tarentum on a gelded mule; the rider and his bag make the mule's loins and flanks sore from the weight).

He also informs Maecenas in line 106, that although being free to choose, this does not mean that he gives way to the despicable manners of the new rich. Travelling cheaply on a long journey all the way to Tarentum by riding a mule is not comfortable; certainly not for the animal, which may imply that the rider has to travel slowly. However, the eques Horace travels in accordance with his simple, but civilized style, and thus according to Gowers $(2012,243)$ "has been more successful in renouncing the signs of his humble origins" than Tillius, who enters on the scene again after we last heard from him in lines 24-26. He is Horace's fiction impersonating an ambitious freedman's son or a man of humble descent, who had an erratic political career. Horace made him an embodiment of political ambition, who is depicted as one who managed to become praetor, "an increasingly un-exclusive office in the unsettled years of the triumvirate: in 38 B.C. there had been no fewer than sixty-seven praetors (Dio 48.43)" (see Gowers, 2012, 244).

Horace constructs in lines 107-111 a contrast between two freedman's sons: himself, the civilized and unassuming one, and fictitious Tillius, the nouveau riche who liked to show his advance in society and to display his wealth. The poet says to him in line 107 that no one will reproach me (Horace) with meanness, as one does you (obiciet nemo sordis mihi quas tibi). He imagines Tillius as one who feared to be considered mean if he were to make his journeys without a "proper" escort of servants: the reproach of meanness was for many of the new rich a serious lack of appreciation, as they wanted to be seen to belong to the class of people for whom money is no object, that can be showered over their clients. Thus, Horace gives a humorous description of Tillius on his short fictitious journey of only sixteen miles from Rome to Tibur (modern Tivoli), which he makes with a retinue of five servants, rather different from the way in which Horace imagined that he travelled on his mule to Tarentum. Horace mocks Tillius' pretensions in lines 108-109 cum Tiburte via praetorem quinque sequuntur/ te pueri lasanum portantes oenophorumque (when on the road to Tibur five slaves follow you, praetor, carrying your chamber-pot and wine-holder). In lines 110-111 Tillius is called ironically praeclare senator (great senator), which is perhaps too much honour, although he seems to do very well. However, Horace does not aspire after his rank, because he lives more comfortably than Tillius would, in this and a thousand other ways (hoc ego commodius quam tu, praeclare senator,/ milibus atque aliis vivo). He will narrate his putative day in the city in the final part of the third section.

Horace extols his ideas of a free and simple life in the city in S.1.6.111-128. ${ }^{226}$ When he wrote $S .1$, he had not yet received the free use of his Sabine estate from Maecenas (see section 1.4). He testifies to enjoying the peace and quietude of this estate in many

226 For Horace’s typical day in the city, see also Coffey $(1976,77)$. 
of his poems, amongst other S.2.6, Carm.1.20, 2.18, 3.8, and Ep.1.14. However, for the time being, he has to relax in Rome itself, which he imagines to be perfectly possible. In S.1.6.111-118, he tells us that wherever he wants to go, he goes on his own (quacumque libido est,/ incedo solus). He is prudent spending his money when he buys his simple food: percontor quanti holus ac far (I ask the price of greens and flour). At the end of the afternoon he wanders through (pererro) the Circus Maximus and the Forum where he listens to the fortune-tellers (adsisto divinis), which presumably keeps him in touch with common people. It sounds all very prosaic and not so pretentious as the entertainments of the parvenus. Then, homewards for a simple meal of leeks, peas and pasta (inde domum me/ ad porri et ciceris refero laganique catinum) served by only three slaves (ministratur pueris tribus). His table of cheap marble (lapis albus) holds a simple dinner set with among other things cups (pocula duo), a cheap rinsing-bowl (echinus/vilis) and utensils of cheap Campanian earthenware (Campana supellex). No silver to be seen.

In the three lines that follow, S.1.6.119-121, Horace illustrates his objections to being deeply involved in political life and vindicates his freedom in an original scene, in which the statue of Marsyas plays the leading part. This statue, a satyr with right hand raised, was placed in the Forum, and was according to Gowers $(2012,247)$ “traditionally regarded as a Roman 'Statue of Liberty' (Serv. Ad Aen.3.20, 4.58 in foro positus libertatis indicium est, qui erecta manu testator nihil urbi deesse [placed in the Forum as a sign of freedom bearing witness by the raised hand that the city lacks for nothing]) or plebeian symbol (Wiseman 2004:68-70).” Lines 119-121 read:

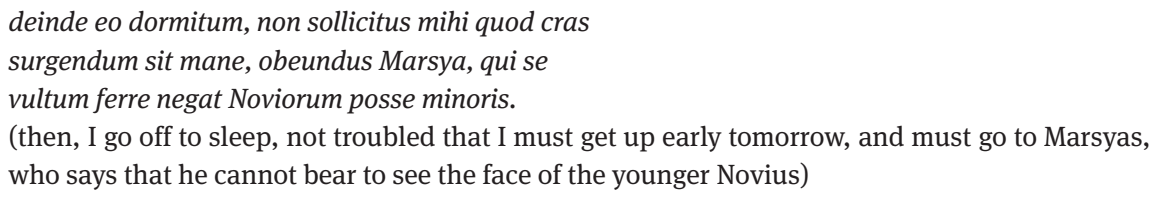

Horace acknowledges gratefully that he is not obliged to participate in the "tedious urban duty" of paying morning calls to Marsyas as his patron. He constructs on the one hand a very original congruence between Marsyas the popular defender of freedom and his own free choice of not having to make morning calls to his patron, and on the other a paradox between Marsyas as his imagined patron and Maecenas as his amicus. The raised arm of Marsyas can be interpreted as a gesture of abhorrence, which Horace explicates in line 121 as being directed against younger Novius, presumably the son of the freedman of line $40 .{ }^{227}$ The latter symbolizes the upstarts,

227 See for the raised arm, Porphyrio (ad S.1.6.121): “duo Nouii fratres illo tempore fuerunt, quorum minor tumultuosus fenerator fuisse traditur (at that time there were two brothers Novii, of whom is said that the younger was a noisy money-lender) in Meyer (1874, 225); see also Gowers (2012, 247). 
who meet every morning their patron and of whom even Marsyas would abhor. This is not the kind of company that Horace would wish to choose.

Next, in S.1.6.122-128 he tells us about his favourite quiet day on his own. He either stays in bed till ten o'clock (ad quartam iaceo) and then takes a stroll (post hanc vagor), or he reads or writes something for his enjoyment on his own (aut ego lecto/ aut scripto quod me tacitum iuvet) (lines 122-123). Gowers (2012, 248) interprets tacitum as "H.[orace] pleases himself, rather than a patron." I concur with her that Horace does not appreciate the status of client paying morning calls with many others to his patron. ${ }^{228}$ He has made this abundantly clear by his description of such an imaginary call to Marsyas. Horace expresses in S.1.6.122-123 the enjoyment he finds in his intellectual pursuits of reading and writing and discussing the output with his friends and associates of the circle of Maecenas, as he said in S.1.4.73-74 and will say again in S.1.10.81-88. Next, he is anointed with a good oil (unguor olivo), unlike the miser Natta who uses oil taken from his lamps (fraudatis lucernis). Horace says in S.1.6.125-126 that the warmer sun (at the end of the morning) persuades him, getting tired, to go to the baths, and avoid the Campus Martius and the ball-game (ast ubi me fessum sol acriorire lavatum/ admonuit, fugio Campum lusumque trigonem), or alternatively avoid crowds and midday heat when the text of the majority of manuscripts is used: rabiosi tempora signi (the season/hour of the mad sign in the heavens) instead of Campum lusumque trigonem. ${ }^{229}$ Brown $(2007,164)$ suggests that the former phrase alludes "to the sun's midday heat," although he also states that it is "the most implausible periphrasis for an idea already expressed by sol acrior." Horace argues in the passage that he wants to be on his own with his reading and writing. He wants to avoid crowds and midday heat: rabiosi tempora signi can be read either as a repeat of the warmer sun (sol acrior) as such, or as the effects of the warm sun, thus accentuating his aversion to crowds and heat. In view of the context, I favour the latter interpretation. Abstemious Horace having taken breakfast is not hungry (pransus non avide), but has just enough for lunch not to starve all-day (quantum interpellet inani/ ventre diem durare) and spends the afternoon idling at home (domesticus otior).

In her (1998, 34-35) description "of a typical day in the poet's life" Oliensis considers Horace's ambition and raises again the issue of Horace as a social climber. I read her present statement that she is not saying that Horace was a social climber, but

228 Conform Gowers (2003, 80): "Horace is no scurrying client with urgent duties, but a solitary being who sleeps late and dictates his own timetable."

229 For the textual problem of the ending of S.1.6.126, see Brink (1987, 30-31); Brown (2007, 164); Gowers (2012, 248-249). Brink states that the problem is not satisfactorily resolved. Brown mentions two options: "the phrase can scarcely mean 'the season of the rabid dog-star'(conform 7.25-6), which, even if the allusion to the time of year had point, Horace had no power to avoid, or 'the hour of the rabid sign' alluding to the sun's midday heat, the most implausible periphrasis for an idea already expressed by sol acrior." 
that on the contrary he needs to be "distinguished from the parasitic social climber." She says:

It is a remarkable feat that the poem commemorating the beginnings of Horace's friendship with Caesar's right-hand man leaves us feeling that Horace is one of the most unassuming men in the world. The effect is enhanced by the beguiling description of a typical day in the poet's life with which the poem concludes. The description is framed as if it were proof positive of the advantages attending a life free from political ambitions: "In this way my life is more agreeable than yours, eminent senator" (hoc ego commodius quam tu, praeclare senator,/...vivo, S.1.6.11011); "This is the way men live who are free of the wretched weight of ambition" (haec est/ vita solutorum misera ambitione gravique, 128-9). But the real burden of the intervening description is to distinguish Horace not from the political aspirant but from the parasitic social climber.

Contrary to Oliensis' view of Horace's routine, Gowers (2012, 244) interprets S.1.6.111128 as that "indeed, many of the activities described shadow the routines of clientela." Below, one will find my view on the issue, that is that Horace reveals by his story of his daily routine that he is not a social climber.

I suggest that, just like a number of other narratives in S.1.6, the account in lines 111-128 is not autobiographical, but again fiction. Contrary to both Oliensis and Gowers, I interpret this passage as Horace's answer to the short passage about Tillius that precedes this one, and indeed to many other passages in this and previous sermones about the ostentation of wealth by many of the new men in politics and by the new rich. Further, this passage is consistent with the context of the book as a whole in which the poet tells Maecenas that he prefers the life outside the limelight of the political business and a continuation of his comparative freedom. Freudenburg $(2010,282)$ states about this passage (lines 111-128) that

as the philosopher gifted with leisure in Satires 1.6, Horace has time to stroll through the forum at dusk, to read and write and think great thoughts. [...] But the poet's daily routine undergoes a drastic shift in Satires 2.6 to become the exact opposite of that earlier picture. [...] He [Horace] spends the day chasing about the city, frantically pursuing errands first for Maecenas, then for the scribes, and so on, but never having any time for himself.

Freudenburg then poses the question: “where, then, is the 'true' Horace in all of this, and what can we really know of his real life, his opinions, and his routines?" My interpretation of both S.1.6 and S.2.6 and the putative contrast in Horace's attitude in the two poems differs significantly from that of Freudenburg. Firstly, Horace does not present himself in S.1.6 as "the philosopher gifted with leisure," but as the man who wants to remain independent and does not wish to exist like the majority of the upstarts. However, his Epicureanism ought to be considered here indeed. I noted in my discussion of S.1.3.78 that Horace's choice of words ponderibus modulisque (weights and measures) demonstrates his Epicurean disposition (see also note 113). According to Hanchey (2013), Cicero criticized the Epicureans severely for their selfishness and consequent tendency to avoid political life. He saw this as a serious 
threat to the survival of the state. ${ }^{230}$ One might therefore conclude that Horace's description of his typical day proves Cicero's point. My conclusion differs essentially. Horace does not aspire to be an outsider in Roman politics, but seeks to participate in his own way as a commentator and not as a politician. His Epicurean views make him aware that he needs the freedom to organize his life in his own way to be able to reflect and study. Secondly, S.2.6 contrasts the displeasure, hassle and irritation of city life with the peace and bliss on his Sabine estate, which is what he prayed for (S.2.6.1: Hoc erat in votis). On his farm he is free, he can enjoy the conversations with friends: in other words he takes as much pleasure in the kind of existence on his farm in S.2.6 as he described eight years before as his liking in S.1.6.122-124. Thus, S.2.6 conveys the same message about Horace's preference as S.1.6. If his goal is to become involved in politics from the sidelines, he needs his independence in order to be free to say what he must. Concerning the point made by Gowers that Horace shows himself a parasitic social climber, I offer three arguments against this view. First, if he were a social climber, he probably would have given a very different description of a typical day in his life; one in which he imagines himself not visiting fortune-tellers but theatres, sitting in same row as Novius in line 40 and hoping for the front row, or attending great dinners with Maecenas rather than a simple meal of leeks and peas at home. Second, Horace's appreciation of being admitted to the circle of Maecenas is not only his social elevation, but as much his association with his friends and colleagues, Virgil, Varius and Plotius. He writes, for example, among others about them in S.1.5.42: neque quis me sit devinctior alter (and nobody is more attached to them than I), and in S.1.6.54-55 about Virgil and Varius optimus olim/ Vergilius, post hunc Varius, dixere quid essem (some time ago the excellent Virgil and after him Varius told you what I was). In Carm.1.3., he professes his feelings of friendship in a moving propempticon for Virgil, who sails for Greece, while Horace prays for a safe journey. ${ }^{231}$ Third, in S.1.9, he shows what he thinks of social climbers, when he is confronted with the pest, a prototype of the ambitious and crude men who emerged in Roman society.

The finale of S.1.6 consists of only three lines and two words. He says in lines 128-129 that such a life is only for those who are released from the burdensome and pitiable ambition (haec est/ vita solutorum misera ambitione gravique). Thus, he restates in different words what he said before in the poem: in line 22 quoniam in propria non pelle quiessem (as it would not make me feel good), which I read as that he does not aspire to a political career, as he would not feel good being a politician, and in lines 98-99 that he would not want to bear a troublesome burden to which he was never accustomed (quod/nollem onus haud umquam solitus portare molestum). In his final lines, he voices his gratitude that he is not the son of one of the established families, that would have deemed him to pursue a career in politics and probably finish as a

230 For a bibliography of Cicero's anti-Epicureanism, see Hanchey (2013, 119, note 2).

231 For Horace's friendship with Varius, Virgil and other poets see section 1.3.2. and note 31. 
senatorial candidate. In lines 130-131 he says: his me consolor victurum suavius ac si/ quaestor avus pater atque meus patruusque fuissent (I find comfort in these [his way of life] as I shall live more pleasantly than [I would have lived] if my grandfather, my father and my uncle each had been a quaestor). In addition to his aversion to the political business, Horace probably also hints again at the same point mentioned earlier in my discussion of Horace in the role as gentleman jester (at S.1.3.31-32, section 2.2.2). At the time of writing S.1.3, and indeed also S.1.6, (early 30s B.C.), Horace does not want to be involved politically. He needs to guard his independence to keep the opportunity to vent controversial political opinion, without taking sides. However, I noted already at the discussion of S.1.3.31-32, that he did not keep silence in the case of major contemporary political issues. Griffin $(1993,8)$ observes that Horace did not take sides until the Battle of Actium. He says of the Epodi that those "contain two rousing poems on Actium, [...] probably composed shortly before the publication of the book [...]: vigorous statements of partisanship, devotion to Caesar's heir and loathing of his enemies, waited until after the Battle of Actium. Much prudence, perhaps, but little political passion.” I differ from Griffin's view; I recognize already in S.1 both a number of political statements and Horace taking sides with respect to the outcome of one crucial issue, that is the power struggle between Octavian and Marc Antony.

In summary, I identify three sections in S.1.6. In the first, S.1.6.1-44, Horace presents his views on social mobility and eligibility for public office recognising the significance of one's social background for a political career: low birth should not be an obstacle, and high birth no guarantee, although being well-born is a recommendation for high public office. In the second section, S.1.6.45-84, he records his first meeting with Maecenas in lines 45-61, and he presents his moral credentials and more details of his personal background and history, such as the teaching by his milieu and his father in lines 61-84. The third section, S.1.6.85-131, contains his views on his own future, which he doesn't envisage as one in the political business, as a career in politics would not make him feel good. S.1.6 is the next sermo in Horace's series of credentials, in which he presents himself as a reliable member of Maecenas circle sharing the latter's political convictions.

\subsubsection{Sermones 1.7 and 1.8: Threats from the East: Parthia and Egypt}

Horace changes the emphasis slightly in S.1.7 and S.1.8 (and indeed in S.1.9) compared to the previous six sermones. The focus is still on proving his worth to Maecenas, but his approach differs from the one he used so far. Before, he raised for discussion subject matters of social and political ethics stressing the common ground with Maecenas, which were designed so that the latter would recognize readily Horace's suitability for association. From S.1.7, Horace sounds confident that he will succeed - or already has succeeded - in his efforts to find a place within the circle of Maecenas and he chooses as his subjects for discussion strategic issues of military and foreign policy. He does 
this presumably in order to demonstrate that he also has a contribution to make in those fields and again to show that he also supports the policies of Octavian and Maecenas. The subjects he raises are both the contemporary issues of the unresolved threat by the Parthians in the East and the alliance of Cleopatra and Marc Antony. Before I analyse the poems to see whether and how he informs us of those points, it is useful to first briefly chart the historic context of the poems. Thus, after a few words about Crassus' defeat in the battle of Carrhae in 53 B.C., I focus in the description of the historic context on the period between 44 and 31 B.C., in particular the conflict between Octavian and Marc Antony, and the disastrous failures of Marc Antony's leadership, that became apparent from the Parthian campaign and in his association with Cleopatra. The continuation of the civil war caused by these events was a major political issue at the time when Horace wrote S.1.7 and S.1.8. ${ }^{232}$

Carrhae in Parthia is where Crassus was defeated by the Parthians in 53 B.C. with the loss of 20.000 men killed and 10.000 taken prisoner and the loss of the legionary standards. In the thirties and twenties B.C. this was still felt as an affront to Rome that required the restoration of Roman honour, one way or another. Efforts to resolve the issue by military means, such as the Parthian campaign of Marc Antony in 36 B.C., when he crossed the river Araxes but was chased out of Armenia, had been a failure. ${ }^{233}$ When Augustus' power looked secure in 27 B.C., resolving the Parthian problem was a matter of high priority for the princeps. He succeeded not by military means, but by concluding a treaty; the standards returned to Rome in 20 B.C.

The murder of Julius Caesar on 15th of March 44 B.C. marked the beginning of the end of the civil wars, which had ravaged Italy and Rome for many decades. Immediately after the murder, Marc Antony, at that time consul with Caesar, took charge, convened the Senate and reached a compromise which meant that the murderers of Julius Caesar would not be charged, but that Caesar's measures were to be maintained..$^{234}$ Octavian hastened to Rome. As a result of the opposition of the people against the clemency shown to the murderers, Brutus and Cassius were forced to leave Rome. Brutus went by way of Macedonia and Illyricum to Greece and was granted by the Senate maius imperium in Greece in 43 B.C. When Octavian insisted on punitive measures against the conspirators, Antony resisted, but he eventually had to yield to the greater military power and the popularity of Octavian among the people. Octavian pressed on and in 43 B.C. at the age of only nineteen he gained his first major political victory when the senate appointed him consul. Furthermore, he

232 For the historical context of the Late Republic and the Early Empire, see Boatwright et al. (2004, 267-316); Brunt (2004a); Galinsky (1996, 80-140; 2005); Naerebout \& Singor (2004, 253-276; 302-307); Raaflaub \& Toher (1993); Wallace-Hadrill (2005); Zanker (2010). This summary of the historical context of the conflict between Octavian and Marc Antony is an adaptation of parts in Weeda (2010, 24-26).

233 For Virgil's reference to Marc Antony's campaign in A.8.728, see Weeda \& van der Poel (2014, 595). See also Lemaire (1819, 472) and Page (1962, 250).

234 Yavetz (1993, 29-30) offers an interesting analysis of the different options which Antony faced. 
convinced the senate to condemn the murderers. Brutus and Cassius were proscribed and banished. Brutus, however, had in the meantime taken control of Asia illegally. Octavian and Antony were reconciled and together with Marcus Lepidus they formed the Second Triumvirate to restore order. ${ }^{235}$ In the year 44/43 B.C., Horace joined Brutus.

The civil war entered a new phase when in 42 B.C. Antony and Octavian advanced eastwards against Brutus and Cassius. In October of the same year both rebels were defeated in the battle of Philippi after which they committed suicide. Antony stayed in the East to direct the war against the Parthians and in 41 B.C. he met Cleopatra; not for the first time, but this time their encounter had important consequences.

In the meantime, Octavian had to deal with other adversaries such as Fulvia and Lucius, the wife and brother of Antony. In 40 B.C. both escaped after being besieged in Perusia (modern Perugia) and died soon after. A more dangerous enemy was Sextus Pompey, who blockaded the coast of Italy at different places with his fleet from a base on Sicily, thus threatening the Roman grain supplies. With the aid of Antony from Egypt and of Lepidus from Africa, Agrippa, the faithful general and friend of Octavian, engaged Sextus. In 36 B.C. Agrippa defeated the navy of Sextus in a number of naval battles (the last was the battle near Naulochus) around Sicily. Sextus could escape to Asia Minor, where he hoped to join forces with Antony. Not much later Sextus was captured and killed. Horace wrote S.1. between 38 and 35 B.C.

In the struggle for power Lepidus saw his chance to push aside Octavian and he claimed command of the legions of Sextus Pompey. Octavian solved this in his own characteristic way by entering the camp of Lepidus' army and inviting the troops of both Lepidus and Sextus to accept him as their commander. He was successful and Lepidus was removed from the Triumvirate and exiled to a small provincial town. From then Antony was for Octavian the last obstacle on the road to absolute power.

From 40 B.C. until 33 B.C. Antony joined Octavian in a continuation of the Second Triumvirate, in which the former kept control of the eastern part of the empire. At the insistence of Octavian, he married Octavia in 40 B.C. Three years later Antony sent Octavia back home to Rome and he passed his time alternately between military campaigns in the East and the palace in Alexandria. Subjugating the territories in the East served not only the imperialistic aim of Rome, but also the political and territorial aspirations of Cleopatra. These aspirations were a strong empire led by her and Antony with Alexandria as capital, where the Greek intellectual power was to be paired with the political and military might of Rome and which would certainly not be subordinate to Rome. During those years she took Antony along in this ambition, which eventually culminated in the so-called Donations of Alexandria in 34 B.C., when Antony presented Cleopatra's children with some of the recently won lands. ${ }^{236}$

235 For five years they formed a Triumviri rei publicae constituendae (Triumvirate for the Restoration of the Republic).

236 Cassius Dio, 49.40.2-41.4. 
It would not take long before the struggle between Cleopatra and Antony on the one hand and Octavian on the other would be decided in arms. In 32 B.C. civil war flared up again and Octavian declared war on Cleopatra and Antony. ${ }^{237}$ As time passed Octavian provoked Antony more and more, among other matters by publishing the content of the latter's testament. In his public utterances Octavian made it appear that Cleopatra wished to destroy Rome and that Antony was wholly enslaved to her. Most probably this was not far from the truth. On $2^{\text {nd }}$ of September 31 B.C. the sea battle near Actium was fought and resulted in a deciding victory for Octavian and Agrippa. Antony and Cleopatra fled to Egypt and in 30 B.C. Alexandria was taken. Thus the succession of civil wars which had started in 88 B.C. with Sulla's march on Rome finished in 30 B.C. And although Octavian made it appear that the war against Cleopatra and Antony was a war against a foreign enemy, this conflict also has to be viewed as a continuation of the internal power struggles in Rome, which had dominated the best part of the first century B.C. The consequences of these wars had been terrible for Italy and Rome. Modern scholars estimate that during the civil wars 14 to $17 \%$ of the total number of adult male citizens had been enlisted in the army. ${ }^{238}$ It is impossible to determine the total number of victims among the civilian population in Italy and the total number of military losses, but over a period of nearly sixty years it must have been very substantial. In many parts of the country the administration had ground to a halt, public order was seriously affected and massacres and looting by groups of roaming soldiers and slaves were the order of the day. This contributed to the collapse of the economy and food supplies were seriously endangered by the reduced production in Italy and by the disturbance of grain imports.

Studying S.1.7, one notes that this sermo has not received as much attention of modern commentators of $S .1$ as many other poems in the book. ${ }^{239}$ Scholars considered the poem “a make-weight” (Brown, 2007, 165), or “think it is a failure” (Rudd, 2007, 66). ${ }^{240}$ This is presumably because the poem seems to have characteristics very different from

237 Cassius Dio, 50.24-28; the formal declaration of war was on Cleopatra only, as Octavian did not want the war to be seen as a civil war. It is likely that Octavian also had another motive as by leaving Marc Antony out he made it easier for the many Romans who had joined Antony's cause to change sides. 238 Conform Boatwright et al. (2004, 301). Estimates by Brunt (1971) and Hopkins (1987) (summarized in De Blois \& van der Spek, 2001, 209) present the following figures: in 83 B.C. 143.000 soldiers $=14 \%$ of the total number of adult male citizens, in 63 B.C. 120.000 soldiers $=12 \%$, in 43 B.C. 240.000 soldiers $=16 \%$, and in 33 B.C. 250.000 soldiers $=16 \%$. After Actium this reduces to: in 23 B.C. 156.000 soldiers $=9 \%$.

239 For S.1.7, see Anderson (1982, 79-83); Brown (2007, 165-169); Buchheit (1968); DuQuesnay (1984, 36-38); Gowers (2003, 82; 2012, 250-263); Henderson (1994); Rooy, van (1971); Rudd (2007, 64-67).

240 For an analysis of, among other matters, the last lines of S.1.7, see Henderson's (1994, 157) conclusion: "The poem does not even warrant the understanding of Persius' [final] 'exclamation' as a 'pun', of whatever quality to whoever’s ears, nor even as a ‘joke'.” 
the rest of the book, almost as if it does not form part of it. On the face of it, the subjectmatter of S.1.7 seems to differ from that of the other poems, namely that it seems to be concerned with events from the past that have no bearing on contemporary political issues, let alone that the poem can be read as one of his credentials. I intend to show that this poem can be properly interpreted as one of those. Hence, it follows that S.1.7 was most likely written between 38 - 36/35 B.C.

In S.1.7 Horace goes some five to seven years back when he narrates an event that presumably took place after he had joined Brutus in 44 or 43 B.C., and before Philippi and the death of Brutus in $43-42$ B.C. That does not mean that the story is an account of a real historic event; it may be one of Horace's fictitious narratives. Horace referred only once before openly in S.1.6.48 that he once was a tribune in a Roman legion, although he does not say that this was in Brutus' army and that he fought at the wrong side at Philippi. It was not before Carm.2.7, written after 30 B.C., that he mentioned explicitly his experience in the battle of Philippi. He touched in S.1.3.139140 on his own fortunate circumstances that he was accepted nevertheless within the circle of Maecenas by men of great charisma and importance, real friends. ${ }^{241}$ We also saw that Horace was very much aware of the potential burden of his wrong choice in the past for his position within the Roman elite in the future. This caused him to write his first book of Sermones in which he endeavoured to convince Maecenas and others of his worth. I will argue that Horace juxtaposes in S.1.7 the cultured milieu that he experiences after being admitted to Maecenas' circle and the crude and aggressive one of his past with Brutus, thus admitting in the present sermo openly his previous association with the republican cause. This makes $S .1 .7$ a poem with a special meaning.

Horace depicts a real or fictitious incident at a session of Brutus' circuit court as follows. He starts by introducing the two antagonists in the well-known case, according to Horace, in S.1.7.1-8.

\footnotetext{
PROSCRIPTI Regis Rupili pus atque venenum hybrida quo pacto sit Persius ultus, opinor omnibus et lippis notum et tonsoribus esse. Persius hic permagna negotia dives habebat Clazomenis, etiam litis cum Rege molestas, durus homo atque odio qui posset vincere Regem, confidens, tumidus, adeo sermonis amari, Sisennas, Barros ut equis praecurreret albis.
}

241 Conform DuQuesnay (1984, 37): “This creates the overwhelming impression that the friendship of Maecenas has imposed no inhibitions on Horace about freely recalling his earlier allegiance. The implicit message must have been reassuring to other former Republicans who had either just returned to Italy or who were still hoping to return after the defeat of Sex. Pompeius. If Horace, the freedman's son, could find such complete acceptance, there was hope for the others." 
(How the malicious and virulent Rupilius Rex, that outlaw, was repaid by the half-breed Persius is well-known, I think, to all blear-eyed men and barbers. This Persius was a rich man and had a very large business at Clazomenae and also an intractable lawsuit with Rex. Persius was a hard man, who could outdo Rex in offensive conduct, overconfident, arrogant, and so sharp-tongued that he would beat by a long shot the Sisennas or Barruses) $)^{242}$

The ex-praetor Rupilius Rex came from Praeneste (see line 28) and joined Brutus in Asia after he was proscribed in the triumviral proscriptions of 43 B.C. by Octavian to raise the necessary cash for recruiting the legions against Brutus. ${ }^{243}$ Cicero in Fam. 13.9.2 refers positively to a P.Rupilius P.f. Men., qui est magister in ea societate (P. Rupilius, son of P. from the tribe Menenia, who is the leader of this association [of tax-gatherers in Bithynia]). It is not certain whether this is the same man as the Rupilius in the present poem. Persius is not known, except that he owned a large business in the town of Clazomenae (modern Uria, region of Ionia, near Izmir, West Turkey). His name Persius suggests that his father was Roman and hybrida may mean that his mother was from Asia Minor, perhaps from Clazomenae. However, if the two men were fictitious the names may well have a different function. Indeed, it is likely that lines 2-3 opinor/ omnibus et lippis notum et tonsoribus esse (is well-known, I think, to all blear-eyed men and barbers) indicate that the story of the court case is Horace's fiction. Blear-eyed men are unreliable witnesses and during their visits to the "chemists" and those to the barber's shop they pick up much local gossip. Rex may be chosen in order to give Persius the opportunity to make his arrogant attack at the end, and the name of Persius, that also means "Persian" (see Gowers, 2012, 253), may well be a functional reference by Horace to the continuing Parthian influence in Asia Minor and the failure of Marc Antony to resolve the Parthian issue. I intend to demonstrate that Horace at several places indicates that this is the underlying meaning of this sermo. For example, I concur with van Rooy (1971, 74), who makes a case that hybrida in line 2 "alludes to high-minded and insulting hybris in the conduct of the half-Greek. That Horace attached a special meaning to 'hybrida' is suggested not only by the hyperbaton 'hybrida .... Persius', but by the emphatic position of the word at the beginning of the second verse. Moreover, 'hybrida' used adjectivally does not merely balance 'proscripti' at the beginning of vs.1.” The reading that Persius conducts himself with arrogance accords with mine, particularly with his charge at Brutus at the end of the sermo. Persius is a hard (durus) and sharp-tongued (sermonis amari) man who could not care less. ${ }^{244}$ The problem with Brutus is obviously that he does not possess sufficient moral authority to prevent those humiliating charges.

242 I owe several of the translations to Gowers (2012, 252-255).

243 For Rupilius Rex, see Gowers (2012, 252-253); Henderson (1994); Rooy, van (1971, 68); Rudd (2007, 64). For the proscriptions of 43 B.C., see Boatwright et al. (2004, 272).

244 Sisenna and Barrus are unknown, probably types; see Gowers (2012, 255). 
Next, Horace focuses in lines 9-21 on the dispute between Rex and Persius, without telling us what they differ about, comparing their conflict with the Trojan War, that was according to Herodotus book 1 the first armed conflict between East and West. I interpret this allusion to the Trojan War as another indication that Horace invokes the contemporary situation in 38 - 36/35 B.C. in the province of Asia. He gives the main line of his story in S.1.7.9-10 and S.1.7.18-21: I will discuss those lines first. ${ }^{245}$

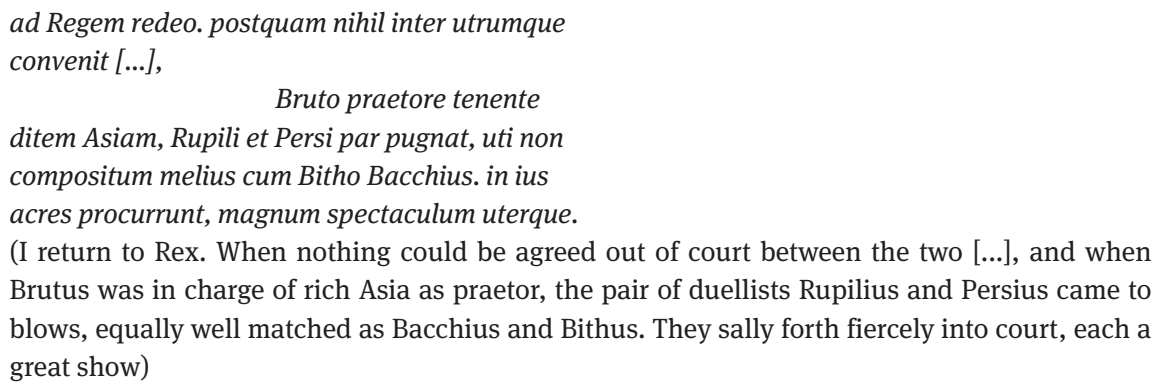

Horace calls Brutus somewhat inaccurately "praetor" in line 18, and I indicated above already that Brutus had assumed wider illegal powers of propraetor in ditem Asiam (rich Asia). The latter office gave him the opportunity to extract the money in the rich province that he required for raising an army. This is yet another parallel with Marc Antony's conduct in Egypt and Asia seven years later. ${ }^{246}$

Turning to the allusion to the Trojan War, the poet describes no mean quarrel between the two litigators. In line 11, they happen to be involved in head-on war (adversum bellum incidit) because they are brave fighters (fortes), who, like Hector and Achilles, could only fight it out till death would divide them (ut ultima divideret mors) (line 13). However, in lines 15-18 Horace describes the opposite when the Lycian ally of Troy, Glaucus of Iliad.6, gave the Greek hero Diomedes his golden armour for his bronze (muneribus missis), instead of fighting him. The poet alters the original story (IL.6.119-236) significantly, as Diomedes refused to fight Glaucus as their families were guest-friends. According to Gowers (2012, 257) Horace describes both as "cowards (cf. pigrior in line 18 and inertis in line 15) who resorted to bribery to avoid fighting. Nonetheless, Glaucus is something of a role model for H.[orace], conciliatory rather than antagonistic.” In addition to the interpretation of Gowers, I suggest that lines 15-18 contain also two characteristics by which Horace may refer to the contemporary situation. The first one is the contrast between East (Glaucus) and West (Diomedes). The second may reflect a Roman prejudice, that is that it is easy to strike a bargain with

245 OCT gives in line 9 regem instead of Regem. I follow a.o. Gowers (2012, 256), as Horace refers here of course to Rupilius.

246 Acc. to Gowers (2012, 258) Bacchius and Bithus are most likely a well-known pair of gladiators. 
the Asians. This could infer that Horace suggests that negotiations with the Parthians should start in order to solve the Parthian problem: a course that was followed by Octavian after 27 B.C.

The actual court case and Persius' final outburst is the last part of the poem in lines 22-35. It begins with: Persius exponit causam (Persius sets out his case). Then, the remainder of line 22-23 reads: ridetur ab omni/ conventu ("there's laughter throughout the assize") (translation by Brown, 2007, 71). Although Horace does not tell us why the audience laughs, I presume that there is some hilarity as listeners recognize Persius' servile grovelling for Brutus. I do not agree with Anderson's (1982, 80) explanation that the laughter shows "how Horace has employed the comic dispute between Rupilius Rex and Persius in order to present, among other things, some of his [Horace's] own literary ideas in polemic." Anderson argues that Persius' pun "as a last resort [in lines 33-35, see below] achieves more than he anticipated: the audience laughs at his enemy [Rex]. No doubt, the audience was laughing at both foes.” Anderson concludes from the laughter that Horace dramatizes a basic theme of his satiric disagreement with Lucilius, that is "that simple laughter achieves more than spiteful invective." Although I agree with the latter statement, I do not see that Horace intended to make this point in S.1.7. ${ }^{247}$ Firstly, the audience doesn't laugh when Persius makes his final impertinent remark, but laughs much earlier in the battle of words between the two foes. Secondly, Anderson's interpretation doesn't take into account both the context of lines 22-26, where Persius exhibits his flatteries, and the context of the poem as a whole, in which Horace shows the dismal state of Brutus' propraetorship. S.1.7.23-26 reads:

laudat Brutum laudatque cohortem: solem Asiae Brutum appellat, stellasque salubris

appellat comites, excepto Rege; canem illum invisum agricolis sidus venisse.

(he [Persius] praises Brutus and he praises his staff. He calls Brutus the "sun of Asia," and his aides "auspicious stars," with the exception of Rex; he said that he had come like the Dog-star, hostile to farmers)

These lines by Persius are a fine example of flattery appropriate to a king. He cannot stop as we read in lines 26-27: ruebat/ flumen ut hibernum fertur quo rara securis (he rushed on like a river in winter, to which an axe is seldom brought). The simile refers to the wild torrent uprooting trees and thus making an axe superfluous; in other words, Persius went on and on paying his "respect" to Brutus, whose co-operation in settling the case in his favour he badly needed.

247 Anderson (1982, 80-81) makes the same point w. r. t. the last line of S.1.8. I will present my view that I also do not concur with his point w.r.t. S.1.8.50 when I discuss the latter line below. 
Then, it is the turn of the man of Praeneste, Rupilius Rex, to set forth his case in lines 28-31:

\begin{abstract}
tum Praenestinus salso multoque fluenti expressa arbusto regerit convicia, durus vindemiator et invictus, cui saepe viator cessisset magna compellans voce cuculum.

(Then, in answer to his [Persius'] outpouring of wit, the man of Praeneste hurls back violent abuse pressed from the vineyard, like a vinedresser, tough and invincible, to whom the passer-by would often have yielded when he loudly called "cuckoo.”)
\end{abstract}

Although Rupilius' identity cannot be established with certainty, lines 24-26 and 28-31 may provide some clues. Horace writes in lines 24-25 that Persius calls Brutus' aides "auspicious stars," with the exception of Rex (stellasque salubris/ appellat comites, excepto Rege). Thus, Rupilius is a close associate of Brutus, one of the propraetor's officials, one of the tax-gatherers. We also read in the lines about Rupilius' reply (S.1.7.28-31) that he is likened to a tough and invincible pruner of vines (durus/ vindemiator et invictus). This can also refer to Rupilius Rex being a tax official on the staff of Brutus, in particular responsible for collecting tax with farmers, as Horace writes in lines 25-26 that Rex had come like the Dog-star, hostile to farmers (excepto Rege; canem illum/ invisum agricolis sidus venisse). Penniless Rupilius, who was proscribed in 43 B.C., had sought safety in flight to rich Asia where he joined Brutus. Many of the men like Rupilius were tax-gatherers who were expected to raise an agreed amount of money and who could keep the surplus which they managed to extort; in other words, most of them were known to line their own pockets, often with considerable amounts. The reference to a tough and invincible pruner who cuts away excrescent growth may fit the image of the tough tax official who demands excessive taxes of a businessman, who is then forced to have his income cut to an absurd minimum, knowing that he cannot win. The reference to the cuckoo also fits this image. If according to PLIN.Nat.18.249 the pruning of the vines was not done before spring, the farmer was sneered at by passers-by who imitated the cry of the cuckoo. ${ }^{248}$ The relevance of Horace referring to this rural Italian habit in connection with a tax official may be the deliberate slowness with which the latter was used to do his work. The cause of those delaying tactics may have been the number of cases the

248 Conform Gowers (2012, 260). The text of PLIN.Nat.18.249 is: In hoc temporis intervallo XV diebus primis agricolae rapienda sunt quibus peragendis ante aequinoctium non suffecerit, dum sciat inde natam exprobrationem foedam putantium vites per imitationem cantus alitis temporariae, quam cuculum vocant (Meanwhile, in the period of the first fifteen days, the farmer must hurry with the work that he did not finish before the spring equinox; he knows indeed that from that time the base reproach to those who are still pruning their vines comes by someone imitating the cry of a bird of the season called the cuckoo). 
official took on in order to maximize his results, or, which is more likely, that the tax collector took his time to put his victims under pressure.

Thus, in my interpretation, Rupilius Rex is a tax official and Persius is one of his victims (either both in real life or fictitious). The court case is about a tax issue, presumably an assessment of Persius by Rex for such an absurd amount that it pruned away the profits of the trader Persius.

The final lines of the poem are often seen as a pun or joke (see note 240), but I intend to show that S.1.7.32-35 is meant to reinforce the message of the poem as a whole. I will explain this message below when I summarize the poem. Lines 32-35, Persius' final outburst, read:

at Graecus, postquam est Italo perfusus aceto,

Persius exclamat 'per magnos, Brute, deos te

oro, qui reges consueris tollere, cur non

hunc Regem iugulas? operum hoc, mihi crede, tuorum est.'

(And the Greek Persius, after his soaking with Italian vinegar, cries out "By the great gods, Brutus, I beg you, who makes a habit of removing kings, why not cut the throat of this Rex? Believe me, this job is just yours.”)

Persius, who sees that he has no chance against the combined forces of Rupilius and Brutus, has the last word in the poem. His impertinent outcry looks like a desperate request to punish Rupilius, but is as much a personal attack on Brutus referring both to his part in the murder of Julius Caesar and to the role of his ancestor L. Junius Brutus who sent Tarquinius Superbus into exile in 510 B.C. Horace, however, does not mention what one would like to learn, that is the judgement that Brutus passes. The latter remains as aloof until the end as he was right away from the start of the poem. It seems to me that Horace depicts Brutus, with his pretensions of an Eastern king, not only as not in control of the process in the court allowing Persius' ingratiation, abuse and final personal attack, but also as condoning the actions of Rupilius. Brutus is not only incompetent in upholding the dignity and authority of the Roman imperium, but also collaborates with evil forces, such as the men who fill their pockets by extortion.

I concur with Gowers' (2012, 251-252) point that Horace raises in the present poem contemporary political issues of great importance, although I differ from her view with respect to Horace's intention writing S.1.7. She (2012, 251) argues that Horace "takes the bold step of exposing Octavian's Achilles heel, the fact that he was heir to a rex," and she poses the question: "Is he [Horace] really able to deflect his readers from the new [Octavian's] tyranny staring them in the face by looking backwards to Brutus, not just the scapegoat but also the republican conscience of Rome." I interpret the poem differently, namely that Horace shows his concern about the instability of the political situation in 36 B.C., and the urgent necessity of strong leadership that Octavian may provide. I will explain this interpretation in the following paragraph.

In summary, one key figure in the poem is M. Brutus, who had usurped the office of propraetor, provincial governor with maius imperium, that also "covers his judicial 
function in the scene [of the sermo]" (Gowers, 2012, 258). He set himself up as an Eastern rex considering the flattery of Persius in lines 23-25. ${ }^{249}$ The other key figures are Persius and Rupilius Rex who had come to Brutus' court on account of a dispute about taxes. Horace depicts a scene from the past with Brutus presiding over a court session in which the arguments are exchanged in an aggressive manner and in which eventually Persius, one of the litigants, suggests that Brutus settles the matter in a way he was used to: by murdering Rupilius Rex. This humiliating scene was the result of Brutus' incompetence: seen to be enjoying the sumptuous life of the Eastern court, but not commanding the respect that a Roman official deserves. Brutus was removed at Philippi in 42 B.C., but Horace reminds his audience in this poem six years later (in 38 - 36/35 B.C.) that it's the same old story over again of a Roman official who lives at the court in Alexandria and whose military and administrative achievements are minimal: Marc Antony's fiasco in Parthia and his submission to Cleopatra's ambitions of their own imperium in the East are a threat to Rome. ${ }^{250}$ Further, the enrichment by many officials still prevails in Asia, and nothing is done about it. I suggest that Horace transmits in S.1.7 an implicit message to Maecenas that is meant to show that he supports the political agenda of Octavian, that is that Marc Antony ought to be removed having mismanaged his military and political responsibilities. Horace will return to those issues in the next sermo.

Horace returns in $\mathbf{S . 1 . 8}$ to contemporary events. ${ }^{251}$ He presents in the opening lines the god Priapus, whose statue stands in an old burial ground for the poor on the Esquiline, which was turned into beautiful gardens by Maecenas as part of Octavian's programme of improving many places in Rome. More about these grounds later. S.1.8.1-7 reads:

OLIM truncus eram ficulnus, inutile lignum, cum faber, incertus scamnum faceretne Priapum, maluit esse deum. deus inde ego, furum aviumque maxima formido; nam fures dextra coercet obscenoque ruber porrectus ab inguine palus; ast importunas volucres in vertice harundo terret fixa vetatque novis considere in hortis.

(Once I was a trunk of a fig-tree, a useless piece of wood, when a carpenter, uncertain whether he should make a stool or a Priapus, chose rather that I should be a god. Since, I am a god, the

249 For Brutus' office in Asia, see also DuQuesnay (1984, 37); Gowers (2012, 250; 257).

250 My interpretation of $S .1 .7$ is contrary to Buchheit (1968), who interprets the poem as a piece of literary criticism.

251 For S.1.8., see Anderson (1982, 74-83); Brown (2007, 169-174); DuQuesnay (1984, 38-39); Gowers (2012, 263-280); Oliensis (1998, 68-70; 72-74); Welch (2001). Tupet (2009, 284-329) gives an extensive outline of Horace and magic in S.1.8. For the strong connection between S.1.8 and Callimachus's Iambs 7 and 9, see Freudenburg (1993, 105-106). 
greatest fright for thieves and birds; for thieves are controlled by my right hand and by the red pale extending obscenely from my loins; while the reed stuck to the top of my head frightens the troublesome birds and keeps them from settling down in the new gardens)

Gowers $(2012,266)$ observes that "Priapus' new lease of life [from trunk to god] after unpromising beginnings epitomizes not just the reinvigoration of the graveyard and Rome as a whole under Octavian [...], but also H.[orace]'s own salvaged fortunes after the dead end of Philippi." With respect to S.1.8, I will argue that the poem, like the previous one, shows indeed Horace's confidence after the salvage of his fortunes. I observed already in the introduction to this section (2.2.4) that in S.1.7 and S.1.8 Horace chooses as his subjects for discussion contemporary major issues. He does this presumably in order to demonstrate that he also has a contribution to make in those fields and again to show that he supports the policies of Octavian and Maecenas. I intend to demonstrate that the major issues are not only about revitalising Rome, but also, and in my view primarily, about issues like the threat of foreign mores to Roman society. Magic had not only spread among Rome's lower classes, but according to Watson $(2003,181)$ "one of the most striking things about magic at Rome was the degree of penetration which it had attained among the upper classes."252 Anderson (1982, 75) observes that "the events of Horace's 'anecdote' [in S.1.8] do not arouse much critical interest" and that commentators have not dealt with the poem in its own right, but treated it as anomalous to the other poems in S.1. Anderson sees S.1.8 as carefully composed "with qualities analogous to those of the other Satires in Book I." In my view, an analysis of the poem within the functional frame will reveal that it is much more than a narrative about gardens, a minor deity and witches, and that Horace discusses indeed major issues. But, let us first consider Priapus' roles in this.

Priapus, originally a fertility god from Lampsacus (modern Lapseki, opposite Gallipoli) in the Hellespont, became the name-giver of the "Priapic model," an image for Roman sexual humour. According to Richlin $(1992,58)$ "the general stance of this figure is that of a threatening male. He is anxious to defend himself by adducing his strength, virility, and (in general) all traits that are considered normal.” His exposed and erect phallus described in line 5 is his chief traditional weapon (see Gowers, 2012, 268-269). I will return to the significance of this characteristic when I discuss the finale of the poem, where Priapus manages to frighten off undesirable visitors without using his traditional weapon. According to Uden $(2007,198)$, Priapus' customary position was as a guardian of either vegetable and flower gardens or of tombs. ${ }^{253}$ For the first time Priapus has been installed in an elite pleasure garden. He has here also another, new role and that is that of Horace's spokesman/commentator in one of his sermones,

252 For Priapus, see Eitrem (1942, 63-67); Richlin (1992); Uden (2007; 2010). For magic in Rome, see Liebeschuetz (1979, 126-139); Tupet (2009); Watson (2003, 176-182) in his commentary on Epod.5.

253 For Priapus as the image for Roman sexual humour, see Richlin (1992, 57-65; 116-127). 
in addition to, as we will see later, that of expelling evil forces, like witches. I concur with what Zetzel $(1980,61)$ writes about the role of Priapus, namely "as a literary fiction in the context of the book." I hope to demonstrate at the end of the discussion of S.1.8 that by his choice for Priapus as spokesman Horace connects the events described in the poem with Cleopatra and Marc Antony.

Priapus describes his new environment in lines 8-16. First, he tells us of the history of the site on the Esquiline, which was originally a cemetery for slaves and paupers. The corpse of a slave used to be brought there from their narrow cells (angustis cellis) in a cheap coffin (vili in arca), arranged by (locabat) a fellow-slave (conservus) (lines 8-9). Next, Priapus also mentions in lines 10-11 that the site served as (stabat) a communal grave (commune sepulcrum) for the poor masses (miserae plebi), and for men like the jester Pantolabus and spendthrift Nomentanus (Pantolabo scurrae Nomentanoque nepoti). ${ }^{254}$ Horace shows in line 11 his familiar poor opinion of parasites and spendthrift new rich, who finish up in the gutter and are buried in a cemetery like this. The size of the plot is given in S.1.8.12: mille pedes in fronte, trecentos in agrum (thousand feet in frontage, and three hundred in depth) makes twenty six thousand square metres $\left(=2,6\right.$ ha.). ${ }^{25}$ This line and the next one are a piece of Horatian irony. He writes that the plot has a cippus (pillar) that gave to understand that the monument was not to be passed to heirs (dabat: heredes monumentum ne sequeretur): a mass grave as a bequest. But, the line precedes nicely the description of the new plot which Maecenas will bequeath to the citizens of Rome. Lines 14-16 read:

nunc licet Esquiliis habitare salubribus atque

aggere in aprico spatiari, quo modo tristes

albis informem spectabant ossibus agrum;

(Today people may live on a wholesome Esquiline and stroll on the sunny mound, from which recently they had a gloomy view of a plot disfigured with white bones) ${ }^{256}$

The cleaning-up measures of the old site on the Esquiline were part of the rebuilding and modernizing of Rome by the new regime that was started in 36 B.C. by Octavian and his supporters, among them Maecenas and Agrippa, and to be paid for by the planned military campaigns in the East. The programme held not only the erection of new buildings, but also, as Appian in Bellum civile.5.132 (= V.547) mentions, the slaughter of thieves and robbers in 36 B.C. by Sabinus, and Agrippa's expulsion of astrologers and witches from Rome in 33 B.C. Agrippa's activities were described by Cassius Dio (49.43.1 and 49.43.5). ${ }^{257}$ Thus, Priapus discovers that his task is not to

254 According to Gowers (2012, 270), Pantolabus (“Grab-all”) is "a 'typical' comic parasite’s name.” For Nomentanus, whom also figured in S.1.1.102, see note 80.

255 For the calculation of the area I am indebted to Gowers (2012, 270).

256 For the rendering of lines 15 -16, I followed the suggestions of Gowers (2012, 272).

257 For the programme of modernizing Rome and the expelling of witchcraft, see DuQuesnay (1984, 
chase away thieves and animals, or to have a chat with promenaders in the pleasant new surroundings, but to remove witches, who have taken over the site. It turns out to be a thankless task. He says in lines 17-22:

\begin{abstract}
cum mihi non tantum furesque feraeque suetae hunc vexare locum curae sunt atque labori, quantum carminibus quae versant atque venenis humanos animos: has nullo perdere possum nec prohibere modo, simul ac vaga luna decorum protulit os, quin ossa legant herbasque nocentis. (whereas for me thieves and wild beasts used to disturb this place do not cause me as much care and pain, as those witches who manipulate with spells and love potions human souls: no way I can destroy them or prevent them from collecting bones and harmful herbs, as soon as the wandering moon has brought out her beautiful face)
\end{abstract}

Priapus recognized the witches; they are repulsive Canidia and her companion. ${ }^{258}$ In lines 23-26, we learn that Priapus saw them with his own eyes (vidi egomet), and he describes the witches in great detail. Canidia walks around with her black cloak tucked up (nigra succinctam palla), barefooted (pedibus nudis) and with her hair unloosened (passoque capillo) filling the place with shrieks (ululantem) together with

38-39); Gowers (2012, 264; 271); Watson (2003, 179-180; 2007, 101). Sabinus is perhaps C. Calvisius Sabinus (consul in 39 B.C.). Appian in Bellum civile. 5.132 (= V.547 at Étienne-Duplessis, 2013, 110)

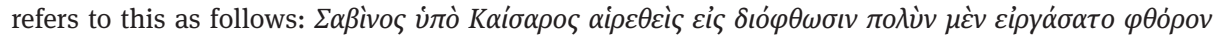

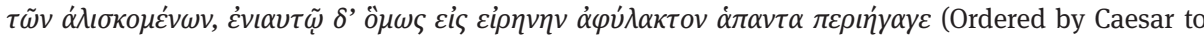
redress the situation Sabinus made a great slaughter of the captured [outlaws], but nevertheless he brought back everywhere peace and quietude). Cassius Dio described Agrippa's activities as follows

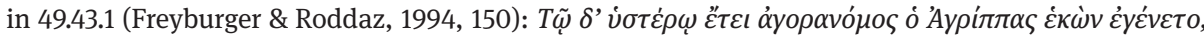

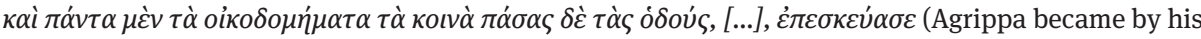
own choice aedile in the next year, and he repaired all public buildings and all roads) and in 49.43 .5

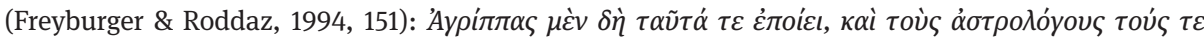

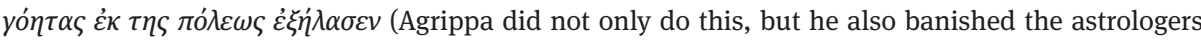
and sorcerers from Rome).

258 For Canidia, see Gowers (2012, 273-274); Tupet (2009); see also Henderson (1987, 111; 116); Oliensis (1998, 68-90). Contrary to Gowers (2012, 273), who approvingly quotes Oliensis $(1998,77)$ that Canidia "exercises sexual control over H.[orace] [...]. Specifically political interpretations may limit what is at heart a sexual battle between female overheatedness and male debility, two spheres which might be merged in the concept of 'male hysteria under political pressure'.” I will argue below, when I summarize the significance of Epod.17 for S.1.8, against the view that Horace had a sexual relationship with Canidia. Gowers and Oliensis miss Horace's use of the first-person persona in Epod.17. In my view, there is much value in Mankin's $(2010,100)$ suggestion for the name of Canidia: “her [Canidia's] name seems to point to two associations, with the 'dog' (canis) and the furiously 'dogged' genre of iambus (conform Ep[od].6), and with 'old-age' (canities) and the decrepit impotence not only of the poet, but of Rome as it collapses into ruin (Ep[od].16,1-2) under the weight of its ancient curse (Ep[od].7,17-20)." (italics are mine). 
her companion Sagana, who is bigger than she (Sagana maiore). Their pallor is a dreadful sight (pallor utrasque/ fecerat horrendas aspectu).

Then, poor Priapus sees them engaged in those horrible witches' activities, which fill nearly half the poem in lines 26-45. Apparently, Horace wants to impress upon us the terrible wickedness and dangers of black magic. Through the medium of Priapus, he depicts in those lines a scene that could be seen at many places in Rome and in Italy. I will explain below in detail the poet's reason for using the "persona" of Priapus. The latter is a functional reference to Cleopatra and Antony. Horace himself does not feature in the poem, as he wants to get it absolutely clear that he never experienced such a séance, but that he retells what he learned from others. Thus, what Priapus describes in S.1.8.26-45 are the witnesses' tales of the customary forms of black art, such as necromancy and psychedelic experience. Oliensis (1998, 69 note 9) points out that the psychedelic scene of lines 34-35 is "commonplace" black magic "modelled on Jason's supplication of Hecate in Apollonius Rhodius' Argonautica 3.1214-1217" suggesting that those kind of hallucinations have their origin in Eastern witch-rituals. The story starts with necromancy in S.1.8.26-29:

\footnotetext{
scalpere terram

unguibus et pullam divellere mordicus agnam

coeperunt; cruor in fossam confusus, ut inde

manis elicerent, animas responsa daturas.

(they began to scrape the ground with their nails and to tear in pieces a black lamb with their teeth; its blood was poured into a trench, that from there they could conjure up the ghosts, souls that would give them answers)
}

Priapus also alludes to maenadic behaviour (mordicus) in S.1.8.27. Then, he describes in the scene of the two dolls both Canidia's efforts to win over by magic a lover and the psychedelic trance. S.1.8.30-36 reads:

\begin{abstract}
lanea et effigies erat, altera cerea: maior
lanea, quae poenis compesceret inferiorem;

cerea suppliciter stabat servilibus ut quae

iam peritura modis. Hecaten vocat altera, saevam

altera Tisiphonen; serpentis atque videres

infernas errare canis, Lunamque rubentem

ne foret his testis post magna latere sepulcra.

(there was one image of wool, and another of wax; the woollen one was larger, which could crush the smaller one by its punishments; the waxen one stood in supplication like a figure about to die in the manner of a slave. One witch called on Hecate, the other on savage Tisiphone; one could see serpents and bitches from Hell straying about, and the blushing Moon hiding behind the tall tombs, that she might not witness such deeds) $)^{259}$
\end{abstract}

259 I owe the rendering of S.1.8.32-33 (suppliciter........modis) to Gowers $(2012,275)$. 
In the "ritual puppet-show" (Oliensis, 1998, 70) of lines 30-33, Priapus sees two images, one of wool and one of wax. The significance of the wool is that it can protect by warding away evil spirits and that of the wax is that the lover can be punished by melting the wax in the flame, also causing the melting of his heart. The larger woollen one stands for Canidia, who aims to win over a reluctant beloved by magic. The smaller waxen one represents the lover, who is dominated by the superior Canidia. The waxen image returns in lines 43-44 when Priapus sees that the fire blazed higher from the waxen image (et imagine cerea/ largior arserit ignis). The ritual described does not necessarily refer to Canidia and her reluctant lover, but can also depict her act for a customer of her magic. Contrary to Gowers (2012, 275-276), I interpret the scene of the two dolls (S.1.8.30-33) as Horace's description of black magic that was a core business of witches aimed at winning over a reluctant lover for which they were handsomely paid. I do not see that Priapus witnesses in those lines "a 'ritual puppet show' with voodoo dolls, one administering punishment, the other supplicating, which anticipates the conflict between H.[orace] and Canidia in Epod.17" (Gowers, 2012, 275). In the meantime, Hecate, the goddess of witchcraft, and Tisiphone, one of the Furies, are invoked. The psychedelic experience can be recognized in the description of the ghastly creatures like serpents and female hellhounds roaming around frightening the modest moon so much that she hides behind the tombs avoiding the obscene sight. Presumably, the moon does not blush primarily out of modesty, but out of anxiety when she, in a right-thinking mind because she cannot be brought into trance, encounters such harrowing witchery.

Next, Priapus swears to the verity of his story in lines 37-39 imagining his most dreaded fate. The scarecrow Priapus fears that crows befoul his head with their excrements (merdis caput inquiner albis/ corvorum), and the guardian of the site Priapus is afraid that the boy Julius, or cissy (fragilis) Pediatia or the thief (fur) Voranus piss and shit on him (mictum atque cacatum/Iulius et fragilis Pediatia furque Voranus). Because there is a limit to everything for Priapus, he decides in line 40 to cut a long story short (singula quid memorem) and he quickly finishes his story in S.1.8.40-45:

\section{quo pacto alterna loquentes}

umbrae cum Sagana resonarent triste et acutum, utque lupi barbam variae cum dente colubrae abdiderint furtim terris, et imagine cerea largior arserit ignis, et ut non testis inultus horruerim voces Furiarum et facta duarum?

(how the shades, speaking in turn with Sagana, gave back a sad, shrill sound, how they [the witches] furtively concealed a wolf's beard and the tooth of a spotted snake in the ground, how 
the fire blazed higher from the waxen image, and how as a witness I shuddered with fright at the words and deeds of the two Furies, although I did not go unavenged? $)^{260}$

Priapus did indeed not enter into a detailed description of the horrible acts of black magic. The two Furies, Canidia and Sagana, spoke with the ghosts they conjured up in lines 28-29, who answered them with sad sounds suggesting that they were not happy souls. Priapus does not tell us what he heard and saw. The wolf's beard and the snake's tooth are the witches' precautions against counterspells. Line 45, when Horace tells us about Priapus' fear and which introduces the final peak of the events, evokes Priapus' fear caused by the psychedelic scene that he just witnessed. We will see in the last five lines of the poem that Priapus gets into a state where he no longer can control his bodily functions. I will return to this point when I discuss S.1.8.4650. In addition, the foul scene produces not only Priapus' fear, but also radiates a sense of degeneration. Horace wants to indicate that those meetings are out of place in modern civilized Rome, the centre of the world. It is feasible that such stories of degenerate sessions are the result of anti-Egyptian and anti-Eastern propaganda, and that the reality was much healthier. In the latter case, the plans for development of the Esquiline conform to Horace's picture of the future city.

Before discussing the finale of S.1.8, I will first present my understanding of Horace's views on witchcraft as expressed in the poem. Therefore, it is useful at this stage to chart related texts in which he examines the subject. At the time, witchcraft was a very topical issue that concerned the new regime for several reasons. The leadership's unease was not only about the "traditional" black magic and the crime it attracted, ranging from theft and dealing in magic drugs and potions to murder, but also about the resulting sexual debaucheries. In addition, there was apprehension about the foreign influence on Roman society, particularly among the upper classes, of which many were attracted by Cleopatra and Egyptian culture (see also note 252). Horace subscribes to this concern, which is apparent from the fact that, apart from pointing out or alluding to the dangers of black magic in several poems, he mentions Canidia by name not only in S.1.8, but also in S.2.1 and S.2.8, and in Epod.3, Epod.5 and Epod.17, which is saying a good deal. In the last lines of S.2.8 - closing the books of Sermones - he repeats his view on the hazards of sorcery, when he writes velut illis/ Canidia adflasset peior serpentibus Afris (as if Canidia breathed on those, worse than African serpents); he considers Canidia and her black art more dangerous than African serpents, the most menacing of their sort.

In order to gain more insight in Horace's attitude to the dangers of black magic, a poem which he wrote in the same period (38 - 30 B.C.) as S.1.8, should be considered here, namely Epod.17. ${ }^{261}$ The epodos is particularly important as Horace continues

260 In S.1.8.41, I follow Gowers $(2012,277)$ with resonarint instead of resonarent in OCT.

261 Epod.17.1-7 is an echo of the boy's words in Epod.5.1-10. Both opening passages are a plea for 
in this poem his story of S.1.8. Consequently, if S.1.8 is read together with Epod.17, significant indications about the meaning of S.1.8. can be found, as the epodos contains many echoes of the sermo. Epod.17 refers back to S.1.8 in several ways. Epod.17.8-18 is a catalogue of Canidia's activities on the Esquiline. Epod.17.8-10 alludes to magic healing. Epod.17.11-14 describes Hector's body given up to birds of prey and wild dogs (addictum feris/ alitibus atque canibus) alluding again to Canidia's activity on the funeral site at the Esquiline. Epod.17.15-18 depicts how the arch-witch Circe permitted Odysseus' men to have their mind and voice returned (mens et sonus/ relapsus) alluding to a psychedelic experience by Odysseus' comrades. ${ }^{262} \mathrm{Next}$, Horace refers back to S.1.8, when Canidia says to him in Epod.17.56-59:

inultus ut tu riseris Cotyttia

vulgata, sacrum liberi Cupidinis,

et Esquilini pontifex venefici

impune ut Vrbem nomine impleris meo?

(will you be unrevenged for ridiculing Cotytto's festival that you made known to all, the sacred act of free Love, and will you, the high priest of magic Esquiline, be without fear of punishment for filling Rome with my name?)

These lines give Canidia's reply to Horace's appeal that she stops tormenting, but they also refer to Priapus' words in S.1.8. Epod.17.56 is an echo of the words of Priapus in S.1.8. 44-45 when he said et ut non testis inultus/ horruerim voces Furiarum et facta duarum (and how as a witness I shuddered with fright at the words and deeds of the two Furies, although I did not go unavenged). Further, Canidia mentions in the above passage that she celebrated Cotytto's festival at the Esquiline, a deity of Thracian origin related to Artemis-Bendis, whose rites were secret licentious activities "characterized by extreme wantonness” (Watson, 2003, 573). ${ }^{263}$ However, according to Watson (2003, 573) "it seems unlikely that the goddess was ever worshipped in Rome, which may account for the unusual account given by Horace." In my opinion, Epod.17 and S.1.8 can also be understood that Cotytto was indeed worshipped in Rome, but that Horace gives a fictitious story in both poems. Other references to Greek mythical sorcerers and sorceresses in Epod.17 are also relevant to our understanding of S.1.8, as those relate to what Horace regards as Eastern barbarism threatening traditional Roman values. $^{264}$ We find Telephus, Circe, Nessus' blood, and others. ${ }^{265}$

mercy to Canidia and in both the word per is repeated three times invoking gods and books (libros) in the former and gods and children (liberos) in the latter passage. Conform Mankin (1995, 274).

262 For the passages from Epod.17, see also Mankin (1995, 275-278). For Circe, see Tupet (2009).

263 For Cotyttia, see Watson (2003, 572-573).

264 For the Eastern origins of magic, see Liebeschuetz (1979, 130-133).

265 Lowrie (2009a, 108-110) discusses Epod.17 from a different perspective, that is "what poetry can and cannot do" to change Canidia's reputation, i.e. the power of poetry over magic. This subject is rather far removed from my focus. 
So far the examination of Epod.17 as a sequel to S.1.8. A second issue that needs our attention is that of Horace speaking directly in Epod.17 - in the first person singular - to Canidia pleading that she stops tormenting him with her magic. It seems that, in the words of Mankin (1995, 278), Horace recites in Epod.17 "his sufferings, admits his fault in doubting Canidia's power, and asks how he can end his torment." Words like dedi satis superque poenarum tibi (I have suffered enough and more than enough punishment by you) in Epod.17.19, and the examples of the physical and mental effects of his suffering, such as in Epod.17.21 fugit iuventas et verecundus color (my youth and modest complexion have disappeared), nullum ab labore me reclinat otium (no peace releases me from my suffering) in line 24, and other lines suggest that Horace refers to himself. Next, Horace bewails in a long passage, Epod.17.27-52, the lack of prospect of better times, and asks what he must do to make her stop torturing him; he says in line 45: et tu, potes nam, solve me dementia (and you, because you can do it, set me free from my madness). Towards the end of this passage, he attempts to coax Canidia into ceasing her evil actions. For example, in lines 47-48 he refers back again to the scene on the Esquiline, promising that he could say that she is not the kind of old woman who cleverly disturbs the recently buried ashes in the graves of the poor (neque in sepulcris pauperum prudens anus/ novendialis dissipare pulveres), while we know from S.1.8 that this is precisely what she did. Canidia's triumphant reply in Epod.17.53-81 seems to suggest that Horace is the loser in the confrontations with the sorceress: her black art will win. But the final line, Epod.17.81, throws a different light on this. Canidia asks the rhetorical question plorem artis in te nil agentis exitus? (should I weep over the results of my art since it has no effect on you?). Horace says by means of Canidia's words that her art does not accomplish anything against him, thus that he is not a loser but that she may come off the loser.

Thus, Horace imagines in Epod.17 his final confrontation with Canidia; it is final as she does not return in his poetry after S.2.8 and Epod.17. He wrote the epodos in the first person and although he seems obsessed by the power of Canidia's magic, I assert that he did not intend to intimate that he personally suffered by her magic. I mentioned already in section 1.3.1 (“Autobiography in Horace's poetry") his use of the first-person persona in Epod.17 by which Horace does not relate real-life experiences with the evil witch, but uses the form of the first-person persona as a functional reference to the generally known activities of witches and the destructive consequences of their art to Roman society.

This also relates to the questions, discussed by several scholars, whether Horace either was perhaps Canidia's lover, or at least participated in the witches' sessions of wild love-making to an unknown woman, not Canidia. ${ }^{266}$ Concerning the first question whether Horace was Canidia's lover, Mankin (1995, 277) states that in Epod.17.15-18

266 For the relationship between Horace and Canidia and a broader exposé of Horace's misogyny, see Oliensis (1998, 68-90). 
"H.[orace] may be implying that he has slept with Canidia." I will explain below that I concur with the contrary view as expressed by Watson $(2003,534)$ that "it has become almost an article of faith that the agonies which the poet describes so graphically in Epode 17 are the pangs of love [...]. This is a misconception. Nowhere in the Epode is there any suggestion that Canidia desires Horace to fall in love with her." Concerning the second question that Horace participated in a witches' session, we saw that Canidia indeed refers in Epod.17.58 to him as the high priest of magic Esquiline, which may suggest that he was a participant in rather than an observer of the events on the Esquiline. In his commentary on line 58, Watson (2003, 573-574) states that the words Esquilini pontifex venefici

may be understood in two ways, of which the first seems superior: (1) far from being merely, as he would have us believe, an observer of the magical ceremonies on the Esquiline, Horace is a participant, in fact their leading spirit (pontifex), an impertinent and outrageous accusation, but one to which knowledgeable opponents of magic have always been liable. (2) [...]: in condemning Canidia's magic rites, Horace has improperly arrogated to himself one of the functions of the pontifices, [...] The first explanation seems preferable, as more linguistically straightforward.

I concur with Watson who does not interpret the events on the Esquiline as described in S.1.8 and Epod.17 as historic with Horace as participant, but who sees him as a "knowledgeable opponent of magic." ${ }^{267}$ However, I do not support the view of Oliensis (1998, 77) writing about Epod.17, who from a different perspective points at the misogyny of the Epodi "which attributes the decline of Rome to the sexual misconduct of Roman women. [...] But it would be a mistake to reduce the sexual epodes to allegories or moralizing diagnoses of the contemporary political scene. [...] Horace is not a detached analyst of current events but an enmeshed participant."268 Gowers (2012, 273), writing about S.1.8.24, states that "she is vilified for being repulsive, but exercises sexual control over H.[orace].”

Although issues of extreme wantonness in female and male sexuality are at stake in both S.1.8 and in what Oliensis calls the "sexual epodes," it is my opinion that several arguments of different nature can be raised against both the first view that Canidia "exercises sexual control over H.[orace]," and against the second view that the real Horace was an "enmeshed participant." With respect to the first view, I contend that the emphasis in Canidia's fictitious reply in Epod.17 is not that Horace was her lover, but on the damage he did in the fictitious story of $S .1 .8$ to her reputation of a

267 For the tendency of outrageously accusing opponents, see Watson $(2003,574)$ who refers to CIC. Sest.17.39 for evidence of "a comparable piece of malicious exaggeration." The text in pro Sestio relates to P. Clodius who, accused of spying upon the Bona Dea rites, was called by Cicero stuprorum sacerdos (a priest of debauchery). In the same line he was further characterized by Cicero as sororis adulter (his sister's lover), veneficus (sorcerer), testamentarius (forger of wills), sicarius (assassin) and latro (bandit). 268 For the immorality of Roman women as a cause of the evils of the Roman world, see Liebeschuetz (1979,92-94). 
sorceress. ${ }^{269}$ Concerning the view that Horace was a participant, I assert firstly that Canidia reproaches Horace that he ridiculed Cotytto's rites of free love, which also indicates that he was not a member of a party who revelled wantonly in those acts of free love. Secondly, there are no indications in Horace's other poems that he suffered the physical and mental effects of his putative active participation as described in Epod.17, such as sudden ageing (Epod.17.21): the reduced vitality described in line 21 exemplifies that of the victims of black magic in Rome and Italy in general. Nor are there indications that Horace did not find release from suffering (Epod.17.24) and that he suffered from a trauma (Epod.17.25-26), as he continued to have the peace of mind to work and write: the lack of respite and the trauma illustrate again in general the mental burden that the victims of the witches have to bear. Thirdly, Canidia tells Horace in Epod.17.53-81 that she will have her revenge in an incoherent outburst, that suggests that she suffered from a deranged mind, possibly under the influence of one of her potions. Horace implies by means of this reaction to his appeal that he was right to have made known to all her wicked sorcery by his disclosure of her imagined activities upon the Esquiline in S.1.8. The narration, of her real or fictitious activities symbolizes the dangers of the many real magic rites in Rome at the time. Finally, there is also no reason to suppose that Horace had knowledge of the excesses of magic rites in Rome as a result of personal participation; he could have learned about those from the discussions of the subject with his companions or simply from hearsay. It is reasonable to expect that the theme of S.1.8 and that of Epod.17 match the context of Horace's disquiet about the growing Eastern influence on matters of mental culture caused by, among other matters, the involvement of individuals in Eastern forms of witchcraft, for example those of Cotytto, a deity of Thracian origin.

In summary, the above evidence shows that Horace voices in Epod.17 the generally felt concern caused by the widespread sorcery that appeared to still be ongoing in Rome as if the measures taken seem to had no effect. Horace himself is not a participant in those sexual games, and it is feasible that his Canidia stories are poetic fiction. This is not to say that the kind of sessions described did not take place in Rome, but it is not unlikely that what we read is the result of hearsay. Horace suffers metaphorically and by substitution the mental and physical torments of the victims of sorcery, and I concur with Mankin's $(1995,273)$ statement that "this suggests that Epode 17, like the other Canidia poems, is another symbolic representation of the curse afflicting both individual and city."

Returning to $S .1 .8$, we left Priapus a few lines before the finale of the poem. The last lines have a great surprise in store for us. He tells in S.1.8.46-50, that he let a mighty fart with the noise of a bladder bursting, splitting his figwood bottom in two

269 For the emphasis in Canidia's reply, see also Watson (2003, 534): "Nowhere in the Epode is there any suggestion that Canidia desires Horace to fall in love with her: her intention rather is to take revenge upon him for mocking her publicly." 
(nam displosa sonat quantum vesica pepedi/ diffissa nate ficus), which produced the desired result. ${ }^{270}$ The witches ran off to the city (at illae currere in urbem), with Canidia losing her false teeth and Sagana her high wig (Canidiae dentis, altum Saganae caliendrum/ excidere) and both their herbs and enchanted love-knots (incantata vincula) falling from their arms (excidere lacertis). It made a very funny showpiece (cum magno risuque iocoque videres). The interpretations of the unusual method with which Priapus frightens the witches away differ considerably. In line 5, Priapus' erect phallus is presented as his chief weapon to frighten undesirable visitors, while in the end a fart brings about the witches' flight. I suggested above that Horace emphasizes in Priapus' words of S.1.8.40-45, which is the passage just before the "fart" passage, the deranged state of Priapus' mind and loss of control of his bodily functions due to his psychedelic experience. Letting off the fart demonstrates the loss of control. Anderson (1982, 79-81) argues that in S.1.8 the poisons of the witches "remind us of the poisonous invective of lampoons and the Lucilian tradition," and that Priapus after his fart "invites us to laugh at the comic discomfiture of the witches." In other words, Anderson says that the end of S.1.8 is like S.1.7.22 and S.1.7.33-35 (see also note 247), about which he concluded earlier that it appears from the laughter that Horace dramatizes a basic theme of his satiric disagreement with Lucilius, that is "that simple laughter achieves more than spiteful invective." It seems to me that it is unlikely that S.1.8 is aimed at Lucilius. First, the phallus is specifically connected with the Priapic tradition and not with Lucilius, and farting is a "reversal of the traditional phallic one, but equally combative” (Hallett, 1981, 342; Gowers, 2012, 279). Second, as I will argue below, the context of the poem is the increased concern about black magic in Rome. I concur with Gowers' $(2012,279)$ statement that "the fart has the desired effect of sending the witches packing with a gesture of contempt."271 Priapus' fart and the laughter of line 50 not only symbolize Horace's contempt for witchcraft and witches, but also ridicule the witches. In addition, the passage expresses his scorn for the many in Rome and Italy who keep their perpetrators in their profitable business. I will argue below that Horace's objective was not to make a statement about Lucilian invective, but that in the present poem he focuses on serious contemporary political issues.

I have already mentioned in the discussion of the opening, that Horace connects the events described in the poem with Cleopatra and Marc Antony by his choice of Priapus as narrator of the story and Canidia as the chief culprit. Horace, like he did in S.1.7, introduces again the opposition East-West with the roles he gave those two. Although a functional reference generally applies to one person or one event only, this is slightly different in this case. Here I interpret Priapus as a functional reference to both Cleopatra and Marc Antony and their liaison. Priapus, the mythical son of Dionysus and Aphrodite, played an important role in the cult of Dionysus in Hellenistic

270 For Priapus' fart, see Gowers (2012, 278-279); Hallett (1981).

271 Italics are mine. 
Egypt. Aphrodite refers to Cleopatra, who had been introduced in Rome as equal to Isis/Aphrodite, when she joined Julius Caesar there in 46 B.C. as the queen of Egypt. Dionysus refers to Antony, who let himself be applauded as the New Dionysus during his campaigns in Asia. When Antony ordered Cleopatra to meet him in Tarsus in 41 B.C. to discuss her contribution to the war effort, she made a magnificent entry on board of her ship as Aphrodite/Venus, the ancestress of the Julian house whose statue was still in the temple of Venus Genetrix in Rome. Schäfer (2006, 125-128) points out that a Hellenistic statue was found in Pompeii of Venus leaning on a statuette of Priapus. ${ }^{272}$ Thus, the figure of Priapus in S.1.8 was easily recognized by the readers of the poem as referring to both Antony and Cleopatra. Plutarch (Ant.25, 1-2) writes about the meeting in Tarsus that an intelligent contemporary as Q. Dellius immediately saw the power of Cleopatra. ${ }^{273}$ He understood that she captured men not only by her beauty or by sexual attraction, but mostly by her intelligence paired with her determination to be queen of a powerful empire. During the meeting in Tarsus she floored Antony with a grandiose show of her luxurious taste, her intelligence and social skills. This was the start of a twelve-year relationship that lasted until their deaths in 30 B.C. In the winter of 41 B.C. Cleopatra brought Antony to Alexandria. Plinius the Elder in his Naturalis Historia (Nat.9, 119-121) described the extravagant feasts and meals at the queen's court, and Plutarch (Ant.28 and 29) does not omit to portray the Roman prejudices concerning the extravagance, waste and decadence of the court in Alexandria, as Antony indulged with enthusiasm in Cleopatra's favours. Increasingly Cleopatra took over control of political affairs. ${ }^{274}$ Plutarch (Ant.60.1) hints that Antony was dazed by (Cleopatra's?) narcotics, as he mentions that when Octavian decided in 32 B.C. to wage war against Cleopatra, he said "that Antony was not master of himself as he was under the influence of drugs (ì்̀ $\varphi \alpha \rho \mu \alpha \dot{\alpha} \omega v)$.” Plutarch (Ant.61,3-62,1) also writes that the territories in the East stood opposed to those in the West, and he leaves no doubt that Cleopatra was the leader.

We saw that Horace also alludes in Epod.17 to Eastern mythical sorcerers and sorceresses and to Cotytto's festival at the Esquiline, a deity of Thracian origin related to Artemis-Bendis, whose rites were secret licentious activities characterized by extreme wantonness. Thus, in this Sermo and in the last Epodos, both written a few

272 Statue of Venus in the Museo Nazionale di Napoli Inv. 152798; see also Schäfer (2006, 305 note 11). For Cleopatra and Marc Antony in Alexandria, see Schäfer (2006, 121-137); Weeda $(2010,108)$.

273 For Quintus Dellius, see HOR.Carm.2,3.

274 For Antony's luxurious life at Alexandria, see also Griffin (2004, 41); Schäfer (2006, 134-137; 185-187). My interpretation of S.1.8 as a highly political poem in which Horace reveals the increasing influence of Cleopatra on Antony in matters of strategic policy is contrary to the view of Griffin (1993, 7) who states that "to give this rather laboured squib [S.1.8] a political thrust, it must be argued that the poem 'deals with the transformation of the burial ground on the Esquiline into the magnificent horti of Maecenas', [quoting DuQuesnay, 1984, 38] 'reminding us of the benefit which Maecenas has conferred upon the city by ridding it of such nuisances'.” 
years before Actium, Horace writes about sorcery and alludes by means of Priapus to Cleopatra, who held sway over Antony and many Romans through Eastern sorcery and magic. Horace shows in S.1.8 and in Epod.17 that he considered sorcery and magic, that had penetrated both the lower and upper classes of Roman society more than was sound, to be dangerous for Rome. The connection with Cleopatra suggests the danger of all the dark eastern forces which could demolish Roman values, not just by sorcery but also by possible military and political action by Cleopatra and Antony. A substantial part of the Roman elite allied to the Egyptian queen and Antony would not be helpful in the event of a military action by the two. Added to this, at the time of writing of S.1.8 black magic was also associated with the followers of Sextus Pompey, as Pliny the Elder writes in PLIN.Nat.7.178. Tupet (2009, 328-329) recognizes that Horace's condemnation of magic is also a political statement. She $(2009,328)$ writes "Horace, en écrivant ces poèmes sur la magie, a donc servi la politique impériale. Mais on ne peut lui dénier une part de sincérité personelle (Therefore, Horace aided the imperial policy, when he wrote these poems about magic. But, one cannot deny him an element of personal frankness)." I interpret her words that she does not suggest that Horace wrote S.1.8 as part of Octavian's propaganda. I concur with her view because there are many indications that Horace came independently to his view about the dangers of magic, which happened to correspond with those of the political leadership. ${ }^{275}$

In conclusion, I will summarize first S.1.8, followed by a summary of both $S .1 .7$ and S.1.8 as Horace raises, apart from specific issues in each poem, in both the same strategic issues. Specifically, in S.1.8, Horace calls attention to the dangers of sorcery and magic not only for the mental and physical health of those who take part in it, but also for the growing Eastern influence sapping the fortitude of Rome. It is likely that he therefore also supported the formation by Maecenas of "some kind of precursor of the Vigiles, a sort of police force cum fire service” (DuQuesnay, 1984, 38), who could deal with the witches' activities. ${ }^{276}$ Most likely he supported Maecenas’ transformation

275 Part of PLIN.Nat.7.178 reads: bello Siculo Gabienus, Caesaris classium fortissimus, captus a Sexto Pompeio, iussu eius insica cervice [...], uti Pompeius ad se veniret aut aliquem ex arcanis mitteret; se enim ab inferis remissum habere quae nuntiaret. misit plures Pompeius ex amicis (During the Sicilian war, Gabienus, the bravest man of Caesar's fleet, was captured by Sextus Pompey, who ordered to cut his throat [...], that Pompey should come to him [Gabienus] or that he should send one of his trustworthy men; because he was sent back from the underworld with a message. Pompey sent a number of his friends). For Sextus Pompey and black magic, see also DuQuesnay (1984, 38-39); Liebeschuetz (1979, 119-139); Watson (2007, 101): “a push in the 30s by Octavian and his ministers to stamp out magic, and simultaneous attempts to brand Sextus Pompey and his followers as devotees of necromancy (significantly, Canidia is shown practising this in the contemporaneous Satires I).” For the "push to stamp out magic," see also note 257.

276 Acc. to Cassius Dio (49.16.2) (Freyburger \& Roddaz, 1994, 126): “One Gaius Maecenas, a knight, took care of the remaining matters in Rome and in the rest of Italy, both then and for a long time

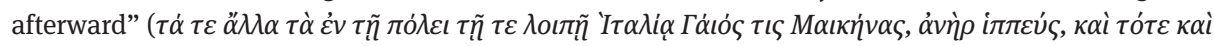


of the Esquiline, and the final lines can be read as complimenting Maecenas on his efforts: the witches are a good riddance. The strategic issues referred to in both poems are the threat from Parthia and Egypt, and the alliance between Cleopatra and Marc Antony. Horace alludes in both to the latter's submission to Cleopatra. In S.1.7, he implicitly reproaches Antony with his mismanagement of his military and political responsibilities, and in $S .1 .8$ with his compliance with Cleopatra's aspirations to create her own imperium in the East. Horace transmits in both the message to Maecenas that he supports the political agenda of Octavian, that is that Marc Antony ought to be removed, and that he takes Octavian's side in the struggle for power against Antony.

\subsubsection{Sermones 1.9 and 1.10: Maecenas' Circle: No Place for Nouveau Riche. Horace's Literary Programme for Several Genres; the Literary Schools Revisited}

Having attended to weighty matters as the state of the imperium and the future of the conflict between Octavian and Antony in the previous two poems, Horace returns in S.1.9 to the central issue of the state of his relationships with Maecenas. ${ }^{277} \mathrm{He}$ pursues in the present poem the subjects that he described in S.1.5 and S.1.6., that is his appreciation of being admitted to the circle of Maecenas and his contentment with his achievements so far. I noted already briefly in section 2.2.3 at the conclusion of my analysis of $S .1 .5$ that the fifth and the present sermo also have much in common in structure. Both poems describe a journey, albeit the one in S.1.5 from Rome to Brundisium is much longer than the stroll in Rome in S.1.9. Gowers $(2012,305)$ notes already that both poems were written with "humour with a light touch." In addition, I note that the opening lines of the two poems are also somewhat similar: S.1.5.1 reads EGRESSUM magna me accepit Aricia Roma (After I left mighty Rome, Aricia took me in) and S.1.9.1 is IBAM forte via Sacra, sicut meus est mos (I happened to be strolling along the Via Sacra, as I am used to). Further, both poems are also concerned with meeting people, both strangers and friends. For example, in S.1.5.34-36 the meeting with pompous local dignitary Aufidius Luscus is recorded, and in S.1.5.51-70 that with vulgar Sarmentus, whom he sees as a parasite. Horace writes about those strangers in a condescending manner, not wanting to be associated with them in any way. I hope to demonstrate in the coming analysis of S.1.9 that this is very similar to Horace's response to the impertinent fellow who dominates the scene in this poem. With respect to friends, he expressed in S.1.5.39-44 the joy of his association with his colleagues, Virgil, Varius and Plotius. We will see in S.1.9.60-74 first his delight

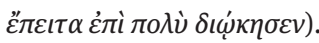

277 For S.1.9 in general, see Anderson (1982, 84-102); Buchheit (1968); Cloud (1989, 65-67); Connors (2005, 133-135); Courtney (1994); (Gowers (2012, 280-304); Henderson (1993); Mazurek (1997); McGann (1973); Musurillo (1964); Oliensis (1998, 37-39); Rooy van (1972); (Rudd, 2007, 74-85); Welch (2001). 
and relief when his dear friend Fuscus Aristius arrives (Fuscus Aristius occurrit, mihi carus), but afterwards his disappointment when Fuscus fails to come to his rescue.

The similarity in theme between S.1.6 and S.1.9 appears for example in S.1.6.122123 with the enjoyment he finds in his intellectual pursuits of reading and writing. The style of the narration in the opening line of S.1.9 also recalls the words at the end of the sixth sermo: in S.1.6.122 he stays in bed till ten o'clock (ad quartam iaceo) and then takes a stroll (post hanc vagor), and in S.1.6.128-129 he states that the life he enjoys is only for those who are released from burdensome and pitiable ambition (haec est/ vita solutorum misera ambitione gravique).

When I discussed S.1.5, I argued that I consider the events described in the poem as examples of Horace's poetic fiction. In my view, there are several arguments for also interpreting the stroll and the confrontation with the impertinent fellow of S.1.9 as such. Firstly, the analogy of structure and theme between the fifth and the ninth sermo suggests that Horace worked in the same pattern. Secondly, as I briefly indicated in the introduction of $S .1 .5$, the objective of those two poems was primarily to present to Maecenas his views on their relationship. I explained in the analysis of the fifth sermo that Horace gave those views by using the form of the first-person persona (Horace) who presents himself as engaged in fictitious events. This way Horace could arrange an informal setting for the interchange of views and Maecenas could choose whether to react or only to listen.

S.1.9 starts with a description of one of the pleasures of his life in the city, that links closely with the words of the closing lines of S.1.6: he is released from burdensome and pitiable ambition. The first words of S.1.9 express that he has the opportunity to be more pleasantly occupied. S.1.9.1-2 reads:

IBAM forte via Sacra, sicut meus est mos, nescio quid meditans nugarum, totus in illis.

(I happened to be strolling along the Via Sacra, as I am used to, pondering some trifling matters, totally absorbed in thought)

Then in S.1.9.3-5, Horace is roughly roused by a man whom he only knows by name running up to him and grasping his hand (accurrit quidam notus mihi nomine tantum,/ arreptaque manu), and who says to him "how are things, dear chap?” ('quid agis, dulcissime rerum?'). Horace replies curtly "fine at the moment, and all the best to you" ('suaviter, ut nunc est,' inquam, 'et cupio omnia quae vis.'). However, Horace was not well rid of the man that easily. S.1.9.6-8 reads:

cum adsectaretur, 'num quid vis?' occupo. at ille

'noris nos' inquit; 'docti sumus.' hic ego 'pluris

hoc' inquam 'mihi eris.'

(as he kept following me, I got in first "nothing else you want, is there?” And he said "you should become acquainted with me; I am a poet." And to this I said "so much the better") 
In lines 8-13 Horace desperately tries to shake off the pest (misere discedere quaerens), starts to quicken his leisurely pace (ire modo ocius), stops now and then (interdum consistere), and whispers something or other in his slave-boy's ear (in aurem/ dicere nescio quid puero) without telling us what he whispers. The sweat stands in his shoes (cum sudor ad imos/ manaret talos; literally: while the sweat trickled down to the lower parts of my ankles). He kept grumbling to himself (aiebam tacitus) "Bolanus, happy in your hot temper" ('o te, Bolane, cerebri/ felicem!'). ${ }^{278}$ Bolanus is unknown, but Gowers $(2012,286)$ suggests that he perhaps was "a satirist with a more open style of operation.” Horace tells us in S.1.9.12-13 that the pest goes on burbling about all kinds of things, but Horace mentions in particular his praise for the quarters of the city and the whole of Rome (cum quidlibet ille/ garriret, vicos, urbem laudaret), presumably referring to Octavian's refurbishing programme. Horace decides that the best way to get rid of the man is to give him the cold shoulder. In lines 13-21 the pest shows himself in his true colours: stubbornly persistent he clings to Horace, who initially refuses to reply (ut illi/ nil respondebam). The man, however, reads Horace's mind saying in S.1.9.14-16:

\footnotetext{
'misere cupis' inquit 'abire;

iamdudum video: sed nil agis; usque tenebo; persequar hinc quo nunc iter est tibi.'

(he said "you desperately want to go away; I saw that a long time ago. But it's no use, I'll keep with you all the way; I'll stay with you from here to the end of your journey.")
}

Horace breaks his silence, perhaps with a white lie or telling the pest the real purpose of his stroll: a social call. In lines 16-18 he says "there is no need for you to make a detour" ('nil opus est te/ circumagi'). He is planning to visit a sick man, whom the pest does not know, a long way off across the Tiber ('quendam volo visere non tibi notum:/ trans Tiberim longe cubat is'). The reference 'prope Caesaris hortos' ("near Caesar's gardens") suggests that Horace's (probably fictitious) patient lived in or near to the quarter of modern Trastevere. The gardens left by Julius Caesar to the people of Rome were on the hill called Janiculum (modern Gianicolo) on the right bank of the Tiber, near Trastevere. However, Horace's poor excuse does not put the impertinent fellow off, making the poet at his wits' end. S.1.9.19-21 reads:

'nil habeo quod agam et non sum piger: usque sequar te.'

demitto auriculas, ut iniquae mentis asellus,

cum gravius dorso subiit onus.

("I have nothing to do and I am not averse to walking; I'll stay with you all the way." My ears drooped, like an unwilling donkey's, when it has got a load too heavy for its back)

278 I follow Gowers' $(2012,286)$ rendering of cerebri felicem. 
Instead of dropping his plan, the fellow even goes so far as to display his poetic and artistic qualities. S.1.9.21-25 reads:

\author{
incipit ille: \\ 'si bene me novi non Viscum pluris amicum, \\ non Varium facies: nam quis me scribere pluris \\ aut citius possit versus? quis membra movere \\ mollius? invideat quod et Hermogenes ego canto.' \\ (he began: "If I know myself well, you will not regard Viscus or Varius more as a friend than \\ me: for who can write more verses than I, or write faster? Who can dance more gently? And my \\ singing makes even Hermogenes envious")
}

The pest could not have done worse. He mentions the wrong people or qualities. L. Varius Rufus is indeed a good friend of Horace, whom he mentioned already in S.1.5.40 as one of the friends on the journey to Brundisium and in S.1.6.55 as the friend who together with Virgil introduced him to Maecenas. He will mention Varius seven more times in his work, often in the same breath with Virgil. Although one of the Visci brothers or both also belonged to the circle of Maecenas, nothing certain is known of them, but there are no indications that Horace ranks him or them as a special friend. ${ }^{279}$ The fellow makes a serious mistake with respect to Horace by placing himself above Virgil for Horace's affection. The fellow's next assertion that he can write verses fast and many is also a fundamental error in Horace's eyes. He obviously did not read what Horace wrote about Lucilius in S.1.4.9-10: Lucilius was faulty, in an hour he would often dictate two hundred lines standing on his head [lit. standing on one foot = with great ease], as though it were a big deal (nam fuit hoc vitiosus: in hora saepe ducentos,/ ut magnum, versus dictabat stans pede in uno). And finally, Horace should not be reminded of the despicable Hermogenes who was described by the poet in S.1.3 as a hypocrite very able to change sides, eventually probably to Sextus Pompey.

Maecenas will immediately recognise that the impertinent fellow is not "one of them." The fellow seems to demonstrate that he does not know Horace and his friends at all and that he projects an image of Horace and his associates that does not correspond to reality. However, if one reads the poem from the perspective of his credentials for Maecenas, it is likely that Horace wrote the passage of S.1.9.21-25 with intent to prepare the ground for the (fictitious) dialogue between Horace and the fellow in S.1.9.43-60. In that case, the design of the poem is that Horace lets the pest, an outsider, describe Maecenas' circle as a group that is nothing more than an ordinary collection of people, who spend their time dancing and singing and are

279 L.Varius Rufus is mentioned in S.1.10.44, 81; S.2.8.21, 63, Ep.2.1.247, Ars.55, Carm.1.6.1, of which four times together with Virgil. The Viscus brothers are mentioned in S.1.10.83 and Viscus Thurinus in S.2.8.20. White (see note 45) mentions the Visci as belonging to the circle of Maecenas. 
interested in nothing else. This gives first-person persona Horace the opportunity to communicate to Maecenas in lines 43-60 that he feels that he belongs to a circle of high intellectual and artistic repute. He says in lines 48-49 that the members of the group do not live as the pest thinks they do, and that their standards are higher than those of similar circles or of those in a patron/client arrangement. All this points again to a poem, in which the scene of the stroll, the pest accosting, and the visit to the court are poetic fiction.

Then, Horace seizes his chance to regain the initiative (interpellandi locus hic erat). In lines 26-27 he poses the question "do you have a mother or kinsmen, who are concerned for your well-being?” ('est tibi mater,/ cognati, quis te salvo est opus?'). Horace rebukes the fellow in the form of an apparently innocent question, that can be understood as a way of saying "clear out, go and annoy your relatives, they may be impressed by your superior qualities." Horace hopes that this may send the bore packing, but the latter either ignores the question or is too dense to understand the point. He gives a straight answer in lines 27-28 "not one. I buried them all” ('haud mihi quisquam;/ omnis composui.'). Horace tries again: "Lucky they are; now I'm next" ('felices! nunc ego resto').

In lines 29-34, Horace shows his frustration that the bore clings to him and instead of enjoying his future days with Maecenas and his companions, he sees for his mind's eye a future with this impertinent fellow with perhaps many more of those in his trail: a fate worse than death. This reminds him of a prophecy from his boyhood. S.1.9.29-34 reads:

\footnotetext{
'confice; namque instat fatum mihi triste, Sabella quod puero cecinit divina mota anus urna: hunc neque dira venena nec hosticus auferet ensis, nec laterum dolor aut tussis, nec tarda podagra; garrulus hunc quando consumet cumque: loquaces, si sapiat, vitet, simul atque adoleverit aetas.'

("finish me off; for the grim fate hangs over me, which an old Sabellian woman, shaking her prophetic urn, prophesied to me when I was a boy: 'no dreadful poisons or hostile sword, no pleurisy or cough or slow-footed gout shall kill him. But a garrulous man will devour him at some time or other. If he be wise, let him avoid the loquacious as soon as he matures in age'.”)
}

The prophecy in lines 31-34 was given to Horace by an old Sabellian woman when he was a boy. Horace is rightly terrified as he thinks that he has now met "the garrulous man [who] will devour him," namely the pushy fellow who does not stop talking. We saw in the discussion about Horace's origins in section 1.3.1 that Williams (1995, 301304) presents the interesting proposition that Horace was not born in Venusia itself, but somewhere in the region. I quoted Williams $(1995,303)$ that "the poet regards himself as belonging to one of the pre-Roman Sabellian tribes.” Williams $(1995,301)$ specifically refers to S.1.9.29, when he says: 
Horace specifically represents himself as a Sabellian. Hence the terrifying prophecy given to him as a child that he suddenly remembers when he cannot escape from the pushy social climber (neither poison nor sword nor illness will be the end of him, only a compulsive talker); this prophecy was given to him by an old Sabellian woman.

Williams supports his proposition by also referring to Horace meeting the jurist C. Trebatius Testa in S.2.1. His argument is that the latter was perhaps the grandson of a Trebatius whom Appian in Bellum civile.1.228-229 mentions. ${ }^{280}$ This latter Trebatius was the leader of rebel forces in Apulia during the Social War in 89 B.C., at the time that Venusia came again under Roman control. Williams $(1995,303)$ suggests that "the families of the poet and the jurist had been friends of long standing, and shared in common the same puzzle over tribal identity.” In my view, Williams' proposition that Horace was of Sabellian origin is very attractive; that is not to say that I consider either S.1.9, or the prophecy of the Sabellian woman as autobiographical.

What does the prophecy mean? Horace says that if he were to be forced to spend his time with insensitive simple-minded men like the compulsive talker in what resembles an intellectual and artistic wasteland, he would rather be dead. But, the arrival of the two at Vesta's temple in line 35 (ventum erat ad Vestae) may be the beginning of the saving of Horace. S.1.9.35-40 presents the next wrangle between the two. It was about ten o'clock in the morning (quarta iam parte diei/ praeterita). Horace tells us this presumably to let us know that he spent already some good two hours with the fellow. We learn from S.1.9.36-37 that as it happened it was also the hour the fellow had agreed to meet at the temple of Vesta the plaintiff in a case against him and next to appear (before the praetor) in court, bail having been granted, and if he failed to appear, he could lose the case (et casu tunc respondere vadato/debebat; quod ni fecisset, perdere litem). ${ }^{281}$

The pest's next attempt to engage Horace in his plans is described in S.1.9.3840. He asks that Horace does him a favour as a friend by helping him ('si me amas' inquit 'paulum hic ades.'), by being present at the court and by giving legal advice. The pest wants the best of both worlds: Horace who cannot escape from him and Horace who supports him in court. Horace gives primarily an answer on the second option,

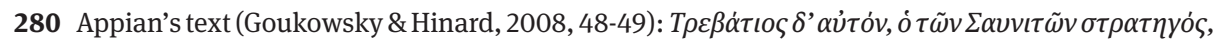

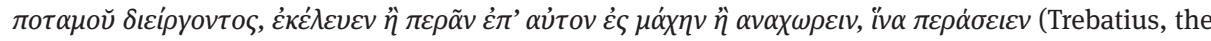
general of the Samnites, who was separated by the river [Aufidus], urged him either to cross the river and fight or to withdraw so that he himself could cross). For the question whether Horace grew up in Venusia proper or in the wider region, see also the discussion at S.1.5.89-91.

281 According to Cloud $(1989,66)$ Horace is not right when he says in line 37 that "if the pest fails to answer bail, he will lose his case (litem) whereas, strictly speaking, he will lose his bail-money rather than his case, for there will not be a case to lose." The pest and the plaintiff were still at the first stage when the praetor "would clarify the legal form of the dispute between them and then remand the case to be decided by an adjudicator (iudex)" (Cloud, 1989, 65-66). For the juridical background, see also Gowers (2012, 292). 
presumably to show up the fellow's opportunism. He uses strong language refusing when he says "I am damned, if I am capable of standing up in court, or have knowledge of civil law; and I am in a hurry, you know where" ('inteream si/ aut valeo stare aut novi civilia iura; / et propero quo scis'). This answer gets the fellow into trouble. He is so keen to stay in touch with Horace that he seems prepared to lose his bail and indeed the case by not showing up. The pest thinks aloud in lines 40-41: "I ask myself what to do, whether to leave my case or you ('dubius sum quid faciam' inquit,/ 'tene relinquam an rem'). Horace answers as expected "me please" ('me sodes'), and the pest says also as expected "no, I won't [leave you]" ('non faciam'). In the following lines, the two move on again; the pest leads the way (et praecedere coepit), and Horace follows him meekly admitting his defeat as it is difficult to fight with one's victor (ego, ut contendere durum est/ cum victore, sequor).

I mentioned above that I regard the passage that follows, S.1.9.43-60, the core of the poem. Horace voices in those lines what he sees as the power of Maecenas and his companions. His statement begins with a question posed by the pest in lines 43-48:

'Maecenas quomodo tecum?'

hinc repetit: 'paucorum hominum et mentis bene sanae;

nemo dexterius fortuna est usus. haberes

magnum adiutorem, posset qui ferre secundas,

hunc hominem velles si tradere: dispeream ni

summosses omnis.'

(He [the pest] resumes from this point: "how do you get on with Maecenas? One who has few friends, one with sound judgement. Nobody used his good fortune more skillfully. You could have a good assistant, who could take the second place, if you would introduce yours truly [the pest]: may I perish, if you would not send all the others away.”)

According to Gowers (2012, 294) "for this section [lines 44-60), the two voices [of Horace and the pest] run together confusingly," and she states that line 44 “is probably H.[orace]'s voice." The poet, who intends to write positively about Maecenas' capacity to bring people together, refers back in lines 44-45 to what he wrote in S.1.6 about Maecenas' powers of discernment in choosing his friends, which he also praised in S.1.6.63-64 and before in S.1.6.5-8 and S.1.6.51-52. However, I do not conclude that it therefore follows that those words were spoken by Horace and not by the pushy fellow. Although either of them could be the "speaker," I conclude that on grounds of the context of lines 45-48 (the pest offering himself to be Horace's assistant in Maecenas' group) the pest is the "speaker" in those lines. ${ }^{282}$ But, there

282 My view is also contrary to Oliensis $(1989,38)$, who like Gowers sees Horace as the speaker of line 44: "Horace replies by answering what he takes to be the 'real' question ('how do you think I would fare with Maecenas?'): 'He's a man of limited acquaintance and of very sound mind' (paucorum hominum et mentis bene sanae, 44)." I place the quotation-marks acc. to the OCT, i.e. at different places than Gowers $(2012,54)$. 
is yet another important aspect to S.1.9.43-48, that is that those lines are meant by the poet as a preparatory step for his "first-person persona" fictitious reply in lines 48-52 and indeed in the ensuing fictitious dialogue in lines 52-60. Horace's purpose of the dialogue is the same as that in for example S.1.6, namely to offer the evidence of his worthiness of Maecenas' friendship. In S.1.9, the poet chose the medium of the fictitious meeting with the pushy fellow for communicating this message to Maecenas. His description of the meeting is an opportunity to depict the special character of the circle. Oliensis gives a similar reading of S.1.9.48-53 as I do; she $(1998,39)$ states "But what matters here is less the truth-value than the pragmatic value of Horace's idealizing description of Maecenas' circle. The encounter gives Horace a chance to act the part of a faithful friend - a man who knows both to keep his mouth shut and when to open it." S.1.9.45, 'nemo dexterius fortuna est usus' ("nobody used his good fortune more skilfully") can be read in two ways, either the fellow's commentary on Maecenas' success in choosing his associates or on Horace's success in being chosen. According to Oliensis $(1998,38)$, line 45 refers to the latter's success: if it is so difficult to approach Maecenas [paucorum hominum], you Horace did well for yourself being accepted. Contrary to Oliensis, I read the words "nobody used his good fortune more skillfully" as in fact a continuation of the words in line 44: "one who has few friends, one with sound judgement.” In summary, both lines (44 and 45) refer to Maecenas and the poet gives those lines to the pest who says: Maecenas has few friends, but he is a man of good judgment and used this most skillfully to choose those friends.

The pest continued harassing Horace when he offered in his good offices to the poet by suggesting that he could well be a suitable (S.1.9.45-46) (adiutor) assistant of Horace, enabling him to rise even further in Maecenas' estimation. Once he holds the post, the schemer will make sure that Horace sends all the others (omnis), his good friends, packing. In the words of Brown $(2007,180)$ "displacing Horace's 'rivals' in Maecenas' esteem.”

Then, Horace "speaks" the important lines 48-52 in reply to this suggestion of the brute. S.1.9.48-52 reads:

'non isto vivimus illic

quo tu rere modo; domus hac nec purior ulla est

nec magis his aliena malis; nil mi officit' inquam

'ditior hic aut est quia doctior; est locus uni

cuique suus.'

(I said “we don't live there the way you think; no house is more faultless or more unfamiliar with such evil; it doesn't hurt me that someone is richer or more learned than I am; each has his own place.”283

283 There is a significant difference in punctuation between OCT and other editions, e.g. Brown (2007, 78; 180), Gowers (2012, 54; 295), Rushton Fairclough (Loeb), (1999, 108), which give for lines 5051: nil mi officit, inquam,/ ditior hic aut est quia doctior (it doesn't hurt me, I can tell you, that someone 
In this poem with his credentials, the first-person persona Horace, who speaks here as the poet Horace would, gives in these lines a warm compliment to Maecenas for the mutual relations within the circle of associates. White $(1993,38)$ observes that "it makes more sense to suspect that Horace's picture [of the relations among Maecenas' protégés] in Satire 1.9 is greatly idealized.” Horace's picture may be idealized, but it is very appropriate to the purpose of the sermo, that is his explanation to Maecenas that he feels at home in the latter's company. Gowers notes that S.1.9.51 refers back to S.1.1.40 where Horace says nil obstet tibi dum ne sit te ditior alter (nothing can stop you, so long as you can prevent someone else to be richer than you), speaking of the greedy men who do not stop amassing riches. Horace shows in S.1.1-1.4 repeatedly his concern about these themes, which he sees in the unlimited ambition and pursuit of luxury of several groups in Roman society. S.1.9.51 is in the words of Gowers (2012, 295) "a calculated disavowal of invidia (envy) and ambitio."

The ensuing exchange between Horace and the pest in S.1.9.52-60 shows the latter's colours. The first reaction of the fellow is one of disbelief. In line 52 he says to Horace: "you are telling a tall story, hardly credible.” ('magnum narras, vix credibile.'). Horace answers: "all the same, that's how it is." ('atqui/ sic habet.'). Then, the fellow says in lines 53-54 "you make me all the keener to get close to him." ('accendis, quare cupiam magis illi/ proximus esse.'). ${ }^{284}$ In the next lines, Horace encourages the pest to try his luck to be admitted, presumably because he is fed up with the man and his offensive manners. At the same time, he does not believe that Maecenas would be impressed by the fellow and would not accept him anyway. Horace urges him in S.1.9.54-56 to attack the "fortress-Maecenas" suggesting that he will win if he wants to:

'velis tantummodo, quae tua virtus,

expugnabis; et est qui vinci possit, eoque

difficilis aditus primos habet.'

("you have only to want it, such is your spirit, you will take the fortress; and he is a man who can be won, and that is why he makes the first approaches difficult”)

Horace lets it appear in that Maecenas is difficult to approach, because he wants to protect himself knowing that he can be won. The fellow walks into the trap in lines 56-60:

'haud mihi deero:

muneribus servos corrumpam; non, hodie si exclusus fuero, desistam; tempora quaeram; occurram in triviis; deducam. nil sine magno vita labore dedit mortalibus.'

is richer or more learned than I). I follow the OCT - edition. 284 For lines 53-54, I have used Gowers' $(2012,296)$ rendering. 
("I won’t let myself down. I will bribe his slaves with presents. I will not give up, if I am refused to-day. I shall seek out the right moment. I will run into him accidentally in the streets. I will escort him. Life did not give anything to mortals without great effort.")

In the passage of lines 54-60, Horace feels obviously that only by expressing himself strongly the fellow can be brought to reason. The pest is not slow to react announcing a very aggressive strategy to break into Maecenas' circle. Gowers $(2012,296)$ points out that the words that both use is "a new round of military metaphors," suggesting that the battle between the two reaches its peak. In my opinion, the words used by the fellow do not have primarily a distinct military ring suggesting that he was a military man, but they typify him even more as an aggressive businessman with unscrupulous methods: bribery, dubious tenacity, at the cost of his victims seizing his opportunities. There is yet another side to the kind of reaction put into the fellow's words by the poet. The words of S.1.9.54-60 may also be meant as to indicate to Maecenas the perception that many in Rome have of him and his companions: an exclusive clique with too many connections with the people in power.

This is also one of the themes of the next section, S.1.9.60-74. At the beginning of this section it seems that Horace is rescued by his good friend Aristius Fuscus. In lines 60-61 we read: while he goes on in this way, look, Aristius Fuscus bumped into us, a dear friend of mine (haec dum agit, ecce/ Fuscus Aristius occurrit, mihi carus). Porphyrio in his commentary on S.1.9.60 identifies Aristius Fuscus as a very distinguished grammarian at the time (praestantissimus grammaticus illo tempore), and in that on Ep.1.10 as a writer of comedies (scriptorem comoediarum). Aristius Fuscus returns in S.1.10.83 - together with poets like Virgil, Plotius Tucca, C. Asinius Pollio and others approving of Horace's verses (probet haec) and praising (laudet) these. Aristius Fuscus was most likely not a member of Maecenas' circle, but a friend of Horace from a different background. ${ }^{285}$ Aristius, the dear friend of Horace appears to know the mysterious fellow quite well (et illum/ qui pulchre nosset) (lines 61-62). Horace and the fellow stop to have a chat with Aristius (consistimus), and the poet clearly hopes that his friend will help him out. A diffident conversation starts in lines 62-63: 'unde venis?' et/ 'quo tendis?' rogat et respondet (he asked me "from where do you come?" and "where do you go?," and he told me his errand). I take it that Aristius asked the questions (rogat). The story does not give us either Aristius' answer (respondet) or that of Horace: thus it is not clear to which errand Horace may have referred: his stroll along the Via Sacra, his feigned visit to a sick man across the Tiber of lines 16-18, or his expedition to the court as a companion and advisor of the fellow of lines 38-40. The expedition to the court is the most likely in the light of

285 Nisbet \& Hubbard (2001, 261-262); Rudd (2007, 75-76). Aristius Fuscus is the dedicatee of Carm.1.22 ("Integer vitae"), and in Ep.1.10 we meet him again. White (1993, 35-63) does not mention Aristius Fuscus as a member of Maecenas’ circle (see also note 45). 
Aristius' excuse in lines 69-70 when the latter says that he cannot be involved as it is the thirtieth Sabbath. I will explain this in more detail below.

Horace, however, is desperate to tell him his predicament with the fellow as S.1.9.63-68 shows:

\author{
vellere coepi, \\ et pressare manu lentissima bracchia, nutans, \\ distorquens oculos, ut me eriperet. male salsus \\ ridens dissimulare: meum iecur urere bilis. \\ 'certe nescio quid secreto velle loqui te \\ aiebas mecum.' \\ (I began to tug [his cloak], and to squeeze his unresponsive arms, nodding and rolling my eyes for \\ him to deliver me. Sick joker that he was, he chose to laugh and fake incomprehension: I seethed \\ with rage. "Surely you said that there was something you wanted to tell me in private") ${ }^{286}$
}

In spite of Horace's pinching and winking and his efforts to have a quick word with Aristius, he does not succeed in getting the latter interested. The words in lines 67-68 about something that Aristius wanted to tell Horace in a private talk are a pretence to set the pushy fellow apart, but Aristius does not react in the way Horace had hoped. Although Aristius joins in Horace's game, he plays for time: in lines 68-70 he answers "I remember it well, but I will tell you on a more suitable moment" ('memini bene, sed meliore/ tempore dicam'). He explains his refusal with the excuse that "to-day is the thirtieth Sabbath. Do you wish to fart at [= insult] the circumcised Jews?" ('hodie tricesima sabbata: vin tu/ curtis Iudaeis oppedere?'). The excuse is generally not satisfactorily explained. McGann $(1973,89)$ sees the excuse as "maliciously offering only a piece of pseudo-erudition," but does not explain this view. ${ }^{287}$ In my opinion, the most likely general conclusion is the one formulated by Gowers $(2012,300)$ that the excuse refers to a "conscientious objection to civic duties (specifically serving as witness/prosecutor) because today is the thirtieth Jewish Sabbath)." Gowers' conclusion assumes that Horace had the opportunity to inform Aristius about the nature of his involuntary errand, that is that the fellow and he were on their way to the court. The meaning of the "thirtieth Sabbath" cannot be explained satisfactorily, but it may refer to an important Jewish feast-day when one is not permitted to do any work, particularly such as serving as a witness or a prosecutor. That is why Aristius says that he does not want to insult the Jews, but his grounds for his respect for the Jewish rules are not made clear. The view that Aristius pretends that respect for religious rules motivates him to refuse assisting Horace is endorsed in S.1.9.70-72. For, however it may be, Horace refers to religious principles when he replies "I have

286 The OCT has in line 64 prensare (to clutch at). I follow Gowers $(2012,299)$ and others who argue for pressare (to squeeze) as the preferred manuscript reading. I have also used Gowers' rendering of lines 65-66, male salsus/ ridens dissimulare.

287 For the meaning of Aristius' excuse, see also Gowers (2012, 300). 
no religious scruples" ('nulla mihi' inquam/ 'religio est'), and Aristius answered "but I have. I am somewhat weaker in character, one of many. Excuse me, we will talk another time" ('at mi: sum paulo infirmior, unus/ multorum: ignosces: alias loquar.'). That is the end of the meeting with Aristius without a chance for Horace to explain his problem with the fellow. The disillusioned Horace gives in S.1.9.72-74 his calm commentary on this fictitious event: to think that such an evil day had dawned on me! The rotter disappears and leaves me in a fix (huncine solem/ tam nigrum surrexe mihi! fugit improbus ac me/ sub cultro linquit). ${ }^{288}$ I do not concur with Rudd $(2007,76)$ that "Fuscus turns traitor. Horace's hopes are again dashed, and the scene closes leaving him a helpless and deserted victim." But, Horace does not bring Aristius Fuscus on the stage to show the failure of a friendship. Aristius remains a friend in S.1.10, in Carm.1.22 and Ep.1.10. It seems to me that the "excuse" of his religious scruples which Aristius makes to the first-person persona Horace is a pretext, as Aristius had decided not to become involved in a potential conflict about the admission of somebody, whoever he may be, to Maecenas' circle.

At this point in the mini drama, we have three actors who in different ways are concerned with membership of the circle of Maecenas. The first one is Horace, whose position we know: appreciating that he was admitted to the circle and content with his achievements so far. The second one is the anonymous fellow who is keen to advance his career by being admitted, but whom Horace does not see as a suitable candidate. He is not and will not be one of them, although Horace does not explicitly state this. We have to glean his opinion from the allusions in the present poem. The picture we get is that of a man, who is highly ambitious but very impertinent and brash. He introduces himself in line 7 as a scholar and in lines 22-25 as an accomplished poet, dancer and singer. As far as Horace is concerned, however, he boasts of the wrong qualities like his fast writing, and admires the wrong people, like Hermogenes. He is also aggressive and vulgar in pursuing his goals. Horace pursues in S.1.9 subjects that he described in S.1.1, S.1.5 and S.1.6. For example, Gowers notes that S.1.9.51 refers back to S.1.1.40. Line 51 of the present poem is in the words of Gowers $(2012,295)$ "a calculated disavowal of invidia (envy) and ambitio." In addition, the opening of S.1.9 links closely with the final lines of S.1.6: Horace is released from burdensome and pitiable ambition. Further, I noted that S.1.9 also contains significant echoes of S.1.5. The present and the fifth sermo have not only much in common in structure, but the two also share partly a common theme. The meeting with the pushy fellow of S.1.9 reminds us of the meetings with a pompous local dignitary in S.1.5.34-36 and that with a vulgar parasite in S.1.5.51-70, with both of whom Horace does not want to be associated. Horace gives us some indications with respect to the fictitious social position of the pushy fellow of S.1.9. He tells us in S.1.9.12-13 that the fellow praises particularly the quarters of the city

288 For the rendering of huncine solem/ tam nigrum surrexe mihi! in lines 72-73, I followed Gowers (2012, 301). 
and the whole of Rome, presumably referring to Octavian's refurbishing programme. If we look at the key characteristics of the fellow, namely his ambition, envy, and common behaviour, I suggest that he is a nouveau riche businessman known for his very shady methods in his ventures. Although he showed himself off as a scholar, poet, and singer of sorts, I conjecture that it is more likely that he, in view of his appreciation of Octavian's building programme, symbolizes one of the many who got rich in real estate. The extravagance in building was a particular touchy political issue at the time of writing S.1.9. Horace himself wrote two poems about the issue, namely Carm.2.15 and Carm.2.18. ${ }^{289}$ The latter is most likely written in the years before 30 B.C., when he also wrote the books of Sermones. ${ }^{290}$ Nisbet and Hubbard $(2004,288)$ note that "the Roman orators were fond of denouncing extravagance, particularly in building." Contemporary evidence is found in Cicero's Pro Sestio (CIC.Sest.93). ${ }^{291}$ The third actor who is concerned with membership of the circle of Maecenas is Aristius Fuscus, although in a very different role. He is not a member of Maecenas' circle. I conjecture that the reason why Aristius refuses to help Horace in his predicament with the pushy fellow is that Aristius symbolizes the position of the man who takes exception to the exclusive character of the group and thus does not want to be involved. We saw already that the passage S.1.9.54-60, which precedes directly the one about the arrival of Aristius, can be read as a description of the perception by many in Rome of Maecenas and his companions as an exclusive clique with too many connections with the people in power. Those who rejected the circle of Maecenas may have felt that the poets therefore could only survive as their masters' voices. I argue in Weeda (2010) that Horace, like Virgil and Propertius, succeeded to maintain their independence and wrote not only panegyric and supportive poetry, but also critical

289 For the issue of luxurious building by the new rich, see my discussion of Carm.2.15 and Carm.2.18 at the end of my analysis of S.1.1 and S.1.2 (section 2.2.1), my discussion of S.1.1.61-62, and notes 79 and 102.

290 Acc. to Nisbet \& Hubbard (2004, 290-291) the date of Carm.2.18 cannot be proved. The authors, however, point out that on grounds of intertextual similarities with both VERG.G.2.461-471 and LUCR.2.20-31 it is likely that Horace wrote Carm.2.18 before Virgil G.2. They $(2004,291)$ conclude that "if Horace has priority, the poem must be assigned to the triumviral period soon after the acquisition of the Sabinum [Carm.2.18.12-14].” Horace received the use of the estate at some time before 31 B.C.; hence the poem was likely written around 31 B.C. See also Weeda $(2010,128)$ and the section about Horace and Maecenas (1.4) of this book.

291 Cicero's text in Pro Sestio.93 is: villam aedificare in oculis omnium tantam, tugurium ut iam videatur esse illa villa, quam ipse tribunus pl. pictam olim in contionibus explicabat (that he [Gabinius] is building for all to see such a mansion that the villa, of which he himself when he was tribune of the commons displayed in the past a picture before meetings, that that villa looked like a hut). For a general discussion of the rejection of luxury, see Nisbet \& Hubbard (2004, 288). For a discussion of "the evils of wealth" in HOR.Ep.1.10, in which the poet also addresses Aristius, see Williams (1968, 578-579; 596-599). Luxurious villas were already denounced by M. Porcius Cato (234-149 B.C.) in CATO. orat.174, 185. 
political commentary about Octavian's policies and actions. Further, in lines 61-62 we are told that Aristius illum/ qui pulchre nosset (knew the fellow quite well), and presumably also knew what the man wanted Horace to achieve with Maecenas. The reason that Aristius did not want to be involved was that he did not want to embarrass his friend Horace. A second option is that Aristius symbolizes the man who previously was refused membership. In that case, it is self-evident that he does not want to know, despite his friendship with Horace.

The last five lines of S.1.9 close this mini drama, when the persona Horace is suddenly delivered. By chance the plaintiff of the fellow arrives and he does his own arrest to take the fellow to the tribunal for the clarification of the case by the praetor. The plaintiff had the right to do so under Roman law. There is a bit of shouting to and fro, and the figurative Horace offers his ear to be touched, which means that he is prepared to be a witness to the arrest. The fellow is carried off and thank the god of poetry Apollo Horace is delivered and his death by the garrulous man of the prophecy in lines 29-34 has been averted. S.1.9.74-78 reads:

\begin{abstract}
casu venit obvius illi
adversarius et 'quo tu turpissime?' magna

inclamat voce, et 'licet antestari?' ego vero

oppono auriculam. rapit in ius: clamor utrimque:

undique concursus. sic me servavit Apollo.

(by chance his opponent comes face to face with him and shouts loudly "where to do you go, you swine?, and [to me] "can I name you a witness to the arrest? I proffer my ear. He drags [the fellow] into court; shouting on both sides and tumult everywhere. Thus Apollo saved me) ${ }^{292}$
\end{abstract}

The last words in line 78 sic me servavit Apollo (Thus Apollo saved me) gave rise to much discussion. Miller (2009, 39-44) examines different opinions. ${ }^{293} \mathrm{He}(2009,41)$ considers the option that "Apollo rescued Horace not just from a general nuisance [the fellow] but from an egregious poet who characterizes his work in terms diametrically opposed to Horace's Callimachean ideals." This option refers to the fellow who boasts in lines 23-24 (see my discussion above) of his great quantity of verses and of "his speed at churning them out." Another option is that the words are an allusion to Brutus who at a drinking party had quoted a Homeric phrase referring to Apollo from either Iliad 16.849 or Iliad 20.443, probably in the presence of Horace. Miller $(2009,43)$ states also “that at Philippi 'Apollo' was said to be Brutus' watchword," an additional reference to Brutus. Miller $(2009,43)$ notes that "once again he [Horace] distances himself from his allegiance with Brutus and the republican cause a few years previously with an indirect reference." Although I am in sympathy with the view that Horace distances himself from his previous association with Brutus in several sermones in S.1, the

292 For licet antestari in line 76, I use the rendering of Gowers (2012, 302).

293 For Apollo's role in S.1.9.78, see also Gowers (2012, 303-304); Welch (2001, 173, note 25). 
indirect reference that Miller sees in the final word of S.1.9 (Apollo) is going too far. In my view, Horace intimates that he considers himself a mature poet, whose destiny is in the hands of the god of poetry as he will explain in the next sermo.

In summary: I argue in this book that the main objective of $S .1$ is to demonstrate to Maecenas that he will be a trustworthy member of the circle of Maecenas and that his past with Brutus is finished. Those are also the main themes of S.1.9, in which he depicts himself as a full member of Maecenas' circle expressing in S.1.9.48-52 his appreciation of the way the circle is organised by Maecenas. However, Horace also shows in this poem that he has friends who do not want to be involved with Maecenas, like Aristius Fuscus. It is likely that those friends perceive Maecenas and his companions as an exclusive clique with too many connections with people in high office. The poem shows Horace's pride at being recognised as somebody close to Maecenas, albeit by a pushy nouveau riche. He also feels perfectly capable of assessing whether somebody fits as an associate. The pushy nouveau riche, probably someone who made his money in real estate, clearly did not meet the criteria. But, without the help of Aristius he managed to get out of the predicament with the pest. And he is sure that Maecenas would go along with his judgement that a man like the pest would not fit. Further, Horace makes in S.1.9.78 the point that he has developed into an accomplished poet as he is saved from the nuisance of the fellow by Apollo, the god of poetry. Finally, with respect to the autobiographical nature of S.1.9, and indeed S.1.5, I refer to Williams' $(1968,569)$ statement that "in fact, no accurate answer is possible to the question whether Horace 'really experienced' the events which he describes [...]. What is important is that the answer to the question is irrelevant to the judging of the poem.” Next, Williams $(1968,570)$ states that in S.1.9 "the poet narrates the event from a position inside it, but this is mainly due to the very large scale of the narrative and to the poet's humorous treatment of it." I differ from Williams' view. My position on the autobiographical nature of both sermones - and indeed on others as well, as I explain in the analyses of the poems concerned - is that I assume that some events were really experienced by Horace, although presumably at different occasions, but that other events were invented. Horace gives us mixtures of both. S.1.9 as a whole is with respect to the historicity of the events similar to S.1.5, parts of S.1.6, S.1.7, and S.1.8. Horace creates narratives that serve his purpose of presenting his views on important issues for Maecenas to make up his mind about Horace's reliability in matters political. He uses regularly the instruments of the first-person persona and the functional reference to launch an opinion and open a discussion. In this way Horace prepares his platform as a commentator on political and social issues. In the final sermo, S.1.10, he will be again concerned with his style of delivering his message and literary orientation, like he did in S.1.3 and S.1.4.

We saw that the last word of S.1.9, "Apollo," can be understood as a prelude to S.1.10: Horace invokes the god of poetry because he considers himself a mature poet. The name of the god of poetry is a bridge leading to the opening of S.1.10, in which the poet 
will again present among other matters a statement about his literary orientation. ${ }^{294}$ However, there is a minor problem with this opening as the first eight lines are generally regarded as spurious; the lines are only found in one family of manuscripts and in other less reliable manuscripts. In addition according to Freudenburg (1993, 170), the style and the fact that none of the ancient commentators and authors seem aware of the lines also point to a problem of authenticity. ${ }^{295}$ Notwithstanding, I will briefly discuss those, as "even if they are not original, the lines constitute fascinating marginal comment on S.[1.]10" (Gowers, 2012, 309). The fragment is written by a supposed Horace and addresses the same question as the one in S.1.10 proper. This is according to Gowers $(2012,309)$

how to position himself vis-à-vis his great predecessor [Lucilius]. He [the pseudo Horace] elects to present the case against Lucilius by stressing the refinements of modern literary criticism [...], rather than taking a moral or social line (as he did in S.[1.]4) against those who show unthinking reverence for works of the past.

The fragment of S.1.10.1fr.-8fr. reads as follows: ${ }^{296}$

\begin{abstract}
[LVCILI, quam sis mendosus, teste Catone defensore tuo, pervincam, qui male factos emendare parat versus; hoc lenius ille, quo melior vir et est longe subtilior illo, qui multum puer et loris et funibus udis exoratus, ut esset opem qui ferre poetis antiquis posset contra fastidia nostra, grammaticorum equitum doctissimus. ut redeam illuc:]

(Lucilius, how mistaken you are, I will prove decisively on the evidence of Cato, your champion, who gets ready to correct your poorly executed verses. He is more gentle, because he is a better and much subtler man than the one who was much prevailed upon as a boy by lashes and moist ropes, so that there might be someone who could help the poets of old against our contempt, the most learned of equestrian grammarians. To continue with the case in point)
\end{abstract}

The author of the interpolated introduction makes the point that Lucilius' verses are poor and that Cato will provide the evidence. Horace made the same point earlier in S.1.4 about Lucilius' style and explicitly not about the content and his criticism of moral misconduct. Cato in S.1.10.1fr. is most probably P. Valerius Cato from Gaul who

294 For S.1.10, see Brown (2007, 182-194); Feeney (2009a); Freudenburg (1993, 100-104; 106; 165-184; 209-211; 2001, 66-71); Gowers (2012, 304-338); Rudd (2007, 92-124); Zetzel (2006). Freudenburg (1993, 209-211) discusses a different relationship of S.1.9 with S.1.10: "Satires 1.9 lends meaning to 1.10 [...] Satires 1.9 [modelled after Catullus 10] improves upon the contemporary imitators of Catullus in terms of their varietal technique, censured in 1.10.”

295 For the issue of the authenticity of the first eight lines, see also Gowers $(2012,309)$.

296 I indicate that the lines are part of the fragment by adding "fr." to the number of the line. 
according to Gowers $(2012,310)$ "allegedly studied Lucilius as pupillus of the firstgeneration antiquarian Vettius Philocomus (Suet.Gram.II.1) in the late 80s BC." Gallus called him a stern literary critic and Furius Bibaculus may have written about him "that he formed a new canon single-handed" (Nisbet, 1995, 391). ${ }^{297}$ Cato is described in the fragment as a civilized man who can be expected to correct Lucilius' style in a much subtler (longe subtilior) manner than someone who as a child was bullied into awe of Lucilius. If the author of the fragment knew Horace's experience of his schooling by Orbilius in Rome described in Ep.2.1.69-71 and in S.1.6.76-80, the boy (puer) of line 5fr. may well refer to young Orbilius and may suggest that the latter became a teacher, who was fond of flogging (plagosum Orbilium), as he himself experienced bullying as a boy. ${ }^{298}$ This identification puer is supported by the words of line $8 \mathrm{fr}$. grammaticorum equitum doctissimus (the most learned of equestrian grammarians): Orbilius was an eques and a well-known grammarian. ${ }^{299}$ If one accepts that the identifications of Cato (as Valerius Cato) and the grammaticorum equitum doctissimus (as Orbilius) are feasible, the unidentified author of the fragment conveys the following view: Lucilius' verses are faulty indeed and what Horace wrote in S.1.10 about those faults (of style) has the approval of the civilized commentator Cato, who is a far subtler adjudicator of the poets of old than for example Orbilius.

In S.1.10 proper Horace himself speaks again starting with a short résumé of S.1.4.1-13. Horace criticizes not only Lucilius' style of composing his verses in S.1.10.1-3, but he also testifies in S.1.10.3-4 to the fact that he had praised earlier Lucilius for his satiric power. $S \cdot 1 \cdot 10.1-4$ reads:

Nempe incomposito dixi pede currere versus

Lucili. quis tam Lucili fautor inepte est

ut non hoc fateatur? at idem, quod sale multo

urbem defricuit, charta laudatur eadem.

(certainly I said that Luculius' verses run on with disordered foot. Who is an admirer of Lucilius so foolishly as not to admit this? And yet, he is also praised at the same page because he rubbed down Rome with much wit)

297 For P. Valerius Cato, see Gowers (2012, 310); Nisbet (1995, 391-393); Suetonius writes about Valerius Cato in Suet.Gram.11 (see also Kaster, 1995, 151-161). The specific reference to Cato's study of Lucilius with Philocomus is in Suet.Gram.2: Laelius Archelaus Vettiusque Philocomus [pronuntiabant] Lucilii saturas familiaris sui, quas legisse se apud Archelaum Pompeius Lenaeus, apud Philocomum Valerius Cato praedicant (Laelius Archelaus and Vettius Philocomus spoke in public about the satires of their friend Lucilius, which Lenaeus Pompeius reported having read with Archelaus, and Valerius Cato with Philocomus); italics are mine.

298 For the identification of the second critic as Orbilius, see Nisbet (1995, 393): "This is surely Horace's old teacher, Orbilius of Beneventum.” For Horace's schooling by Orbilius, see also section 1.3.2, note 28, and my discussion of S.1.6.76-80 in section 2.2.3.

299 For Orbilius' status as eques and profession as grammarian, see SUET.Gram.9. For Orbilius, see also Folkerts (1972). Horace's remark in S.1.6 that he was taught as a boy in Rome together with sons of the elite also alludes to the equestrian status of Orbilius. 
In order to ease the comparison, I will first quote S.1.4.1-13 again.

\begin{abstract}
EVPOLIS atque Cratinus Aristophanesque poetae, 1
atque alii quorum comoedia prisca virorum est, si quis erat dignus describi quod malus ac fur, quod moechus foret aut sicarius aut alioqui famosus, multa cum libertate notabant. 5 hinc omnis pendet Lucilius, hosce secutus mutatis tantum pedibus numerisque; facetus, emunctae naris, durus componere versus: nam fuit hoc vitiosus: in hora saepe ducentos, ut magnum, versus dictabat stans pede in uno: 10 cum flueret lutulentus, erat quod tollere velles: garrulus atque piger scribendi ferre laborem, scribendi recte: nam ut multum, nil moror.

(Eupolis and Cratinus and Aristophanes, true poets and the other men of principle of old Comedy, if there was anyone deserving to be described as a ruffian and a thief, as an adulterer or murderer, or as otherwise notorious, they censured him with great freedom of speech. Lucilius wholly depends on them, and them he followed changing only metre and rhythm. He was witty, keen, but rugged in the composition of verses. In fact in this [ruggedness] he was faulty: in an hour he would often dictate two hundred lines standing on his head [lit. standing on one foot = with great ease], as though it were a big deal: when he flowed in his muddy stream, there was much you would like to remove: he was garrulous, and too lazy for the toil of writing - I mean of writing properly. For I am not interested in quantity)
\end{abstract}

Horace recalls in lines 1-3 of the tenth sermo the stylistic shortcomings of Lucilius mentioned in lines 6-13 of the fourth sermo. I will not repeat here the discussion of the latter, but only recall the conclusion. Lucilius carried the rugged versification to excess: the fault was due to his rapid work. Next, in S.1.10.3-4 Horace recalls S.1.4.1-5, a description of the subject matter that the poets of Old Comedy treated and he recorded with approval that they censured with great freedom of speech. In addition, the words quod sale multo/ urbem defricuit (because he rubbed down Rome with much wit) in S.1.10.3-4 are an echo of S.1.4.7-8, where he says that Lucilius was facetus,/ emunctae naris (witty and keen). He is positive about the manner in which Lucilius succeeded as a Roman successor to the best of the Old Comedy. In short, Horace was in S.1.4 critical of the style and not of the content of Lucilius' verses. ${ }^{300}$ Horace also refers back in S.1.10.16-17 to the opening lines of the fourth sermo; I will present my interpretation of this reference below. For the details of the discussion of the fourth sermo, I refer to that of S.1.4 in section 2.2.2.

300 Conform Freudenburg (1993, 101): "Far from apologizing for his earlier [in S.1.4] assessment of the Lucilianus character, the satirist [Horace] confirms his earlier views in very straightforward terms. He criticizes Lucilius for stylistic harshness, that is, his rough, unrelenting compositional style, not the harsh spirit of his invective." 
However, without delay Horace reduces his praise of Lucilius in S.1.10.3-4 in the following long passage, S.1.10.5-39. His line of argument goes as follows. If I were to condone a particular fault in Lucilius' poetry, I could just as well allow the same in any other poet's work. Thus, the key characteristic for his choice of any other poet in the present passage is that the latter shows a fault which he also identified with Lucilius. His first target among past and recent poets is Decimus Laberius (106-43 B.C.) in lines 5-6, followed by Licinius Calvus (82-47 B.C.) and Catullus (84-54 B.C.) in line 19, Pitholaus of Rhodes (first century B.C. - after 45 B.C.) in lines 20-24, and M. Furius Bibaculus of Cremona (born ab. 100 B.C., lived to a great age) in lines 36-39. I record at this stage two other features which he adds to his criterion for choosing any other poets. Firstly, all poets whom Horace censures in S.1.10.5-39 are known to have written lampoons against Julius Caesar, which suggests that Horace makes a political statement in favour of Julius Caesar and Octavian. Secondly, he will connect with his views on Lucilius' and any other poet's style his commentary on several other contemporary political issues. In each case, I will examine the issues concerned.

Horace says in lines 5-6: nec tamen hoc tribuens dederim quoque cetera: nam sic/ et Laberi mimos ut pulchra poemata mirer (however in granting him [Lucilius] this, I would not also give him the rest: for on that principle I should also admire the mimes of Laberius as beautiful poetry). Decimus Laberius was like Lucilius a Roman knight, who wrote according to Gowers $(2012,313)$ "mimes, ribald, semi-improvisational sketches with abrupt, haphazard endings.” Laberius wrote in an invective style, which Horace condemned in his and Lucilius' poetry. He also wrote lampoons aimed at amongst others Julius Caesar. Horace demonstrates to Maecenas by his rejection of Laberius' mimes that he not only dislikes the poetic qualities of Laberius, but also disapproves of the latter's attacks on Octavian's adoptive father and thus makes an implicit political statement against the anti-Caesarians.

Next, Horace states in lines 7-17 his view on the attributes of good poetry. The passage reads:

ergo non satis est risu diducere rictum

auditoris: et est quaedam tamen hic quoque virtus:

est brevitate opus, ut currat sententia, neu se

impediat verbis lassas onerantibus auris;

et sermone opus est modo tristi, saepe iocoso,

defendente vicem modo rhetoris atque poetae,

interdum urbani, parcentis viribus atque

extenuantis eas consulto. ridiculum acri

fortius et melius magnas plerumque secat res.

illi scripta quibus comoedia prisca viris est

hoc stabant, hoc sunt imitandi:

(So it is not enough to make the listener grin from ear to ear - and yet there is also some merit in that. One needs brevity, in order for the train of thought to run on, and not to get entangled with words that overwhelm exhausted ears. You also need a style which is sometimes severe, often playful, sustaining the role, now of orator and poet, from time to time that of the sophisticated 
wit, who reserves and weakens the strength of his speech on purpose. Humour very often decides important issues more forcefully and better than stinging severity. The writers of Old Comedy were successful in this [brevity and variety], and in this they must be imitated) $)^{301}$

Horace argues in this passage that there is nothing wrong with humour, although it should not be the only feature of the poem. He considers two other qualities essential for good poetry, which Lucilius' work lacks, that is: brevitas and varietas. Brevity guards against jumbled thoughts and tired listeners and variety makes that the listener's attention will be held. In the words of Freudenburg $(1993,101)$ variety is lacking in Lucilius' work, because he "is too much given to the grand style (tristi sermone) of the epic poet and rhetor, and too little adept at the restrained humorous mode (iocoso sermone) of the educated wit." ${ }^{302}$ The passage S.1.10.7-17 can be understood in a limited sense, namely that Horace sketches the stylistic qualities for satire, but it looks to me that Horace charts in those lines attributes which apply to several genres of poetry, in some of which he is already actively engaged. Horace uses in line 17 emphatically hoc (this) twice relating to all the stylistic qualities mentioned in lines 9-15: in short brevitas and varietas. In other words, Horace sees as standards of good poetry sharply worded thoughts and variety of presentation. The poets of Old Comedy possessed those. Lines 16-17 have an additional significance, that is not stylistic. Horace also refers back in S.1.10.16-17 to the opening lines of the fourth sermo when he uses the same words (comoedia prisca viris) in both S.1.10.16 and in S.1.4.2. Thus, he reminds us in S.1.10 of a third quality in which the poets of Old Comedy were successful: the example set by the poets of Old Comedy in censuring people and groups freely, with libertas (freedom of speech), which is the essence of S.1.4.1-5. ${ }^{303}$ This third quality should be copied too.

Thus, S.1.10.7-17 is the second echo in S.1.10 of S.1.4 (after the one in S.1.10.1-4). Horace restates in this second echo his view on the characteristics of good poetry. Those include stylistic aspects, brevitas and varietas, matters of content, and libertas in the choice of subject-matter for censure and in the freedom with which the censure is carried out. I do not take for granted that Horace meant to say in S.1.4 that the examples set by the men of Old Comedy should be restricted to satiric poetry. In my discussion of S.1.4.38-62, I looked at his views with respect to ingenium and ars, res and verba, and also at issues from general classic literary theory like the anticompositional theory and metathesis and at one of the concepts as treated by

301 The renderings of risu diducere rictum/ auditoris in lines 7-8, and of sententia in line 9 are by Gowers (2012, 313; 314).

302 For variety as a quality in any literary genre, see also Freudenburg (1993, 180-184).

303 Conform Freudenburg (1993, 102): “The scholiast correctly regards the claim at line 17, "in this they [the Old Comic poets] are to be imitated,'as a stylistic tenet.” Freudenburg does not discuss the observation that comoedia prisca viris in S.1.10.16 refers to the success the poets of Old Comedy had in censuring. 
Philodemus, parrhesia. ${ }^{304}$ In my opinion, Horace did not write about those issues in S.1.4 from the perspective of satiric poetry, but rather from that of poetry in general. Therefore, I suggest that the same holds for the issues raised in S.1.10.1-17, that is, that this passage represents Horace's view on poetry in general. S.1.10 does not redefine the literary position of Roman satire after Horace, but defines indeed Horace's own literary position: with respect to style and with respect to content and freedom of speech. I will explain my view in detail below after I have discussed S.1.10.48-49.

Next, Horace sneers in S.1.10.17-19 at Hermogenes and an anonymous aper, immediately followed by a long passage in lines 20-35 in which he speaks up for linguistic purity, condemning the inclusion of Greek words. First, I will look at lines 17-19:

\author{
quos neque pulcher \\ Hermogenes umquam legit, neque simius iste \\ nil praeter Calvum et doctus cantare Catullum. \\ (neither the pretty Hermogenes, nor that aper trained to recite Calvus and Catullus ever read \\ them [the poets of Old Comedy])
}

Horace disliked Hermogenes very much and saw him as an empty-headed playboy, who could not be expected to have ever read Aristophanes and the poets of Greek Old Comedy. On grounds of S.1.10.17-19, scholars argued that Hermogenes was a Neoteric and a follower of Catullus and Calvus. The latter, however, had attacked Hermogenes in the past and thus it is unlikely that Hermogenes was a supporter of him; this is indirectly reported by CIC.Fam.7.24.1 and by Porphyrio (at S.1.3.1). ${ }^{305}$ Scholars resolved this issue by concluding that Horace writes in $S .1$ about two different men: Tigellius and a second man called Hermogenes. ${ }^{306}$ Freudenburg $(1993,170)$ points out that there is no need for "a second, otherwise unknown, Tigellius." I concur with Freudenburg's $(1993,169)$ point that the argument for two different men is generally build upon the assumption "which has never really been challenged, that the passage just quoted [S.1.10.17-19] proves the Hermogenes of Satires 1.10 a Neoteric, yet the lines in question claim only that Hermogenes never read the Old Comic poets. It is the unnamed 'ape,'

304 For the issue of the unity of ingenium (talent), ars (skill), res (content) and verba (style), see also Oberhelman \& Armstrong (1995, 249-254).

305 Cicero relates in Fam.7.24.1 that the addressee (M. Fabius Gallus) had been hard at work on an issue concerning Tigellius (= Hermogenes). Cicero mentions that in his opinion the latter was condemned in the past sharply by Calvus in a bitter biting poem in the style of Hipponax (eumque addictum iam tum puto esse Calvi Licini Hipponacteo praeconio). Porphyrio (Meyer, 1874, 199) in his commentary of S.1.3.1 writes: at Licinius Caluus de eodem Hermogene loquens Sardum dixit Sardi Tigelli putidum caput uenit (and Licinius Calvus speaking about the same Hermogenes as Sardinian said that the stinking head of the Sardinian Tigellius comes).

306 For the identities of Tigellius and Hermogenes, see note 91, and my discussions of S.1.2.1-3 and S.1.3.129-130. 
[...] not Tigellius, who is accused of 'singing' only the works of Calvus and Catullus.” There is in addition to Freudenburg's point a second argument: Horace's focus in S.1.10.7-19 is his view on standards of good poetry, which I mentioned above, namely brevitas, varietas, and libertas. Lines 17-19 close this passage before considering a new subject, that is the mixing of Greek and Latin. Hermogenes is specifically mentioned by Horace as one who does not meet his standards. He is the opposite of a Neoteric, as he was "noted for his flamboyant amplification against the reverse extreme of strict Neoteric brevity" (Freudenburg, 1993,170). However, I cannot go along with the conclusion that Horace in S.1 writes about one Tigellius only. Freudenburg's suggestion does not explain the opposition between the funeral of a Tigellius in the second sermo and a Hermogenes (Tigellius) who is very much alive in the tenth.

Thus, I accept the solution of DuQuesnay $(1984,56)$, which addresses the incompatibility between the funeral of a Tigellius in the second sermo along with his appearance in the third at S.1.3.1-13. At the same time, the option I prefer does not hinge on the assumption that Hermogenes was a Neoteric. In my view, the dead Tigellius of S.1.2 is Marcus Tigellius Hermogenes, whom Porphyrio describes in his commentary on S.1.2.1-3, namely the musician of Julius Caesar's household, and later of that of Cleopatra and whom Augustus also liked. He died presumably in 40 or 39 B.C. The other man is the living Hermogenes of S.1.3.128-133, 1.4, 1.9 and 1.10, who was also a Sardinian and who defected in 38 or 37 B.C. to Sextus Pompey, who in the summer of 39 B.C. retained control over Corsica, Sardinia and Sicily. The islands were well-known as recruiting areas for Sextus. In addition, the name of Hermogenes suggests that he was a freedman, and it is known that Sextus recruited many followers from those (see also note 160). I differ from DuQuesnay $(1984,56)$ that it was the dead Tigellius "who would have been singled out for extensive criticism." The defection of Hermogenes to Sextus made him the target of Horace's criticism. In order to differentiate clearly between the two, when I write Tigellius I refer to the dead man of S.1.2 and when I write Hermogenes I refer to the living man. This does not apply in the case of a translation from the Latin.

The other man mentioned, who apes Calvus and Catullus cannot be identified, but refers most likely to somebody whose knowledge and pursuit of poetry does not go beyond Calvus and Catullus. The words in lines 18-19 are a condemnation of the aper, and not of the two poets. Yet, Horace refers presumably intentionally to the neoteric poets Calvus and Catullus. Both poets wrote anti-Caesarian lampoons, but both were eventually reconciled with Julius Caesar, as recorded by Suetonius (SUET. Jul.73). We can only guess at the reason why Horace bracketed the three poets and the aper in lines 17-19. In my view, it is not likely that he held the same low opinion of Calvus and Catullus as we know he did of Hermogenes and apparently also did of the aper. We are not informed of the details of Horace's professional relationship with Calvus. He did not object to Catullus' poetry in the same manner as he did to that of Lucilius, although he rejected the more decadent facets of Catullus' poems and 
postured himself more reservedly in matters of love. ${ }^{307}$ Contrary to Catullus, he was also more restrained in his criticisms. Wiseman $(1988,132)$ points out that Catullus' "obscene abuse of Piso, Memmius and Caesar was as unrestrained as Lucilius' attacks on Scaevola, Lentulus and Metellus, and delivered with equal impunity." Wiseman states that Horace was more inhibited than both Catullus and Lucilius because Horace feared that his victims would go to law if he offended them too much, and because Horace's inferior social position compared to Lucilius and Catullus also played a part. In my opinion, Lucilian types of attack were out of place in $S .1$ as Horace himself mentioned at several occasions. I explained that this was because he wrote $S .1$ as a collection of poems aimed at self-presentation. In addition, there is also a political aspect to Horace's commentary, as I noted in my introduction to the passage S.1.10.539. It seems to me that Horace expresses in lines 17-19 a wish to keep his distance from the four men (the three named and the aper) because at least Calvus and Catullus had a well-known history of disturbed relations with the Caesarian faction caused by their anti-Caesarian invectives in the past. It is likely that Horace, who tries in S.1 his hardest to prove that after his association with Brutus he can turn into a reliable member of Maecenas' circle, wants Maecenas to appreciate that the two men may not have shaken off their political past in the same way as he has. Horace may have had still a second reason not to commit himself too much concerning Catullus. When I discussed in section 2.1 the influence of Greek iambus on Horace, I mentioned that it is likely that the latter knew of Maecenas' sympathy for Catullus' poetry. According to Watson $(2003,19)$ two remaining fragments of poems by Maecenas addressed to Horace (fragments 2 and 3, Courtney, 2003) contain "explicit echoes of Catullus." Thus, Horace may have thought it prudent not to be too critical of Catullus' antiCaesarian views. It follows on grounds of DuQuesnay's $(1984,56)$ suggestion that the Sardinian Hermogenes defected to Sextus Pompey in 39 B.C. that Hermogenes could not be trusted anyway. This would also explain why Hermogenes in S.1.10.7980 is linked to a silly Fannius (ineptus Fannius), who may be C. Fannius, an adherent of Sextus. Thus, a potential association of the three men with Maecenas and his company was fraught with difficulties.

307 For Horace and Catullus, see Freudenburg (1993, 169); Heyworth (2001); Putnam (2006); Quinn (1963, 141-148, esp. 146-148); Wiseman (1988, 132-133). Gowers (2012, 317) referring to Putnam (2006) states that Catullus' "relationship with H.[orace] is ambiguous [...]: they share a similar literary aesthetic.” Putnam (2006), traces indeed Catullus' presence in Horace's poetry, but finds this especially in his lyric poetry, the Carmina. Although Putnam $(2006,5)$ states: "whether we are dealing with matter or manner, with mode of presentation or with content, Horace seems to have set no limits on the aspects of Catullus to which he was drawn," we find only the single reference $(2006,60)$ to the Sermones: the bore of S.1.9. Putnam mentions this one example from the Sermones when he discusses Horace's ability "to reveal much about characters of whose names we remain ignorant." In my view, Putnam did not address the question of Horace "sharing a similar literary aesthetic" with Catullus in the Sermones. 
Horace introduces a new subject for criticism of Lucilius, and begins the passage devoted to the mixing of Greek and Latin words quoting someone defending the habit in lines 20-21: 'at magnum fecit quod verbis Graeca Latinis/ miscuit.' ("but it was a great achievement the way he [Lucilius] mixed Greek words with Latin.”). ${ }^{308}$ Although good poetry relies to a high degree on variety, Horace is of opinion that Lucilius was too unrestrained with his Grecisms. ${ }^{309}$ He does not condone mixing Greek and Latin in Pitholeon's poetry either. Horace's rejection of the interlocutor's defence of the quality and poetic value of Grecisms is given in lines 21-23:

\section{o seri studiorum! quine putetis \\ difficile et mirum, Rhodio quod Pitholeonti \\ contigit?}

(Such late learners! Do you really think that it is difficult and surprising what Pitholeon of Rhodes achieved?)

The suggestion that the name Pitholeon was a Greek-Latin mix for metric reason from Pitholaus to Pitholeon $(\pi i \theta \omega v=$ ape + oleo $=$ I smell of $)$ is attractive. ${ }^{310}$ This also suggests the likely identity: the wit M. Otacilius Pitholaus (first century B.C. - after 45 B.C.), who came to Rhodes for study and went native. Horace pokes fun at his interlocutor: no wonder he mixed Greek and Latin. The change in name also exemplifies "the humorous possibilities of such a change" (Freudenburg, 1993, 169 note 101). Pitholaus, however, wrote a eulogy of Pompey and lampooned Julius Caesar (see SUET.Jul.75) ${ }^{311}$ It is not clear whether he was one of the Neoterics as well. But it is feasible that Horace - as in the cases of Laberius, Calvus and Catullus - is also antipathetic of Pitholaus on grounds of his history of lampooning Julius Caesar. In addition, there may be a second reason for Horace's rejection of Grecisms, one of a political nature. We saw that he in S.1.8 alluded to the pressure from the East, that is Parthia and Egypt. This was not only military, but also culturally. He was concerned about the future resilience of Rome and the loss of traditional values. We will see below that Horace broaches again the subject of Romans writing Greek in S.1.10.3135, where he relates that Quirinus, the deified Romulus, once forbade him to fill up the crowded Greek ranks ('magnas Graecorum malis implere catervas') of poets (line 35). Although Quirinus' interdiction does not refer to the mixing of Greek and Latin, but to the writing of verses in Greek, the allusion to the god is relevant. It was not

308 For the mixing of Greek and Latin in S.1.10, see Freudenburg (1993, 166-168).

309 Conform Gowers (2012, 318): "Lucilius was indeed lavish with satirical Grecisms."

310 For the name Pitholeon, see Freudenburg (1993, 169); Gowers (2012, 319); Rudd (2007, 120; 147).

311 For M. Otacilius Pitholaus, see Kaster (1995, 297-299). For Pitholaus lampooning Julius Caesar, see Frank (1925, 74 note 6). Conform Rudd (2007, 120): "Frank is [...] probably right about Pitholaus - if we accept the usual identification of Pitholeon ([line] 22) with Pitholaus.” For Horace and the Neoterics, see Freudenburg (1993, 163-173); Rudd (2007, 119-121). 
"his father," or a colleague poet, or Maecenas who advised him, but the guardian of Roman values, Quirinus himself, who ordered him to write Latin verse. This signifies that Horace felt obviously very strongly about resisting the penetrating Greek cultural influence, also in his own domain, and that he saw the growing domination of foreign culture as a loss of being Roman. ${ }^{312}$

Horace's negative opinion about the mixing of Greek and Latin seems to be inconsistent with his words in S.1.4.8, in particular with his criticism of Lucilius' lack of refinement in the composition of his verses. In S.1.10.23-24 Horace's interlocutor says that blending the Latin with Greek words introduces a more refined composition, similar to the mixing of Latin Falernian with Greek Chian wine. Lines 23-24 read: 'at sermo lingua concinnus utraque/ suavior, ut Chio nota si commixta Falerni est' ("but a style which blends both languages is sweeter, as when Falernian wine is mixed with Chian"). Horace argued in S.1.4 that Lucilius should use a more refined style, but he does not agree that a more refined composition is created by introducing the "sweeter" sounds of foreign Greek words. This is consistent with the criticism he levelled against Lucilius in S.1.10.20-24 using the Greek. Horace rejected the anticompositional theory as supported by the Stoics, who favoured a rugged word order. Eliminating the ruggedness would not be achieved by the introduction of foreign words. This view was compatible with his view that the Latin language and Roman culture needed to be protected..$^{313}$

Next, Horace considers in lines 25-30 the issue of mixing Latin with Greek in the legal profession. He changes in line 25 from the use of Greek in poetry to that in oratory. $S .1 .10 .25-30$ reads:

cum versus facias, te ipsum percontor, an et cum

dura tibi peragenda rei sit causa Petilli?

scilicet oblitus patriaeque patrisque, Latini

cum Pedius causas exsudet Publicola atque

Corvinus, patriis intermiscere petita

verba foris malis, Canusini more bilinguis?

(Does this rule hold good, I ask you, only when one writes verses, or also when one has to fight the hard case of the defendant Petillius? Obviously, when Pedius, Publicola and Corvinus sweat out their cases in Latin, one would like them to completely forget fatherland and father mixing native with foreign words, like a bilingual from Canusium, wouldn't one?) $)^{314}$

312 For the defence of Latinitas, see Gowers (2012, 318).

313 For anticompositional theories and the views of the Stoics, see my discussion of S.1.4.9-13 in section 2.2.2 and note 135 .

314 In line 27 I follow contrary to OCT Bentley (1711) w.r.t oblitus/oblitos, as I think Bentley’s reading makes better sense within the context; see also Gowers (2012, 320). I follow Gowers (2012, 320) w.r.t Latine/Latini. 
Petillius in line 26 is Petillius Capitolinus, whose trial is mentioned in S.1.4.93-100. Porphyrio reports that he stole the gold crown of Jupiter Capitolinus, when he was in charge of the temple, but was acquitted by Julius Caesar; the story is probably an invention, and it is more likely that he was accused of embezzlement. But, his trial was presumably very much in the public eye, the more so as Petillius was well-born and belonged to the political elite. I concur with Knorr's (2005) arguments that Pedius and Publicola are probably two distinct individuals and that Corvinus is M. Valerius Messalla Corvinus, a military man, and also a patron of the literary; Ovid and Tibullus moved in his circle and according to $\operatorname{Knorr}(2005,397)$ "he was considered to be one of the best speakers of his time and a notorious stickler for pure Latin" (see also note 45). ${ }^{315}$ Canusium in Apulia was originally a Greek settlement, whose inhabitants spoke Greek and the local Oscan dialect and also (some?) Latin.

The answer to the rhetorical question in the above passage is that one would like to see the orators in public appearances, like for example members of the Senate and lawyers in court, speak correct and pure Latin. If this were not the case, Roman culture would be seriously eroded. Thus, Horace's rejection of the unacceptable mixing of Greek and Latin in formal and public rhetoric is consistent with his previous repudiation of the practice in poetry. My view is contrary to that of $\operatorname{Knorr}(2005,398)$, who argues that "Messalla would not be the best person to appeal to for support. Messalla insisted on pure Latin in his prose, but he had no qualms about writing Greek poetry himself." ${ }^{316}$ However, Horace's point is about the mixing of Greek and Latin, and not about a Latin speaker, like Messalla, writing Greek poetry. On account of what Quirinus forbade Horace to do in S.1.10.31-35, namely writing Greek verse, Horace and Messalla would presumably agree to differ on that point. But, both Messalla and Horace rejected presumably the mixing of Greek and Latin in a text, prose or poetry.

He returns in S.1.10.31-35 to the subject of the function of the Greek language in writing poetry after his reflections upon the function of Greek in writing prose. He narrates a "personal experience," that is a dream he claims he once had. In lines 31-32 he asserts that he also once wrote little verses in Greek like Messalla (atque ego cum Craecos facerem,[...],/ versiculos), although he was also born on this side of the Adriatic sea (natus mare citra), again like Messalla and also like the bilingual from Canusium. We saw already that Quirinus appeared after midnight, a vital hour as dreams at that time come true and forbade him to write verses in Greek (vetuit me tali voce Quirinus,/ post mediam noctem visus cum somnia vera) (lines 32-33). Quirinus

315 For Petillius Capitolinus, see Brown $(2007,135)$ and the discussion at S.1.4.93-100. For Pedius and Publicola, see Knorr (2005, 397): "Pedius is probably identical with the Q. Pedius who served as quaestor urbanus in 41 B.C.E.,” and Publicola is "L. Gellius Publicola (cos. 36 B.C.E., the year before the publication of Satires I) is known primarily as a soldier and politician.”

316 Italics are mine. 
actually said to Horace in the dream in lines 34-35: "it would be crazier than carrying timber to the wood, if you chose to fill up the crowded Greek ranks [of poets]" ("in silvam non ligna feras insanius ac si/ magnas Graecorum malis implere catervas'). The expression in Latin that something "is as crazy as carrying timber to the wood," is equivalent to the English "as crazy as taking coal to Newcastle” or the Dutch "as crazy as bringing water to the sea." I have explained above that I read those lines about the lack of linguistic purity as Horace's statement about the regrettable growth of Eastern influence in Rome and the need to resist the penetrating Greek cultural influence on Latin literature.

The last victim of Horace's criticism of past and recent poets and literary modes is turgidus Alpinus (the inflated man of the Alps) in S.1.10.36-39. Porphyrio identifies turgidus Alpinus as M. Furius Bibaculus of Cremona, who returns in S.2.5.41. ${ }^{317}$ Furius Bibaculus, a Neoteric poet of the first century B.C., wrote an epic Annales Belli Gallici about Julius Caesar's campaigns. It is not clear whether he also wrote a second epic, an Aethiopis, about Memnon, the son of Aurora, who was killed by Achilles in the Trojan war. None of his works is extant. The identification of turgidus Alpinus depends much on the two references by Horace in S.1.10.36-37, namely on iugulat Memnona (he murders Memnon) referring to the lost epic Aethiopis, and on defingit Rheni luteum caput (puts into shape the muddy head of the Rhine) referring to the also lost Annales Belli Gallici. Both references are seen as sarcastic disparagements of Bibaculus' poetry by Horace. The validity of the identification is controversial. On the one hand, according to Freudenburg (1993, 103 note 82) "the identification of Turgidus Alpinus

317 For the identification of turgidus Alpinus by Porphyrio as M. Furius Bibaculus the following is relevant. Porphyrio (Meyer, 1874, 240) refers in his commentary on S.1.10.36 to Memnon, which is understood as an allusion to Bibaculus' Aethiopis. Porphyrio's commentary reads: “turgidus Alpinus iugulat dum Memnona: hexametris uersibus nimirum describit. et belle 'iugulat Memnona' dilogos

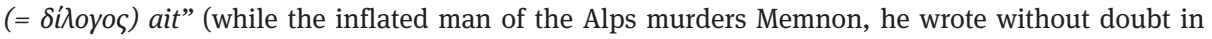
hexameters. And falsely he said "he murders Memnon”). Horace also writes about Furius (Bibaculus) in S.2.5.41: "Furius hibernas cana nive conspuet Alpis" (Furius spat white snow upon the wintry Alps). Porphyrio (Meyer, 1874, 263) wrote as commentary on this line: "Furius hibernas cana niue. hic uersus Furi Bibaculi est. ille enim cum uellet Alpes niuibus plenas describere, ait Iuppiter hibernas cana niue conspuit Alpes" (Furius: wintry with white snow. This line is by Furius Bibaculus. For when Furius wanted to describe the Alps full of snow, Furius said Jupiter spat white snow upon the wintry Alps). Within the context of a discussion of extravagant metaphors, Quintilian also refers in Inst.8.6.17 to this line without mentioning M. Furius Bibaculus by name. QUINT.Inst.8.6.17 reads: Iuppiter hibernas cana nive conspuit Alpes (Jupiter spat white snow upon the wintry Alps); the commentary in Russell $(2001,435)$ states that this line is by "Furius Bibaculus. fr. 15 Courtney $(2003,198)$." Further, QUINT.Inst.10.1.96 refers to Bibaculus: iambus non sane a Romanis celebratus est ut proprium opus, quibusdam interpositus: cuius acerbitas in Catullo, Bibaculo, Horatio [...] reperiatur (iambic has not been particularly practised by Romans as a separate genre, but by some included in other metres: one finds its bitterness in Catullus, Bibaculus and Horace). For the identification of turgidus Alpinus, see Freudenburg (1993, 103); Gowers (2012, 323); Nisbet (1995, 393-395); Rudd (2007, 289-290); Gundel (1967). 
(1.10.36) with M. Furius Bibaculus seems the best option given the similarities between Satires 1.10.36 and Horace's jibe against Furius, also a writer of historical epic, at Satires 2.5.39-41." On the other hand, Rudd (2007, 289-290 note 52) states "so one turns without much confidence to the view that Horace's Furius was contemporary with but distinct from Bibaculus." A further relevant point made about Bibaculus is a line in TAC.Ann.4.34 (Goelzer, 1959, 197) that carmina Bibaculi et Catulli referta contumeliis Caesarum leguntur: sed ipse diuus Iulius, ipse diuus Augustus et tulere ista et reliquere (the poems of Bibaculus and of Catullus, which are filled full of invectives against both Caesars, are still read: yet even the deified Julius himself and also the deified Augustus tolerated them and left them in peace). This can be considered supportive of the identification of turgidus Alpinus as Furius Bibaculus, as all other poets whom Horace censures in S.1.10.5-39 are known to have written lampoons against Julius Caesar: Laberius (line 6), Calvus and Catullus (line 19), and Pitholaus of Rhodes (line 22). Horace repeats with his functional reference to Furius Bibaculus the political statement about his condemnation of the poets who lampooned Julius Caesar that he made before.

Yet, whatever the identity of turgidus Alpinus may be, it is clear that Horace did not rate his epic highly. He put it quite plainly in line 36 that he condemned his style: the sarcastic turgidus (inflated, pompous) and iugulat Memnona (he murders Memnon). The latter qualification reminds me of S.1.4.59-62, when Horace raises the subject of metathesis and asserts that rearranging verses is like murdering the poet: praeponens ultima primis,/ non, [...]/ invenias etiam disiecti membra poetae (placing last things before first, [...] you would not find the limbs even of a dismembered poet). ${ }^{318}$ Turgidus Alpinus rearranged perhaps an existing epic about Memnon and did not care that he created inadmissible changes to the meaning of the Memnon story.

Contrary to the pompous Alpinus, Horace pretends in lines 37-39 that he only writes trivial poetry for his own pleasure. $S .1 .10 .37-39$ reads:

haec ego ludo,

quae neque in aede sonent certantia iudice Tarpa, nec redeant iterum atque iterum spectanda theatris.

(I play about with these, which are neither to be heard in the Temple [of the Muses] striving for Tarpa's adjudication, nor to come back again and again to be seen in the theatres) ${ }^{319}$

Tarpa is Maecius Tarpa, who was appointed in 55 B.C. by Pompey as adjudicator of literary competitions. Horace's words show of course not only his false modesty, but are also a rejection of the struggle for attention by the poets discussed in this section.

318 For metathesis, see also my discussion of S.1.4.59-62.

319 Porphyrio's commentary on aede in line 38 is: in aede Musarum, ubi poetae carmina sua recitabant (in the temple of the Muses, where poets recited their poems). 
Horace's attitude is also in line with his other statements about his desire for privacy, as for example in S.1.6.122-123 and in the opening lines of S.1.9, and his denial of publicity for his poetry. Horace will testify in S.1.10.73-74 that he does not attempt to reach large audiences, and about twenty five years later he still held the same opinion. He stated in his Epistula ad Augustum (Ep.2.1.214) again his preferred option asking Augustus to look favourably on his art, which is poetry for private reading: lectori credere (to put themselves in a reader's hands). In his earlier Ep.1.19, written between 23 and 19 B.C., he expressed similar feelings. At the end of his life when he wrote his Ars Poetica, he again poured scorn on the writing for large audiences and showed himself dismissive of the taste of large crowds either in the theatre or in someone's townhouse.

Then, in the passage S.1.10.40-49, Horace focuses his attention on contemporary poetry, his fellow poets. He begins with his friend Gaius Fundanius, a comic poet of the New Comedy, who features prominently in S.2.8, and who also belonged to the circle of Maecenas (see note 45). ${ }^{320}$ According to Gowers $(2012,325)$ Horace praises Fundanius because he had "the good taste to imitate elegant Terence, not sloppy Plautus (cf. Ep.2.1.58-59, AP 269-271), though his characters' names are still Greekderived." Horace demonstrates this in lines 40-41 using Terentian names: Davus is "a cunning slave in Ter.Andria [...] and Chremes is the duped father in Ter.Phormio" (Gowers, 2012, 325). S.1.10.40-42 reads:

arguta meretrice potes Davoque Chremeta

eludente senem comis garrire libellos

unus vivorum, Fundani;

(you alone of those living, Fundanius, can chat in congenial scripts, where a sly courtesan and Davus make sport of old Chremes)

Note how cleverly Horace, using eludere (to make sport of) in line 41, refers back to his own ludere (to play about) in line 37, suggesting that Fundanius and he are partners in writing with a light touch.

Next, in S.1.10.42-43, he addresses C. Asinius Pollio (76 B.C. - A.D.4), a military man, consul in 40 B.C., and retired from politics soon afterwards. He was a committed Republican and a supporter of Julius Caesar. It is likely that he was involved in the land expropriations in Northern Italy after Philippi (see also note 122). He was also a literary critic, author of a historical work and poet of tragedies and founder of the first public library in Rome. Gowers $(2012,326)$ notes that Pollio "upheld H.[orace]'s criteria of Latinitas and urbanitas." 321 HOR.Carm.2.1 is dedicated to Pollio's History of the Civil Wars. In S.1.10, Horace lauds Pollio as the "acknowledged [living] master

320 For Gaius Fundanius, see Rudd (2007, 95): "When Horace began his career as a poet the main genres were capably represented: Virgil was writing pastoral, Fundanius comedy, and so on." See also Harrison (2015, 41-42); Rudd (2007, 217-220; 222).

321 For C. Asinius Pollio, see also Gundel (1964). 
of his genre, tragedy," with the following words: Pollio regum/ facta canit pede ter percusso (Pollio sings the deeds of kings in iambic trimeters). ${ }^{322}$

The next poet in this line-up of famous poets is L. Varius Rufus (ab.70 - ab.15 B.C.), poet in the epic genre, of whom Horace narrates in S.1.6.55 that he was introduced by him and Virgil to Maecenas and to whom Horace refers as one of his friends in S.1.5.3944, during the journey to Brundisium, and in S.1.9.23, during his unfortunate stroll along the Via Sacra with the pushy fellow. His tragedy Thyestes was enacted in 29 B.C. at the games after Actium. ${ }^{323}$ Horace does not refer to the latter in S.1.10.43-44, and as the Thyestes is his only extant work, that was not yet produced at the time, Horace refers obviously to an earlier work of Varius that is unknown to us. Lines 43-44 read: forte epos acer/ ut nemo Varius ducit (Varius, spirited like nobody else, composes vigorous epic). Virgil is then praised in S.1.10.44-45 for his Eclogae, pastoral poetry with commentary on Octavian's land confiscations in Northern Italy after Philippi. He showed himself in the Eclogae very concerned about the disappearance of the small farms and voiced his compassion with the suffering smallholders. Horace writes: molle atque facetum/Vergilio adnuerunt gaudentes rure Camenae (the Muses relishing the countryside have granted to Virgil tenderness and elegance). Horace also used the word facetus in S.1.4.8, which I (and many others) translated as "witty" (see above at the introduction of this analysis of S.1.10). For S.1.10.44, the meaning of "elegance" for facetum is also given by QUINT.Inst. 6.3.19-20. This fits the context of the Eclogae better than for example "charm." Horace wants to demonstrate with the words molle, which I take to mean in S.1.10.44 "mild, tender," and with facetum his approval of Virgil's way of showing his compassion by means of the very refined images and imaginative allusions in the Eclogae. ${ }^{324}$ This concurs very much with my own view of the Eclogae, and I feel honoured by Horace's endorsement of my view, that the Eclogae show on the one hand Virgil's critical concern with the future of the countryside and on the other his compassion with the farmers.

322 Conform Brown (2007, 188): "Pollio: in the context of unus vivorum 42 and ut nemo 44, the acknowledged master of his genre, tragedy (indicated by the subject-matter regum facta)."

323 For L. Varius Rufus, see also Schmidt (1975a).

324 QUINT.Inst.6.3.19-20 (Butler, 1977, 448-449): Facetum quoque non tantum circa ridicula opinor consistere. Neque enim diceret Horatius, facetum carminis genus natura concessum esse Vergilio. Decoris hanc magis et exultae cuiusdam elegantiae appellationem puto (I also do not think that facetus only inheres in texts which excite laughter. If so, Horace [in S.1.10.44-45] would certainly not have said that nature had granted Virgil a facetus character in his verses. I think that in this case the word is rather used for something of grace and joyful elegance). Italics are mine. For the details of my reading of Virgil's Eclogae, see Weeda (2015, 54-84). My rendering of molle (tenderness) is contrary to Zetzel (2006, 46): "molle, however, is less unequivocally positive: despite all the favourable connotations [...], it also may have overtones of decadence and effeminacy.” In Zetzel (2006, 46 note 27), however, he states: "The interpretation of Putnam (1995) 305-6 takes molle as unequivocally positive, as many critics." 
After Virgil, it is in S.1.10.46-47 the turn of P. Terentius Varro Atacinus (of Atax, 82 - 35 B.C.), born in Gallia Narbonensis; hence his cognomen which refers to the river Atax (modern Aude) in the province. We know that he translated Apollonius Rhodius' Argonautica in Latin, and that he wrote an epic called Bellum Sequanicum about Julius Caesar's campaign against Ariovistus and two didactic poems, a geographical (Chorographia) and an agricultural (Epimenides). Only a few fragments of those works have survived. Whether he also wrote Satires is a vexed question: there are no extant satires, although Horace appears to refer in S.1.10.46-49 to Varro Atacinus writing satire. Two ancient testimonies, one by Propertius and another by Ovid in the Tristia, imply that Varro also wrote elegiac love poetry, in which he among other matters sang of a girl called Leucadia. PROP.2.34.85-86 reads: sic quoque perfecto ludebat Iasone Varro/ Varro Leucadiae maxima flamma suae (Varro also sported those when he completed his tale of Jason. Varro who was the brightest flame of his Leucadia). OV.Tr.2.439-440 reads: is quoque, Phasiacas Argo qui duxit in undas, non potuit Veneris tacere suae (he, too, who guided the Argo to the waters of the Phasis [a river in Colchis] could not pass over his own love affairs in silence). The words "he, too, who guided the Argo to the waters of the Phasis" is understood as referring to Varro Atacinus' translation of the Argonautica, and not to the original by Apollonius Rhodius. This interpretation is reinforced by the context of Ovid's line, where the man who guided the Argo is placed among a number of Roman elegiac poets. OV.Tr.2.421-422 reads: neve peregrinis tantum defendar ab armis,/ et Romanus habet multa iocosa liber (I should not defend myself with foreign arms [foreign/Greek writings] only, as Roman books also contain much frivolity). Then, Ovid mentions, among many other examples, Catullus who sang of Lesbia and his loves abroad, Calvus who revealed his own adventures, Gallus and Lycoris, and Tibullus. Some scholars ascribe satiric poetry to Varro; they do this, however on grounds that look to me rather dubious. For example Schmidt (1975b, 1140) writes that Varro's "production contains [...] Satires (HOR.S.1.10.46), in which he among others sang of - like Lucilius' Collyra - a beloved under the pseudonym of Leucadia (PROP. 2.34.85f, OV.Tr. 2.439f)."325 Although the testimonies by Propertius and Ovid lead me to the conclusion that Varro wrote elegiac rather than satiric poetry, S.1.10.46-49 suggests that Varro wrote indeed satires. As these appear to be completely lost, the question remains probably unresolved. S.1.10.46-49 reads:

hoc erat, experto frustra Varrone Atacino atque quibusdam aliis, melius quod scribere possem, inventore minor; neque ego illi detrahere ausim haerentem capiti cum multa laude coronam.

325 For P. Terentius Varro Atacinus, see Schmidt (1975b). The German text of Schmidt (1975b): Varro’s “produktion umfaßte [...] Satiren (Hor.s.1, 10, 46), in denen er u.a. - vgl. Lucilius' Collyra - eine Geliebte unter dem Pseudonym Leucadia besang (Prop. 2, 34, 85f. Ov.trist. 2, 439f.).” For the text by Propertius, see Schuster $(1914,89)$. 
(this kind of writing, which had been tried in vain by Varro of Atax and some others, was what I could do better, although not as well as its inventor; nor would I presume to take from him the crown that remains attached to his head with so much glory)

If hoc in line 46 looks backward it can only refer to satire if Horace had first-hand knowledge of Varro of Atax's satiric writing, which has since completely disappeared. If hoc looks forward, "this kind of writing" refers without question to satire in view of what follows in lines 48-49 (inventore etc.) and the context of the whole passage of lines 50-71; both I will discuss presently. Further, we may safely assume that Horace's first-hand knowledge of Varro's production was far superior to ours today.

According to S.1.10.46-47, Horace obviously did not rate Varro of Atax's achievements in satiric poetry and those of some others highly. An interesting question is whether he includes among the "some others" Varro's namesake M. Terentius Varro from Reate, who wrote four books of verse satire and one hundred and fifty of Menippean satire. Still, Horace could do better, although not as well as its inventor Lucilius (melius quod scribere possem,/ inventore minor). Horace makes an important statement in lines 48-49: he does not presume to take the crown of satirical poetry from Lucilius. Gowers $(2012,328)$ describes those two lines as "a mock-deferential bow from the inheritor to the inventor of satire." I interpret Horace's words that he does not want to be the inheritor, but that he bows out of satiric poetry.

In connection with Horace's statement that he does not intend to be a writer of satire, it is useful to summarize Horace's position with respect to his ideas about standards of good poetry. We saw above at the discussion of S.1.10.1-17 that Horace does not define in S.1.10 his position with respect to satiric writing, but that he defines his position with respect to style and content of his poetry in general. He was already writing or would soon commence to write in at least two additional genres simultaneously with the writing of S.1 and S.2: Epodi in the iambic genre, and the lyric poetry of many Carmina (Odes). According to Nisbet and Hubbard (2001, xxviii) "it would be rash to assume that the epodes were finished before the odes were begun." The same can be argued for the Sermones and the Carmina. Many of the carmina of the first book were written before 30 B.C. ${ }^{326}$ As he intends to write his political commentary in different genres, he cannot afford to restrict his views on his poetic orientation to one genre only. I noted in my introduction to the discussion of S.1.4.3-5 that, although Horace accepted that the genre of satire should hold wrong-doers freely and openly to reproach, I did not find that Horace ever addressed in S.1.1-1.3 wrong-doers directly, either in a mild or an agonistic Lucilian fashion. I conclude at the end of S.1 that

326 For the dating of Epod., see note 7. For the dating of the poems in Carm.1, see Nisbet \& Hubbard (2001, xxvii-xxxvii). Acc. to Nisbet \& Hubbard (2001, xxviii-xxx) the following carmina were most likely written between 35 and 30 B.C.: 1.9, 1.11, 1.14, 1.15, 1.16, 1.18, 1.20, 1.23, 1.27, 1.35, 1.37, 2.13, and 2.17. The books of Epistulae and Ars Poetica were written after 23 B.C. For the dates of the books of Epistulae and Ars Poetica, see Ferri (2007, 121-131); Mayer (1994, 1-52). 
no satiric poetry appeared in the rest of the book. I have come to this view on the following grounds. The whole of $S .1$ (including S.1.10) is a collection of his credentials in which Horace presents himself as a worthwhile future political commentator, associated with Maecenas. I also noted in my discussion of S.1.3.29-34 that Horace considers in those lines his future style of delivering critical commentary in general: that means not in the role as the satirist, but in that as a commentator of political issues in several genres. ${ }^{327}$ S.1.3.29-34 anticipated S.1.10.46-49 in which he says that he does not intend to become the successor to Lucilius. Hence, my conclusion that the first book of Sermones does not belong to the satiric genre. Further, if Horace was the leading satirist after Lucilius who set the new standards for the genre, particularly in S.1.4 and S.1.10, it is peculiar that he never wrote any satire, neither in S.1 and S.2 nor in any other work.

Horace continues the discussion of the work of Lucilius in S.1.10.50-71 starting with a brief recapitulation of S.1.4.11-13, formulating in lines 50-51 the crux of his criticism of Lucilius' style: "but I said that his work flows muddy, and often carries more that needed to be removed than needed to be left." ${ }^{328}$ Next, he refers to Lucilius himself in order to legitimise his criticism. S.1.10.50-55 reads:

at dixi fluere hunc lutulentum, saepe ferentem

plura quidem tollenda relinquendis. age, quaeso,

tu nihil in magno doctus reprehendis Homero?

nil comis tragici mutat Lucilius Acci?

non ridet versus Enni gravitate minores,

cum de se loquitur non ut maiore reprensis?

(but I said that his work flows muddy, and often carries more that needed to be removed than needed to be left. Come, I ask you, do you, a scholar, find no faults in the great Homer? Doesn't Lucilius, obliging he may be, want to change anything in the work of the tragic poet Accius? Doesn't he laugh at lines of Ennius that want dignity, when he speaks of himself as no greater than those he criticized?)

Lucilius noted faulty details in Homer and in Ennius and the tragic poet L. Accius (170 - ab. 84 B.C.). ${ }^{329}$ Horace's point is that if Lucilius criticized the great poets, he and his followers like the Pompeians should not be offended when a "great" poet like Lucilius gets his own back (see also the discussion of S.1.4.5).

Horace works his previous criticism of Lucilius out further in the long passage that follows, S.1.10.56-71, and also places the criticism within the contemporary

327 See also my discussion of S.1.3.29-34 in section 2.2.2.

328 For a discussion of S.1.10.46-71, see also Freudenburg (1993, 179-184). I owe the rendering of plura quidem tollenda relinquendis in line 51 to Gowers (2012, 329).

329 For the Lucilius' fragments with his criticism of Homer, Ennius and Accius, see Gowers (2012, 329). 
context. In addition, he finds some mitigations for Lucilius' harsh style. S.1.10.56-64 reads:

\author{
quid vetat et nosmet Lucili scripta legentis \\ quaerere, num illius, num rerum dura negarit \\ versiculos natura magis factos et euntis \\ mollius, ac si quis pedibus quid claudere senis, \\ hoc tantum contentus, amet scripsisse ducentos \\ ante cibum versus, totidem cenatus, Etrusci \\ quale fuit Cassi rapido ferventius amni \\ ingenium, capsis quem fama est esse librisque \\ ambustum propriis?
}

(what forbids us, too, as we read the writings of Lucilius, to ask whether it was his own nature or the harshness of his subject matter which prevented him from writing verselets that were more finished and ran more smoothly; and if he were simply content with having words versified in hexameters, rather than loved having written two hundred lines before and after dinner? Like Cassius the Etruscan whose talent was more impetuous than a rushing river and who, the story goes, was cremated on top of his own books and cases) $)^{330}$

Horace recalls to mind his points of S.1.4.6-13, in which he criticized not Lucilius' content, but his style and which he closed in S.1.4.13 with the words nam ut multum, nil moror (for I am not interested in quantity), inferring that quality and subject matter should come first. He points out again in S.1.10 the lack of refinement and the verbosity of Lucilius blaming amongst other matters Lucilius' voluminous production at high speed, like Cassius the Etruscan, an unknown poet, whose output could serve as his funeral pyre. Yet, Horace raises in line 57 a new point, and the mere mention of the point shows that he tones down the criticism of Lucilius that he expressed in S.1.4. I intend to show that Horace looks more favourably on Lucilius when he goes deeply into the latter's poetry allowing for the political context of his age. ${ }^{331} \mathrm{He}$ asks whether Lucilius' lack of finish was caused by "his own nature or by the harshness of his subject matter?" I interpret the harshness of the subject matter as referring to the contemporary political context of Lucilius' writing. The question that Horace raises is whether the serious political issues of some hundred years ago and Lucilius' censure of those involved did not require an unpolished response; such reply was precisely what the malicious individuals of the past were deserving and what they understood. Horace suggests in the following passage S.1.10.64-71 that Lucilius would have written

330 For lines 57-60 (quaerere ... contentus) I used Gowers’ (2012, 330) rendering.

331 Conform Freudenburg's $(1993,179)$ statement : "In Satires 1.10, the satirist's tone is conciliatory, but he stands by his former criticisms." Contrary to Oberhelman \& Armstrong (1995, 252-253): "The answer to Horace's question is obvious: nothing was wrong with the res Lucilius chose, but rather Lucilius lacked real ingenium and therefore ars.” Oberhelman \& Armstrong do not discuss whether rerum dura (the harshness of his subject matter) may have had an influence. 
differently in Horace's own time. In the words of Gowers $(2012,330)$ "he would apply stricter Callimachean standards to his verse.” But, before I discuss lines 64-71, I will briefly look at the political context in which Lucilius worked.

Gaius Lucilius (180- ab.102 B.C.) was a Latin from Suessa Aurunca, an Oscan city near Campania, part of Latium novum. ${ }^{332}$ We saw already that he was a great-uncle to Pompey the Great (see at S.1.4.5) and belonged to a social class that was equivalent to the Roman equestrian order. It is known that some of his close relatives belonged to the Roman elite: a brother was a senator, whose daughter married Gnaeus Pompeius Strabo. Lucilius himself owned estates in Italy and Sicily (perhaps also in Sardinia); book III of his Satires, the Iter Siculum, described perhaps his journey to Southern Italy and Sicily to inspect his estates there. ${ }^{333}$ He lived the greater part of his life in Rome, although he probably never became a Roman citizen. In Rome he befriended some of the best-known philosophers of his age and he moved also in the best political circles. Scipio Aemilianus was a friend of his, whom he joined in 134 B.C. in the Numantine War in Spain. He returned probably in the next year to Rome, where by that time the unrest caused by the murder of the reformer Tiberius Gracchus, who as tribunus plebis (tribune of the people) started the programme of land re-distributions, was spreading. Lucilius completed in 131 B.C. his first books of Satires and he gave up writing in 105 B.C., three years before his death in Naples. According to Warmington (1967, xv),

the lifetime of Lucilius was the age which saw the spread of Rome's power over Greece, a steady increase of Greek influence in Italy, much inflow of wealth into Rome, the conquest of Spain, the destruction of Carthage, the stirring times of the Gracchi, the affair of Jugurtha, and the dangers of Cimbric and Teutonic invaders from the north.

During this period, Lucilius was heavily involved in writing about political issues. We saw already in section 2.1 (Introduction to the chapter) that Quintilian points out in Inst.10.1.94: nam et eruditio in eo mira et libertas atque inde acerbitas et abunde salis (for he [Lucilius] has an extraordinary learning and candor, and hence satirical severity and an abundance of wit). We also saw in the discussion of S.1.4.6-13 and parrhesia that Horace judges the work of Lucilius positively with respect to its critical spirit and candor. Thus, Lucilius censured freely many highly placed individuals of his time. To mention only a few: Q. Caecilius Metellus Macedonicus, censor in 131 B.C., his son C. Caecilius Metellus Caprarius, praetor in 116 B.C., L. Cornelius Lentulus Lupus, princeps senatus in 131-125 B.C., Q. Mucius Scaevola Augur, praetor in 121 or 120 B.C., L. Licinius Crassus, tribune in 107 B.C., Q. Granius, tribune in 107 B.C., L. Opimius, consul in 121 B.C., and others.

332 For Lucilius' life, see Fiske (1966, 64-68); Warmington (1967, ix - xx).

333 Lucilius' Iter Siculum is considered by Porphyrio (and followed by many scholars) the model of S.1.5, Horace's “Journey to Brundisium." I refer to my discussion of S.1.5 in section 2.2.3 and to note 178 , where I argue that it is unlikely that Horace emulated Lucilius. 
Warmington (1967, xix - xx) makes an interesting point in the final lines of his section about the life of Lucilius. He says

we see a man well acquainted with country-life, very fond of animals, particularly of horses and riding, who lived also in a big city and watched its society and politics. He seems to have been independent all his life, fond perhaps of leisure, at any rate disliking any kind of official position. ${ }^{334}$

It reads like an evaluation of Horace, the only difference being the harsh language of Lucilius compared to that of Horace. The latter recognized that the political context in which Lucilius worked was not all that dissimilar to that of his own age, that Lucilius' commentary on political and social issues was not dissimilar to his own ambition of becoming a political commentator, and that Lucilius kept his independence. In the lines that follow, Horace imagines how Lucilius would polish his style, if he were one of his contemporaries. S.1.10.64-71 reads:

\footnotetext{
fuerit Lucilius, inquam,

comis et urbanus, fuerit limatior idem

quam rudis et Graecis intacti carminis auctor,

quamque poetarum seniorum turba: sed ille,

si foret hoc nostrum fato dilatus in aevum,

detereret sibi multa, recideret omne quod ultra

perfectum traheretur, et in versu faciendo

saepe caput scaberet vivos et roderet unguis.

(granted, I say, Lucilius was obliging and had a sophisticated wit, granted, he was also more polished than an inexperienced originator of verse untouched by the Greeks was, and also than the crowd of older poets: still, if his life had been deferred by fate until our age, he would file away much, would keep cutting back all that stretched beyond the proper limit, and when he was shaping his verse he would often scratch his head and gnaw his nails to the quick)
}

Horace confirms in line S.1.10.65 again what he said about Lucilius in S.1.10.53, namely that Lucilius was comis (obliging). He paired this with the qualification urbanus praising Lucilius for his sophisticated wit. He used the same word in S.1.10.13-14, when he presented his view on the attributes of good poetry: interdum urbani, parcentis viribus atque/ extenuantis eas consulto (from time to time that of the sophisticated wit, who reserves and weakens the strength of his speech on purpose). We also saw that according to Gowers $(2012,326)$ S.1.10.42-43 shows that Pollio upheld Horace's criteria of urbanitas. Thus, comis et urbanus are two characteristics "that would admit Lucilius to H.[orace]'s literary coterie” (Gowers, 2012, 332). However, there is more to say about comis et urbanus. The words appeared already in S.1.4.90 in a negative context when Horace described the objectionable scandalmongering by the wrong type at the dinner party of the Roman patron. The man asperses everyone

334 Italics are mine. 
in every possible way. Typically nouveau riche, those at table consider the man (in S.1.4.90) agreeable (comis) and witty (urbanus). In this way, Horace referred to their reprehensible habit of parroting the value system and the social standards of the upper classes. He condemned the empty talk of the new rich, who did not sincerely attempt to adopt good standards of behaviour; standards which Horace considered indispensable in a civilized society and which he expected Lucilius to meet without difficulty.

Lucilius' personal qualities do not only meet Horace's standards, but we read in lines $65-67$ that he is also much more polished than expected. The traditional originators of new verse showed generally less refinement as they had not been immersed in the works of their Greek predecessors. Lucilius, however, was different as Horace already mentioned in S.1.4.1-2: Lucilius wholly depends on Eupolis and Cratinus and Aristophanes, true poets and the other men of principle of Old Comedy (EVPOLIS atque Cratinus Aristophanesque poetae,/ atque alii quorum comoedia prisca virorum est), and in S.1.4.6-7: Lucilius wholly depends on them, and them he followed changing only metre and rhythm (hinc omnis pendet Lucilius, hosce secutus/ mutatis tantum pedibus numerisque). Further, Lucilius is highly praised in lines 67-71, in which Horace says that, if Lucilius were still alive, he would be filing away much of his texts to the standards of good poetry, although scratching his head and gnawing his nails illustrate that he may have difficulty in doing. Thus, Horace expects that Lucilius could have met his standards of good poetry, in which brevitas (brevity), varietas (variety), and libertas (freedom of speech) were essential attributes. Summarizing Horace's opinion of Lucilius, I distinguish between Lucilius the literary and the political man. I interpret that Horace's opinion of Lucilius the literary man has developed in S.1 from one of rejection towards one of a fair degree of acceptance. Further, he expressed his respect for the political Lucilius. Horace may have concluded at this stage that the contemporary political circumstances were not very different from those in Lucilius' time: the land reforms started by the Gracchi and the unrest caused by the murder of the reformer Tiberius Gracchus giving rise to much social and political turmoil. Yet, Lucilius gave his commentary freely with great libertas setting an example that was very likely of great importance for Horace's own position. We saw in our discussion of S.1.4.5 and parrhesia that Lucilius was promoted as their man by the Republicans, who had adopted the position of being the defenders of free speech together with the hardline Stoics and the Pompeians. He was fostered as the defender of Republican libertas. Thus, Horace, the associate of Maecenas and Octavian, touched with a rejection of Lucilius upon a very sensitive political issue. Horace's lack of appreciation of Lucilius could well be taken as an attack on the traditional republican value of freedom of speech, coming from someone near Octavian. Moving towards an appreciation of Lucilius, the champion of libertas, would at least reduce the power of the Republicans' point, if not remove the claim. I sympathise much with DuQuesnay's (1984, 30-32) point that, although Horace distanced himself from Lucilian invective, it is feasible that he followed the same Lucilius as a model upholding the values of libertas. 
In the lines that follow, S.1.10.72-77, Horace gives his view on the kind of readership he rejects, and introduces the audience he prefers. I have already discussed in section 2.1 Horace's audience according to Gold's (1992, 161-175) classification. His view on the preferred audience cannot be severed from his objective writing $S .1$, the credentials for Maecenas. Yet, already at S.1.4.22-23 and S.1.4.71-74, and indeed at other occasions later in his career, he was very clear that he did not write for the large crowd (Ep.1.19.41-44 and Ars.212-213), and that he was not thrilled to see his poems as textbooks (Ep.1.20.1718, "the letter to his little book"). ${ }^{335}$ S.1.10.72-77 reads:

saepe stilum vertas, iterum quae digna legi sint

scripturus, neque te ut miretur turba labores,

contentus paucis lectoribus. an tua demens

vilibus in ludis dictari carmina malis?

non ego: nam satis est equitem mihi plaudere, ut audax

contemptis aliis explosa Arbuscula dixit.

(you must often cross things out, if you are to write what is worth a second reading, and you should not strive to get the admiration of the crowd, but that you be content with the select few as your readers. Or would you be so silly as to want your poems dictated in common elementary schools? Not me; just as unflinching Arbuscula, contemptuous of others, said when she was hissed of the stage: it is enough if the knights applaud me $)^{336}$

Arbuscula (lit: a small tree) was a famous mime actress, like Cytheris with whom Marc Antony had a love affair (see the discussion of S.1.2.55-63 and notes 95 and 97). Mime actresses were at the time favourite girl friends of upper class men. Arbuscula states that what counts in her case is the opinion of the knights, who are the upper class connoisseurs of women and also the men with superior taste in matters of the theatre. By analogy, Horace asserts in lines 76-77 that he is only interested in the opinion of his poetry held by "literary knights," the upper class connoisseurs and friends of poets and the men with superior taste in matters of the poetic. Horace's preference for small, select audiences happens to fit his programme of writing S.1, as his objective is to obtain a favourable judgement by Maecenas and those close associates, whom Maecenas is likely to choose for involvement in the process of assessing Horace's candidature for membership.

In the final passage, S.1.10.78-91, Horace gets very specific about the men with whom he wants to be associated. Wedged between a few poets he does not want to know, he presents a long list of colleague poets and some members of the political elite. He says in lines 78-80:

335 For Horace’s preferred audience, see also Weeda (2010, 47-48).

336 In line 72 saepe stilum vertas means literally: you must often turn your pen. One end of the stilus was pointed for writing and the other was flat for erasing. 
men moveat cimex Pantilius, aut cruciet quod vellicet absentem Demetrius, aut quod ineptus Fannius Hermogenis laedat conviva Tigelli?

(should the bed bug Pantilius bother me, or Demetrius torment me because he carps behind my back, or silly Fannius, the table companion to Tigellius Hermogenes, because he belittles me?)

According to Rudd $(2007,136)$ these lines are "a few expressions of genuine dislike. They are to be found for the most part in 1.10, where they centre on characters like Hermogenes, Demetrius, Pantilius and Fannius." 337 Rudd argues that the name of Pantilius, who cannot be identified, is something more than word-play by Horace:

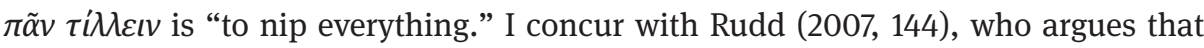
"the name is found in C.[orpus] I.[nscriptionum L.[atinarum]. X.5925 (Dess.6260), and it occurs here in a context full of personalities. The least we should assume is that Pantilius was a nickname for some carping critic of the day." ${ }^{338}$ Like Pantilius, Demetrius cannot be placed. Rudd $(2007,124)$ brackets him with Hermogenes, stating that they "were professionals who made their living by teaching and study." Both return in S.1.10.90-91 as teachers at a girls' school. Rudd also suggests that they probably resented Horace's friendship with Messalla, Pollio and Maecenas, and that they were likely politically hostile to Octavian. Fannius was mentioned by Horace already in S.1.4.21; he is identified by scholars either as a poet who wrote perhaps on themes of Stoic ethics, or as one of the brothers Fannii (see note 141). I concur with the view of Freudenburg $(1993,117)$ that the Fannius of S.1.4.21 and of S.1.10.80 are probably the same person, namely the poet. In S.1.4.21 he is depicted as a writer who promoted his own work to large audiences (the subject matter of the previous passage S.1.10.72-77), while the Fannius of S.1.10.80 is also one of many whom Horace mentions in the context of his detractors and friends: most of them are authors. Finally, it is useful to briefly review the history of Hermogenes, who figures prominently in S.1.10.18, 80 and 90, and who came on the scene for the first time in S.1.3.129 (see for details the discussion at S.1.10.17-19). According to Freudenburg (1993, 116), he was very able to "adjust himself to the changing political winds of the late Republic," and

337 White $(1993,38)$ also states "that Horace himself testifies repeatedly to the division and spite which prevailed in the lower echelons of his milieu," and he (1993, 38 note 8) argues that "the malice of companions is the leading theme of Serm.1.3 [especially lines 58-61], and the theme surfaces also at 1.4.78-103, [and at] 1.10.78-80." The passages in S.1.3 and S.1.4 deal indeed with the themes of relationships among companions, but, contrary to White I read a particular focus w.r.t. those relationships. In the passage in S.1.3, Horace describes the manner in which he wants to present himself among friends, that is taking the liberty to tell Maecenas whatever he thinks that the latter should know; the largeness of Maecenas shows in the way he handles the situation. In the passage in S.1.4, he states that friends should certainly frankly criticize each other if necessary, but this should not be done in a malicious manner, but in a civilized style.

338 I found the name Pantilius in Mommsen \& Henzen (1883, 721), Inscriptiones Latinae antiquissimae ad C. Caesaris mortem, IX. 91. 
DuQuesnay $(1984,56)$ considers the possibility that Hermogenes defected to Sextus Pompey. Horace refers in S.1.4.71-72 to disreputable poets selling their books in shops, where they are being soiled by the unreliable Hermogenes, whom he mentions in the same breath with the vulgar crowd. Finally, Hermogenes is referred to in S.1.9.25, where Horace quotes the pushy fellow: "invideat quod et Hermogenes ego canto" ("and my singing makes even Hermogenes envious”). The four men, Pantilius, Demetrius, Fannius and Hermogenes, have in common that they were all critical of Horace's poetry and of his political connection, although their criticism was presumably tinged with jealousy. Horace does not want to mix with them and they are most certainly no candidates for admission to the circle of Maecenas. He is not impressed by their attacks as long as he sees that men like Fuscus, Plotius, Varius, Maecenas, Virgil, Pollio, Messalla and others like his verses. ${ }^{339}$ The men who deserve such a place are addressed in the following passage S.1.10.81-90.

Plotius et Varius, Maecenas Vergiliusque,

Valgius, et probet haec Octavius, optimus atque

Fuscus, et haec utinam Viscorum laudet uterque!

ambitione relegata te dicere possum,

Pollio, te, Messalla, tuo cum fratre, simulque

vos, Bibule et Servi, simul his te, candide Furni,

compluris alios, doctos ego quos et amicos

prudens praetereo; quibus haec, sint qualiacumque,

arridere velim, doliturus si placeant spe

deterius nostra.

(Plotius and Varius, Maecenas and Virgil, Valgius and Octavius, and Fuscus, the best of men, may they approve of these [verses], and I wish that both Viscus brothers praise these! Without flattery I can mention you, Pollio, you Messalla, with your brother, and you too, Bibulus and Servius, and also with these you, fair Furnius, and several other intellectuals and friends, whom I discreetly do not mention. I should like these verses, whatever they are worth, be pleasing to them, and I shall be sorry if they are less agreeable than I hope)

339 Conform Harrison (2015, 41): "It has been well argued that within Satires 1 we find a kind of autobiographical progress of Horace from the excluded moralist of Satires 1.1-3 to the Maecenatic poet of 1.4 and beyond who has entered the literary establishment; [...] who in 1.10 takes his place amongst the leading writers of the day.” See also Zetzel (1980). Plotius is Plotius Tucca; Varius is L. Varius Rufus, epic poet, who together with Plotius Tucca later edited the Aeneis; C. Valgius Rufus, elegist; Octavius Musa, poet and historian; Aristius Fuscus (in S.1.10.83, in S.1.9.61, in Carm.1.22 ("Integer vitae") and in Ep.1.10). He was a dramatic writer and scholar and a good friend of Horace; Visci brothers, senators also mentioned in S.1.9.22; Pollio is C. Asinius Pollio, tragedian, orator, historian and general; Messalla is M. Valerius Messalla Corvinus, soldier, statesman and patron of among others Tibullus; Messalla's brother is L. Gellius Publicola, statesman and literary patron; L. Calpurnius Bibulus, stepson of Brutus; Servius, either an unknown erotic poet or a relative of Messalla; Furnius, probably an orator. See also Brown (2007, 192-193); Gowers (2012, 335-337); Harrison (2015, 41-43). The mention of Bibulus is important for the dating of the release of S.1. He was in Rome in 36/35 B.C. See DuQuesnay (1984, 20); Gowers (2012, 336). 
In this passage, Horace submits for approval his first book of sermones with his personal portrait and his views on a number of important matters to an impressive company of men. We have come full circle. The book in which Horace seeks to demonstrate that he can be a worthwhile member of the Roman intellectual elite begins with an address to Maecenas. The book closes with the names of fifteen men and many more whom he discreetly does not mention, who are his fellow intellectuals and friends. They are literary men, scholars and orators, and men in high public office and patrons of the arts. It looks that he attained his end.

Horace saved a final sneer for Demetrius (of line 79) and Hermogenes (here called Tigellius) wishing them good luck with their trivial pursuits which fit them better. According to Gowers $(2012,337)$ the two are "girls' tutors, i.e. second-class teachers. This desultory but snide picture of a pampered 'finishing school' may allude to the female readers of maudlin neoteric love elegy." Horace has done with them: they better "get lost." The final three lines of the book, S.1.10.90-92, read:

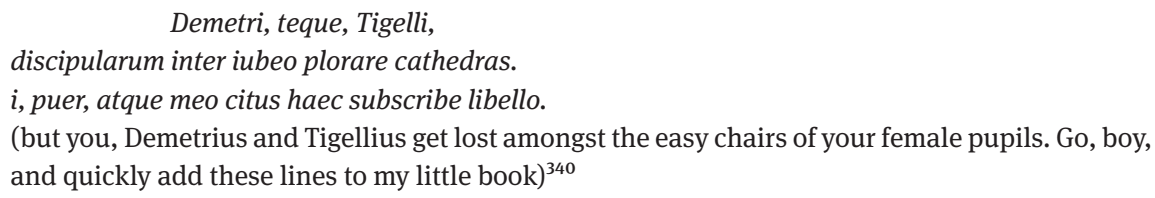

It is not absolutely clear whether the instruction to the slave-boy in the final line 92 refers to the scornful picture of Demetrius and Hermogenes or to the whole of S.1.10. I take it that the line refers to the whole poem as it reflects Horace's relief that writing S.1 delivered the result: he had been admitted to Maecenas' circle and the book should be distributed amongst the circle as soon as possible. ${ }^{341}$ One never knows whether people change their mind and therefore: hurry up and make hay while the sun shines.

340 I used Gowers' $(2012,337)$ rendering of iubeo plorare (get lost) in line 91.

341 Conform Brown (2007, 193-194): "the slave is instructed to append satire 10 to the other nine, so that the book can be published amongst the select audience just specified. citus [quickly] is not without irony, suggesting that, despite Horace's indifference to publicity and the need for slow, laborious composition, he is impatient to see the book published." 